UNIVERSIDADE DE BRASÍLIA - UNB

INSTITUTO DE GEOCIÊNCIAS - IGD

PROGRAMA DE PÓS-GRADUAÇÃO EM GEOLOGIA

ÁREA DE CONCENTRAÇÃO: MINERALOGIA E PETROLOGIA

\title{
Mineralogia e Petrologia do depósito hidrotermal de Vermiculita de São Luís de Montes Belos, Arco Magmático de Goiás.
}

Dissertação de Mestrado $n^{0} 373$

Hammel Assunção Oliver Macedo

Brasília 
UNIVERSIDADE DE BRASÍLIA - UNB

INSTITUTO DE GEOCIÊNCIAS - IGD

PROGRAMA DE PÓS-GRADUAÇÃO EM GEOLOGIA

ÁREA DE CONCENTRAÇÃO: MINERALOGIA E PETROLOGIA

\section{Mineralogia e Petrologia do depósito hidrotermal de Vermiculita de São Luís de Montes Belos, Arco Magmático de Goiás.}

Orientadora: Prof ${ }^{a}$. Dra. Maria Emilia S. Della Giustina (UnB)

Co-orientador: Prof. Dr. Claudinei Gouveia de Oliveira (UnB)

\section{Examinadores:}

Prof. Dr. Elton Luiz Dantas (UnB)

Prof $^{a}$. Dr. Reinaldo Santana Correia de Brito (UFBA)

\section{Brasília}


"Deus não escolhe os capacitados, mas capacita os escolhidos. Fazer ou não fazer algo só depende de nossa vontade e perseverança."

Autor desconhecido 
Agradecimentos

Agradeço a Deus por me fazer capaz de enfrentar cada obstáculo que houve em meu caminho;

Aos meus pais Oliver e Dinah e meus irmãos Brummel e Menndel, por todo apoio e incentivo que me deram;

À Universidade de Brasília (UnB) e ao programa de Pós-Graduação em Geologia (PPGG) pela infraestrutura disponibilizada para a realização da pesquisa;

À Coordenação de Aperfeiçoamento de Pessoal de Nível Superior (Capes) pela concessão da bolsa de estudo durante a realização deste trabalho;

Á Brasil Minérios S.A, por ter disponibilizado material e financiado atividades de campo, em especial ao geólogo Igor Fernandes Praxedes por toda ajuda prestada;

À minha orientadora, $\operatorname{prof}^{\mathrm{a}}$. Dr ${ }^{\mathrm{a}}$. Maria Emília Schutesky Della Giustina, por sua dedicação, disponibilidade, confiança e amizade;

Ao meu co-orientador prof. Dr. Claudinei Gouveia de Oliveira pela amizade e auxílio na realização desse trabalho;

Aos professores que de alguma forma contribuíram para a realização dessa pesquisa: Nílson Botelho, Mássimo Matteini, Natália Hauser, César Ferreira Filho, Roberta Vidotti, Edi Guimarães, Elton Dantas e Valmir Souza.

Aos colegas do laboratório de Microssonda Eletrônica Federico, Jacqueline e Pedro Alves;

Aos colegas geólogos, biólogos e técnicos do laboratório de Geocronologia Érico, Bárbara, Luciana, Matthew, Gilbésio e em especial ao amigo Felipe Valença por toda ajuda durante a minha carreira e também no tratamento dos dados;

Aos técnicos do laboratório de laminação Raimundo, Adalgisa, Edna e Francisca.

A equipe do laboratório de raio - x que me ajudou com algumas dúvidas.

Aos amigos e colegas Flávio Lima, Bernardo Filgueiras, Alanielson Ferreira (Alan), Renato, Cassia, Hudson, Davi Saldanha, Lili, Ítalo, Marcelo Teles, Thiago, Dudu, Isabela, Nívia, Felipe Ruiz, Citon, Grudka, Jéssica Maia, Stremel, Janice, Vitor (Abadá), Christian, Tosco, André, Anderson, Sílvia, Leonardo, David Vasconcelos, Dalila, Stephanie, Nícollas, Daniel e Sérgio que contribuíram com discussões, atividades de campo e em momento de distrações durante o período em que esse trabalho foi realizado.

Agradeço de forma muito especial a Karen Santos e Silva que contribuiu durante toda a minha pesquisa acompanhando durante várias horas de estudo, discutindo, revisando e acrescentando a minha pesquisa. 


\section{Índice}

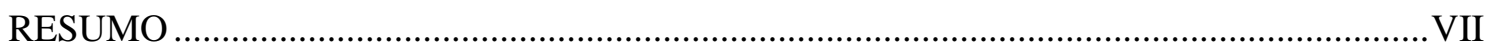

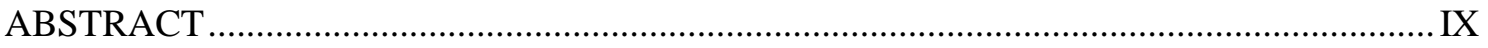

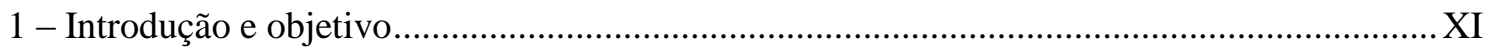

1.1 - Localização e vias de acesso ……………............................................................

1.2 - Contexto Geológico..................................................................................................

1.2.1 - Complexo Anápolis-Itauçu ................................................................................ XIII

1.2.2 - Arco Magmático Arenópolis (AMG) …………..................................................... XIII

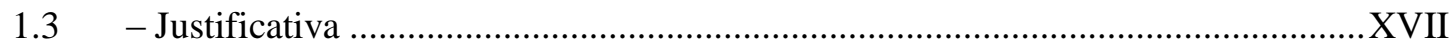

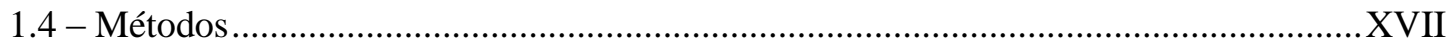

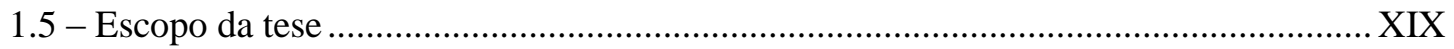

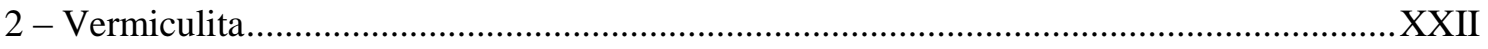

2.1 - Características cristalográficas ...............................................................................

2.2 - Ocorrências ……………………........................................................................ XXIII

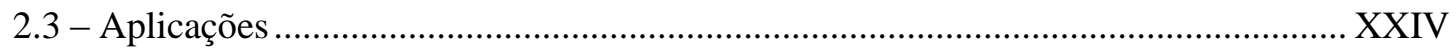

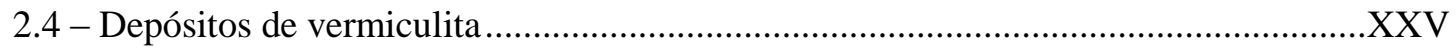

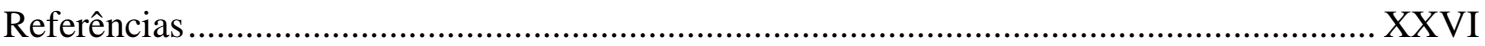

Mineralogy and Petrology of vermiculites hydrothermal deposit of São Luís de Montes Belos,

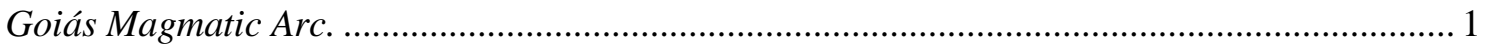

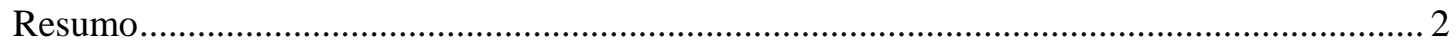

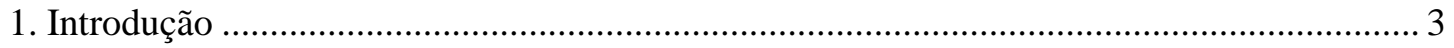

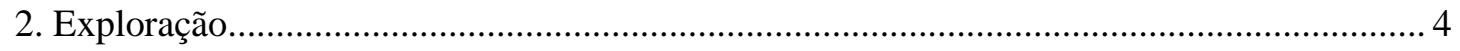

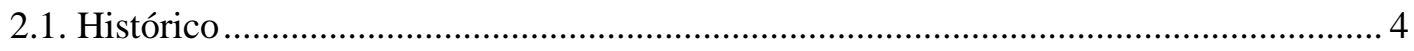

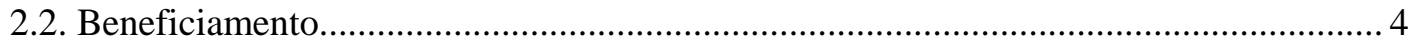

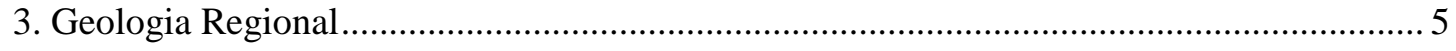

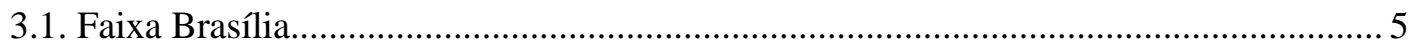

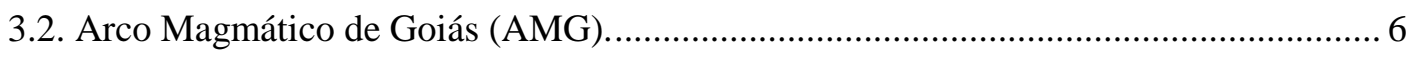

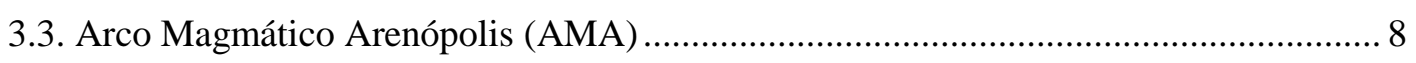

3.4. Geologia da região Mossâmedes - Moiporá .................................................................... 8

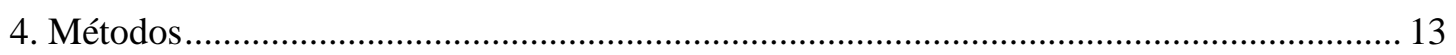

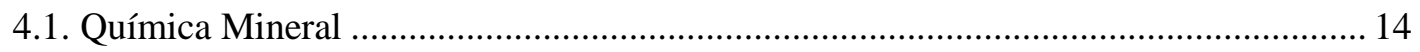

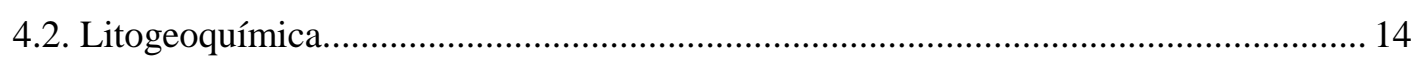

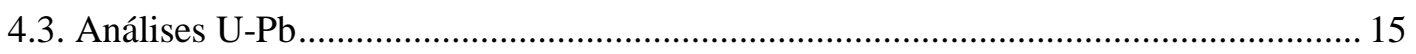

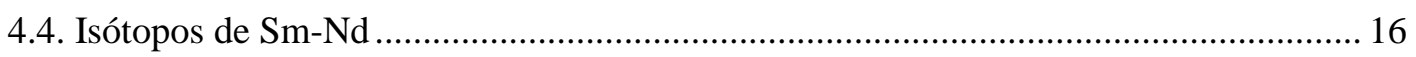

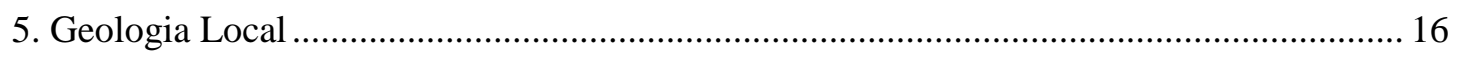

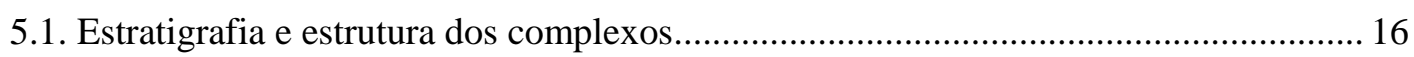




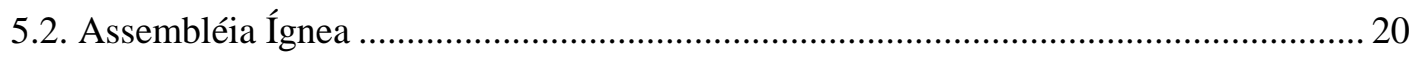

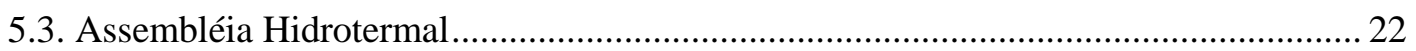

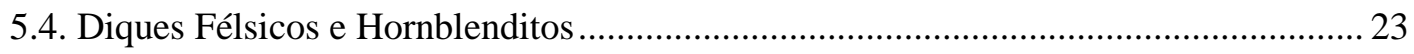

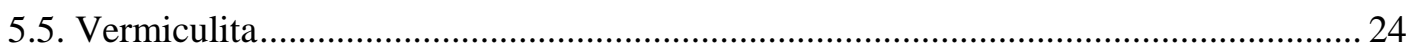

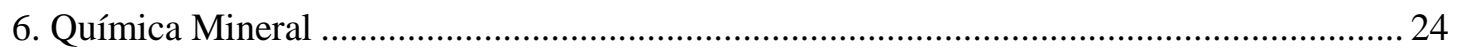

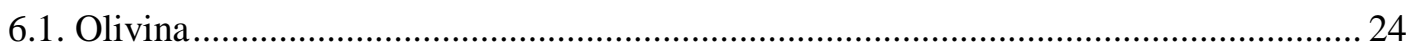

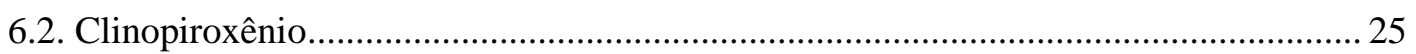

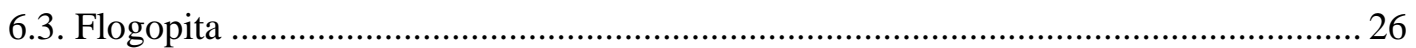

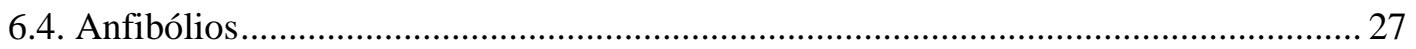

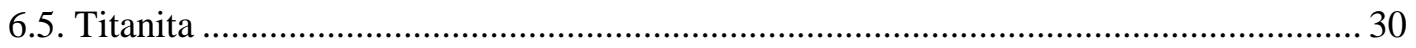

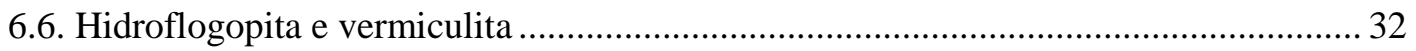

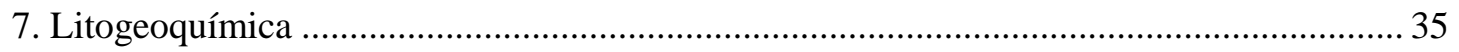

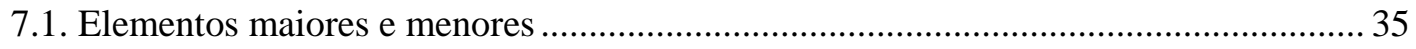

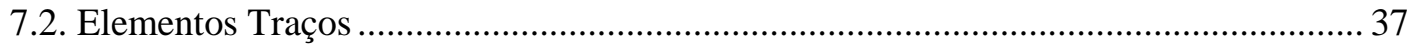

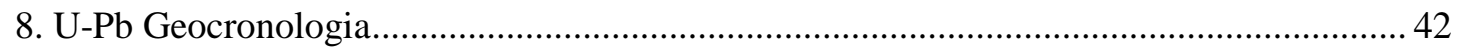

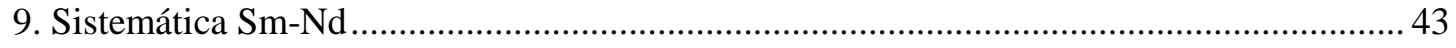

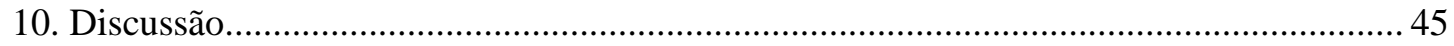

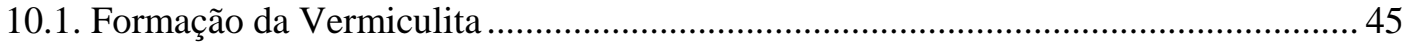

10.2. Processos de formação da SSLMB. ............................................................................ 47

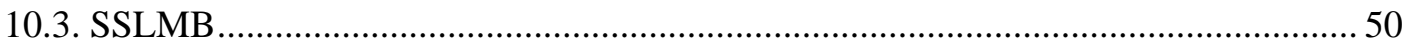

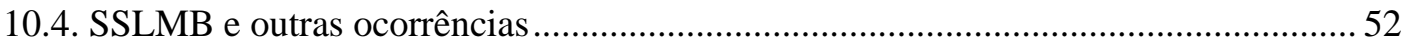

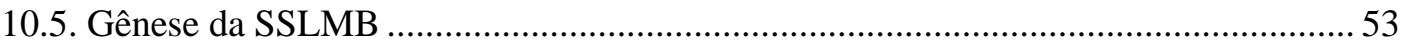

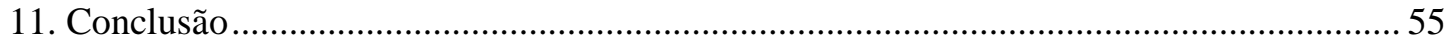

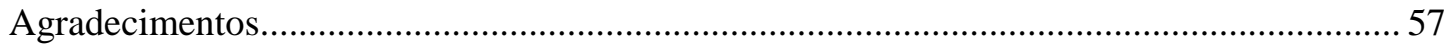

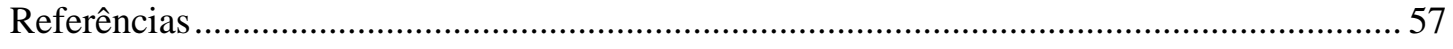

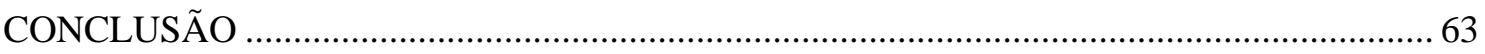

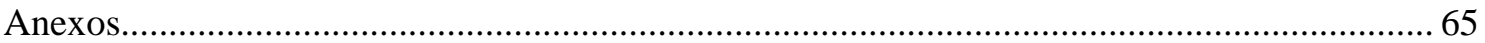




\section{Lista de Figuras}

Figura I - Localização e vias de acesso com destaque para área de estudo....... XII

Figura II - Mapa Geológico simplificado com ocorrências de corpos ultramáficos intrudidos no Complexo Itauçu e Arco Arenópolis. 1 - Americano do Brasil, 2 - Mangabal I e II, 3 - Água Fria, 4 - Andelândia, 5 - Fronteira Norte, 6 - Palmeiras, 7 - Mata Rica e Palmito, 8 Capelinha, 9 - Águas Claras, 10 - Taquaral, 11 - Santa Rosa, 12 Damolândia, 13 Goianira Trindade, 14 - Córrego Seco, 15 - Santa Bárbara e 16 - São Luís de Montes Belos. Modificado de Mota e Silva et. al. 2011)... XII

Figura III - Imagem Amplitude de Sinal Analítico contendo os corpos ultramáficos do Arco Arenópolis, com área de ocorrência dos corpos da suíte São Luís de Montes Belos destacado a esquerda. (modificado de Mota e Silva et.al. 2011) com parte da figura IV hachurada............XX

Figura IV - Imagem de Amplitude de sinal analítico com picos de anomalia magnética realçados da região de ocorrência dos corpos ultramáficos da Suíte São Luís de Montes Belos. Com corpos ultramáficos da SSLMB destacados. XX

Figura V - Estrutura cristalina da vermiculita (modificado de Vieira Coelho, 1986). T= tetraedro e $\mathrm{O}=$ octaedro XXII

Figura 1 - A) Província Tocantins, destaque para a Faixa Brasília B) Mapa geológico simplificado da Faixa Brasília (modificado de Pimentel et al., 2004; Fuck et. al., 2014 e

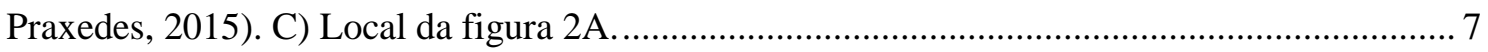
Figura 2 - A) Mapa Geológico da região Mossâmedes - Moiporá, envolvendo os principais corpos máfico-ultramáficos do AMA com unidades ortognáissicas e sequencias metavulcanossedimentares diferenciadas. (modificado de Lacerda et. al. 2000 e Motta de Araújo 2012). B) Imagem de Amplitude de Sinal Analítico com intrusões máfico - ultramáficas encaixadas no AMA e Complexo Anápolis Itauçú (Modificado de Mota e Silva 2011). C) Perfil geológico esquemático.

Figura 3 - Mapa geológico dos corpos Morro Pelado Norte, Morro Pelado Leste, Morro Pelado Sul e Leonel. 18

Figura 4 - A) Contato intrusivo entre vrm-flogopititito e encaixante, com destaque para intrusão pegmatítica horizontal e hornblenditos vertical (MPL). B) Furos de sondagem de biotitahornblenda ortognaisse pertencente à unidade ortognáissica de Sanclerlândia, com foliação variando de pronunciada a suave. C) Amostra de clinopiroxenito com zona de flogopitito associada (FS 123-100.19) e amostra com intercalação entre wehrlito e clinopiroxenito fino (FS 123-93.95) (MPN). D) Frente de lavra com camada de srp-mt-flogopitito sotoposta por camada de clinopiroxenito, com ocorrência de domínio com ovoides entre as camadas. Destaque para hornblendito na porção superior à direita (MPS). E) Destaque para interface de reação entre pegmatito quartzo-feldspático encaixado em vrm-flogopitito, onde as lamelas de vermiculita e flogopita que bordejam o corpo félsico possuem orientação preferencial, enquanto que as lamelas da encaixante não possuem orientação (MPL). F) Destaque para três tipos de zona de alteração entre veio quartzo-feldspático e srp-mt-vrm-flogopititito. A zona I consiste de cristais prismáticos de antofilita, a zona II é composta somente por flogopita e vermiculita e na zona III ocorrem feldspato e quartzo de granulação média a grossa, com lamelas de flogopita e vermiculita disseminadas (MPN). F) Plano E-W com sigmoide de clinopiroxenito (CPX) 
incluso em flogopitito, mostrando sentido de cisalhamento sinistral (MPL). Abreviação mineral segundo Whitney e Evans (2010)...

Figura 5 - A) Fotomicrografia a nicóis paralelos (NP) de dunito serpentinizado, com relictos de olivina parcialmente alterados para serpentina e magnetita (Am11). B) Fotomicrografia a nicóis cruzados (NX) da amostra FS123-93.95, com destaque para borda do grão de diopsídio alterado para tremolita. C) Fotomicrografia (NX) da amostra FS123-93.95, com destaque para o contato retilíneo entre olivina e flogopita zonada com inclusões de ilmenita (sagenítica) no núcleo e borda da lamela sem inclusões. Destaque também para borda da flogopita alterando para vermiculita. D) e E) Fotomicrografia (NP) e imagem de BSE, respectivamente, com destaque para processo de alteração de clinopiroxênio para tremolita e neoformação de flogopita, titanita e plagioclásio (FS17-28,65m). F) Fotomicrografia (NX) de pseudomorfo de olivina com núcleo substituído por iddingsita e corona de lamelas de serpentina em meio a uma matriz composta por hidroflogopita (FS100). G) Fotomicrografia (NX) de cristais prismáticos de tremolita, com alteração para talco, cercada de vermiculita e flogopita. Fotomicrografia pertencente à parte de ovoide que ocorre na zona entre rochas peridotíticas e piroxeníticas (Am 17d). H) Grãos de hornblenda e flogopita orientados em dique ultramáfico (Am20) (NP). Abreviação mineral segundo Whitney e Evans (2010).

Figura 6 - A) Srp-mt-vrm-flogopitito com pseudomorfos de olivina totalmente substituídos por iddingsita em meio a uma matriz de hidroflogopita azul-prateada. B) Fotomicrografia (NX) da amostra de wehrlito, com destaque para a lamela de flogopita alterada para vermiculita (FS101). Pontos 1, 2 e 3 referem a análises feitas por microssonda eletrônica FS101-III CIV_1, FS101-III CIV_2 e FS101-III CIV_3, respectivamente. Área da figura 18 destacada. C) Destaque para reação entre grãos de magnetita e lamelas de vermiculita/flogopita com grande quantidade de inclusões de ilmenita (NP). D) Vermiculita de cor bronze em vrm-flogopitito. Abreviação

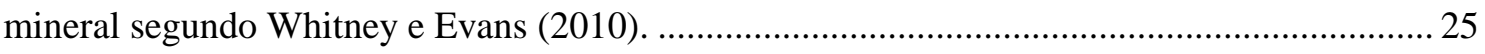
Figura 7 - Conteúdo de $\mathrm{CaO}, \mathrm{TiO}_{2}$ e $\mathrm{Cr}_{2} \mathrm{O}_{3}$ em diopsídio nas rochas ultramáficas da SSLMB.. 28 Figura 8 - A) e B) Teores de $\mathrm{FeO}+\mathrm{Fe}_{2} \mathrm{O}_{3}$ em função de $\mathrm{MgO}$ e $\mathrm{TiO}_{2}$ e C) $\mathrm{Al}_{2} \mathrm{O}_{3}$ em em função de $\mathrm{FeO}+\mathrm{Fe}_{2} \mathrm{O}_{3}$ das lamelas de flogopita. D) Relação de $\mathrm{Fe}, \mathrm{Al}^{\mathrm{VI}}$, $\mathrm{Ti}$ e $\mathrm{Mg}$ das lamelas de

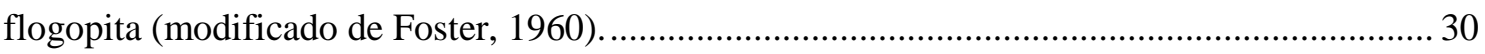
Figura 9 - Diagramas $\mathrm{Na}_{2} \mathrm{O}$ (wt\%) por $\mathrm{Al}_{2} \mathrm{O}_{3}$ (wt\%) dos anfibólios pertencentes aos corpos

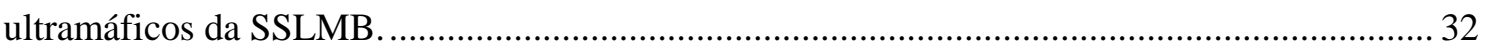

Figura 10 - Relação das concentrações de $\mathrm{Fe}^{2+}(\mathrm{apfu})$ e $\mathrm{TiO}_{2}$ (wt\%) por $\mathrm{K}_{2} \mathrm{O}$ (wt\%) dos hornblenditos, wehrlitos, srp-mt-vrm-flogopititos, clinopiroxenitos e vrm-flogopititos. ............ 33 Figura 11 - Diagrama com teores de $\mathrm{Cr}_{2} \mathrm{O}_{3}$ (wt \%) em função de $\mathrm{Al}_{2} \mathrm{O}_{3}$ (wt $\%$ ) e $\mathrm{Fe}_{2} \mathrm{O}_{3}$ (wt\%) dos

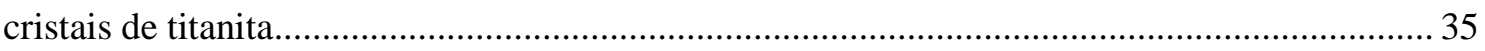

Figura 12 - A) B) e C) Diagramas $\mathrm{MgO}$ por $\mathrm{Al}_{2} \mathrm{O}_{3}$, ternário $\mathrm{MgO}, \mathrm{Al}_{2} \mathrm{O}_{3}$ e $\mathrm{FeO}+\mathrm{Fe}_{2} \mathrm{O}_{3}$ e $\mathrm{SiO}_{2}$ por TiO2 distinguindo dois tipos de população e comparado a lamelas de flogopita de srp-mtvrm - flogopitito e vrm - flogopitito. Abreviação mineral segundo Whitney e Evans (2010). ... 37 Figura 13 - Variação de $\mathrm{K}_{2} \mathrm{O}, \mathrm{Al}_{2} \mathrm{O}_{3}, \mathrm{MgO}, \mathrm{CaO}, \mathrm{TiO}_{2}, \mathrm{Cr}_{2} \mathrm{O}_{3}$, Ni e $\mathrm{Ba}$ ao longo do furo FS90. Abreviação mineral segundo Whitney e Evans (2010).......................................................... 40 Figura 14 - Elementos terras raras normalizado ao Condrito para as amostras da SSLMB. A) Dunito, wehrlito e clinopiroxenito comparados aos valores das rochas ultramáficas do Complexo Americano do Brasil (ABC) (Mota e Silva et al., 2011). B) Srp-mt-vrm-flogopitito e Vrm-flogopitito e C) hornblendito. Normalizado pelos valores de Sun e McDonough (1989). . 41 Figura 15 - Elementos-traço normalizados ao Condrito (Sun e McDonough, 1989).para A) Wehrlito e Clinopiroxenito comparados com os valores de ABC (Mota e Silva et al., 2011). B) Srp-mt-vrm-flogopitito e vrm-flogopitito e C) Hornbledito. ...................................................... 42 Figura 16 - Diagrama U-Pb Tera-Wasserburg (1972) dos grãos de titanita da amostra Am 31. O intercepto inferior corresponde à idade do hidrotermalismo, enquanto que o intercepto superior de não tem significado geológico. 
Figura 17 - $\varepsilon N d$ em função do $\mathrm{T}(\mathrm{Ga})$ com as concentrações isotópicas das rochas da SSLMB e rocha encaixante. Os dados da composição isotópica de $\varepsilon N d$ do AMG foram retirados de Pimentel e Fuck (1992) e Laux et al., 2005. Os teores da composição isotópica dos complexos máfico-ultramáficos (MUM) Americano do Brasil Complex (ABC), Santa Bárbara Complex (SBC) e Córrego Seco (CS) foram retirados de Gioia, (1997), Nilson et al., (1997) e Laux et al., (2004). 46

Figura 18 - A) Imagem BSE de detalhe da figura 6C com flogopita alterando para vermiculita e exsolução de ilmenita. B) Relação dos valores de $\mathrm{MgO}, \mathrm{K}_{2} \mathrm{O}$ e $\mathrm{H}_{2} \mathrm{O}$ dos pontos das figuras $6 \mathrm{C}$ e $18 \mathrm{~A}$.

Figura 19 - Evolução esquemática dos corpos da SSLMB e ação dos fluidos magmático hidrotermais. Abreviação mineral segundo Whitney e Evans (2010). 50 Figura 20 - Tabela com as assembleias paragenéticas de cada estágio da SSLMB, tempo de intrusões dos diques e possíveis reações de transformação para alguns minerais formados durante o hidrotermalismo e intemperismo. 51

Figura 21 - A) e B) Colisão final e fechamento da Faixa Brasília, nessa porção da Faixa Brasília com formação do Complexo Americano do Brasil e os granitos da Suíte Aragoiânia. C) Hidratação e metassomatismo da cunha mantélica para formação da SSLMB no bloco Sanclerlândia e início da formação de granitoides no bloco Novo Brasil. Detalhe para as litologias dos blocos Novo Brasil e Turvânia possuíre $\varepsilon N d$ positivo e rochas do bloco Sanclerlândia possuírem $\varepsilon \mathrm{Nd}$ negativo. D) Extenção litosférica e interação do manto astenosférico e litosferérico gerando os fluidos para cristalizar hornblenditos, diques e veios quartzo-feldspáticos que intrudem a SSLMB. Modelo esquemático para formação dos corpos da SSLMB e intrusão dos diques félsicos e hornblenditos (modificado de Davies e von Blanckenburg, 1995) SLMBS = São Luís de Montes Belos Suite; AGS = Aragoiânia Suite; SNS = Serra Negra Suite; SLMB SZ= São Luís de Montes Belos Shear Zone; MNB SZ= Moiporá Novo Brasil Shear Zone. 


\section{Índice de Tabelas}

Tabela I - Sumário de idades das rochas do Arco Magmático Arenópolis e máfico-ultramáficas do Complexo Anápolis-Itauçu. 1 - Pimentel et al., 1991; 2 - Pimentel e Fuck, 1994; 3 Pimentel et al., 1996; 4 - Gioia, 1997; 5 - Nilson et al., 1997; 6 - Pimentel et al., 2003; 7 Laux et al., 2004; 8 - Laux et al., 2005; 9 - Della Giustina et al., 2011; 10 - Guimarães et al., 2012; 11 - Motta de Araújo, 2012; 12 - Marques et al., 2016. UO = Unidade Ortognáissica, SMVS = Sequencia Metavulcanossedimentar, SA = Suíte Aragoiânia e SSN = Suíte granítica Serra Negra, MUM = Máfico-Ultramáfico. XXI

Tabela 1 - Sumário de idades das rochas do Arco Magmático 1 - Pimentel et al., 1991; 2 Pimentel e Fuck, 1994; 3 - Pimentel et al., 1996; 4 - Gioia, 1997; 5 - Nilson et al., 1997; 6 Pimentel et al., 2003; 7 - Laux et al., 2004; 8 - Laux et al., 2005; 9 - Guimarães et al., 2012; 10 - Motta de Araújo, 2012; 11 - Marques et al., 2016. OU = Unidade Ortognaissica (Ortogneiss Unit), MVSS = Sequencia Metavulcanossedimentar (Metavulcano Sedimentary Sequence), MUM = Máfico - Ultramáfico, AGS = Suíte Aragoiânia (Aragoiânia Suite) e SNS = Suíte granítica Serra Negra (Serra Negra Suite).

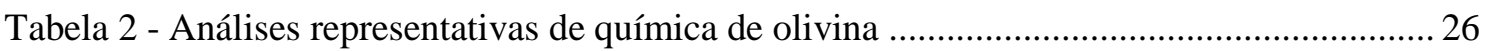

Tabela 3 - Dados representativos de clinopiroxênio. Abreviação mineral segundo Whitney e

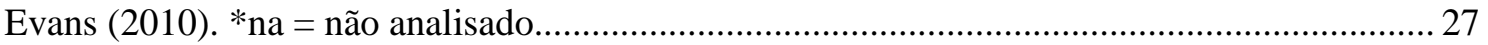

Tabela 4 - Dados representativos de química de flogopita. Abreviação mineral segundo Whitney e Evans (2010)

Tabela 5 - Análises representativas dos anfibólios da SSLMB. Abreviação Mineral segundo Whitney e Evans (2010). *na = não analisado.

Tabela 6 - Dados representativos de química de titanita. Abreviação mineral segundo Whitney e Evans (2010).

Tabela 7 - Dados representativos de hidroflogopita e vermiculita. H2O-** água na estrutura e H2O+*água entre as camadas. Abreviação mineral segundo Whitney e Evans (2010)... 36 Tabela 8 - Análise de elementos maiores, menores e traços das rochas da SSLMB. As razões estão normalizadas ao condrito de Sun e McDonough (1989). *na = Não analisado. 38 Tabela 9 - Dados geocronológicos de U-Pb em cristais de titanita. Para o cálculo das razões foram utilizados o padrão GJ1. 


\section{RESUMO}

A Suíte São Luís de Montes Belos (SSLMB) é constituída por um conjunto de intrusões ultramáficas, afetadas por processos hidrotermais, mineralizadas a dois tipos de vermiculita. Os corpos estão alojados na unidade ortognáissica Sanclerlândia (822 Ma), Arco Magmático Arenópolis (AMA), porção sudoeste da Faixa Brasília. Mais de quarenta corpos ultramáficos de formato elíptico, intrusivos e dispostos ao longo das direções NE-SW e N-S, compõem a SSLMB. Embora os processos hidrotermais sejam amplamente distribuídos, ocorrem zonas menos alteradas com rochas ígneas parcialmente preservadas, possibilitando a distinção de uma estratigrafia ígnea com camadas intercaladas de peridotitos e de clinopiroxenitos. A paragênese ígnea é constituída por olivina $\left(\mathrm{Fo}_{87}\right)$ + diopsídio + flogopita tipo I nos peridotitos e diopsídio + flogopita nos clinopiroxenitos. Hidroflogopita I (flogopita I + vermiculita I), tremolita, serpentina e magnetita constituem a paragênese hidrotermal do serpentina - magnetita vermiculita - flogopitito (srp-mt-vrm - flogopitito), produto de alteração do peridotito. $\mathrm{O}$ equivalente hidrotermal do clinopiroxenito é o vermiculita - flogopitito (vrm flogopitito) com paragênese constituída por flogopita tipo II, actinolita, tremolita e titanita. Os corpos da SSLMB são intrudidos por hornblenditos, diques pegmatíticos quartzo-feldspáticos, hornblenditos e veios feldspáticos. Os hornblenditos são constituídos por hornblenda (70 - 90\% do volume), flogopita tipo III, titanita e flúorapatita. Os diques félsicos são constituídos por albita $\left(\mathrm{Ab}_{90}\right)$, quartzo, sanidina $\left(\mathrm{Or}_{83}\right)$ e turmalina. Os veios possuem feldspatos de mesma composição dos diques félsicos. As intrusões pegmatíticas félsicas resultam em diferentes interfaces de reação nos diferentes corpos. Quando inseridas em meio à peridotitos e seus derivados hidrotermais, produzem três zonas de alteração: (i) zona da antofilita; (ii) zona da hidroflogopita I; e (iii) zona da hidroflogopita I, quartzo e feldspato. Em clinopiroxenitos e vrm - flogopititos, as intrusões félsicas produzem uma borda de reação com lamelas de flogopita II e vermiculita II orientadas. A vermiculita ocorre disseminada em srp-mt-vrm - flogopititos, vrm - flogopititos e nas bordas dos diques pegmatíticos. $\mathrm{O}$ argilomineral foi gerado principalmente durante o intemperismo, porém o processo de vermiculitização da flogopita do tipo I iniciou no final do evento hidrotermal. Datação U-Pb em titanita associada à alteração de diopsídio em vrmflogopititos forneceu uma idade de $556 \mathrm{Ma}$, interpretada como a idade do início do processo de transformação de vermiculita I a partir de flogopita I. Padrão enriquecido de 
elementos terras raras (ETR) em relação ao condrito e valores negativos de $\varepsilon_{\mathrm{Nd}}(-3,2$ a 5,2), são típicos de intrusão ultramáfica em crosta continental espessa. Apesar da idade dos corpos da SSLMB ser desconhecida, a ausência de deformação e metamorfismo regional sugere que essas intrusões são posteriores à colisão final e fechamento da Faixa Brasília. A química de rocha total e os valores de $\varepsilon_{\mathrm{Nd}}$, sugerem que essas rochas são derivadas do manto metassmatizado, em um ambiente envolvendo subducção de placa, com magmatismo gerado a partir da hidratação e metassomatismo da cunha mantélica. No AMA as unidades supracrustais (890 - 574 Ma) e ortognáissicas (899 - 630 Ma) são justapostas por zonas de cisalhamento transcorrentes com direções NNE a NNW. Alguma dessas estruturas podem ter controlado a disposição dos corpos SSLMB e a percolação dos fluidos hidrotermais, enriquecidos em potássio, responsáveis pela alteração de peridotitos e clinopiroxenitos. 


\begin{abstract}
The São Luís de Montes Belos Suite (SLMBS) consists of a group of ultramafic intrusions that hosts important vermiculite deposits. The SLMBS crops out at the southwestern-most part of the Brasília Fold Belt within the Sanclerlândia orthogneissic unit in the Arenópolis Magmatic Arc (AMA). The SLMBS is composed of more than forty elliptical-shaped intrusive bodies distributed along the NE-SW and $\mathrm{N}-\mathrm{S}$ trends. Although affected by hydrothermal processes, primary mineralogy and texture are still partially preserved, allowing the distinction of a layered sequence with alternating peridotites and clinopyroxenites layers, characterized by olivine $\left(\mathrm{Fo}_{87}\right)+$ diopside+phlogopite type I and diopside+phlogopite type II, respectively. The mineral paragenesis of serpentinte - magnetite - vermiculite - phlogopitite (srp-mt-vrm phlogopitite), peridotites hydrothermal product, consits of hydrophlogopite I (phlogopite I + vermiculite I), tremolite, serpentine and magnetite. The mineral paragenisis of vermiculite - phlogopitite (vrm - phlogopitite), clinopyroxenites hydrothermal product, consist of phlogopite type II, actinolite, tremolite and titanite. Hornblendite and felsic pegmatitic dykes and veins cross cut the SLMBS bodies. Hornblendites are composed by hornblende (70 - 90\% v.), phlogopite, titanite and fluorapatite. Felsic dykes contains albite $\left(\mathrm{Ab}_{90}\right)$, quartz, sanidine $\left(\mathrm{Or}_{83}\right)$ and tourmaline, and result in different mineralogical assemblages at the interface with ultramafic rocks, forming three distinguishable zones within peridotite: (i) anthophyllite zone; (ii) hydrophlogopite I zone; (iii) hydrophlogopiteI+quartz+feldspar zone. In clinopyroxenites, oriented lamellae of flogopita II and vermiculite II are formed at the contact with felsic dykes. Vermiculite occurs as disseminated grains in peridotite and clinopyroxenite alteration products (srp-mt-vrm phlogopitite and vrm phlogopitite), respectively, and and at the contact between the pegmatitic dyke and the host rock.. The vermiculite mineral deposit was mainly formed by weathering, but there is textural evidence that at least part of the vermiculitization process of phlogopite I initiated during the hydrothermal imprint. U-Pb LA-MC-ICPMS dating of titanite from a vrm phlogopitite provided an age of 556 $\pm 19 \mathrm{Ma}$, interpreted as representative of the timing of hydrothermal imprint on the SLMBS suit. However, although the SLMBS emplacement age is unknown, the absence of deformation and regional metamorphism suggests that these intrusions are later to the final stages to the final ocean closure and
\end{abstract}


continental colision of Brasília Belt. Combined whole rock litogeochemistry and Sm-Nd systematics values indicates these rocks were derived from metasomatized mantle partial melting in a scenario involving final orogen relaxation. The AMA supracrustal (890 - $574 \mathrm{Ma})$ and orthogneissic (899 - $630 \mathrm{Ma})$ units are juxtaposed to each other along NNE to NNW stike-slip zones. Some of those structures may have controlled the disposition of SLMBS bodies and the percolation of potassium-enriched hydrothermal fluids, responsible for the alteration of peridotites and clinopyroxenites. 


\section{1 - Introdução e objetivo}

Os corpos máfico-ultramáficos na região sul do estado de Goiás, importantes fontes de minério como de $\mathrm{Cu}, \mathrm{Co}, \mathrm{Ni}, \mathrm{Fe}$, Ti e $\mathrm{V}$, são explorados desde a sua descoberta em 1969 por um trabalho de mapeamento geológico da Universidade de Brasília (Dani et al. 1973). Apesar das atividades de extração de minério na maioria desses corpos, apenas alguns envolvem um estudo geológico detalhado, como os complexos Americano do Brasil, Mangabal e Santa Bárbara (Candia, 1983; Mota e Silva et al., 2011.; Nilson et al., 1986; 1997; Silva, 1991). Os demais, como os corpos localizados entre as cidades de Sanclerlândia e São Luís de Montes Belos, foram pouco estudados.

Os corpos da região de São Luís de Montes Belos são mineralizados a vermiculita, com dois tipos de ocorrência deste mineral, identificados em estudos realizados por Silva (2006). Os processos que acarretaram na formação deste filossilicato é uma questão bastante discutida no meio científico (Basset, 1963; De la Calle e Suquet, 1988; Hindman, 1992; entre outros), com reciclagem constante na literatura.

A presente dissertação consiste na caracterização em detalhe dos corpos ultramáficos da região de São Luís de Montes Belos e processos hidrotermais aos quais estes corpos foram submetidos, por meio de petrografia, geoquímica e geocronologia. A tese de mestrado está inserida no projeto "Petrologia e Geocronologia de complexos máficos-ultramáficos acamadados do Arco Magmático de Goiás Meridional e implicações para a evolução da Faixa Brasília" aprovado no edital MCTI/CNPQ/Universal 14/2014 - Faixa B.

\section{1 - Localização e vias de acesso}

A área do projeto está inserida na porção centro-oeste do estado de Goiás, próximo à cidade de São Luís de Montes Belos, localizado a $280 \mathrm{~km}$ a sudeste de Brasília. As principais vias de acesso são BR060, BR070 e GO164 (Fig. I). No contexto geológico se insere no Arco Magmático Arenópolis (AMA), porção sul do Arco Magmático de Goiás (AMG), oeste da Faixa Brasília (Fig. 1 do artigo em anexo). 


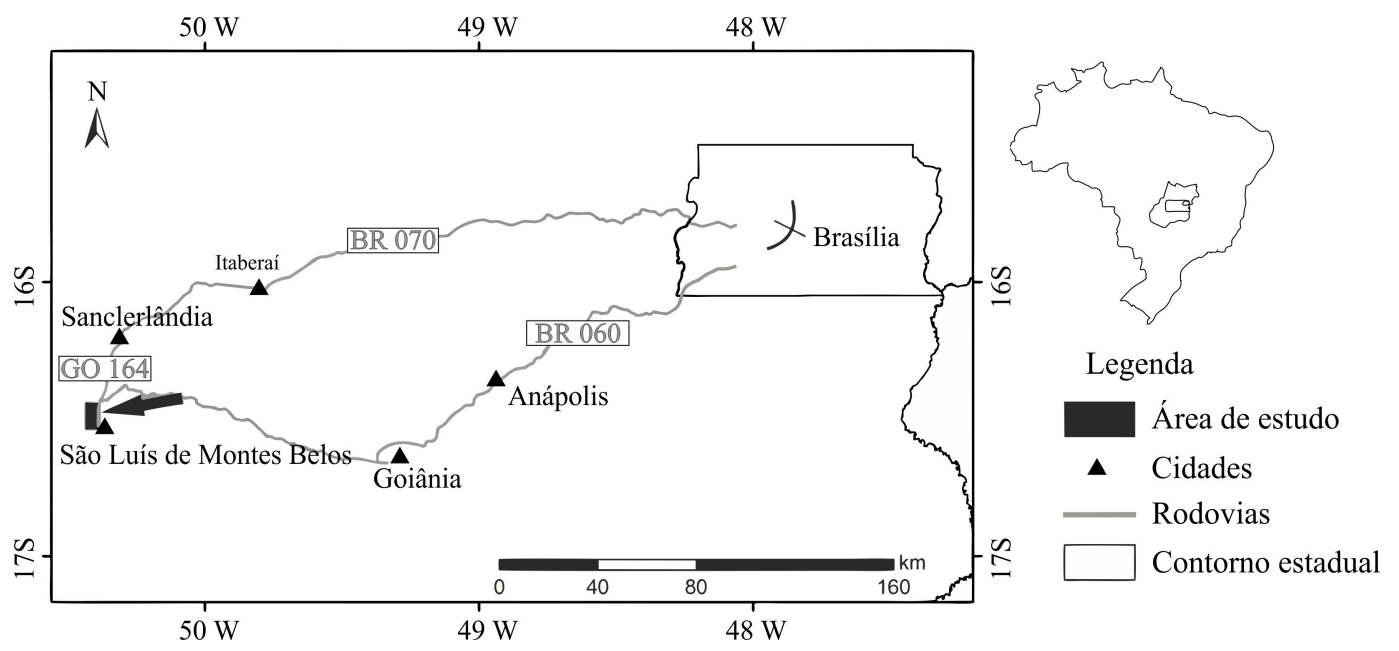

Figura I - Localização e vias de acesso, com destaque para área de estudo.

\section{2 - Contexto Geológico}

As intrusões máfico-ultramáficas na porção sul da Faixa Brasília ocorrem alojadas no Complexo Anápolis-Itauçu e no Arco Magmático Arenópolis com os principais corpos destacados na figura II.

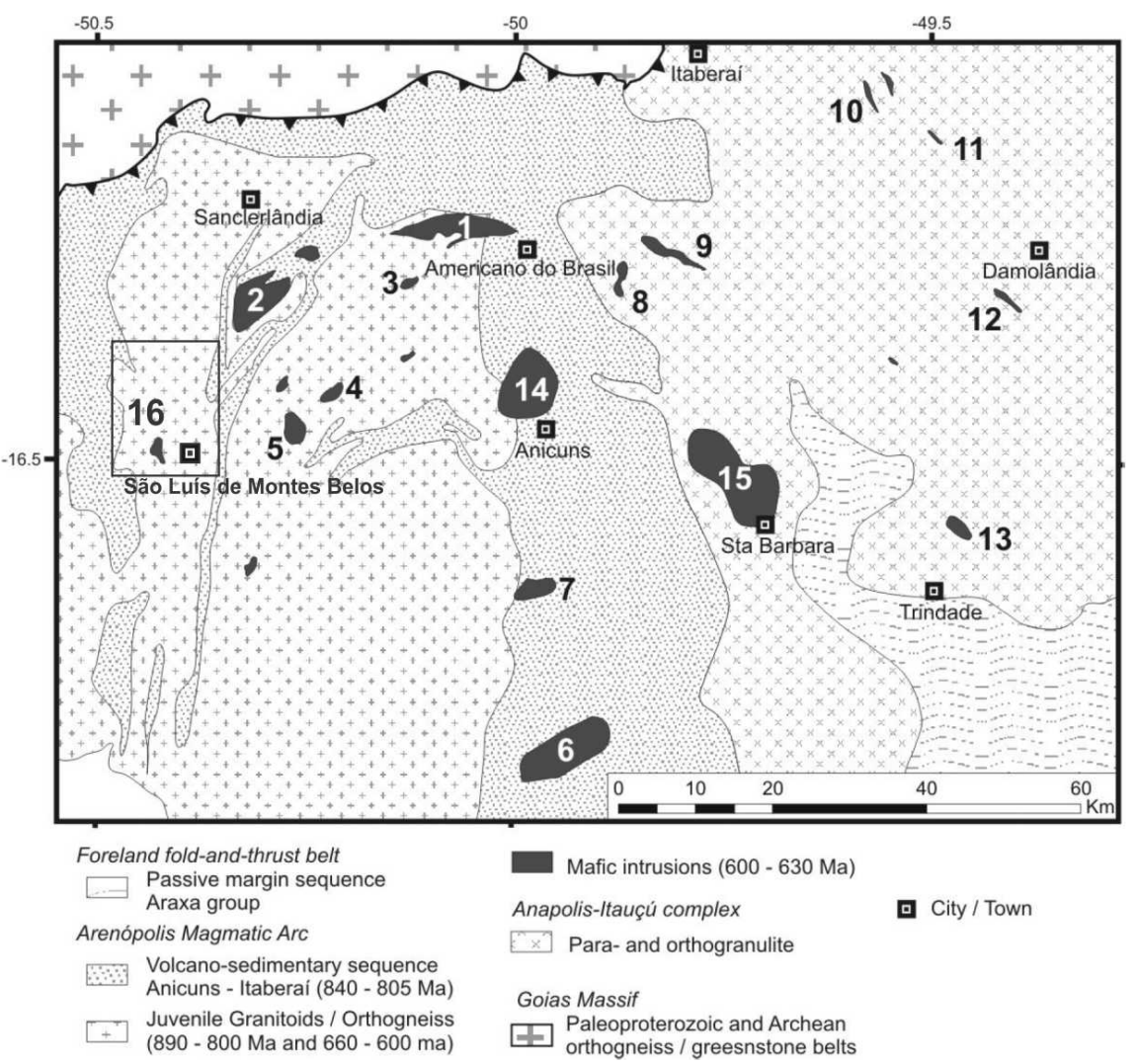

Figura II - Mapa Geológico simplificado com ocorrências de corpos ultramáficos intrudidos no Complexo AnápolisItauçu e Arco Arenópolis. 1 - Americano do Brasil, 2 - Mangabal I e II, 3 - Água Fria, 4 - Andelândia, 5 - Fronteira Norte, 6 - Palmeiras, 7 - Mata Rica e Palmito, 8 - Capelinha, 9 - Águas Claras, 10 - Taquaral, 11 - Santa Rosa, 12 Damolândia, 13 - Goianira - Trindade, 14 - Córrego Seco, 15 - Santa Bárbara e 16 - São Luís de Montes Belos. Modificado de Mota e Silva et. al., 2011). 


\subsection{1 - Complexo Anápolis-Itauçu}

O Complexo Anápolis-Itauçu está inserido na Zona Alóctone Interna da Faixa Brasília, a leste do Arco de Arenópolis, compreendendo ortogranulitos, paragranulitos, complexos máfico-ultramáficos acamadados e granitos. As rochas estão expostas em meio a rochas metassedimentares do grupo Araxá, com idades variando entre 760 e 650 Ma e pico metamórfico entre 680 e 670 Ma (Della Giustina et al., 2011).

Os ortogranulitos são representados por gnaisses tonalíticos a granodioríticos, granulitos dioríticos/gabróicos e complexos máfico - ultramáficos. Intrusões máficoultramáficas acamadadas pertencentes aos complexos máfico - ultramáficos ocorrem como corpos alongados segundo NW-SE, paralelos às estruturas regionais do Complexo Anápolis-Itauçu. Exemplos são os corpos de Goianira-Trindade, Águas Claras, Taquaral, Serra do Gongomé e Damolândia.

Os paragranulitos são representados por granulitos aluminosos com concentrações variáveis de granada, silimanita, espinélio, cordierita e feldspato, rochas cálcio-silicáticas, mármores e quartizitos. Assembleias minerais de ultra-alta temperatura (safirina + quartzo, ortopiroxênio + sillimanita + quartzo, wollastonita + escapolita e hercinita + quartzo) foram identificadas em algumas localidades e acusaram temperaturas superiores a $1100^{\circ} \mathrm{C}$, a pressões moderadas ( 10 kbar; Baldwin et al., 2005; Moraes et al., 2002, 2007).

Os complexos máfico-ultramáficos Taquaral e Damolândia constituem de noritos, gabronoritos, piroxenitos e peridotitos (principalmente harzburgitos), com textura ígnea totalmente substituída em algumas porções pelo metamorfismo e tectonismo ocorrido na região (Della Giustina et al., 2011).

\subsection{2 - Arco Magmático Arenópolis (AMG)}

O AMG é formado por unidades supracrustais e ortognáissicas, as quais constituem uma crosta continental juvenil de idade Neoproterozoica dispostas ao longo de faixas com direções NNE, a norte, e NNW, a sul (Fig.1 no artigo em anexo). Na porção setentrional, Arco Magmático Mara Rosa, a ocorrência de rochas metassedimentares detríticas (quartzitos e granada-feldspato mica xisto) são mais abundantes em relação à porção Meridional, no Arco Magmático Arenópolis (AMA), embora com menor conteúdo de rochas vulcânicas. O metamorfismo se deu em dois momentos distintos, o mais antigo entre 760 e 730 Ma (Junges et al., 2002) e o mais 
novo entre 610 e 604 Ma (Pimentel et al., 2001) O primeiro evento, em fácies metamórfico anfibolito, está relacionado à acreção de arco de ilhas, e o evento mais novo, em fácies xisto verde, está relacionado à colisão final e fechamento da bacia entre os crátons Amazônico e São Francisco no final do Ciclo Orogênico Brasiliano (Junges et al., 2002).

O AMA é composto por unidades ortognáissicas e rochas supracrustais justapostas ao longo de zonas de cisalhamento com direções NNE e NNW, pertencentes ao Lineamento Transbrasiliano. Também ocorrem intrusões máfico-ultramáficas e granitos alcalinos pós- a tardi-orogênicos ricos em potássio, de idades entre o Neoproterozoico e início do Paleozoico (Pimentel et al., 2000).

\section{$\underline{\text { Ortognaisses }}$}

Os ortognaisses possuem composição variando de cálcica a cálcio-alcalina, consistindo de metatonalitos, metadioritos e metagranitoides com ocorrência de biotita e hornblenda. Estas unidades possuem assembleia mineral metamórfica característica de fácies anfibolito, com texturas e estruturas ígneas preservadas em algumas porções (Pimentel e Fuck, 1992; Lacerda Filho et al., 1999; Pimentel et al., 2000). Isótopos de $\mathrm{U} / \mathrm{Pb}, \mathrm{Rb} / \mathrm{Sr}$ e $\mathrm{Sm} / \mathrm{Nd}$ indicam idades de cristalização entre 906 e $625 \mathrm{Ma}$, com três eventos principais.

O primeiro evento de cristalização compreende os gnaisses Arenópolis com idade U-Pb de $899 \pm 7$ Ma (Pimentel et al., 1991; Pimentel e Fuck, 1994), Sanclerlândia com idade U-Pb de $822 \pm 7$ Ma (Motta de Araújo 2012) e Rb-Sr em rocha total de 940 Ma (Pimentel e Fuck 1994) e Iporá com idade U-Pb de 804 × 6 Ma (Laux et al., 2005). Tais rochas apresentam valores positivos de $\varepsilon_{\mathrm{Nd}}$ que variam de $+0,3 \mathrm{a}+3,2$, sugerindo manto primitivo. A concentração de elementos maiores indicam protólitos com altos teores de $\mathrm{CaO}, \mathrm{MgO}, \mathrm{P}_{2} \mathrm{O}_{3}$ e $\mathrm{Al}_{2} \mathrm{O}_{3}$ e concentrações de elementos menores comparáveis a granitoides primitivos do tipo M (Pimentel et al., 1991).

O segundo evento é representado apenas por gnaisses milonitizados e granitoides do tipo TTG na região de Jaupaci. Os milonitos são compostos pelas unidades granito-gnáissicas Creoulus e Lavrinha de idades $784 \pm 14 \mathrm{Ma}$ e $748 \pm 4 \mathrm{Ma}$, respectivamente (Laux et al.,. 2005). Na região de Jaupaci, ocorrem dois tipos de metagranitoides: (i) ilmenita-metagranitoides intensamente foliados, com composição variando de tonalito a granodiorito e idade U-Pb em zircão de $770 \pm 8 \mathrm{Ma}$ (Marques et al., 2016); (ii) magnetita-metagranitoides intensamente foliados com porções 
milonitizadas, apresentando composição de trondhjemito a granito e idade U-Pb de 753 \pm 12 (Marques et al., 2016).

O terceiro evento de cristalização dos gnaisses do AMA é representado por metagranitoides com idade $\mathrm{U} / \mathrm{Pb}$ de $669 \pm 3 \mathrm{Ma}$ da unidade gnáissica Matrinxã e hornblenda-biotita gnaisses das unidades ortognáissicas Choupana (662 $\pm 12 \mathrm{Ma})$ e Palminópolis-Turvânia-Firminópolis com idades U-Pb entre 625 e 647 Ma (Laux et al., 2005).

\section{$\underline{\text { Supracrustais }}$}

As sequências metavulcanossedimentares (898-743 Ma) possuem composição predominantemente máfico-ultramáfica toleítica na base, passando na porção superior a um pacote de rochas vulcânicas intermediárias a ácidas de natureza calci-alcalina, associadas a tufos e frequentemente intercaladas com rochas metassedimentares. $\mathrm{O}$ contato destas sequências com as encaixantes é geralmente feito por meio de falhas, onde as rochas foram afetadas por cisalhamento dúctil-rúptil com alteração hidrotermal associada (Baêta Júnior e Moreton, 1999).

A sequência Arenópolis $(890 \pm 8 \mathrm{Ma})$ é formada pelas unidades Córrego do Santo Antônio e Córrego da Onça, separadas por gnaisses com idade modelo $\mathrm{T}_{\mathrm{DM}}$ arqueana. A unidade Córrego do Santo Antônio é composta por metassedimentos e rochas calci-silicáticas associadas a corpos máfico-ultramáficos intrusivas. A unidade Córrego da Onça é dominada por metavulcânicas cálcio-alcalinas derivadas de um magma muito primitivo, com valores de $\varepsilon_{\mathrm{Nd}}$ entre +2.5 e +2.8 e idade de recristalização por titanita de 594 Ma (Pimentel et al., 1991, Pimentel e Fuck, 1992).

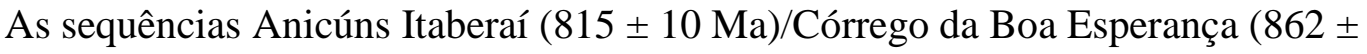
$5 \mathrm{Ma}$ ) são compostas por duas unidades: unidade metavulcânica máfico-ultramáfica, formada por epidoto-anfibolitos, granada anfibolitos, biotita-clorita xistos, sericitaquartzo-clorita xistos, talco-clorita xistos, epidoto-clorita-muscovita-quartzo-hornblenda xistos, tremolita-actinolita xistos, clorititos e talco-clorita-antofilita xistos; e unidade metassedimentar, que consiste de granada-mica xistos feldspáticos, cianita-quartzo xistos, sericita-clorita-quartzo xistos, quartzitos micáceos metassedimentos sílticoargilosos, quartzitos ferruginosos, quartzitos manganesíferos, mármores calcíticos, metacherts e grafita xistos (Baêta Júnior e Moreton, 1999; Nunes 1990; Laux et al., 2004).

A sequência Bom Jardim é constituída por rochas metavulcânicas e metassedimentares. As metavulcânicas ocorrem associadas a rochas subvulcânicas com 
composição variando de toleítica a riolítica, metamorfisadas em fácies xisto verde a anfibolito. Em algumas porções encontram-se tufos isentos de evento deformacional ou de alteração, preservando textura e composição reliquiar ígnea. Grãos de zircão retirados de metavulcânica ácida obteve idade U-Pb de $749 \pm 6$ (Guimarães 2012, Pimentel e Fuck, 1986; Seer, 1985).

Iporá-Amorinópolis (636 $\pm 6 \mathrm{Ma})$ consiste de metavulcânicas e metassedimentares com idade modelo $\mathrm{T}_{\mathrm{DM}}$ entre 0.9 e $1.1 \mathrm{Ga}, \varepsilon_{\mathrm{Nd}}$ entre +0.3 e +5 e idade de recristalização de $600 \pm 31$ Ma pelo método $\mathrm{Rb}-\mathrm{Sr}$ em rocha total (Amaro 1989; Pimentel et al., 1991; Pimentel e Fuck, 1994).

A sequência Jaupaci é composta por basaltos e riolitos metamorfisados intercalados com metavulcânicas ácidas (dacitos e riolitos), depositados no intervalo entre $764 \pm 14$ Ma (Pimentel et al., 1991), obtido por U-Pb em metariolito e $574 \pm 10$ Ma (Marques et al., 2016) obtido por U-Pb em grãos de zircão das rochas metavulcânicas ácidas.

\section{Intrusões sin a pós-colisionais}

O final do evento Brasiliano/Pan-Africano foi responsável pelo alojamento de inúmeros corpos tonalíticos, granodioríticos, graníticos e de corpos máfico-ultramáficos distribuídos ao longo do Arco Magmático Arenópolis e Complexo Anápolis-Itauçu, devido a uma intensa atividade ígnea e tectônica (Pimentel et al., 2004).

O magmatismo que gerou os corpos máfico-ultramáficos gerou uma série de intrusões acamadadas (Figs. II, III e IV), com composição variando de máficaanortosítica (Córrego Seco e Santa Bárbara), máfica - ultramáfica (Americano do Brasil, Mangabal I e II, Água Fria, Andelândia, Fronteira Norte, Palmeiras, Mata Rica e Palmito) a ultramáfica (São Luís de Montes Belos), de leste para oeste, respectivamente, no AMA.

O complexo Córrego Seco compreende gabro, diorito e anfibolito com idade U$\mathrm{Pb}$ em zircão de $622 \pm 6 \mathrm{Ma}$. As rochas desse complexo foram geradas a partir de magma derivado do manto depletado, com valor de $\varepsilon_{\mathrm{Nd}}$ de +1.8 (Laux et al., 2004; Nunes, 1990).

O complexo gabro-anortosítico acamadado Santa Bárbara é constituído por noritos, gabronoritos, anortositos e gabros metamorfisados em fácies anfibolito. Unidade ultramáficas (metapiroxenitos) ocorrem como lentes associadas à metagabros e não apresenta correlação genética com o corpo gabro-anortosítico. Grãos de zircão obtidos em anortositos forneceram uma idade U-Pb de $598 \pm 8 \mathrm{Ma}$ (Laux et al., 2004). 
As rochas deste complexo são derivadas de um magma parental basáltico toleítico com alta concentração de alumínio (Silva, 1991).

O Complexo Americano do Brasil é formado por corpos máfico-ultramáficos mineralizados em sulfetos de níquel e cobre (pirrotita, pirita e pentlandita). A estruturação dos corpos consiste de camadas de peridotito intercalada com camadas de gabronorito, cortados por veios de hornblenda diorito e granodiorito pegmatítico (Nilson et al., 1986; Mota e Silva et al., 2011). Análises obtidas por U-Pb em grãos de zircão do peridotito acusaram idade de cristalização de $628 \pm 8$ Ma (Laux et al., 2004).

Mangabal I e II são corpos máfico-ultramáficos estratiformes, compostos por peridotitos, gabronoritos, harzburgitos e piroxenitos metamorfisados em fácies anfibolito. Algumas porções possuem paragênese e textura ígneas preservadas (Cândia, 1983). Análises geocronológicas pelo método K-Ar acusaram idade de resfriamento de $612 \pm 8$ Ma (Gioia, 1997).

Próximo à cidade de São Luís de Montes Belos, Goiás, ocorre dezenas de intrusões acamadadas (Figs. IV e 2, no artigo em anexo) compostas somente por rochas ultramáficas (peridotitos e clinopiroxenitos), influenciadas por processos hidrotermais e de intemperismo Esses corpos são mineralizados a dois tipos de vermiculita associadas aos peridotitos e clinopiroxenitos (Silva, 2006).

\section{$\underline{\text { Intrusões de granitos cálcio-alcalinos }}$}

Uma série de intrusões tardi- a pós-tectônicas de granitos cálcio-alcalinos ricos em potássio e pequenos corpos dioríticos, a maior parte isenta de deformação, ocorrem ao longo do AMA (Pimentel et al., 2004). A intrusão desses granitos ocorreu entre 620 e 485 Ma e possuem assinaturas do tipo I e A (Pimentel et al., 2000).

Em resumo, o magmatismo no AMA foi contínuo entre 900 e $485 \mathrm{Ma}$, com quatro eventos principais, sumarizados na Tabela I.

\section{3 - Justificativa}

Alguns autores correlacionam os corpos máfico-ultramáfico intruditos no complexo Anápolis - Itauçú e no AMA, porém estes possuem características distintas como idades de intrusão e metamorfismo distintas, entre 680 e 670 Ma (Della Giustina et al., 2011) e entre 626 e $596 \mathrm{Ma}$ (Laux et al., 2004), respectivamente. 
$\mathrm{Na}$ literatura todos os corpos máfico-ultramáficos intrudidos no AMA estão inseridos na Suíte Máfico-Ultramáfica Americano do Brasil (Figs. II e III), porém os alguns corpos possuem características muito distintas. Nos corpos a leste (Córrego Seco e Santa Bárbara), predominam gabros e anortositos, derivados de um magmatismo máfico e metamorfisados em fácies anfibolito. Os corpos ao centro (Americano do Brasil e Mangabal) são compostos por rochas deformadas com composição variando de dunito a granodiorito, derivados de um magmatismo máfico-ultramáfico e metamorfisadas em fácies xisto-verde a anfibolito. Os corpos a oeste, próximos à cidade São Luís de Montes Belos, são compostos apenas por rochas ultramáficas não afetadas por metamorfismo regional que afetaram os demais corpos, porém influenciadas por hidrotermalismo. As características dos corpos da Suíte Máfico-Ultramáfica Americano do Brasil são suficientes para definir pelo menos três pulsos máfico-ultramáficos: um pulso mais básico (corpos próximo à cidade de São Luís de Montes), intermediário (Americano do Brasil e Mangabal) e menos básico (Córrego Seco e Santa Bárbara).

A maioria dos corpos máfico-ultramáficos hospedados no AMA e Complexo Anápolis - Itauçu possuem grandes dimensões (5 a 20 km de extensão) (Figs. II e III) quando comparado à forma de ocorrência dos corpos próxima a cidade de São Luís de Montes Belos (doravante o conjunto desses corpos será chamado de Suíte São Luís de Montes Belos - SSLMB). A SSLMB é constituída por dezenas de corpos com proporções pequenas (300 e $1200 \mathrm{~m}$ de extensão) (Fig. IV).

O tipo de mineralização que ocorre na SSLMB é distinto dos demais corpos máfico-ultramáficos. A SSLMB é mineralizada a vermiculita, gerada a partir de flogopita. Grande parte das lamelas flogopita é produto de hidrotermalismo que pode estar relacionado ao evento de potassificação que gerou os granitos alcalinos no AMA.

Este trabalho tem como objetivo caracterizar os processos hidrotermais que influenciaram os corpos dessa suíte por dados petrográficos e químicos. Além disso, aspectos petrogenéticos e geocronológicos serão utilizados na comparação entre a SSLMB e as demais ocorrências máfico - ultramáficas intrudidos no AMA.

\section{4 - Métodos}

A tese de dissertação consiste de: (i) na revisão bibliográfica dos estudos realizados no Arco Magmático de Goiás; (ii) tipos de depósito com vermiculita associada; (ii) processos de formação da vermiculita; (iv) interpretação de dados obtidos 
a partir de trabalhos de campo; (v) extensa análise petrográfica de detalhe e (vi) dados de geoquímica de rocha total e (vii) dados isotópicos e geocronológicos.

O registro dos corpos ultramáficos em mapa de detalhe (1:50000) foi executado pela Brasil Minérios S.A. (2001 a 2013). O trabalho de campo foi desenvolvido em Julho de 2013 em conjunto com a equipe da Brasil Minérios S.A. e a caracterização dos processos geológicos aos quais os corpos foram submetidos foi realizada a partir das descrições de cava, de furos de sonda, de trinta e oito lâminas delgadas e análises de química mineral e geoquímica de rocha total.

Dezenove lâminas delgadas, envolvendo rochas variavelmente alteradas pelos processos hidrotermais, veios de tremolita e hornblendito foram analisadas em Microssonda Eletrônica modelo JEOL JXA-8230 (para mais detalhes, vide tópico 4.1 do artigo). Os minerais selecionados correspondem a flogopita (Mg-biotita), vermiculita, anfibólios, clinopiroxênios, olivina, titanita, feldspatos, e magnetita.

As análises de geoquímica mineral foram realizadas em 3 amostras de afloramentos e 6 amostras de furo de sonda nos laboratórios Bureau Veritas Mineral (Canadá) e SGS Geosol LTDA (Brasil). As descrições dos métodos aplicados para obtenção de elementos maiores e menores estão descritas no tópico 4.2 do artigo em anexo.

Os resultados isotópicos de $\mathrm{U}-\mathrm{Pb}$ em titanita e a sistemática $\mathrm{Sm}-\mathrm{Nd}$ foram obtidos pelo Laboratório de Geocronologia do Instituto de Geociências (IG) da Universidade de Brasília. As descrições dos métodos para obtenção dos dados estão descritas em detalhe nos itens 4.3 e 4.4 do artigo em anexo.

\section{5 - Escopo da tese}

A tese contém dois capítulos introdutórios com o objetivo de informar quanto à justificativa do tema (capítulo 1) e sobre as características da vermiculita (capítulo 2). O resultado da dissertação está disponibilizado na forma de artigo intitulado "Characterization of hydrothermal and metassomatic processes in the ultramafic bodies of São Luís de Montes Belos Suite, Goiás, Brazil”, a ser submetido à revista Ore Geology Reviews. 


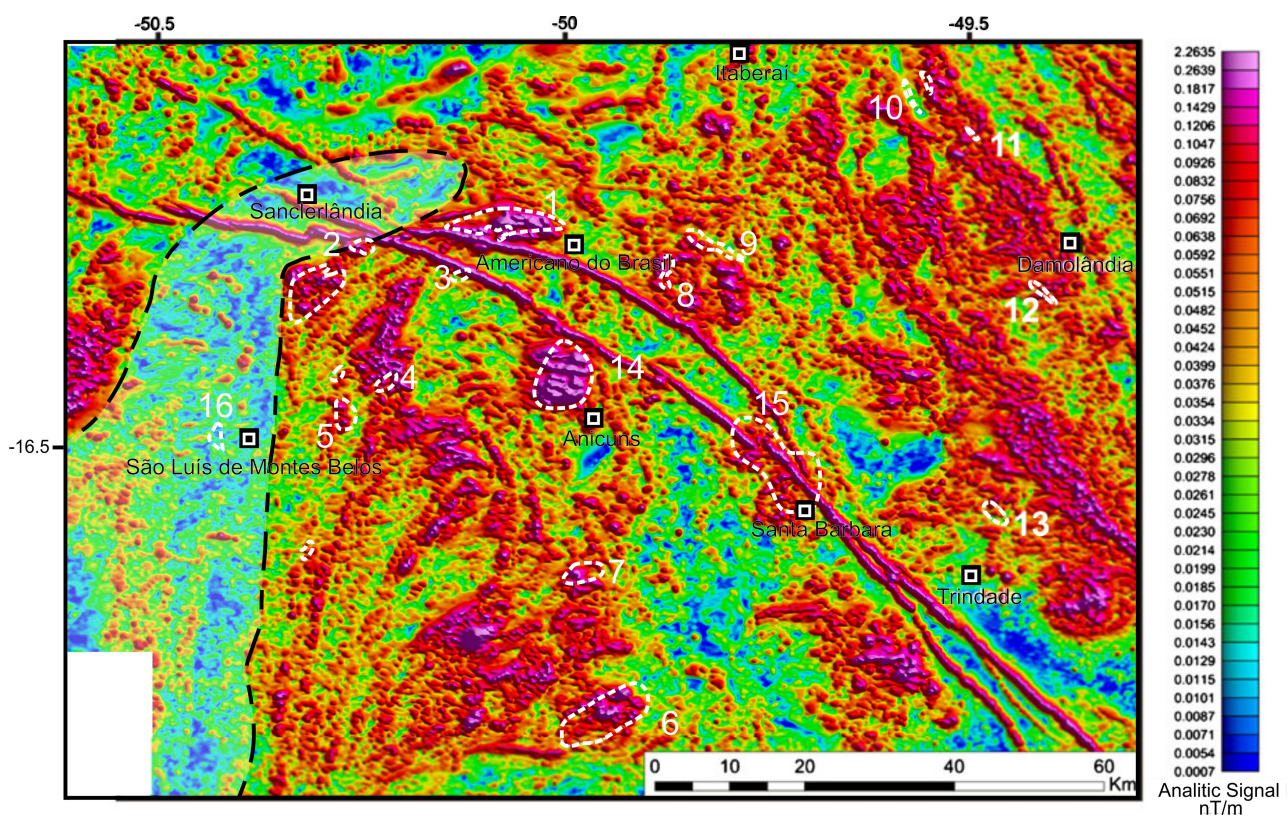

Figura III - Imagem de Amplitude do Sinal Analítico contendo os corpos máfico - ultramáficos do Arco Arenópolis e Anápolis Itauçu, com área de ocorrência dos corpos da suíte São Luís de Montes Belos destacado a esquerda (modificado de Mota e Silva et.al. 2011). Parte da porção hachurada astá detalhada na Fig. IV.

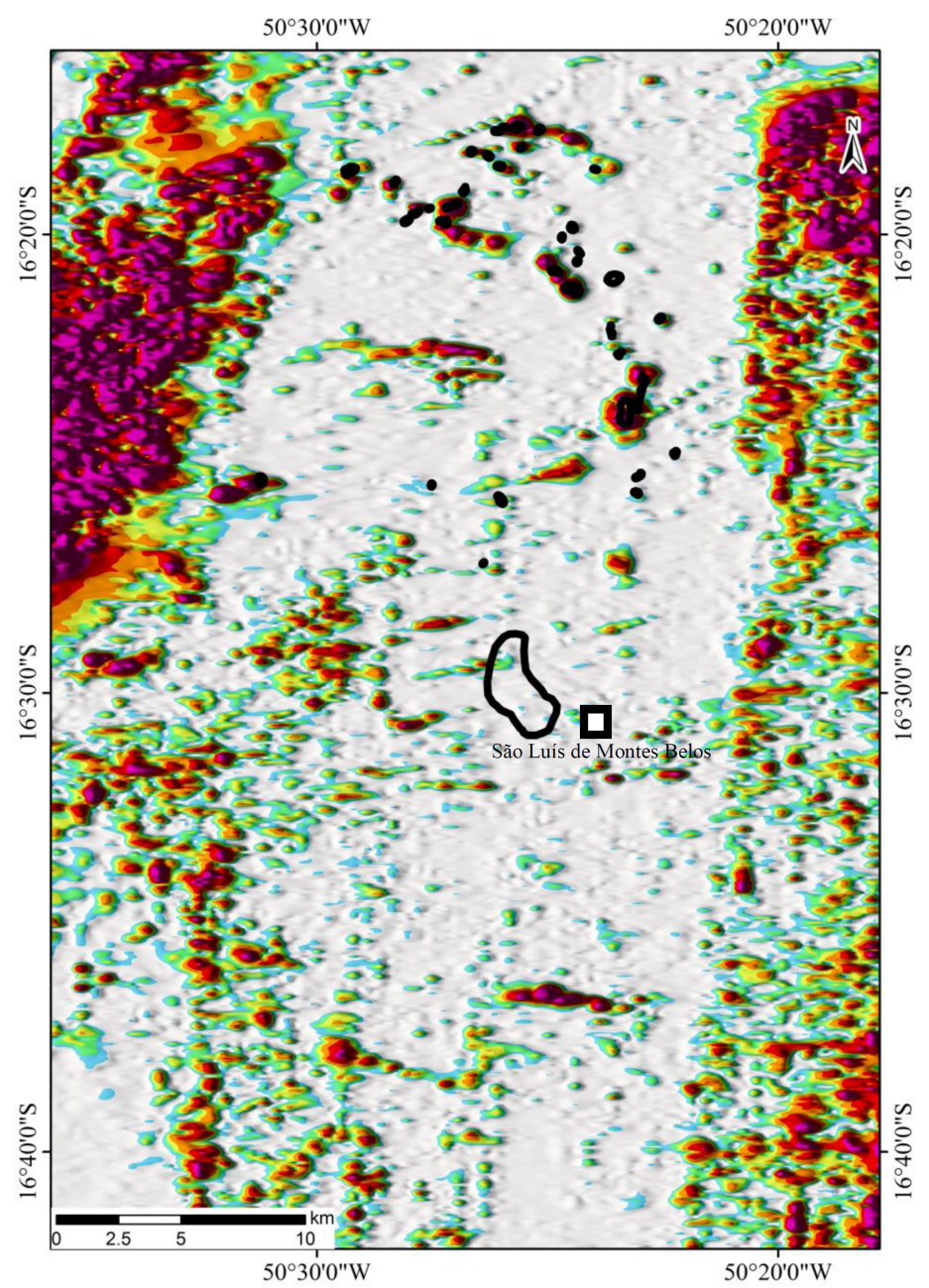

Figura IV - Imagem de Amplitude de Sinal Analítico, com picos de anomalia magnética realçados da região de ocorrência dos corpos ultramáficos da Suíte São Luís de Montes Belos. 
Tabela I - Sumário de idades das rochas do Arco Magmático Arenópolis e máfico-ultramáficas do Complexo Anápolis-Itauçu. 1 - Pimentel et al., 1991; 2 - Pimentel e Fuck, 1994; 3 - Pimentel et al., 1996; 4 - Gioia, 1997; 5 Nilson et al., 1997; 6 - Pimentel et al., 2003; 7 - Laux et al., 2004; 8 - Laux et al., 2005; 9 - Della Giustina et al., 2011; 10 - Guimarães et al., 2012; 11 - Motta de Araújo, 2012; 12 - Marques et al., 2016. UO = Unidade Ortognáissica, SMVS = Sequencia Metavulcanossedimentar, SA = Suíte Aragoiânia e SSN = Suíte granítica Serra Negra, MUM = Máfico-Ultramáfico.

\begin{tabular}{|c|c|c|c|c|c|c|c|c|}
\hline \multicolumn{9}{|c|}{ Arco Magmático Arenópolis } \\
\hline \multicolumn{9}{|c|}{$1^{\circ}$ Evento -900 e 800} \\
\hline & Unidade & Associação & $\begin{array}{l}\text { Idade (Ma) } \\
\text { - U-Pb } \\
\text { Zircão }\end{array}$ & $\begin{array}{l}\text { Idade (Ma) - } \\
\text { Sm-Nd }\end{array}$ & $\begin{array}{l}\text { Idade (Ga) - } \\
\text { TDM Sm-Nd }\end{array}$ & $\varepsilon_{\mathrm{Nd}}(\mathrm{T})$ & $\begin{array}{l}\text { Idade } \\
\text { (Ma) - } \\
\text { K-Ar }\end{array}$ & $\begin{array}{l}\text { Idade } \\
(\mathrm{Ma})- \\
\mathrm{Rb}-\mathrm{Sr}\end{array}$ \\
\hline \multirow{3}{*}{ UO } & Arenópolis & Granito-Gnaisse & $899 \pm 7^{1}$ & & & $+1,9 \mathrm{a}+3,2^{1}$ & & $818 \pm 57^{1}$ \\
\hline & Sanclerlândia & $\begin{array}{l}\text { Orthognaisse } \\
\text { Tonalítico }\end{array}$ & $822 \pm 7^{11}$ & 0,9 a $1.44^{4 \text { e } 11}$ & $+4 a+6^{11}$ & $+0,3^{7}$ & & $940^{2}$ \\
\hline & Iporá & Biotita Gnaisse & $804 \pm 6^{7}$ & & $1,18^{7}$ & $+0,3^{7}$ & & \\
\hline \multirow{3}{*}{ SMVS } & Arenópolis & Meta-riolito & $890 \pm 8^{1}$ & & 0,9 a $1,2^{1}$ & $+2,5 \mathrm{a}+2,8^{1}$ & & \\
\hline & $\begin{array}{l}\text { Córrego da Boa } \\
\text { Esperança }\end{array}$ & Xisto anfibolítico & $862 \pm 5^{7}$ & & 0,94 to $1,1^{7}$ & $+4,4 \mathrm{a}+5,5^{7}$ & & \\
\hline & Anicúns-Itaberaí & Metagabbro & $815 \pm 10^{7}$ & & 0,94 a $1,12^{7}$ & $+4,1 \mathrm{a}+4,4^{7}$ & & \\
\hline \multicolumn{9}{|c|}{$2^{\circ}$ Evento $780-750 \mathrm{Ma}$} \\
\hline \multirow{4}{*}{$\mathrm{UO}$} & Creoulos Granite & Muscovita Gnaisse & $784 \pm 14^{8}$ & & 1,07 a $1,47^{8}$ & $-1,8 a+3,6^{8}$ & & \\
\hline & I & Metatonalito & $770 \pm 8^{12}$ & & $0,86^{12}$ & $+5,41^{12}$ & & \\
\hline & Jaupacı Belt & Metatrondhjemito & $753 \pm 12^{12}$ & & $1,26^{12}$ & $+4,61^{12}$ & & \\
\hline & Lavrinha Granite & Granito milonítico & $748 \pm 4^{8}$ & & $0,89^{8}$ & $+4,8^{8}$ & & \\
\hline SMVS & Bom Jardim & Vulcânica ácida & $749 \pm 6^{10}$ & & 1,0 a $1,1^{10}$ & $+1,0 \mathrm{a}+4,6^{10}$ & & \\
\hline \multicolumn{9}{|c|}{$3^{\circ}$ Evento $670-625$} \\
\hline \multirow{6}{*}{ UO } & Matrinxã Gneiss & Metagranitóide & $669 \pm 3^{8}$ & & $0,99^{8}$ & $+2,2^{8}$ & & $895^{2}$ \\
\hline & Granito Choupana & Metagranodiorito & $662 \pm 12^{8}$ & & 1,06 a $1,09^{8}$ & $+1,7 \mathrm{a}+2,8^{8}$ & & \\
\hline & Palminópolis & Biotita gnaisse & $637 \pm 20^{8}$ & & 0,98 a $2,27^{8}$ & $-0,61^{8}$ & & \\
\hline & Turvânia & Biotita gnaisse & $630 \pm 5^{8}$ & & 0,99 a $1,11^{8}$ & $+0,3 \mathrm{a}+1,9^{8}$ & & \\
\hline & Iporá-Amorinópolis & Meta-riolito & $636 \pm 6^{1}$ & & 1,0 a $1,1^{1}$ & $+0,3$ a $5^{1}$ & & \\
\hline & Firminópolis & Hornblenda gnaisse & $634 \pm 8^{8}$ & & 1,1 a $1,4^{8}$ & $-1,7^{4}$ & & \\
\hline \multirow{3}{*}{ MUM } & $\begin{array}{c}\text { Americano do Brasil } \\
\text { Mangabal }\end{array}$ & Norito & $626 \pm 8^{7}$ & $612 \pm 66^{5}$ & & $+2,4 \mathrm{a}+3,1^{4 \mathrm{e} 5}$ & $\begin{array}{l}610 \pm 50^{4} \\
612 \pm 8^{4}\end{array}$ & $620 \pm 10^{5}$ \\
\hline & Córrego Seco & Diorito & $623 \pm 13^{7}$ & & $1,05^{7}$ & $+1,8 \mathrm{a}+1,11^{7}$ & & \\
\hline & Santa Bárbara & Anortosito & $598 \pm 8^{7}$ & & $1,25^{7}$ & $+2,2 \mathrm{a}+2,5^{7}$ & & \\
\hline \multicolumn{9}{|c|}{$4^{\circ}$ Evento $620-485$} \\
\hline SMVS & Jaupaci & Meta-riolito & $574 \pm 10^{12}$ & & $1,1^{12}$ & $+1,19^{12}$ & & \\
\hline \multirow{3}{*}{ AS } & Farturinha Granite & Biotita Granito & $614 \pm 5^{8}$ & & $1,0^{8}$ & $+4,5^{8}$ & & \\
\hline & Buriti de Goiás & Biotita Granito & $614 \pm 20^{11}$ & & 0,97 a $1,19^{11}$ & $+1,2$ to $+2,7^{11}$ & & \\
\hline & Mossamedes Granite & Biotita Granito & $548 \pm 11^{11}$ & & $0,93^{11}$ & $+2,57^{11}$ & & \\
\hline \multirow{6}{*}{ SSN } & $\begin{array}{c}\text { Rio Caiapó } \\
\text { Serra do Iran }\end{array}$ & $\begin{array}{l}\text { Granodiorito } \\
\text { Biotita Granito }\end{array}$ & & & & & & $\begin{array}{l}588 \pm 19^{3} \\
588 \pm 19^{3}\end{array}$ \\
\hline & Ivolândia Granite & Biotita Granito & $556 \pm 5^{11}$ & & $1,34^{11}$ & $-3,2^{11}$ & & \\
\hline & Messianópolis & Biotita Granito & $542 \pm 4^{11}$ & & $2,25^{11}$ & $-20^{11}$ & & \\
\hline & Pilolândia Granite & Granito Milonítico & $532 \pm 8^{11}$ & & 1,12 a $1,27^{11}$ & -1 a $-2,2^{11}$ & & \\
\hline & Iporá Granite & Biotita Granito & $511 \pm 6,9^{12}$ & & & & & $490 \pm 24^{1}$ \\
\hline & Serra Negra Granite & Biotita Granito & $506 \pm 3,6^{12}$ & & 1,23 a $1,5^{7}$ & $-3 a-4^{7}$ & & \\
\hline \multicolumn{9}{|c|}{ Anápolis Itauçu Complex } \\
\hline \multirow{4}{*}{ MUM } & Goianira-trindade & Leucogabro & $662 \pm 1^{9}$ & $621^{6}$ & 1,10 a $1,28^{9}$ & $-0,93 a+3,18^{9}$ & & \\
\hline & Damolândia & Leucogabro & $667 \pm 3^{9}$ & & 1,78 a $2,16^{9}$ & $-3,9$ a $-26,5^{9}$ & & \\
\hline & Taquaral & Amphibolito & $660 \pm 8^{9}$ & & 1,36 a $1,92^{9}$ & $-0,1$ a $-7,8^{9}$ & & \\
\hline & Águas Claras & Gabronorito & & $642^{5}$ & & & & \\
\hline
\end{tabular}




\section{2 - Vermiculita}

\section{1 - Características cristalográficas}

A vermiculita é um filossilicato 2:1, com dureza Mohs em torno de 1,5 e gravidade específica em torno de $2,3 \mathrm{~g} / \mathrm{cm}^{3}$ (Deer et al., 1992). Este filossilicato possui duas camadas estruturais constituídas por folhas tetraédricas de sílica (T) e uma folha central octaédrica $(\mathrm{O})$ de alumínio, com camadas interligadas por hidróxido de magnésio, ferro ou alumínio (Fig. V). A estrutura da vermiculita se difere das micas por conter camadas de moléculas de água com espessura de 4,98 Å (Klein e Dutrow, 2012).

A esfoliação é o único parâmetro que permite distinguir as características macroscópicas da vermiculita de micas como flogopita e biotita, enquanto que não há parâmetros para diferenciá-las por análise em microscopia. O fenômeno da esfoliação ocorre quando a vermiculita é aquecida a $300^{\circ} \mathrm{C}$ ou mais; assim, devido ao escape de vapor de água na estrutura da vermiculita, as ligações se quebram, ocorrendo dilatação perpendicular ao eixo "c" cristalográfico entre as lamelas (Deer et al., 1992).

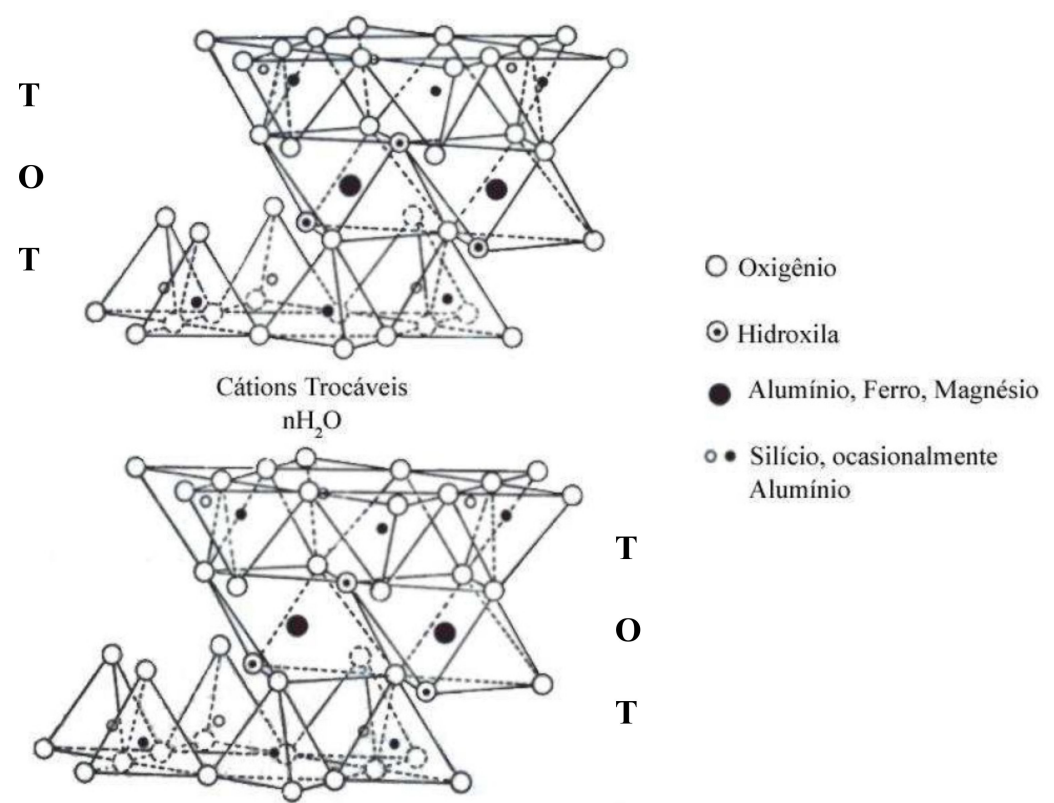

Figura V - Estrutura cristalina da vermiculita (modificado de Vieira Coelho 1986). T= tetraedro e O = octaedro.

Embora o magnésio seja o cátion interligante mais comum entre as camadas, este pode ser substituído por $\mathrm{K}, \mathrm{Ca}, \mathrm{Na}, \mathrm{Rb}, \mathrm{Cs}$, $\mathrm{Li}$ e $\mathrm{NH}_{4}$, enquanto que os elementos Ti, Li, Cr e Na podem ocorrer nos sítios octaédricos. Segundo De la Calle e Suquet (1988), os cátions $\mathrm{Na}^{+}, \mathrm{Ca}^{+2}, \mathrm{Mg}^{+2}$ e $\mathrm{K}^{+}$podem ser trocáveis entre si, o que não acontece com o conjunto dos cátions $\mathrm{K}, \mathrm{NH}_{4}, \mathrm{Rb}$ e $\mathrm{Cs}$. A fórmula química da 
vermiculita é portanto: $(\mathrm{Mg}, \mathrm{Ca})_{0,6-0,9}\left(\mathrm{Mg}, \mathrm{Fe}^{3+}, \mathrm{Al}\right)_{6.0}\left[(\mathrm{Si}, \mathrm{Al})_{8} \mathrm{O}_{20}\right](\mathrm{OH})_{4} \cdot \mathrm{nH}_{2} \mathrm{O}$ (Deer et al. 1992).

\section{2 - Ocorrências}

A vermiculita é um mineral secundário que só pode ser formado a partir de minerais com elevado teor de magnésio, cujos principais são flogopita e biotita, podendo também ser gerada a partir de anfibólios, piroxênios, olivinas e cloritas (Bush, 1976; De la Calle e Suquet, 1988). Os processos de formação de vermiculita podem ser por intemperismo, hidrotermalismo ou variação do nível do lençol freático (Basset, 1963).

Em depósitos com ocorrência de vermiculita e micas magnesianas, é comum a presença de interestratificados de lamelas de vermiculita com lamelas de flogopita ou biotita. Este empilhamento foi classificado por Gruner (1934) como hidroflogopita ou hidrobiotita, uma fase intermediária da alteração da mica para a vermiculita. Segundo Hindman (1992), são necessárias três etapas para este processo de alteração. O autor ilustra a transformação de uma biotita para vermiculita em uma solução férrica, nas equações 1,2 e 3.

Na primeira etapa, o $\mathrm{Fe}^{2+}$ no sítio octaédrico é oxidado:

$$
\mathrm{K}_{2}\left(\mathrm{Mg}_{4}, \mathrm{Fe}^{2+}{ }_{2}\right)\left[\mathrm{Si}_{6} \mathrm{Al}_{2} \mathrm{O}_{20}\right](\mathrm{OH})_{4}+\mathrm{Fe}^{3+} \rightarrow \mathrm{K}_{2}\left(\mathrm{Mg}_{4} \mathrm{Fe}^{+2} \mathrm{Fe}^{3+}\right)\left[\mathrm{Si}_{6} \mathrm{Al}_{2} \mathrm{O}_{20}\right](\mathrm{OH})_{4}+\mathrm{Fe}^{+2} \text { (Equação 1) }
$$

A segunda etapa começa quando as camadas T-O-T (Fig. V) estão suficientemente distantes para permitir uma troca de íons, acarretando na lixiviação do potássio em excesso da camada interligante, de acordo com a equação 2 :

$$
\mathrm{K}_{2}\left(\mathrm{Mg}_{4} \mathrm{Fe}^{2+} \mathrm{Fe}^{3+}\right)\left[\mathrm{Si}_{6} \mathrm{Al}_{2} \mathrm{O}_{20}\right](\mathrm{OH})_{4} \rightarrow \mathrm{K}\left(\mathrm{Mg}_{4}, \mathrm{Fe}^{2+} \mathrm{Fe}^{3+}\right)\left[\mathrm{Si}_{6} \mathrm{Al}_{2} \mathrm{O}_{20}\right](\mathrm{OH})_{4}+\mathrm{K}^{+} \text {(Equação 2) }
$$

Por fim, toda a concentração do $\mathrm{K}$ da camada interligante é exaurida e o íon ferroso é oxidado, conforme a equação 3:

$$
\begin{gathered}
\mathrm{K}\left(\mathrm{Mg}_{4} \mathrm{Fe}^{2+} \mathrm{Fe}^{3+}\right)\left[\mathrm{Si}_{6} \mathrm{Al}_{2} \mathrm{O}_{20}\right](\mathrm{OH})_{4}+0.5 \mathrm{Mg}^{2+}+\mathrm{nH}_{2} \mathrm{O} \rightarrow\left(\mathrm{Mg}_{0.5} \mathrm{nH}_{2} \mathrm{O}\right)\left(\mathrm{Mg}_{4} \mathrm{Fe}^{3+}\right)\left[\mathrm{Si}_{6} \mathrm{Al}_{2} \mathrm{O}_{20}\right](\mathrm{OH})_{4}+\mathrm{K}^{+}+\mathrm{Fe}^{2+} \\
\text { (Equação 3) }
\end{gathered}
$$

A estrutura química do interestratificado é difícil de ser simplificada, pois esta varia do produto da equação número 1 ao reagente da equação número 3 .

As rochas que hospedam a vermiculita são comumente ultramáficas intrusivas, tais como piroxenitos, biotititos, flogopita-serpentinitos. Porém, tal argilomineral também ocorre associado a granitos alcalinos e sienitos (Hindman, 1994; Dill, 2010). 
Segundo De la Calle e Suquet (1988), as evidências de vermiculita com gênese hidrotermal seriam sua associação com minerais de alta temperatura e a presença deste mineral em grandes profundidades (maiores do que 61 metros). As evidências da formação por intemperismo seriam (i) o fato da biotita e flogopita alterarem facilmente para vermiculita em temperatura ambiente; (ii) o potássio ser um cátion trocável em baixas temperaturas; (iii) o aumento da quantidade de lamelas de mica em relação às lamelas de vermiculita à medida que a profundidade aumenta (iv) a presença de biotita inalterada no interior do piroxenito e (v) ocorrência de interestratificado de vermiculita/mica.

\section{3 - Aplicações}

As propriedades da vermiculita permitem que este mineral tenha uma infinidade de aplicações nos mais diversos setores.

A vermiculita esfoliada (expandida) possui densidade até dez vezes menor que a vermiculita não expandida (Ugarte et al., 2005), sendo este o principal aspecto para sua aplicação industrial. Além da capacidade de expansão, a vermiculita possui uma baixa condutividade térmica, um excelente isolamento acústico, é hidrofóbica, incombustível, ou seja, não possui componentes orgânicos, possui uma elevada capacidade de retenção de água e elevada capacidade de troca catiônica (Sznelwar e Scalabrin, 2009).

A baixa densidade e baixa condutividade térmica, assim como sua eficácia em isolamento de sons, tornam a vermiculita um mineral largamente utilizado na construção civil para a fabricação de concretos leves, argamassas acústicas e térmicas de revestimento e câmaras de revestimento ao frio. Por possuir baixa condutividade térmica, é também muito utilizada na indústria siderúrgica, metalúrgica e automotiva.

A presença de íons trocáveis localizados entre camadas de moléculas de $\mathrm{H}_{2} \mathrm{O}$ e a capacidade da estrutura de reter quantidades variáveis de $\mathrm{H}_{2} \mathrm{O}$ são de grande importância para a agricultura. Quando a estrutura da vermiculita é saturada com $\mathrm{H}_{2} \mathrm{O}$, o espaçamento basal é de aproximadamente 14,8 A. Essa água pode ser gradualmente extraída ao longo do eixo c, levando a um espaçamento basal de $9 \AA$ para a vermiculita sem água interlamelar (Klein e Dutrow, 2012). A vermiculita na forma expandida constitui-se também em um ótimo condicionador de solos ácidos e argilosos, por auxiliar na correção do pH (Ugarte et al., 2005).

A vermiculita, por ser hidrofóbica, pode ser utilizada para coleta de hidrocarbonetos em meio aquoso. Quando modificada por tratamento químico, pode ser 
utilizada com êxito na remoção de resíduos nucleares e tratamento de esgotos tóxicos (Ugarte et al., 2005; Sznelwar e Scalabrin, 2009).

\section{4 - Depósitos de vermiculita}

Os maiores depósitos de vermiculita estão localizados na região de Palabora, nordeste de Transvaal na África do Sul e em Libby, Montana, EUA, e ocorrem associados a complexos ultramáficos intrusivos (Dill, 2010). Os depósitos com ocorrência de processos hidrotermais e de intemperismo mais estudados são os depósitos de Libby (Basset, 1959), Hafafit no Egito (Amin e Afia, 1954; Harraz e Hamdy, 2010), e no Maciço da Bohemia, Áustria (Götzinger, 1987). Todos esses são corpos ultramáficos cortados por intrusões pegmatíticas félsicas, provável percursor dos eventos hidrotermais em cada complexo.

Os depósitos de vermiculita no Brasil são associados a complexos carbonatíticos e ultramáficos, com poucos economicamente viáveis. A extração de vermiculita em complexos carbonatíticos ocorre apenas no depósito de Catalão, Goiás, enquanto que os depósitos em rochas nos demais tipos de rochas ultrabásicas ocorrem em São Luís de Montes Belos no estado Goiás, Queimada Nova no Piauí, Santa Luzia na Paraíba e em Brumado na Bahia. 


\section{Referências}

Amaro, V.E., 1989. Geologia e petrologia da sequencia metavulcânica de Jaupaci GO e lineamentos associados. Tese de Mestrado. Universida de Brasília, $230 \mathrm{p}$.

Amin M. S., Afia M. S., 1954. Anthophyllite-Vermiculite Deposit of Hafafit, Eastern Desert, Egypt. Economic Geology. 49, 317-327.

Baêta, Jr. J.D., Moreton, L.C., 1999. Geologia. Programa Levantamentos Geológicos Básicos do Brasil. Sanclerlândia, Folha SE.22-X-A-II, Morro Agudo de Goiás, Folha SD.22-Z-C-II, Goiás, Folha SD.22Z-C-V, Esca la 1:100.000. Estado de Goiás. 5, 11 - 59.

Baldwin, J.A., Powell, R., Brown, M., Moraes, R., Fuck, R.A., 2005. Modelling of mineral equilibra in ultrahigh-temperature metamorphic rocks from the Anápolis-Itauçu Complex, central Brazil. Journal of Metamorphic Geology. 23, 511-531.

Bassett, W. A., 1959. Origin of the vermiculite deposit at Libby, Montana. The American Mineralogis. 44, 282-299.

Basset, W.A., 1963. The geology of vermiculite occurrences. Clays and Clay Minerals 10, 61-69.

Bush, A.L., 1976. Vermiculite in the United States. Montana Bureau of Mines and Geology. In: 11th Industrial Minerals Forum, Montana Bureau of Mines and Geology, Special Publication. 74, 146-155.

Candia Fornoni M.A., 1983. Petrologia dos complexos mafico-ultramaficos de Mangabal I e Mangabal II, Sanclerlândia, Goiás. Tese de Doutorado, Instituto de Geociências Universidade de São Paulo, 400 p.

Danni, J.C.M., Dardenne, M.A., Fuck, R.A., Ribeiro, M.J., 1973. Geologia da extremidade sudoeste de serra Dourada (Goias, Brasil). Revista Brasileira de Geociências. 3, 160-180.

De la Calle, C. e Suquet, H., 1988. Vermiculite. In: Hydrous Phyllosilicates. Reviews in Mineralogy. Mineralogical Society of America. 19, 455-496.

Deer W.A.; Howie R.A.; Zussman J. 1992. Vermiculite. In: An Introduction to the Rock Forming Minerals.2nd end Longman, Harlow, Essex. 377-381.

Della Giustina, M.E.S.; Pimentel,M.M.; Ferreira filho, C.F.; De Hollanda, M.H.B.M., 2011. Dating coeval mafic magmatism and ultrahight temperature metamorphism in the Anápolis-Itauçu complex, Central Brazil. Lithos. 134, 82-102.

Dill H.G. 2010. Clay Minerals. In The chessboard\| classification scheme of mineral deposits: Mineralogy and geology from aluminum to zirconium. Earth-Science Reviews. 51, 351-368.

Gioia S.M.C.L., 1997. Preparação da Metodologia Sm-Nd para Datação de Amostras Geológicas e sua Aplicação em Rochas das Áreas de Firminópolis, Fazenda Nova e Americano do Brasil—GO. Tese de Mestrado, Universidade de Brasília, 100p.

Götzinger M. A., 1987. Mineralogy and Genesis of Vermiculite in Serpentinites of the Bohemian Massif in Austria. Springer Wien. Heidelberg - Germany. Mineralogy and Petrology. 36, 2, 93-110.

Guimarães, S,B. Moura, M, A. Dantas, E . L., 2012. Petrology and geochronology of Bom Jardim copper deposit. Brazilian Journal of Geology. 42, 4, 841-862.

Gnuner, J W., 1934. The structures of vermiculites and their collapse by dehydration: American Mineralogist. 19, 557-575.

Harraz H.Z. e Hamdy M.M., 2010. Interstratified vermiculite-mica in the gneiss-metapelite-serpentinite rocks at Hafafit area, Southern Eastern Desert, Egypt: From metasomatism to weathering. Journal of African Earth Sciences. 305-320.

Hindman J. R., 1992. Vermiculite. In: Industrial Minerals and Rocks. Society for Mining, Metallurgy, and Exploration. London - UK. 5 ${ }^{\text {a }}$ Ed. 1103-1111.

Hindman, J.R., 1994. Vermiculite. In: Carr, D.D. (Ed.), Industrial Minerals and Rocks, 6th ed. Society for Mining,Metallurgy, and Exploration, Inc, Littleton, Colorado. 1103-1111.

Junges S.L., Pimentel M.M., Moraes R., 2002. Nd isotopic study of the Neoproterozoic Mara Rosa Arc, central Brazil: implications for the evolution of the Brasília Belt. Precambrian Research. 117, 101118.

Klein C. e Dutrow B., 2012. Química dos Cristais de Silicatos Formadores de Rocha. In Manual de ciências dos Minerais, $23^{\circ} \mathrm{ed}$. Trad. Rualdo Menegat. Porto Alegre, Bookman. 18, 463-511.

Lacerda Filho J. V. de, Rezende A., Silva, A. de, 1999. Programa Levantamentos Geológicos do Brasil. Geologia e Recursos Minerais do Estado de Goiás e Distrito Federal. 3, $27-29$.

Laux J.H., Pimentel M.M., Dantas E.L., Armstrong R., Armele A., Nilson A.A., 2004. Mafic magmatism associated with the Goiás Magmatic Arc in the Anicuns region, Goiás central Brazil: Sm-Nd isotopes and new ID-TIMS and SHIRIMP U-Pb data. Journal of South American Earth Sciences. 16, 7, 599614.

Laux, J.H., Pimentel, M.M., Dantas, E.L. Armstrong, R., Junges, S.L., 2005. Two Neoproterozoic crustal events in the Brasília Belt, central Brazil. Journal of South American Earth Sciences.183-198.

Marques, G. C., Oliveira, C. G., Pimentel M.M., 2016. The Jaupaci Belt (770-500 Ma), Goiás Magmatic Arc: $\mathrm{U}-\mathrm{Pb}$ and $\mathrm{Sm}-\mathrm{Nd}$ isotopic data and implications for the tectonic evolution of a Neoproterozoic Arc in Central Brazil. Submmited. 
Metago, 1978. Complexo máfico ultramáfico de Americano do Brasil. Relatório de pesquisa DNPM, Não publicado.

Moraes, R., Brown, M., Fuck, R.A., Camargo, M.A., Lima, T.M., 2002. Characterization and P-T evolution of melt-bearing ultrahigh-temperature granulites: an example from the Anápolis-Itauçu Complex of the Brasília Fold Belt, Brazil. Journal of Petrology. 43, 9, 1673-1705.

Moraes, R., Fuck, R.A., Brown, M., Piccoli, P., Baldwin, J., Dantas, E.L., Laux, J.H., Junges, S., 2007. Wollastonite-scapolite-clinopyroxenemarble of the Anápolis-Itauçu Complex, Goiás: more evidence of ultrahigh-temperature metamorphism. Revista Brasileira de Geociencias. 37, 4, 11-17.

Mota e Silva, J.; Ferreira Filho, C.F.; Bühn, B. e Dantas E.L., 2011 Geology, petrology and geochemistry of the -Americano do Brasill layered intrusion, central Brazil, and its $\mathrm{Ni}-\mathrm{Cu}$ sulfide deposits. Mineralium Deposita. 46, 57-90.

Motta-Araújo, J.G., 2012. Eventos Ígneos e metamórficos neoproterozoicos/eo-paleozoicos no arco magmático de Arenópolis, Goiás. Tese de doutorado, Universidade de Brasília, 73 p.

Nilson, A.A, Gioia,S., Pimentel,M.M., 1997, Idade Sm-Nd do Complexo Máfico-Ultramáfico de Americano do Brasil, Goiás e características isotópicas das rochas encaixantes. In: Congresso Brasileiro de Geoquímica., 6., Anais V.2. SBGq, Salvador. 643-645.

Nilson AA, Santos MM, Cuba EA, Sá CMG 1986. Jazida de níquel, cobre e cobalto de Americano do Brasil, Goiás. In: Schobbenhaus C, Coelho CES (eds) Principais Depósitos Minerais do Brasil II. 257-273.

Nunes, N.S.V., 1990. Geologia e Potencial Mineral da Região de Anicuns, Goiás. Tese de Mestrado, Universidade de Brasália, 188p.

Pimentel, M.M. e Fuck, R.A., 1986. Geologia da sequencia vulcanosedimentar de Aren6polis (GO). Revista Brasileira de Geociências. 16, 217-223.

Pimentel, M.M. e Fuck, R.A. 1992. Neoproterozoic crustal accretion in central Brazil. Geology. 20, 375379.

Pimentel, M.M. e Fuck, R.A. 1994. Geocronologia Rb-Sr da porção sudeste do maciço de Goiás. Revista Brasileira de Geociências. 24 (2), 104-111.

Pimentel,M.M., Fuck,R.A. e Alvarenga,C.J.S. 1996. Post-Brasiliano (Pan-African) high-K granitic magmatism in central Brazil: late precambrian/early Paleozoic extension. Precambrian Research. 80, 217-238.

Pimentel, M.M., Fuck, R.A., Ferreira Filho, C.F., Araújo, S.M., 2000. The basement of the Brasília Belt and the Goiás Magmatic Arc. In: Cordani, U.G., Milani, E.J., Thomaz Filho, A., Campos, D.A. (eds) Tectonic Evolution of South America. 31st International Geological Congress, Rio de Janeiro. 195229.

Pimentel M.M., Heaman L., Fuck R.A. 1991. U-Pb zircon and sphenc geochronology of late Protcrozoic volcanic arc rock units from southwestern Goiás, Central Brazil. Journal of South American Earth Sciences. 4, 329-339.

Pimentel M. M., Jost H. e Fuck R. A. 2004. O Embasamento da Faixa Brasília e o Arco magmático de Goiás. Geologia do Continente Sul-Americano: evolução da obra de Fernando Flávio Marques de Almeida. Ed. Beca, São Paulo. 31, 355-368.

Seer, H.J., 1985. Geologia, Deformação e Mineralização de Cobre no Complexo Vulcanossedimentar de Bom Jardim de Goiás. Tese de Mestrado, Universidade de Brasília, 181 p.

Silva, F.O., 1991. Geologia, estrutura, petrologia e mineralização de Fe, Ti e V associadas ao complexo gabro-anortosítico acamadado de Santa Bárbara (Goiás). Tese de Mestrado, Universidade de Brasília, $190 \mathrm{p}$.

Silva, H. H. A. B., 2006. Caracterização mineralógica e filiação da vermiculita da mina Cerrado III SAnclerlândia-GO. Tese de Mestrado, Instituto de Geociências, Universidade de Brasília. 126 p.

Sznelwar,J. J. e Scalabrin, R., 2009. Perfil da Vermiculita, Relatório Técnico 48 In: Projeto Estal Projeto de Assistência Técnica ao Setor de Energia. 35.

Teixeira A. S., Silva H. H. A. B., Guimarães E. M., Lenharo S. L. R. 2006. Rochas ultramáficas Mineralizadas a Vermiculita da Região de Sanclerlândia/SãoLuís de Montes Belos, Estado de Goiás. XLIII Congresso Brasileiro de Geologia.

Vieira - Coelho, A. C., 1986. Estudo, em escala de laboratório, do inchamento em água de vermiculita brasileiras tratadas com soluções salinas inorgânicas. Tese de Mestrado, Universidade de São Paulo.

Ugarte, J.F.O., Sampaio J.A. e França S.C.A., 2005 Vermiculita, In:CETEM: Rochas e minerais industriais.32, 677-698. 
To be sumited to Ore Geology Reviews

Mineralogy and Petrology of vermiculites hydrothermal deposit of São Luís de Montes Belos, Goiás Magmatic Arc.

Hammel Assunção Oliver Macedo ${ }^{1}$ Maria Emilia Schutesky Della Giustina ${ }^{1}$ Claudinei Gouveia de Oliveira ${ }^{1}$ Igor Fernandes Praxedes ${ }^{2}$

${ }^{1}$ Instituto de Geociências, Universidade de Brasília, Brasília-DF, 70910-900, Brazil

${ }^{2}$ Brasil Minérios S.A.. 


\section{Resumo}

Vermiculita ocorre apenas nos corpos da Suíte São Luís de Montes Belos, dentre as suítes máfico - ultramáficas pertencentes ao Arco Magmático Arenópolis, localizada na porção central do Brasil. Os corpos dessa suíte são acamadados, intensamente hidrotermalizados, constituídos por peridotitos e clinopiroxenitos e seus derivados hidrotermais denominados srp-mt-vrm - flogopitito e vrm flogopitito, respectivamente, intrudidos por hornblenditos, diques e veios quartzo - feldspáticos. A paragênese mineral hidrotermal é constituída principalmente por flogopita, tremolita - actinolita e titanita, com os processos hidrotermais e metassomáticos que afetaram a Suíte São Luís de Montes Belos, relacionado à intrusão dos diques félsicos. A vermiculita ocorre tanto disseminada nas rochas hidrotermalizadas, quanto na zona de contato entre os diques félsicos e a rocha encaixante. Nas rochas da Suíte São Luís de Montes Belos ocorrem dois tipos de vermiculita com aspectos macroscópicos distintos: (i) associada à srp-mt-vrm - flogopitito; (ii) associada a vrm - flogopitito. Estudos de química mineral, litogeoquímica, análises isotópicas e análises geocronológicas das rochas de diferentes corpos da suíte foram realizados para entender a origem da vermiculita e dos processos magmáticos e hidrotermais das rochas. Os tipos de vermiculita possuem química mineral relativamente distinta, porém ambos os tipos foram geradas a partir da alteração da flogopita, evidenciado pela presença de hidroflogopita em ambas as rochas hidrotermalizadas. A formação da flogopita ocorreu principalmente durante o intemperismo, porém o processo de vermiculitzação iniciou por metassomatismo no final do evento hidrotermal. Datação pelo método U-Pb em titanita acusou idades de 556 Ma para o início do processo de formação da vermiculita a partir da flogopita, idade semelhante a diversas intrusões de granitoides potássicos no Arco Magmático Arenópolis. Apesar das rochas da Suíte São Luís de Montes Belos estarem intensamente afetadas por processos hidrotermais, ocorre porções preservadas com mineralogia ígnea e sequencia de cristalização definifa por $\mathrm{Ol}>\mathrm{Ol}+\mathrm{Cpx}>\mathrm{Ol}+\mathrm{Cpx}+\mathrm{Phl}>\mathrm{Cpx}+\mathrm{Phl}$. Valores composicionais da olivina $\left(\mathrm{Fo}_{87}\right)$ sugerem magma parental primitivo. As rochas da Suíte São Luís de Montes Belos são derivadas de um magmatismo contendo potássio, gerado a partir do manto metassomatizado, evidenciado pela presença de flogopita magmática, enriquecimento de elementos terras raras leves em relação aos pesados e $\varepsilon N d(T)$ negativo $(-3,2$ a $-5,2)$. Os corpos ultramáficos possuem formato elipsoidal com eixo maior paralelo a zona de cisalhamento São Luís de Montes Belos. As características permitiram concluir que as rochas da Suíte São Luís de Montes Belos são pós-colisionais ao fechamento Faixa Brasília e sincinemática a zona de cisalhamento transcorrente São Luís de Montes Belos, com magmatismo gerado no manto litosférico subcontinental metassomatizado em um ambiente envolvendo subducção, hidratação e metassomatismo da cunha mantélica. Os fluidos hidrotermais podem ter sido gerados por fusão da crosta continental inferior, desenvolvida a partir da interação do material do manto astenosférico e o manto litosférico.

Palavras Chave: Suíte São Luís de Monstes Belos, vermiculita, hidrotermal, flogopita, metassomatizado, pós-colisional. 


\section{Introdução}

A vermiculita é um argilomineral com propriedades físicas e químicas semelhantes a micas trioctraédricas, particularmente flogopita e biotita. Este mineral difere das micas por não conter $\mathrm{K}^{+}$e $\mathrm{Fe}^{2+}$, porém possui grande quantidade de $\mathrm{Fe}^{3+}$ e água. A vermiculita ocorre somente como produto de alteração de outros minerais, por processos de intemperismo, hidrotermalismo ou devido à percolação de água do lençol freático (De la Calle e Suquet 1988). Este argilomineral é formado, principalmente, a partir de flogopita ou biotita, e menos comumente, por alteração de piroxênios, anfibólios, olivinas, cloritas ou outros argilominerais magnesianos. Nos depósitos onde a vermiculita é originada a partir da mica, ocorrem lamelas com concentrações intermediárias de $\mathrm{K}^{+}$e $\mathrm{H}_{2} \mathrm{O}$ entre os dois minerais e também interestratificados entre o argilomineral e a mica, classificado por Gruner (1934) como hidromica.

Os maiores depósitos de vermiculita estão associados a complexos ultramáficos acamadados ou carbonatitos intrudidos por sienito (Basset, 1963; Borovikov,1962). Dentre os complexos ultramáficos intrudidos por sienitos, os mais estudados são Libby (EUA), Hafafit (Egito) e os corpos do Maciço da Bohemia (Áustria). O depósito de Libby, maior depósito de vermiculita do mundo quando operava, foi influenciado por processos hidrotermais responsáveis pela geração de biotita em clinopiroxenitos, porém com vermiculita formada a partir da mica durante intemperismo (Basset, 1959). Em Hafafit, a vermiculita ocorre associada a zonas de contato entre diques pegmatíticos félsicos e serpentinitos ou metapelitos. A formação do argilomineral foi primeiramente atribuída a processos hidrotermais (Amin e Afia, 1954). Entretanto, Harraz e Handy (2010) constataram a presença de flogopita, biotita e interestratificado de vermiculita/mica e conferiu que as micas são produto de processos hidrotermais, porém a vermiculita foi gerada principalmente durante intemperismo, com processo de vermiculitização iniciada durante o hidrotermalismo. No maciço da Bohemia ocorrem corpos ultramáficos serpentinizados, intrudidos por diques félsicos, com vermiculita e dispostos ao longo de um trend NNE - SSW. A vermiculita ocorre associada às intrusões félsicas e preenchendo fraturas, ambos os tipos originados por processos hidrotermais (Gotzinger, 1987). Além do hidrotermalismo nesses corpos estar relacionado às intrusões félsicas, todos os depósitos ocorrem próximos a zonas de cisalhamento. 
A Suíte São Luís de Montes Belos (SSLMB) pertence ao conjunto de intrusões máfico - ultramáficas encaixadas em unidades ortognáissica, localizados na porção centro-sul do Brasil. Dentre essas unidades, os corpos pertencentes à SSLMB são os únicos com vermiculita associada. Esses corpos são ultramáficos e intrudidos por diques félsicos, características semelhantes aos depósitos de Libby, Hafafit e os corpos do maciço da Bohemia. Em estudos anteriores realizados por Silva (2006), foram identificados dois tipos de vermiculita distintas. Um tipo associada à peridotitos, originada de anfibólios por processos hidrotermais e outro tipo associada à piroxenito, originada a partir de biotita durante o intemperismo. Nesse artigo, nós apresentamos dados inéditos sobre os tipos de vermiculita que ocorrem na SSLMB e os primeiros dados quanto à geoquímica de rocha total e geocronologia que apontaram características únicas a SSLMB e darão margem a uma série de novos estudos.

\section{Exploração}

\subsection{Histórico}

Os corpos da SSLMB foram descobertos durante um mapeamento geológico regional desenvolvido pela Minebra (1974 apud Olivatti e Reis da Silva, 2008), com a primeira indústria de beneficiamento e industrialização de vermiculita implantada no ano de 1977. Em 2002, a empresa Brasil Minérios S.A. comprou a reserva mineral, estimada de 286 mil toneladas do minério de vermiculita, e investiu em prospecção regional, encontrando novos corpos e aumentando a reserva para mais de 2,7 milhões de toneladas, com teores médios de vermiculita variando entre $25 \%$ e $35 \%$. Com a aquisição de áreas com vermiculita na região de Catalão, Goiás, a empresa se tornou a maior produtora de concentrados de vermiculita e vermiculita expandida do Brasil e terceira maior do mundo com reserva estimada total em 2012 com cerca de 19,8 milhões de toneladas, destes 4,3 milhões na região de São Luís de Montes Belos (região deste trabalho). Em 2014, foram encontrados novos alvos juntamente com os autores desse artigo e em 2015 a produção anual fechou em torno de 50 mil toneladas na região de São Luís de Montes Belos.

\subsection{Beneficiamento}

Os corpos da SSLMB são constituídos por peridotitos e piroxenitos afetados por processos hidrotermais e de intemperismo que formaram tipos de vermiculita distintos. 
Esses processos que levaram à mineralização da SSLMB, discutidos no decorrer desse artigo, também influenciaram na formação de serpentina, clinoanfibólios e ortoanfibólios prismáticos, minerais indesejáveis para o mercado industrial. Portanto, são designados profissionais especializados para acompanhar a etapa de escavação, removendo todo o material indesejável e áreas influenciadas por esses produtos. Devido à ocorrência de dois litotipos distintos, há uma variação do volume de minério entre os dois, assim a Brasil Minérios S.A. adotou um complexo e eficiente sistema de blendagem para a obtenção do melhor tipo de produto para ser comercializado.

A empresa adota um processo de beneficiamento rigoroso e após as etapas de escavação e blendagem, todo o material é analisado em laboratório da própria Brasil Minérios S.A. e pelos laboratórios Institute of Occupational Medicine (IOM) e do RJ Lee Group (RJLG) de modo que todo material comercializado é isento desses minerais indesejáveis. Na própria empresa são realizados os testes para caracterização dos produtos, exigidos pela The Vermiculite Association (TVA), que envolvem o controle do conteúdo de impurezas e determinação de massa específica aparente, granulometria e rendimento. Para mais detalhes do modo de produção da Brasil Minérios S.A., consulte o site http://www.brasilminerios.com.br/.

\section{Geologia Regional}

\subsection{Faixa Brasília}

A Província Tocantins é produto de um orógeno neoproterozoico desenvolvido durante a orogênese Brasiliano/Pan-Anfricano (Almeida et al., 1977; 1981), pela colisão entre os Crátons Amazônico, a noroeste, São Francisco-Congo, a leste, e Paranapanema, atualmente recoberto pela Bacia do Paraná, a sudoeste (Delgado et al., 2003). Esta província é compartimentada nas faixas dobradas Araguaia, Paraguai e Brasília (Fig. 1).

A área de estudo é inserida na Faixa Brasília (Fig. 1), a qual apresenta um arcabouço tectônico complexo com dois domínios distintos, norte e sul, com estilo deformacional predominante para NE-SW e NW-SE, respectivamente, separados pela sintaxe dos Pirineus (Araújo Filho, 2000; Fuck et al., 2005).

Valeriano (2008) sugeriu a compartimentação da Faixa Brasília em cinco domínios distintos, de leste para oeste da Faixa: (i) zona de antepaís do paleocontinente 
São Francisco, com embasamento de granito-greenstone arqueano-paleoproterozoico sobreposto por rochas metassedimentares neoproterozoicas de baixo grau metamórfico do Grupo Bambuí; (ii) zona Alóctone Externa, representada por rochas metassedimentares de rifte e de margem passiva depositadas sobre um bloco crustal paleoproterozoico (Cavalcante-Natividade); (iii) zona Alóctone Interna, associada ao núcleo metamórfico da Faixa Brasília, constituído por rochas metamórficas de alto grau do complexo Anápolis-Itauçú, expostas em meio a rochas dos grupos Araxá e Canastra pertencentes a um sistema de nappes, metamorfisadas em fácies xisto verde alto a granulito, empurradas sobre o cinturão de dobras e empurrões da zona externa (Baldwin et al., 2005; Della Giustina et. al., 2011b; Moraes et al., 2002, 2007; Piuzana et al., 2003); (iv) Maciço do Goiás, um núcleo arqueano-paleoproterozoico interpretado como microcontinente ou terreno alóctone siálico, acrecionado ao Cráton São Francisco durante a Orogênese Brasiliana; a leste núcleo são associados terrenos TTG arqueanos, sequências greenstone-belts arqueanas-paleoproterozoicas e os complexos máficoultramáficos de Niquelândia, Barro Alto e Cana Brava de idade meso-neoproterozoica (Almeida et al., 1981; Della Giustina, et. al., 2009; 2011a; Ferreira Filho, 1998; Fuck et al., 1993; 1994; Pimentel et al., 2000); e o (v) Arco Magmático de Goiás (AMG) de idade neoproterozoica, o qual será descrito em detalhe a seguir.

\subsection{Arco Magmático de Goiás (AMG).}

O AMG está localizado na porção oeste da Faixa Brasília e limita-se com o Maciço do Goiás pelos lineamentos Rio dos Bois, Moiporá-Novo Brasil e Mossâmedes (Fig. 1). O Arco representa uma zona de acresção de crosta continental juvenil de idade neoproterozoica, cristalizados em dois episódios principais; o primeiro entre 920-800 Ma (Matteini et al., 2010; Pimentel et al., 2004) e o segundo entre 670-620 Ma (Laux et al., 2004 e 2005 e Pimentel et al., 2004). Em ambos os intervalos foram formados rochas metavulcânicas e metassedimentares gerados em ambientes de arco de ilha e arco continental, respectivamente, separados por ortognaisses de composição granítica a diorítica (Fuck et al., 2005; Laux et al., 2004; Pimentel et al., 2004 e Matteini et al., 2010).

Duas faixas com direções NNE a norte (Arco Magmático Mara Rosa) e NNW a sul (Arco Magmático Arenópolis) compõem o AMG. O Arco Magmático Mara Rosa compreende sequências metavulcanossedimentares, onde dominam rochas detríticas 
metassedimentares, com relação à metavulcânicas e metassedimentares químicas. Enquanto no Arco Magmático Arenópolis (AMA), área do estudo, predominam rochas metavulcânicas de composição félsica a intermediária (Junges et al., 2002; Laux et al., 2005; Oliveira et al., 2015; Pimentel et al., 1997; Viana et al., 1995).

$\mathrm{O}$ metamorfismo atou em dois momentos distintos, o mais antigo entre $760 \mathrm{e}$ 730 Ma (Junges et al., 2002) e o mais novo entre 610 e 604 Ma (Pimentel et al., 2001). O primeiro evento, em fácies metamórfica anfibolito, está relacionado à acresção de arcos de ilhas, e o evento mais novo, em fácies xisto verde, é associado à colisão final e fechamento da bacia entre os crátons Amazônico e São Francisco no final da orogênese Brasiliana nesta porção do Gondwana (Junges et al., 2002).

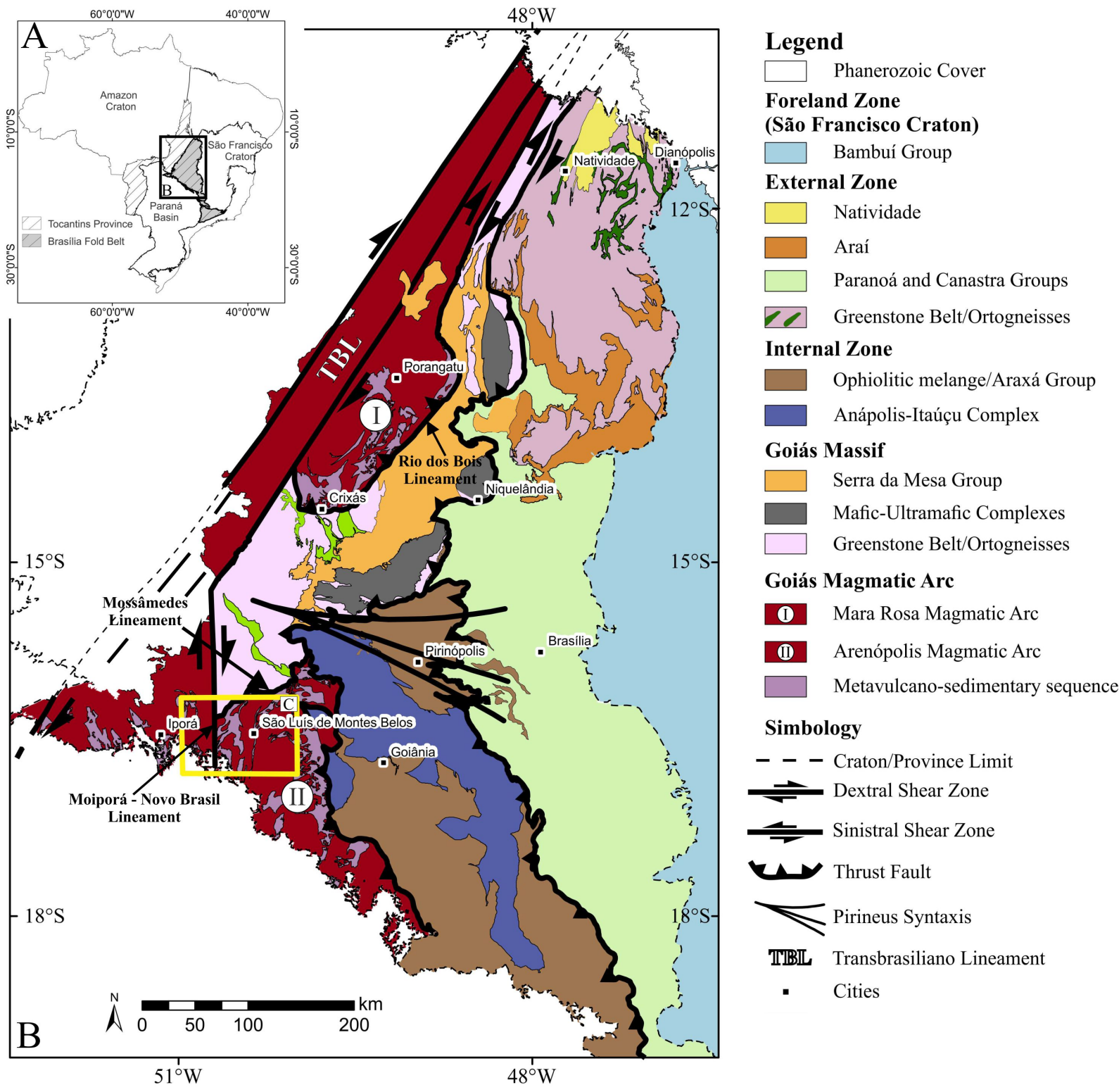

Figura 1 - A) Província Tocantins, destaque para a Faixa Brasília B) Mapa geológico simplificado da Faixa Brasília (modificado de Pimentel et al., 2004; Fuck et. al., 2014 e Praxedes, 2015). C) Local da figura 2A. 


\subsection{Arco Magmático Arenópolis (AMA)}

As unidades supracrustais e ortognáissicas, juvenis ocorrem justapostas por zonas transcorrentes com direções NNE a NNW, pertencentes ao Lineamento Transbrasiliano (Pimentel et al., 2000). Dados isotópicos obtidos por métodos $\mathrm{Rb}-\mathrm{Sr}$, $\mathrm{Sm}-\mathrm{Nd}$ e principalmente por U-Pb em zircão, indicam quatro intervalos principais de cristalização das rochas das unidades supracrustais e ortognáissicas do AMA (Tabela 1). O primeiro ocorreu entre 900 e 800 Ma, responsável pela formação das unidades ortognáissicas Arenópolis, Sanclerlândia e Iporá, e das sequências metavulcanossedimentares Arenópolis, Córrego da Boa Esperança e Anicúns-Itaberaí (Pimentel et al., 1991; Pimentel e Fuck 1994; Laux et al. 2004 e Motta de Araújo, 2012). O segundo intervalo, entre 780 e 750 Ma, está registrado por gnaisses milonitizados Creoulus e Lavrinha, granitoides Jaupaci do tipo TTG e sequências metavulcanossedimentares Jaupaci e Bom Jardim (Guimarães et. al., 2012; Laux et. al., 2004 e Marques et. al. 2016). O terceiro episódio, entre 670 e 600 Ma, constitui período de intensa atividade ígnea e alojamento de unidades ortognáissicas Matrinxã, Turvânia e Choupana e intrusões máfico-ultramáficas da Suíte Americano do Brasil (Gioia 1997; Laux et. al., 2004 e 2005; Nilson et. a. 1997; Pimentel et. al. 1991; Pimentel e Fuck 1994) e Santa Bárbara (Silva F.O. 1991).

Um conjunto de intrusões tardi - a - pós-tectônicas de granitos cálcio-alcalinos ricos em potássio com idades entre 620 e $485 \mathrm{Ma}$, ocorrem ao longo do AMA. Esse conjunto de intrusões compõe o quarto evento principal ocorrido no AMA. (Pimentel et. al. 1991; Pimentel et. al. 1996; Laux et. al. 2004 e Motta de Araújo 2012).

\subsection{Geologia da região Mossâmedes - Moiporá}

Na região entre Mossâmedes e Moiporá as zonas de cisalhamento Firminópolis, São Luís de Montes Belos (zc SLMB), Mossâmedes e Moiporá - Novo Brasil (zc MNB) definem quatro blocos com idades média, geoquímica e repostas magnéticas distintas. Na figura 2 A os blocos foram definidos de leste para oeste como bloco Turvânia, Sanclerlândia, Uvá e Novo Brasil e suas características estão sumarizadas nos tópicos a seguir. 
Tabela 1 - Sumário de idades das rochas do Arco Magmático 1 - Pimentel et al., 1991; 2 - Pimentel e Fuck, 1994; 3 Pimentel et al., 1996; 4 - Gioia, 1997; 5 - Nilson et al., 1997; 6 - Pimentel et al., 2003; 7 - Laux et al., 2004; 8 Laux et al., 2005; 9 - Guimarães et al., 2012; 10 - Motta de Araújo, 2012; 11 - Marques et al., 2016. OU = Unidade Ortognaissica (Ortogneiss Unit), MVSS = Sequencia Metavulcanossedimentar (Metavulcano Sedimentary Sequence), MUM = Máfico - Ultramáfico, AGS = Suíte Aragoiânia (Aragoiânia Suite) e SNS = Suíte granítica Serra Negra (Serra Negra Suite).

\begin{tabular}{|c|c|c|c|c|c|c|c|c|}
\hline \multicolumn{9}{|c|}{ Arco Magmático Arenópolis } \\
\hline \multicolumn{9}{|c|}{$1^{\circ}$ Evento - 900 e 800} \\
\hline & Unidade & Associação & $\begin{array}{c}\text { Idade (Ma) } \\
\text { - U-Pb } \\
\text { Zircão }\end{array}$ & $\begin{array}{c}\text { Idade (Ma) - } \\
\text { Sm-Nd }\end{array}$ & $\begin{array}{l}\text { Idade (Ga) - } \\
\text { TDM Sm-Nd }\end{array}$ & $\varepsilon_{\mathrm{Nd}}(\mathrm{T})$ & $\begin{array}{l}\text { Idade } \\
\text { (Ma) - } \\
\text { K-Ar }\end{array}$ & $\begin{array}{l}\text { Idade } \\
(\mathrm{Ma})- \\
\mathrm{Rb}-\mathrm{Sr}\end{array}$ \\
\hline \multirow{3}{*}{$\mathrm{OU}$} & Arenópolis & Granito-Gnaisse & $899 \pm 7^{1}$ & & & +1.9 to $+3.2^{1}$ & & $818 \pm 57^{1}$ \\
\hline & Sanclerlândia & $\begin{array}{l}\text { Orthognaisse } \\
\text { Tonalítico }\end{array}$ & $822 \pm 7^{10}$ & 0.9 to $1.44^{4 \mathrm{e} 10}$ & +4 to $+6^{11}$ & $+0.3^{7}$ & & $940^{2}$ \\
\hline & Iporá & Biotita Gnaisse & $804 \pm 6^{7}$ & & $1.18^{7}$ & $+0.3^{7}$ & & \\
\hline \multirow{3}{*}{ MVSS } & Arenópolis & Meta-riolito & $890 \pm 8^{1}$ & & 0.9 to $1.2^{1}$ & +2.5 to $+2.8^{1}$ & & \\
\hline & $\begin{array}{l}\text { Córrego da Boa } \\
\text { Esperança }\end{array}$ & Xisto anfibolítico & $862 \pm 5^{7}$ & & 0.94 to $1.1^{7}$ & +4.4 to $+5.5^{7}$ & & \\
\hline & Anicúns-Itaberaí & Metagabbro & $815 \pm 10^{7}$ & & 0.94 to $1.12^{7}$ & +4.1 to $+4.4^{7}$ & & \\
\hline \multicolumn{9}{|c|}{$2^{\circ}$ Evento $780-750 \mathrm{Ma}$} \\
\hline \multirow{4}{*}{$\mathrm{OU}$} & Creoulos Granite & Muscovita Gnaisse & $784 \pm 14^{8}$ & & 1.07 to $1.47^{8}$ & -1.8 to $+3.6^{8}$ & & \\
\hline & $J=\cdot \mathrm{D}$ & Metatonalito & $770 \pm 8^{11}$ & & $0.86^{11}$ & $+5.41^{11}$ & & \\
\hline & Jaupaci Defl & Metatrondhjemito & $753 \pm 12^{11}$ & & $1.26^{11}$ & $+4.61^{11}$ & & \\
\hline & Lavrinha Granite & Granito milonítico & $748 \pm 4^{8}$ & & $0.89^{8}$ & $+4.8^{8}$ & & \\
\hline MVSS & Bom Jardim & Vulcânica ácida & $749 \pm 6^{9}$ & & 1.0 to $1.1^{9}$ & +1.0 to $+4.6^{9}$ & & \\
\hline \multicolumn{9}{|c|}{$3^{\circ}$ Evento $670-625$} \\
\hline \multirow{6}{*}{$\mathrm{OU}$} & Matrinxã Gneiss & Metagranitóide & $669 \pm 3^{8}$ & & $0.99^{8}$ & $+2.2^{8}$ & & $895^{2}$ \\
\hline & Granito Choupana & Metagranodiorito & $662 \pm 12^{8}$ & & 1.06 to $1.09^{8}$ & +1.7 to $+2.8^{8}$ & & \\
\hline & Palminópolis & Biotita gnaisse & $637 \pm 20^{8}$ & & 0.98 to $2.27^{8}$ & $-0.61^{8}$ & & \\
\hline & Turvânia & Biotita gnaisse & $630 \pm 5^{8}$ & & 0.99 to $1.11^{8}$ & +0.3 to $+1.9^{8}$ & & \\
\hline & Iporá-Amorinópolis & Meta-riolito & $636 \pm 6^{1}$ & & 1.0 to $1.1^{1}$ & +0.3 to $5^{1}$ & & \\
\hline & Firminópolis & Hornblenda gnaisse & $634 \pm 8^{8}$ & & 1.1 to $1.4^{8}$ & $-1.7^{4}$ & & \\
\hline \multirow{4}{*}{ MUM } & Americano do Brasil & Norito & $626 \pm 8^{7}$ & $612 \pm 66^{5}$ & & +2.4 to $+3.1^{4 \mathrm{e} 5}$ & $610 \pm 50^{4}$ & $620 \pm 10^{5}$ \\
\hline & Mangabal & & & & & & $612 \pm 8^{4}$ & \\
\hline & Córrego Seco & Diorito & $623 \pm 13^{7}$ & & $1.05^{7}$ & +1.8 to $+1.11^{7}$ & & \\
\hline & Santa Bárbara & Anortosito & $598 \pm 8^{7}$ & & $1.25^{7}$ & +2.2 to $+2,5^{7}$ & & \\
\hline \multicolumn{9}{|c|}{$4^{\circ}$ Evento $620-485$} \\
\hline MVSS & Jaupaci & Meta-riolito & $574 \pm 10^{11}$ & & $1.1^{11}$ & $+1.19^{11}$ & & \\
\hline \multirow{3}{*}{ AGS } & Farturinha Granite & Biotita Granito & $614 \pm 5^{8}$ & & $1.0^{8}$ & $+4.5^{8}$ & & \\
\hline & Buriti de Goiás & Biotita Granito & $614 \pm 20^{10}$ & & 0.97 to $1.19^{10}$ & +1.2 to $+2.7^{10}$ & & \\
\hline & Mossamedes Granite & Biotita Granito & $548 \pm 11^{10}$ & & $0.93^{10}$ & $+2.57^{10}$ & & \\
\hline \multirow{7}{*}{ SNS } & Rio Caiapó & Granodiorito & & & & & & $588 \pm 19^{3}$ \\
\hline & Serra do Iran & Biotita Granito & & & & & & $588 \pm 19^{3}$ \\
\hline & Ivolândia Granite & Biotita Granito & $556 \pm 5^{10}$ & & $1.34^{10}$ & $-3.2^{10}$ & & \\
\hline & Messianópolis & Biotita Granito & $542 \pm 4^{10}$ & & $2.25^{10}$ & $-20^{10}$ & & \\
\hline & Pilolândia Granite & Granito Milonítico & $532 \pm 8^{10}$ & & 1.12 to $1.27^{10}$ & -1 to $-2.2^{10}$ & & \\
\hline & Iporá Granite & Biotita Granito & $511 \pm 6.9^{12}$ & & & & & $490 \pm 24^{1}$ \\
\hline & Serra Negra Granite & Biotita Granito & $506 \pm 3.6^{12}$ & & 1.23 to $1.5^{7}$ & -3 to $-4^{7}$ & & \\
\hline
\end{tabular}




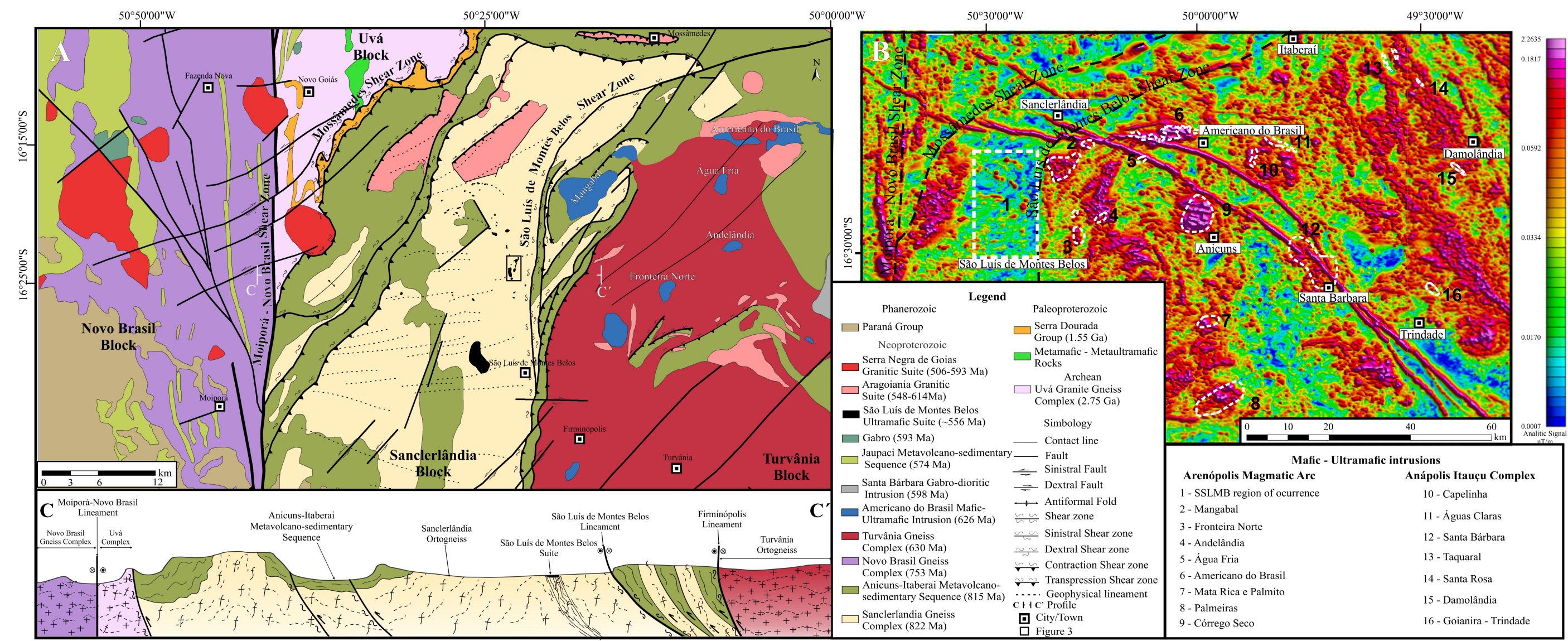

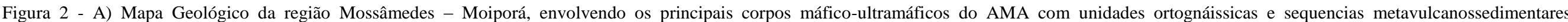

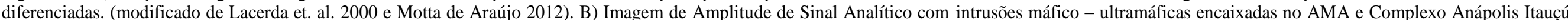
(Modificado de Mota e Silva 2011). C) Perfil geológico esquemático. 


\subsubsection{Bloco Turvânia}

O bloco Turvânia é composto pela Suíte máfico-ultramáfica Americano do Brasil encaixados na unidade ortognáissica Turvânia. A suíte máfico-ultramáfica é constituída por corpos máficos (gabros e gabronoritos) - ultramáficos (piroxenitos, peridotitos e dunitos) acamadados, com mineralização, associadas a sulfetos, de $\mathrm{Ni}, \mathrm{Cu}$ e EGP (Candia 1983; Nílson et. al. 1986; Mota e Silva et. al. 2011). Estes corpos possuem idade de $626 \pm 8 \mathrm{Ma}$ (Laux et al., 2004), $\varepsilon_{\mathrm{Nd}}(\mathrm{T}) \mathrm{de}+2.4$ (Gioia, 1997 - Tabela 1) e características de um magma parental toleítico, com cristais de olivina ( $\left.\mathrm{Fo}_{78-88}\right)$, indicando composição de um magma primitivo. A suíte Americano do Brasil está encaixada em hornblenda-epidoto gnaisse e biotita gnaisse pertencentes à unidade ortognáissica Turvânia, com composição variando de diorítica a tonalítica, idade de 630 $\pm 5 \mathrm{Ma}$ e $\varepsilon_{\mathrm{Nd}}$ variando de $-1.7 \mathrm{a}+1.9$ (Tabela 1 ). Os gnaisses são derivados de protólitos ígneos metaluminosos, com composição variando de cálcica a cálcio alcalinas propriedades semelhantes ao ortognaisse Sanclerlândia (Laux et. al. 2005; Pimentel e Fuck 1986).

\subsubsection{Bloco Sanclerlândia}

A Suíte ultramáfica São Luís de Montes Belos (SSLMB - descrita em detalhe no item 5) está intrudida nas unidades ortognáissica Sanclerlândia e sequência metavulcanossedimentar Anicúns-Itaberaí (Fig. 2) com idades U-Pb de $822 \pm 7 \mathrm{Ma}$ (Motta de Araújo, 2012) e 815 10 Ma (Laux et.al., 2004 - Tabela 1), respectivamente.

Os ortognaisses da unidade Sanclerlândia possuem variação composicional entre tonalítica, diorítica e granodiorítica metamorfizadas em fácies anfibolito e paragênese mineral composta por quartzo, plagioclásio (An 50-70\%), hornblenda, biotita e epidoto. Localmente apresentam textura e estrutura de intensa deformação, como textura milonítica e estrutura migmatítica. Elementos maiores e menores sugerem que os protólitos ígneos dos gnaisses eram metaluminosos, cálcicos a cálcio-alcalinos, com baixas concentrações de potássio, comparáveis a granitoides do tipo $\mathrm{M}$, típicos de arcos de ilha intra-oceânico (Pimentel et al., 1996). 
A sequência metavulcanossedimentar Anicúns-Itaberaí é composta por duas unidades: unidade metavulcânica máfico-ultramáfica e unidade metassedimentar, ambas metamorfisadas em fácies xisto verde a anfibolito. A unidade máfico-ultramáfica é formada por epidoto - anfibolitos, granada - anfibolitos, biotita-clorita - xistos, sericitaquartzo-clorita - xistos, talco-clorita - xistos, epidoto - clorita - muscovita - quartzo hornblenda - xistos, tremolita - actinolita - xistos, clorititos e talco - clorita - antofilita xistos. A unidade sedimentar é representada por granada - mica - xistos feldspáticos, cianita-quartzo - xistos, sericita-clorita-quartzo - xistos, quartizitos micáceos, metassedimentos síltico - argilosos, quartzitos ferruginosos, quartzitos manganesíferos, mármores calcíticos, metacherts e grafita xistos (Baêta Júnior e Moreton, 1999).

\subsubsection{Bloco Uvá}

O Bloco Uvá compreende o complexo Uvá e greenstone-belt sotopostos por metassedimentos do Grupo Serra da Mesa com idade máxima de sedimentação de 1,55 Ga (Marques, 2009), pertencentes ao Maciço do Goiás. O complexo Uvá é composto por gnaisses diorítico, tonalítico e granodiorítico com idade de 2,93 Ga e metatonalito, metamonzonito e metagranodiorito de idade 2,75 Ga (Jost et al., 2005).

\subsubsection{Bloco Novo Brasil}

O bloco Novo Brasil (570-770 Ma), limitado a leste com o bloco Sanclerlândia pelo TBL, é constituído pelas unidades ortognaíssica Matrinxã a sul e o cinturão Jaupaci

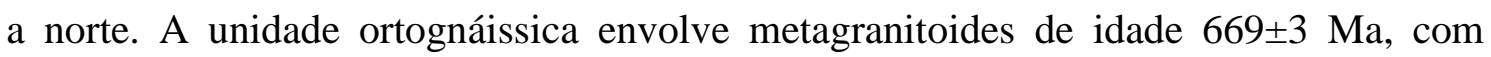
composição variando de tonalítica a granodiorítica (Laux et al., 2005 - Tabela 1). As concentrações de elementos maiores e menores são comparáveis aos ortognaisses Sanclerlândia e Turvânia, porém, os protólitos das rochas da unidade Matrinxã são comparáveis a granitos do tipo I e M (Pimentel e Fuck, 1986). O cinturão Jaupaci compreende ortognaisses e uma sequência metavulcanossedimentar. Os ortognaisses compreendem dois tipos de metagranitoides petrograficamente distintos: (i) ilmenitametagranitoides, com composição variando de tonalito a granodiorito, intensamente foliados e idade U-Pb em zircão de $770 \pm 8$ Ma (Marques et al., 2016 - Tabela 1); (ii) magnetita-metagranitoides com composição variando de trondhjemito a granito, intensamente foliados com porções milonitizadas e idade U-Pb de $753 \pm 12 \mathrm{Ma}$ (Marques et al., 2016 - Tabela 1). A sequência vulcanossedimentar é composta por 
basaltos e riolitos metamorfisados com idade final de atividade vulcânica de $574 \pm 10$ Ma (Marques et al., 2016 ).

\subsubsection{Intrusões Graníticas sin a pós - tectônicas}

Ao longo de todos os blocos neoproterozoicos e arqueano ocorrem intrusões de granitos alcalinos ricos em potássio pertencentes às Suítes graníticas Aragoiânia e Serra Negra de Goiás (SSN). A SSN é composta por granitoides com composição variando de granítica a granodiorítica, com paragênese mineral composta por biotita e feldspato potássico e idade de cristalização entre 593 e 506 Ma (Laux et al., 2005 e Marques et al., 2016 - Tabela 1). O grau de deformação nessas rochas é predominantemente baixo com intrusões geralmente isentas de deformação, apesar de algumas serem intensamente deformadas apresentando textura de ultramilonito (Marques et al., 2016; Motta de Araújo 2012 e Pimentel et. al. 1996). A Suíte Aragoiânia é constituída por granitos sin a pós-tectônicos pouco deformados com idades U-Pb em zircão variando de 614 a 548 Ma e $\varepsilon N d$ variando de +1.2 a +4.5 (Laux et. al., 2005 e Motta de Araújo, 2012 - Tabela 1).

\section{Métodos}

A aquisição de dados para a caracterização das rochas da SSLMB foi feita a partir de trabalhos de campo, os quais envolveram estudos detalhados de amostras de afloramentos e furos de sonda, disponibilizados pela Brasil Minérios S.A.. A petrografia foi desenvolvida a partir da análise de trinta e oito seções polidas e em quatro mounts de vermiculita. As imagens de elétrons retroespalhados (backscattered electron) foram obtidas em microscópio eletrônico de varredura dos laboratórios de microssonda eletrônica e de geocronologia do Instituto de Geociências da Universidade de Brasília (IG-UnB).

Além de petrografia detalhada, foram realizadas análises de química mineral, litogeoquímica e isótopos instáveis (pelos métodos $\mathrm{Sm}-\mathrm{Nd}$ em rocha total e U-Pb em grãos de titanita). Para os procedimentos utilizados na obtenção de dados de litogeoquímica e $\mathrm{Sm}-\mathrm{Nd}$ em rocha total, as rochas foram pulverizadas em panela de ágata. 


\subsection{Química Mineral}

Dezenove seções polidas e quatro mounts de vermiculita foram analisados em Microssonda Eletrônica (EPMA - Electron Probe Microanalyser) do Instituto de Geociências da Universidade de Brasília (IG-UnB), modelo JEOL JXA-8230, operando com aceleração de $15 \mathrm{Kv}$, feixe de corrente de $10 \mathrm{nA}$ e tempo de contagem de 20 segundos. As lamelas de vermiculita foram separadas a mão e arranjadas em mounts com resina epoxy em uma sala a temperatura de $17^{\circ} \mathrm{C}$. Foram utilizados os detectores de Dispersão de Energia (EDS - Energy Dispersive Spectrometry), que fornece análises qualitativas e semi-quantitativas, assim como de Dispersão por Comprimento de Onda (WDS - Wavelength Dispersive Spectrometer), que fornece análises quantitativas. Padrões naturais e sintéticos de óxidos e silicatos foram utilizados para concentração dos elementos em cada grão dos minerais. Valores de $\mathrm{H}_{2} \mathrm{O}, \mathrm{Fe}_{2} \mathrm{O}_{3}, \mathrm{FeO}, \mathrm{Fe}^{3+}$ e $\mathrm{Fe}^{2+}$ foram estimados a partir de cálculos com base na estrutura química de cada mineral. Análises WDS foram obtidas para flogopita (Mg-biotita), vermiculita, anfibólios, clinopiroxênios, olivina e titanita.

\subsection{Litogeoquímica}

As concentrações de elementos maiores e menores foram determinadas para 3 amostras de afloramentos e 6 amostras de furo de sonda, com procedimento realizado em dois laboratórios. No laboratório Bureau Veritas Mineral foram analisadas 6 amostras de afloramento e 5 de três furos de sonda (FS17, FS101 e FS123), utilizando o método de caracterização de rocha total (código LF200 e AQ200), incluindo o total de carbono e enxofre (código TC000), com 44 elementos obtidos por ICP-MS (Inductively Coupled Plasma - Mass Spectrometry) e 14 elementos obtidos por ICP-ES (Inductively Coupled Plasma - Emission Spectroscopy). A descrição completa do método pode ser encontrada no site da Bureau Veritas Mineral Laboratories (http://acmelab.com/).

Os furos de sonda (FS19, FS33 e FS90) foram analisados no laboratório SGS Geosol LTDA. O procedimento consistiu na fusão de metaborato de lítio (código ICP95A), incluindo o teste de perda ao fogo (LOI - Loss On Ignition) (código FAI515). As concentrações dos elementos foram determinadas tanto por ICP-MS, quanto por 
ICP-ES. A metodologia utilizada está detalhada no site do Laboratório Geosol (http://www.sgsgroup.com.br/pt-BR/Mining.aspx).

\subsection{Análises U-Pb}

O procedimento adotado para a obtenção dos dados geocronológicos de $\mathrm{U}-\mathrm{Pb}$ foi realizado de acordo com descrito em Bühn et. al. (2009). Os resultados foram obtidos por LA-ICP-MS (Laser Ablation - Inductively Coupled Plasma Mass Spectrometry), um equipamento de ablação a laser acoplado ao espectrômetro de massa do laboratório de Geocronologia do IG-UnB.

Cerca de cinco quilos de amostra foram britados e posteriormente fragmentados pelo SELFRAG (High Voltage Pulse Power Fragmentation). O produto deste processo foi dividido em frações magnéticas e não magnéticas pelo separador magnético Frantz. O concentrado não magnético foi observado em lupa binocular e deste foram selecionados os grãos de titanita mais límpidos e com estruturas cristalinas bem formadas.

Com os grãos de titanita foi montado um mount com resina epoxy, este polido e limpo em solução $\mathrm{HNO}_{3}(3 \%)$, para depois ser imageado em microscópio eletrônico por elétrons retroespalhados, modelo FEI Quanta 450 - EDAX. A etapa seguinte consistiu na introdução do mount no equipamento de ablação a laser, New-Wave UP213 Nd:YAG laser $(\lambda=213 \mathrm{~nm})$, acoplado ao ICP-MS multi-coletor Thermo Finnigan Neptune. No transporte das partículas até o espectrômetro, utilizou-se hélio (ca. $40 \mathrm{~L} / \mathrm{min}$ ) misturado a argônio (ca. 0,90 L/min) antes de atingir o plasma. O laser incidente operou com frequência de $10 \mathrm{~Hz}$, intensidade de energia variando de 2 a $3 \mathrm{~J} / \mathrm{cm}^{2}$, spot com diâmetro fixo de $30 \mu \mathrm{m}$ e tempo de ablação de 40 s.

Durante o procedimento para a obtenção dos dados foram utilizados padrões titanita Khan (522,2 — 2.2 Ma; Heaman, 2009) e zircão GJ-1 (Jackson et. al., 2004). O padrão titanita Khan foi utilizado como um padrão externo primário com a finalidade de controlar o fracionamento do ICP-MS. O fator de correção resultante considera a posição relativa de cada análise com uma sequência de quatro amostras junto de duas análises do padrão e do branco (Albarède et. al., 2004). O padrão GJ-1 foi analisado no começo e final de cada sessão e com leituras feitas a cada oito grãos analisados da amostra, permitindo uma acurácia por volta de $2 \%$ e precisão próxima a $1 \%$. Os dados 
de U-Pb foram tratados utilizando isoplot 4.15 (Ludwig, 2012), com erro expresso em 2 $\sigma$.

\subsection{Isótopos de $\mathrm{Sm}-\mathrm{Nd}$}

As análises de Sm-Nd foram executadas no Laboratório de Geocronologia do IG-UnB adotando o método descrito por Gioia e Pimentel (2000) e equipamento TIMS (Thermal Ionization Mass Spectrometry). O pó da rocha foi pesado e adicionado de traçador misto ${ }^{149} \mathrm{Sm}-{ }^{150} \mathrm{Nd}$ e, subsequentemente, diluído em soluções ácidas contendo $\mathrm{HNO}_{3}, \mathrm{HF}$ e $\mathrm{HCl}$. Os procedimentos seguintes consistiram na extração dos elementos terras raras seguido da extração dos isótopos de $\mathrm{Sm}$ e $\mathrm{Nd}$. As análises foram realizadas em espectrômetro de massa Finnigan MAT 262 em meio estático. Incertezas para as razões $\mathrm{Sm} / \mathrm{Nd}$ e ${ }^{143} \mathrm{Nd} /{ }^{144} \mathrm{Nd}$ são em torno de $\pm 0.5 \%$ (2 $\left.\sigma\right)$ e $\pm 0.005 \%$ (2 $\left.\sigma\right)$, respectivamente, com base em rochas-padrões internacionais BHVO-1 e BCR-1. O detector registra a intensidade do feixe de íons para cada massa e o resultado expressa as concentrações de $\mathrm{Sm}$ e $\mathrm{Nd}$ em $\mathrm{ppm}$ e as razões ${ }^{147} \mathrm{Sm} /{ }^{144} \mathrm{Nd}$ e ${ }^{143} \mathrm{Nd} /{ }^{144} \mathrm{Nd}$. O tratamento dos dados foi feito com isoplot 4.15 (Ludwig, 2012).

\section{Geologia Local}

\subsection{Estratigrafia e estrutura dos complexos}

A geologia da SSLMB foi primeiramente descrita pela Minebra (1974 apud Olivatti e Reis da Silva, 2008) e Silva (2006). Estes estudos forneceram as primeiras caracterizações quanto à estruturação, processos hidrotermais e alteração por intemperismo aos quais as rochas da SSLMB foram submetidas. A SSLMB é constituída por cerca de quatro dezenas de corpos elípticos intrusivos, com extensões laterais variando de 300 a 1200 metros, localizada entre as zonas de cisalhamento Moiporá-Novo Brasil e São Luís de Montes Belos (Fig. 2). As ocorrências foram delimitadas por mapeamento de detalhe, com auxílio de produtos de levantamento aerogeofísico, furos de sondagem rotativa e trado mecânico e mapeamento geoquímico de solos, realizados pela Brasil Minérios S.A. Estes corpos estão dispostos ao longo da direção ENE-WSW, a norte, e NNE-SSW, a sul, e encontram-se encaixados principalmente em ortognaisses félsicos da unidade ortognáissica Sanclerlândia. 
Os corpos Morro Pelado Norte (MPN), Morro Pelado Leste (MPL), Morro Pelado Sul (MPS) e Leonel (Fig. 3) são os maiores e mais detalhados da SSLMB, localizados a treze quilômetros na direção noroeste da cidade de São Luís de Montes Belos. Os quatro corpos são alinhados segundo a direção Norte-Sul e paralelos à zc SLMB. Estas intrusões ultramáficas foram delimitadas por uma malha densa com mais de cinco mil furos, entre sonda e trado. Porém, a maioria dos furos não atingiu a rocha maciça, perfurando apenas rochas friáveis, onde a extração de minério é viável. Portanto, embora o limite lateral esteja bem definido, o limite em profundidade não está estabelecido.

O embasamento dos corpos MPN, MPL, MPS e Leonel consiste de biotitahornblenda gnaisse tonalítico (Figs. 4A e 4B), com foliação variando de incipiente a bem pronunciada, bandamento centimétrico a decamétrico e ocasionalmente migmatítico.

As rochas da SSLMB foram intensamente afetadas por processos hidrotermais. No entanto, algumas rochas possuem textura e estrutura primárias preservadas e paragênese ígnea pouco alterada, possibilitando a distinção de peridotitos (dunito + wehrlito) e clinopiroxenito como protólitos ígneos, sugerindo uma estratigrafia ígnea (Fig. 4C). A estratigrafia consiste de camadas de dunito-wehrlito intercaladas com camadas de clinopiroxenito. As rochas hidrotermalizadas são serpentina - magnetita vermiculita - flogopitito (srp-mt-vrm-flogopitito) e vermiculita - flogopitito (vrmflogopitito), produtos de alteração dos peridotitos e clinopiroxenito, respectivamente (Fig. 4D). Em algumas porções entre peridotitos e clinopiroxenito ou seus derivados hidrotermais, ocorrem zonas constituídas por agregados de grãos grossos de olivina com corona de serpentina, ou agregados de grãos de tremolita com corona de serpentina e talco, definido como ovoides durante as atividades de exploração, em meio a uma matriz fina constituída por clinopiroxênio e flogopita (Fig. 4D). A estrutura de deformação nessas rochas é discreta, demarcada por lamelas de flogopita e vermiculita orientadas paralelas a orientação da intrusão.

As unidades ultramáficas da SSLMB são eventualmente cortadas por diques quartzo-feldspáticos, diques ultramáficos, veios preenchidos apenas por feldspato e veios de antofilita e serpentina. Os diques félsicos possuem granulação grossa a muito grossa (pegmatítica), com predominância de albita $\left(\mathrm{Ab}_{90}\right)$ associada a quartzo, sanidina $\left(\mathrm{Or}_{83}\right)$ e turmalina, e encontram-se parcial a totalmente caulinizados (Fig. 4A, 4E e 4F). Os veios são compostos por feldspato de mesma composição dos diques félsicos, porém com granulação muito mais fina. Os diques ultramáficos (doravante denominados de 
hornblenditos) possuem espessura de vinte a trinta centímetros e são constituídos predominantemente por grãos de hornblenda (70\%-90\% do volume). Os veios de antofilita e serpentina possuem espessura muito fina e ocorrem apenas cortando os peridotitos.

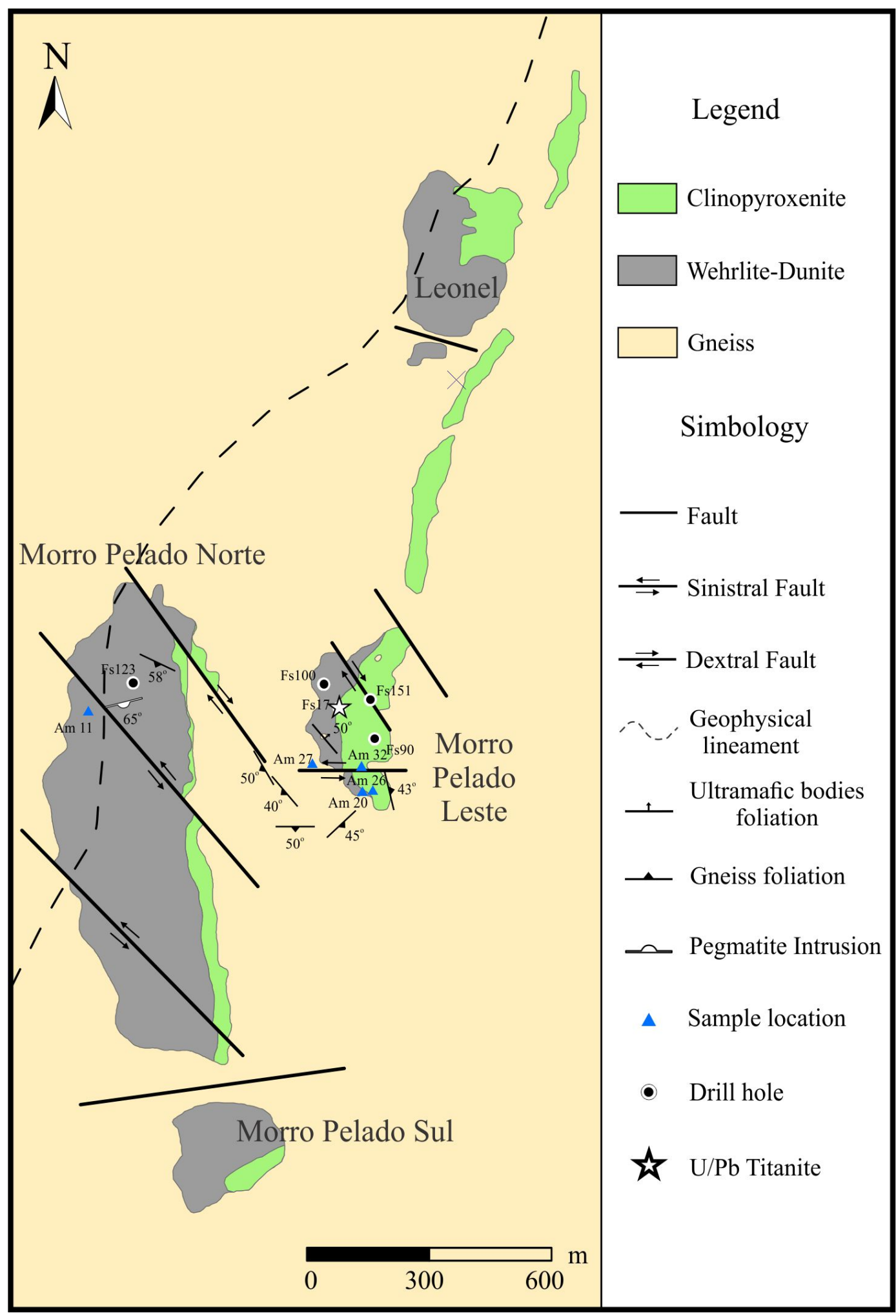

Figura 3 - Mapa geológico dos corpos Morro Pelado Norte, Morro Pelado Leste, Morro Pelado Sul e Leonel. 


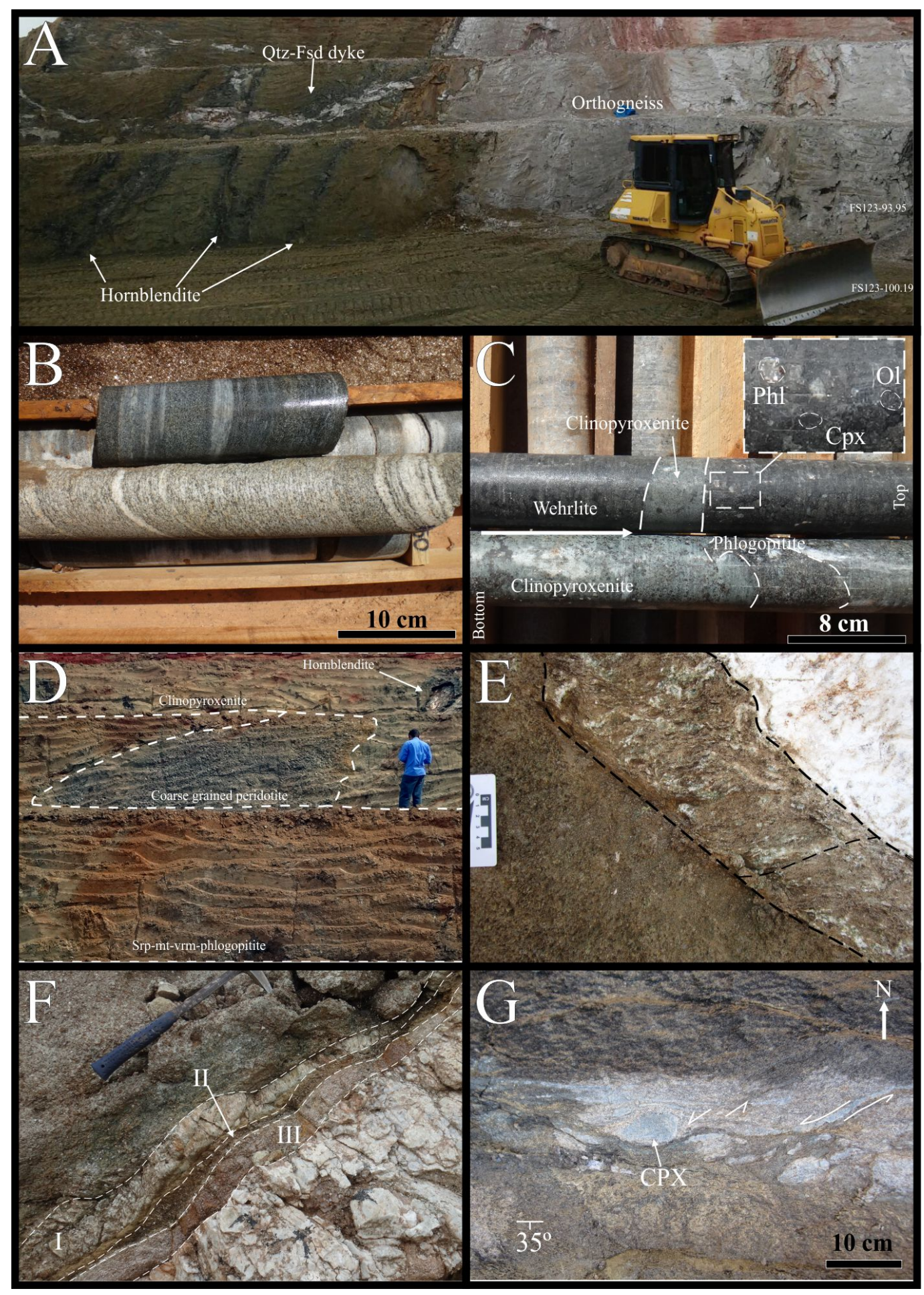

Figura 4 - A) Contato intrusivo entre vrm-flogopititito e encaixante, com destaque para intrusão pegmatítica horizontal e hornblenditos vertical (MPL). B) Furos de sondagem de biotita-hornblenda ortognaisse pertencente à unidade ortognáissica de Sanclerlândia, com foliação variando de pronunciada a suave. C) Amostra de clinopiroxenito com zona de flogopitito associada (FS 123-100.19) e amostra com intercalação entre wehrlito e clinopiroxenito fino (FS 123-93.95) (MPN). D) Frente de lavra com camada de srp-mt-flogopitito sotoposta por camada de clinopiroxenito, com ocorrência de domínio com ovoides entre as camadas. Destaque para hornblendito na porção superior à direita (MPS). E) Destaque para interface de reação entre pegmatito quartzo-feldspático encaixado em vrm-flogopitito, onde as lamelas de vermiculita e flogopita que bordejam o corpo félsico possuem orientação preferencial, enquanto que as lamelas da encaixante não possuem orientação (MPL). F) Destaque para três tipos de zona de alteração entre veio quartzo-feldspático e srp-mt-vrm-flogopititito. A zona I consiste de cristais prismáticos de antofilita, a zona II é composta somente por flogopita e vermiculita e na zona III ocorrem feldspato e quartzo de granulação média a grossa, com lamelas de flogopita e vermiculita disseminadas (MPN). F) Plano E-W com sigmoide de clinopiroxenito (CPX) incluso em flogopitito, mostrando sentido de cisalhamento sinistral (MPL). Abreviação mineral segundo Whitney e Evans (2010). 
Zonas de cisalhamento sinistrais de caráter rúptil-dúctil com orientação E-W e NW-SE, ocorrem em algumas porções cortando as intrusões ultramáficas. O movimento é evidenciado por sigmoides de clinopiroxenito em meio à vrm-flogopitito com lamelas de flogopita e vermiculita orientadas (Fig. 4G). As zonas de cisalhamento são posteriores às intrusões dos pegmatitos quartzo-feldspáticos, pois alguns diques félsicos encaixados norte-sul estão fragmentados na direção E-W. Em alguns locais do MPL, onde ocorrem essas zonas de cisalhamento, há porções das intrusões pegmatíticas félsicas e hornblendito transpostos em vrm-flogopititos, sugerindo cisalhamento posterior aos dois tipos de diques.

Nos complexos MPN e Leonel predominam srp-mt-vrm-flogopititos silicificados em superfície, com corpos peridotíticos em profundidade sobrepostos a clinopiroxenitos. A silificação chega a sustentar um morro de vinte metros de desnível, chamado Morro Pelado, localizado a noroeste do corpo MPN. Essa feição, por outro lado, não é observada nos corpos MPS e MPL, formados por rochas muito friáveis que configuram um relevo aplainado. O MPS consiste principalmente de peridotitos, dunitos e srp-mt-vrm-flogopititos não silicificados, com borda de clinopiroxenito, enquanto que no MPL predominam clinopiroxenitos e vrm-flogopititos em níveis mais superficiais, com peridotito e srp-mt-vrm flogopititos em profundidade (Fig. 3). A silicificação presente nos corpos MPN e Leonel pode estar relacionada ao lineamento detectado por produtos aerogeofísicos (Fig. 3).

\subsection{Assembléia Ígnea}

A ocorrência de dunitos é restrita nos corpos da SSLMB. Estas são rochas subfaneríticas, de coloração cinza escuro, levemente esverdeadas, magnéticas e compostas por olivina $\left(\mathrm{Fo}_{87}\right)$ como mineral ígneo reliquiar. $\mathrm{O}$ restante da mineralogia consiste dos minerais secundários serpentina, magnetita (30-35\% do volume), calcita e magnesita. Os grãos cumulus de olivina ocorrem como cristais subeuedrais, fraturados, parcialmente substituídos por serpentina e magnetita (Fig. 5A). Alguns grãos de olivina são substituídos por um agregado fino de coloração marrom, iddingsita. 


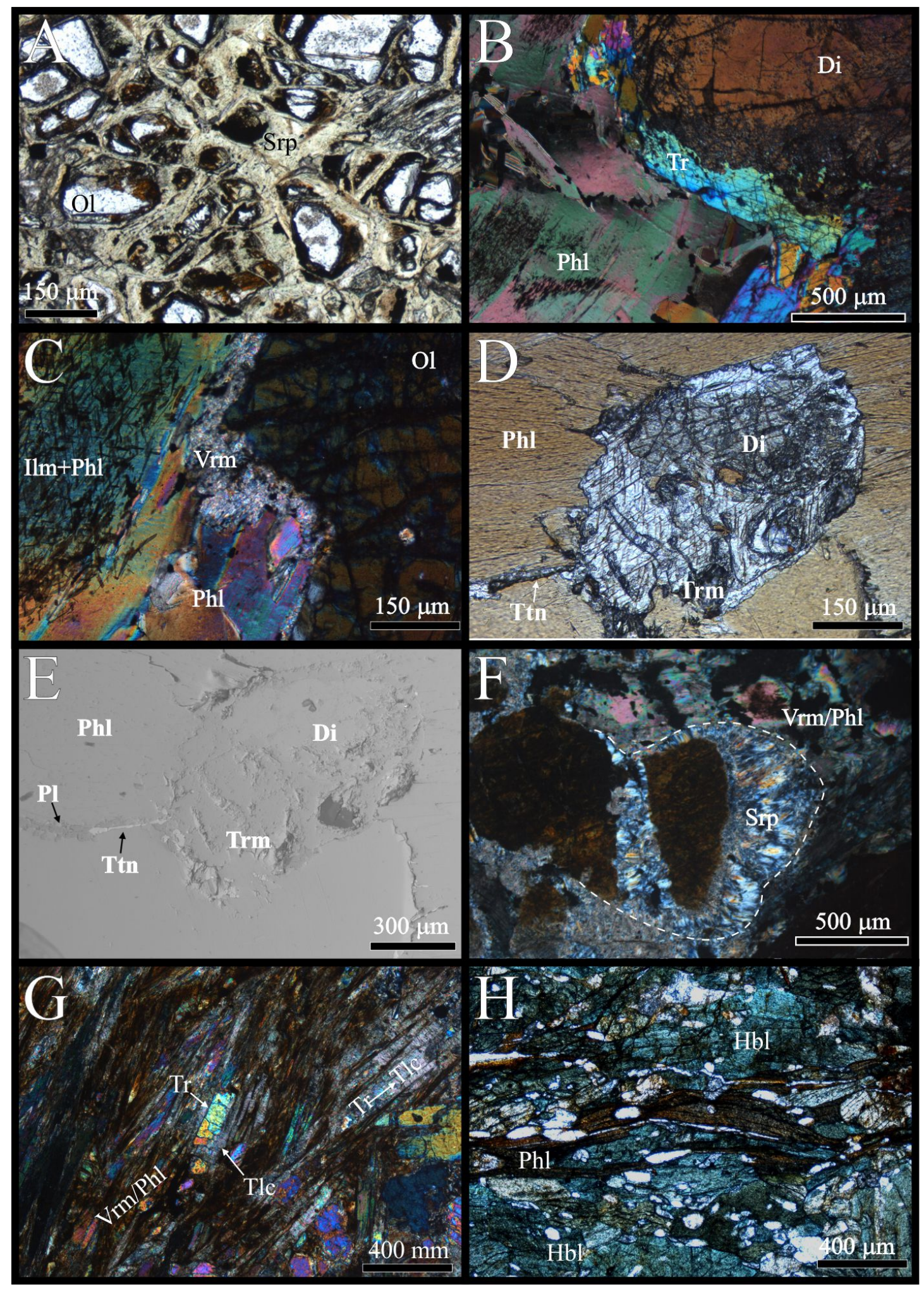

Figura 5 - A) Fotomicrografia a nicóis paralelos (NP) de dunito serpentinizado, com relictos de olivina parcialmente alterados para serpentina e magnetita (Am11). B) Fotomicrografia a nicóis cruzados (NX) da amostra FS123-93.95, com destaque para borda do grão de diopsídio alterado para tremolita. C) Fotomicrografia (NX) da amostra FS12393.95, com destaque para o contato retilíneo entre olivina e flogopita zonada com inclusões de ilmenita (sagenítica) no núcleo e borda da lamela sem inclusões. Destaque também para borda da flogopita alterando para vermiculita. D) e E) Fotomicrografia (NP) e imagem de BSE, respectivamente, com destaque para processo de alteração de clinopiroxênio para tremolita e neoformação de flogopita, titanita e plagioclásio (FS17-28,65m). F) Fotomicrografia (NX) de pseudomorfo de olivina com núcleo substituído por iddingsita e corona de lamelas de serpentina em meio a uma matriz composta por hidroflogopita (FS100). G) Fotomicrografia (NX) de cristais prismáticos de tremolita, com alteração para talco, cercada de vermiculita e flogopita. Fotomicrografia pertencente à parte de ovoide que ocorre na zona entre rochas peridotíticas e piroxeníticas (Am 17d). H) Grãos de hornblenda e flogopita orientados em dique ultramáfico (Am20) (NP). Abreviação mineral segundo Whitney e Evans (2010). 
Wehrlito compreende rochas de coloração cinza escuro mosqueado (Fig. 4C), compostas por olivina, diopsídio e flogopita como minerais ígneos primários. Essas rochas constituem camadas de 3 metros no MPL e de 20 a 100 metros no MPS e MPN. Olivina $\left(\mathrm{Fo}_{86}\right)$ ocorre como grãos de granulação média, com fraturas preenchidas por serpentina e iddingsita, e margens parcialmente substituídas por lamelas de serpentina e magnetita muito finas, caracterizando uma corona. Cerca de $20 \%$ da rocha é composta por cristais tabulares de diopsídio (En 50\%), geralmente alterados para tremolita (Fig. 5B). As lamelas de flogopita são anédricas, de coloração marrom avermelhada e apresentam exsoluções em asterisco de agulhas de ilmenita no núcleo, caracterizando textura sagenítica; nas bordas, as lamelas de flogopita apresentam mesmas características cristalográficas e composição química, porém sem exsoluções (Figs. 5B e 5C) (doravante denominadas de flogopita sagenítica). Algumas lamelas de flogopita possuem alteração para vermiculita apenas na borda conforme observado na figura $5 \mathrm{C}$.

Camadas de clinopiroxenito de granulação fina ocorrem em profundidades superiores a 100 metros (Fig. 4C). Cristais finos e tabulares de diopsídio (En 47\%) possuem coloração verde pálida e estão parcialmente substituídos por tremolita ou actinolita. Os grãos de actinolita e tremolita são anédricos, de coloração verde clara a incolor, e ocorrem apenas alterando cristais de clinopiroxênio (Figs. 5D e 5E). Titanita, plagioclásio, pirita e carbonato são variavelmente distribuídos nestas rochas. Cerca de 30 a $50 \%$ dessa rocha é formada por lamelas de flogopita de cor laranja amarronzada e extinção picotada, que ocorrem tanto em equilíbrio com os grãos de clinopiroxênio quanto como produto de substituição desses (Figs. 5D e 5E). Associados aos grãos de diopsídio e lamelas de flogopita, ocorrem cristais anédricos finos a muito finos de titanita e plagioclásio (Ab 94\%) (Figs. 5D e 5E). Veios de carbonato podem ocorrer cortando a rocha e grãos de pirita euédricos de granulação fina ocorrem apenas em algumas rochas com baixas concentrações de flogopita. Clinopiroxenito também ocorre em meio a camadas de peridotito, porém com granulação mais fina.

\subsection{Assembléia Hidrotermal}

Srp-mt-vrm-flogopititos são rochas de granulação média, com coloração variando de verde claro a verde azulado, magnéticas, com textura cúmulus de olivina intensamente alterados, em meio a uma matriz composta por lamelas de hidroflogopita 
(i.e., interestratificado de vermiculita/flogopita; 80-100\% do volume) (Fig. 5F). Os pseudomorfos de olivina podem exibir núcleo completamente substituído por iddingsita, com borda de serpentina (Fig. 5F), ou núcleo totalmente substituído por serpentina e borda de talco. Nas zonas entre as rochas peridotíticas e piroxeníticas, os ovoides podem ter até 5 centímetros de diâmetro e são constituídos por pseudomorfos de olivina com borda de serpentina; ou agregados de tremolita com talco e hidroflogopita. Nos ovoides constituídos por tremolita, talco e hidroflogopita, os grãos de tremolita são aciculares, com granulação fina, parcialmente alterados para talco e dispostos em padrão radial. Cristais de magnetita parcialmente martitizada são distribuídos de forma disseminada ao longo do srp-mt-vrm - flogopitito.

Vrm-flogopitito ocorre como zonas constituídas predominantemente por flogopita de coloração vermelho - escura (> 60\% volume) e vermiculita bronze. Restitos finos a médios de clinopiroxênio com núcleo preservado e borda alterada para tremolita ocorrem ocasionalmente. Ao microscópio, as lamelas de flogopita possuem coloração laranja amarronzada. Cristais intersticiais de titanita, plagioclásio e carbonato são anedrais de granulação muito fina e mais comuns do que em clinopiroxenitos. Não há ocorrência de sulfetos.

\subsection{Diques Félsicos e Hornblenditos}

As intrusões félsicas pegmatíticas desenvolvem diferentes interfaces de reação nos diferentes litotipos. Ao redor de corpos pegmatíticos que cortam vrm-flogopititos, ocorrem lamelas de vermiculita e flogopita radialmente orientadas, diferente das lamelas sem orientação preferencial presentes na matriz da rocha hospedeira da intrusão (Fig. 4E). Quando encaixados em srp-mt-vrm-flogopititos, três zonas de reação distintas são geradas (Fig. 4F): i) zona constituída por grãos prismáticos de antofilita e serpentina; ii) zona composta por lamelas vermelho-escuras de flogopita e lamelas bronze de vermiculita; e iii) zona formada por grãos de granulação média a grossa de quartzo e feldspato, com vermiculita e flogopita disseminadas.

Dois tipos de hornblendito cortam os corpos da SSLMB: (i) O dique é constituído por cristais finos a médios de hornblenda (70\% do volume), flogopita (15\% do volume), titanita, flúor - apatita e epidoto. Os cristais de hornblenda possuem coloração verde amarronzado a verde azulado ao microscópio, as lamelas de flogopita 
são finas e estão disponibilizadas ao longo de um plano com direção preferencial (Fig. 5H). Os cristais de titanita, apatita e epidoto possuem granulação fina e são intersticiais; (ii) O dique é constituído por hornblenda ( $98 \%$ do volume) e flúor - apatita. Os critais de hornblenda possuem granulação grossa, coloração variando de amarelo pálido a verde amarronzado e em alguns hornblenditos, a hornblenda é totalmente substituída por actinolita. Os grãos de apatita ocorrem disseminados.

\subsection{Vermiculita}

Os corpos ultramáficos da SSLMB são mineralizados a dois tipos de vermiculita, formadas a partir de lamelas de flogopita de protólitos distintos, associados a três tipos de ocorrência. As lamelas de vermiculita dos srp-mt-vrm - flogopititos possuem coloração prateada (Fig. 6A) e ocorrem associadas à flogopita sagenítica (Figs. 6B e 6C). Grãos de magnetita ocorrem disseminados por toda rocha e, quando em contato com a hidroflogopita, produzem uma coloração verde-azulada (Fig. 6C) com concentração média de $0,2 \%$ de $\mathrm{K}_{2} \mathrm{O}$. A concentração de lamelas disseminadas de vermiculita permanece constante ao longo de toda a extensão do litotipo, em qualquer profundidade.

As lamelas de vermiculita em vrm-flogopititos possuem coloração bronze (Fig. 6D) e ocorrem associadas a lamelas de flogopita. As ocorrências destas, assim como da vermiculita em peridotitos, é constante a qualquer profundidade. As lamelas de hidroflogopita estão dispostas ao longo da direção N-S ou NE-SW, paralelas ao lineamento São Luís de Montes Belos.

O terceiro tipo de ocorrência ocorre em halos de alteração associados às intrusões pegmatíticas quartzo-feldspáticas encaixadas em peridotitos e seus derivados hidrotermais (Fig. 4F). Essas lamelas ocorrem interestratificadas a flogopita.

\section{Química Mineral}

\subsection{Olivina}

Cristais primários de olivina reliquiar estão preservados em apenas algumas porções dos corpos ultramáficos. Estes possuem elevado teor de $\mathrm{Mg}$ (Fo $\left.{ }_{83,29-87,18}\right)$, 
indicando magmas primitivos com teores de Ni entre 2011 e 3332 ppm (Tabela 2), comparáveis a olivinas de sistemas magmáticos sem segregação de sulfetos.

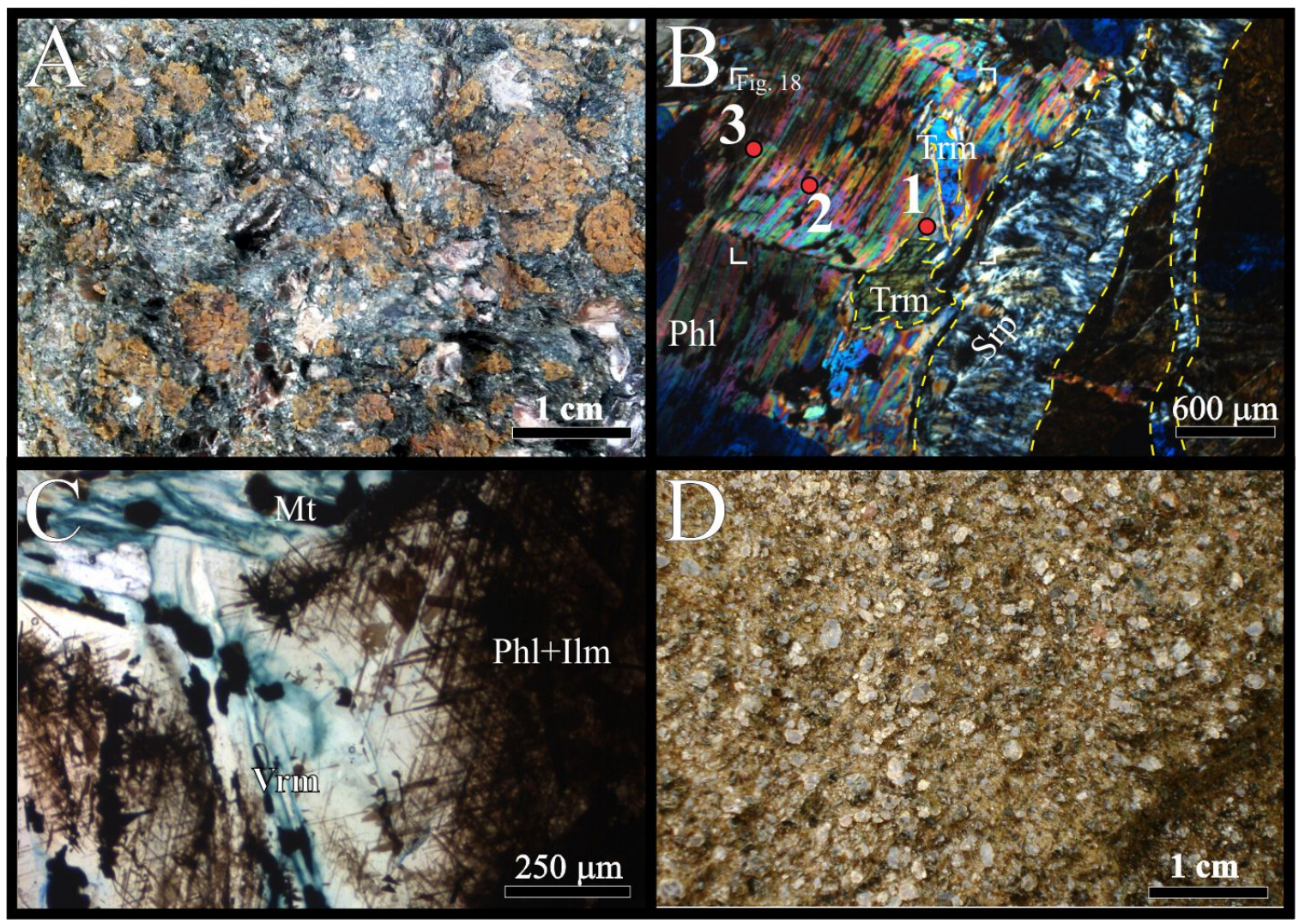

Figura 6 - A) Srp-mt-vrm-flogopitito com pseudomorfos de olivina totalmente substituídos por iddingsita em meio a uma matriz de hidroflogopita azul-prateada. B) Fotomicrografia (NX) da amostra de wehrlito, com destaque para a lamela de flogopita alterada para vermiculita (FS101). Pontos 1, 2 e 3 referem a análises feitas por microssonda eletrônica FS101-III CIV_1, FS101-III CIV_2 e FS101-III CIV_3, respectivamente. Área da figura 18 destacada. C) Destaque para reação entre grãos de magnetita e lamelas de vermiculita/flogopita com grande quantidade de inclusões de ilmenita (NP). D) Vermiculita de cor bronze em vrm-flogopitito. Abreviação mineral segundo Whitney e Evans (2010).

\subsection{Clinopiroxênio}

Análises representativas dos cristais de diopsídio encontram-se na Tabela 3. Teores relativamente elevados de $\mathrm{Cr}_{2} \mathrm{O}_{3}\left(0,17\right.$ - 0,33\%) e $\mathrm{TiO}_{2}(0,22-0,90 \%)$, dos grãos de diopsídio do vrm-flogopitito da amostra FS17 - 28,65m e do wehrlito da amostra FS123 - 93,95m, sugerem ser os cristais de clinopiroxênio menos afetados pelo hidrotermalismo por possuírem maiores concentrações de $\mathrm{Cr}_{2} \mathrm{O}_{3}$ e $\mathrm{TiO}_{2}$ dentre os demais cristais. Variações dos teores de $\mathrm{Cr}_{2} \mathrm{O}_{3}$ e $\mathrm{TiO}_{2}$ não demonstram nenhuma correlação com teores de $\mathrm{CaO}$ (Fig. 7). 
Tabela 2 - Análises representativas de química de olivina

\begin{tabular}{|c|c|c|c|c|c|c|c|c|c|c|c|c|c|c|}
\hline $\begin{array}{l}\text { Rock } \\
\text { type }\end{array}$ & \multicolumn{7}{|c|}{ Peridotite } & \multicolumn{4}{|c|}{ Peridotite } & \multicolumn{3}{|c|}{ Dunite } \\
\hline $\begin{array}{c}\text { Analysis } \\
(\%)\end{array}$ & $\begin{array}{c}\text { FS-101 } \\
\text { III_CIII } \\
\_1\end{array}$ & $\begin{array}{c}\text { FS-101 } \\
\text { III_CIII } \\
\ldots 2\end{array}$ & $\begin{array}{c}\text { FS-101 } \\
\text { III_CIII } \\
\ldots 3\end{array}$ & $\begin{array}{c}\text { FS-101 } \\
\text { III_CIII } \\
\ldots 4\end{array}$ & $\begin{array}{l}\text { FS-101 } \\
\text { III_CIII } \\
\_5\end{array}$ & $\begin{array}{c}\text { FS-101 } \\
\text { III_CIII } \\
\text { 6 }\end{array}$ & $\begin{array}{c}\text { FS-101 } \\
\text { III_CII } \\
\text { I_7 }\end{array}$ & $\begin{array}{c}\text { FS-123 } \\
93.95 \\
\text { _CIV_16 }\end{array}$ & $\begin{array}{c}\text { FS-123 } \\
93.95 \\
\text { _CIV_18 }\end{array}$ & $\begin{array}{c}\text { FS-123 } \\
93.95 \\
\text { CIV_19 }\end{array}$ & $\begin{array}{c}\text { FS-123 } \\
93.95 \\
\text { CIV_20 }\end{array}$ & $\begin{array}{l}\text { AM11 } \\
\text { C2_26 }\end{array}$ & $\begin{array}{l}\text { AM11 } \\
\text { C3_46 }\end{array}$ & $\begin{array}{l}\text { AM11 } \\
\text { C3_47 }\end{array}$ \\
\hline $\mathrm{SiO}_{2}$ & 39.41 & 38.88 & 39.28 & 39.66 & 39.15 & 39.25 & 38.93 & 38.59 & 38.63 & 38.41 & 38.59 & 40.38 & 39.27 & 39.82 \\
\hline $\mathrm{TiO}_{2}$ & 0.23 & 0.00 & 0.05 & 0.00 & 0.09 & 0.03 & 0.00 & 0.00 & 0.00 & 0.08 & 0.00 & 0.00 & 0.00 & 0.17 \\
\hline $\mathrm{Al}_{2} \mathrm{O}_{3}$ & 0.00 & 0.00 & 0.04 & 0.00 & 0.00 & 0.00 & 0.03 & 0.00 & 0.01 & 0.02 & 0.01 & 0.00 & 0.00 & 0.02 \\
\hline $\mathrm{Cr}_{2} \mathrm{O}_{3}$ & 0.00 & 0.04 & 0.00 & 0.05 & 0.00 & 0.00 & 0.00 & 0.00 & 0.00 & 0.05 & 0.00 & 0.03 & 0.00 & 0.00 \\
\hline $\mathrm{FeO}$ & 13.79 & 13.48 & 13.79 & 13.28 & 13.78 & 14.05 & 13.97 & 15.40 & 15.60 & 15.75 & 15.44 & 12.46 & 13.22 & 12.44 \\
\hline $\mathrm{MnO}$ & 0.13 & 0.12 & 0.24 & 0.15 & 0.20 & 0.18 & 0.22 & 0.34 & 0.34 & 0.29 & 0.33 & 0.15 & 0.22 & 0.21 \\
\hline $\mathrm{MgO}$ & 46.01 & 46.39 & 46.02 & 46.46 & 45.78 & 45.04 & 45.67 & 44.08 & 44.33 & 44.05 & 44.56 & 47.15 & 48.01 & 47.45 \\
\hline $\mathrm{CaO}$ & 0.02 & 0.00 & 0.01 & 0.00 & 0.00 & 0.02 & 0.00 & 0.00 & 0.02 & 0.00 & 0.00 & 0.03 & 0.01 & 0.00 \\
\hline $\mathrm{NiO}$ & 0.30 & 0.27 & 0.27 & 0.31 & 0.27 & 0.26 & 0.31 & 0.31 & 0.31 & 0.29 & 0.28 & 0.35 & 0.26 & 0.42 \\
\hline $\mathrm{SrO}$ & 0.00 & 0.07 & 0.03 & 0.02 & 0.09 & 0.04 & 0.00 & 0.08 & 0.00 & 0.05 & 0.00 & 0.04 & 0.00 & 0.01 \\
\hline $\mathrm{ZnO}$ & 0.00 & 0.00 & 0.00 & 0.16 & 0.00 & 0.11 & 0.07 & 0.05 & 0.04 & 0.07 & 0.02 & 0.04 & 0.00 & 0.06 \\
\hline $\mathrm{H}_{2} \mathrm{O}$ & 0.00 & 0.73 & 0.20 & 0.00 & 0.49 & 0.94 & 0.76 & 1.10 & 0.70 & 0.90 & 0.62 & 0.00 & 0.00 & 0.00 \\
\hline Total & 100.00 & 100.00 & 100.00 & 100.18 & 100.00 & 100.00 & 100.00 & 100.00 & 100.00 & 100.00 & 100.00 & 100.62 & 100.99 & 100.61 \\
\hline \multicolumn{15}{|c|}{ Numbers of ions on basis of $4 \mathrm{O}$} \\
\hline $\mathrm{Si}$ & 0.98 & 0.97 & 0.98 & 0.99 & 0.98 & 0.99 & 0.98 & 0.98 & 0.98 & 0.98 & 0.98 & 1.00 & 0.96 & 0.98 \\
\hline $\mathrm{Ti}$ & 0.00 & 0.00 & 0.00 & 0.00 & 0.00 & 0.00 & 0.00 & 0.00 & 0.00 & 0.00 & 0.00 & 0.00 & 0.00 & 0.00 \\
\hline $\mathrm{Al}$ & 0.00 & 0.00 & 0.00 & 0.00 & 0.00 & 0.00 & 0.00 & 0.00 & 0.00 & 0.00 & 0.00 & 0.00 & 0.00 & 0.00 \\
\hline $\mathrm{Cr}$ & 0.00 & 0.00 & 0.00 & 0.00 & 0.00 & 0.00 & 0.00 & 0.00 & 0.00 & 0.00 & 0.00 & 0.00 & 0.00 & 0.00 \\
\hline $\mathrm{Fe}^{2+}$ & 0.29 & 0.28 & 0.29 & 0.28 & 0.29 & 0.30 & 0.29 & 0.33 & 0.33 & 0.34 & 0.33 & 0.26 & 0.27 & 0.26 \\
\hline $\mathrm{Mn}$ & 0.00 & 0.00 & 0.01 & 0.00 & 0.00 & 0.00 & 0.00 & 0.01 & 0.01 & 0.01 & 0.01 & 0.00 & 0.00 & 0.00 \\
\hline $\mathrm{Mg}$ & 1.71 & 1.73 & 1.72 & 1.72 & 1.71 & 1.70 & 1.71 & 1.67 & 1.68 & 1.67 & 1.68 & 1.73 & 1.76 & 1.74 \\
\hline $\mathrm{Ca}$ & 0.00 & 0.00 & 0.00 & 0.00 & 0.00 & 0.00 & 0.00 & 0.00 & 0.00 & 0.00 & 0.00 & 0.00 & 0.00 & 0.00 \\
\hline $\mathrm{Ni}$ & 0.01 & 0.01 & 0.01 & 0.01 & 0.01 & 0.01 & 0.01 & 0.01 & 0.01 & 0.01 & 0.01 & 0.01 & 0.01 & 0.01 \\
\hline $\mathrm{Sr}$ & 0.00 & 0.00 & 0.00 & 0.00 & 0.00 & 0.00 & 0.00 & 0.00 & 0.00 & 0.00 & 0.00 & 0.00 & 0.00 & 0.00 \\
\hline Cations & 3.00 & 3.00 & 3.00 & 3.00 & 3.00 & 3.00 & 3.00 & 3.00 & 3.00 & 3.00 & 3.00 & 3.00 & 3.00 & 3.00 \\
\hline Fo & 85.60 & 85.99 & 85.61 & 86.18 & 85.56 & 85.11 & 85.36 & 83.62 & 83.52 & 83.29 & 83.72 & 87.09 & 86.62 & 87.18 \\
\hline $\mathrm{Fa}$ & 14.40 & 14.01 & 14.39 & 13.82 & 14.44 & 14.89 & 14.64 & 16.38 & 16.48 & 16.71 & 16.28 & 12.91 & 13.38 & 12.82 \\
\hline $\mathrm{Ni}(\mathrm{ppm})$ & 2325.97 & 2153.09 & 2129.52 & 2443.84 & 2098.09 & 2011.65 & 2396.69 & 2435.98 & 2435.98 & 2302.39 & 2168.81 & 2750.30 & 2043.08 & 3331.79 \\
\hline
\end{tabular}

\subsection{Flogopita}

A fórmula estrutural dos tipos de flogopita que ocorrem na SSLMB foi calculada com base em onze oxigênios $(\mathrm{OH}, \mathrm{F}, \mathrm{Cl})$ (Tabela 4). As relações petrográficas associadas a análises de química mineral indicam a ocorrência de três populações de flogopita (Fig. $8)$.

A população I constitui de lamelas de flogopita sageníticas (núcleo e borda) que ocorrem nos peridotitos e srp-mt-vrm - flogopititos, sem orientação preferencial e associada à olivina e clinopiroxênio. Essa população é constituída das lamelas com menores concentrações de $\mathrm{FeO}\left(0,97 \mathrm{a}\right.$ 6,87\%), $\mathrm{Fe}_{2} \mathrm{O}_{3}\left(0,07\right.$ a 2,97\%), $\mathrm{TiO}_{2}(0,06$ a $1,23 \%)$ e $\mathrm{Al}_{2} \mathrm{O}_{3}(11,12$ a 13,42\%) e maiores concentrações de $\mathrm{MgO}(22,09$ a 27,27\%) em relação às outras populações. Associada ao clinopiroxenito e vrm-flogopitito ocorre flogopita da população II, com concentrações de $\mathrm{FeO}, \mathrm{Fe}_{2} \mathrm{O}_{3}, \mathrm{TiO}_{2}, \mathrm{Al}_{2} \mathrm{O}_{3}$ e $\mathrm{MgO}$ variando de 3,76 a $9,82 \%, 0$ a 2,83\%, 0,96 a $2,40 \%, 13,46$ a $15,50 \%$ e 18,25 a $23,02 \%$, respectivamente. As lamelas de flogopita dos hornblenditos ocorrem associadas à hornblenda, orientadas segundo um plano com direção preferencial. Estas lamelas 
possuem os maiores teores de $\mathrm{FeO}\left(10,19\right.$ a 14,36\%) e $\mathrm{Fe}_{2} \mathrm{O}_{3}(0,74$ a 3,37\%), representando a população III.

Tabela 3 - Dados representativos de clinopiroxênio. Abreviação mineral segundo Whitney e Evans (2010). *na = não analisado.

\begin{tabular}{|c|c|c|c|c|c|c|c|c|c|c|}
\hline Rock Type & \multicolumn{8}{|c|}{ Clinopyroxenite/Vrm-phlogopitite } & \multicolumn{2}{|c|}{ Wehrlite } \\
\hline Analysis & & & & FS17 & & FS123 & FS123 & FS15 & FS123 & FS123 \\
\hline & AlM1/B & Am21 & $\mathrm{AlM} 21$ & 28.65 & FS33A & 100.19 & 90.92 & 1III & 93.95 & 93.95 \\
\hline & & & & cpI_2 & & _CIII_9 & CI_2 & CIV_1 & CI_3 & CII_10 \\
\hline $\mathrm{SiO}_{2}$ & 52.76 & 53.59 & 53.08 & 54.79 & 53.48 & 54.87 & 54.28 & 54.21 & 53.32 & 53.58 \\
\hline $\mathrm{TiO}_{2}$ & 0.09 & 0.00 & 0.03 & 0.67 & 0.02 & 0.00 & 0.00 & 0.04 & 0.20 & 0.23 \\
\hline $\mathrm{Al}_{2} \mathrm{O}_{3}$ & 1.25 & 0.71 & 0.83 & 0.31 & 0.59 & 0.87 & 0.80 & 1.18 & 0.86 & 1.17 \\
\hline $\mathrm{Cr}_{2} \mathrm{O}_{3}$ & 0.00 & 0.09 & 0.00 & 0.33 & 0.09 & 0.01 & 0.02 & 0.19 & 0.18 & 0.17 \\
\hline $\mathrm{Fe}_{2} \mathrm{O}_{3}$ & 4.16 & 2.23 & 4.00 & 1.75 & 2.84 & 0.00 & 0.29 & 0.00 & 2.00 & 0.92 \\
\hline $\mathrm{FeO}$ & 1.03 & 1.12 & 0.00 & 1.74 & 0.52 & 4.71 & 3.29 & 4.74 & 2.43 & 3.79 \\
\hline $\mathrm{MnO}$ & 0.11 & 0.05 & 0.00 & 0.01 & 0.19 & 0.15 & 0.10 & 0.10 & 0.18 & 0.11 \\
\hline $\mathrm{MgO}$ & 15.42 & 17.27 & 16.47 & 16.59 & 16.98 & 18.35 & 16.39 & 14.33 & 17.92 & 18.05 \\
\hline $\mathrm{CaO}$ & 24.22 & 23.36 & 24.17 & 23.56 & 24.08 & 19.34 & 23.86 & 23.75 & 21.41 & 20.83 \\
\hline $\mathrm{Na}_{2} \mathrm{O}$ & 0.71 & 0.45 & 0.69 & 0.99 & 0.45 & 0.50 & 0.37 & 0.81 & 0.39 & 0.32 \\
\hline $\mathrm{ZnO}$ & 0.15 & 0.02 & 0.00 & na & 0.00 & 0.00 & 0.01 & 0.08 & 0.00 & 0.00 \\
\hline $\mathrm{NiO}$ & 0.07 & 0.09 & 0.04 & na & 0.03 & 0.00 & 0.03 & 0.02 & 0.15 & 0.04 \\
\hline Total & 99.97 & 98.97 & 99.32 & 100.74 & 99.28 & 98.80 & 99.44 & 99.44 & 99.04 & 99.19 \\
\hline \multicolumn{11}{|c|}{ number of ions on the base of 6 oxygens } \\
\hline $\mathrm{Si}$ & 1.94 & 1.97 & 1.95 & 1.98 & 1.96 & 2.01 & 1.99 & 2.00 & 1.96 & 1.96 \\
\hline $\mathrm{Al}^{\mathrm{IV}}$ & 0.05 & 0.03 & 0.04 & 0.01 & 0.03 & 0.00 & 0.01 & 0.00 & 0.04 & 0.04 \\
\hline $\mathrm{Al}^{\mathrm{VI}}$ & 0.00 & 0.00 & 0.00 & 0.00 & 0.00 & 0.04 & 0.03 & 0.05 & 0.00 & 0.02 \\
\hline $\mathrm{Fe}^{3+}$ & 0.11 & 0.06 & 0.11 & 0.05 & 0.08 & 0.00 & 0.01 & 0.00 & 0.06 & 0.03 \\
\hline $\mathrm{Cr}$ & 0.00 & 0.00 & 0.00 & 0.01 & 0.00 & 0.00 & 0.00 & 0.01 & 0.01 & 0.00 \\
\hline $\mathrm{Ti}$ & 0.00 & 0.00 & 0.00 & 0.02 & 0.00 & 0.00 & 0.00 & 0.00 & 0.01 & 0.01 \\
\hline $\mathrm{Mg}$ & 0.84 & 0.95 & 0.90 & 0.89 & 0.93 & 1.00 & 0.90 & 0.79 & 0.98 & 0.99 \\
\hline $\mathrm{Fe}^{2+}$ & 0.03 & 0.03 & 0.00 & 0.05 & 0.02 & 0.14 & 0.10 & 0.15 & 0.07 & 0.12 \\
\hline Mn & 0.00 & 0.00 & 0.00 & 0.00 & 0.01 & 0.00 & 0.00 & 0.00 & 0.01 & 0.00 \\
\hline $\mathrm{Ca}$ & 0.95 & 0.92 & 0.95 & 0.91 & 0.95 & 0.76 & 0.94 & 0.94 & 0.84 & 0.82 \\
\hline $\mathrm{Na}$ & 0.05 & 0.03 & 0.05 & 0.07 & 0.03 & 0.04 & 0.03 & 0.06 & 0.03 & 0.02 \\
\hline $\mathrm{Zn}$ & 0.00 & 0.00 & 0.00 & 0.00 & 0.00 & 0.00 & 0.00 & 0.00 & 0.00 & 0.00 \\
\hline $\mathrm{Ni}$ & 0.00 & 0.00 & 0.00 & 0.00 & 0.00 & 0.00 & 0.00 & 0.00 & 0.00 & 0.00 \\
\hline Cations & 4.00 & 4.00 & 4.00 & 4.00 & 4.00 & 4.00 & 4.00 & 4.00 & 4.00 & 4.00 \\
\hline Wo & 49.02 & 46.87 & 48.44 & 47.86 & 48.06 & 39.84 & 48.26 & 50.11 & 43.12 & 42.05 \\
\hline En & 43.44 & 48.23 & 45.94 & 46.89 & 47.14 & 52.59 & 46.13 & 42.09 & 50.22 & 50.69 \\
\hline Fs & 7.54 & 4.90 & 5.63 & 5.25 & 4.80 & 7.58 & 5.61 & 7.80 & 6.66 & 7.27 \\
\hline
\end{tabular}

\subsection{Anfibólios}

Antofilita, actinolita, tremolita e hornblenda são os quatro tipos de minerais do grupo do anfibólio na SSLMB, com análises representativas na Tabela 5. A fórmula estrutural foi calculada com base em vinte e três oxigênios, utilizando a tabela de classificação de anfibólios disponibilizada em Locock (2014).

Os teores de $\mathrm{CaO}$ separam os cristais de antofilita dos demais cristais de anfibólios. As concentações de $\mathrm{CaO}$ e $\mathrm{Al}_{2} \mathrm{O}_{3}$ nos cristais de antofilita variam de $0,25 \mathrm{a}$ $0,39 \%$ e 0,03 a $0,28 \%$, respectivamente. A variação dos teores $\mathrm{CaO}$ para actinolita, tremolita e hornblenda são muito próximas, variando de 11,95 a 12,70\%, 12,28 a $13,33 \%$ e 11,37 a 12,57\%, respectivamente, porém as concentrações de $\mathrm{Al}_{2} \mathrm{O}_{3}$ são discriminantes e permitem a distinção entre os minerais, variando de 0,55 a 6,71\%, 0,17 a 3,11\%, e 5,23 a 11,45\%. Endenita, magnésio-hastingsita, magnésio-ferri-hornblenda e 
pargasita são os membros do grupo da hornblenda que ocorrem na SSLMB. A classificação dos anfibólios segue as recomendações da Associação Internacional de Mineralogia descrita em detalhe por Hawthorne et al., (2012) e Oberti et al., (2012).

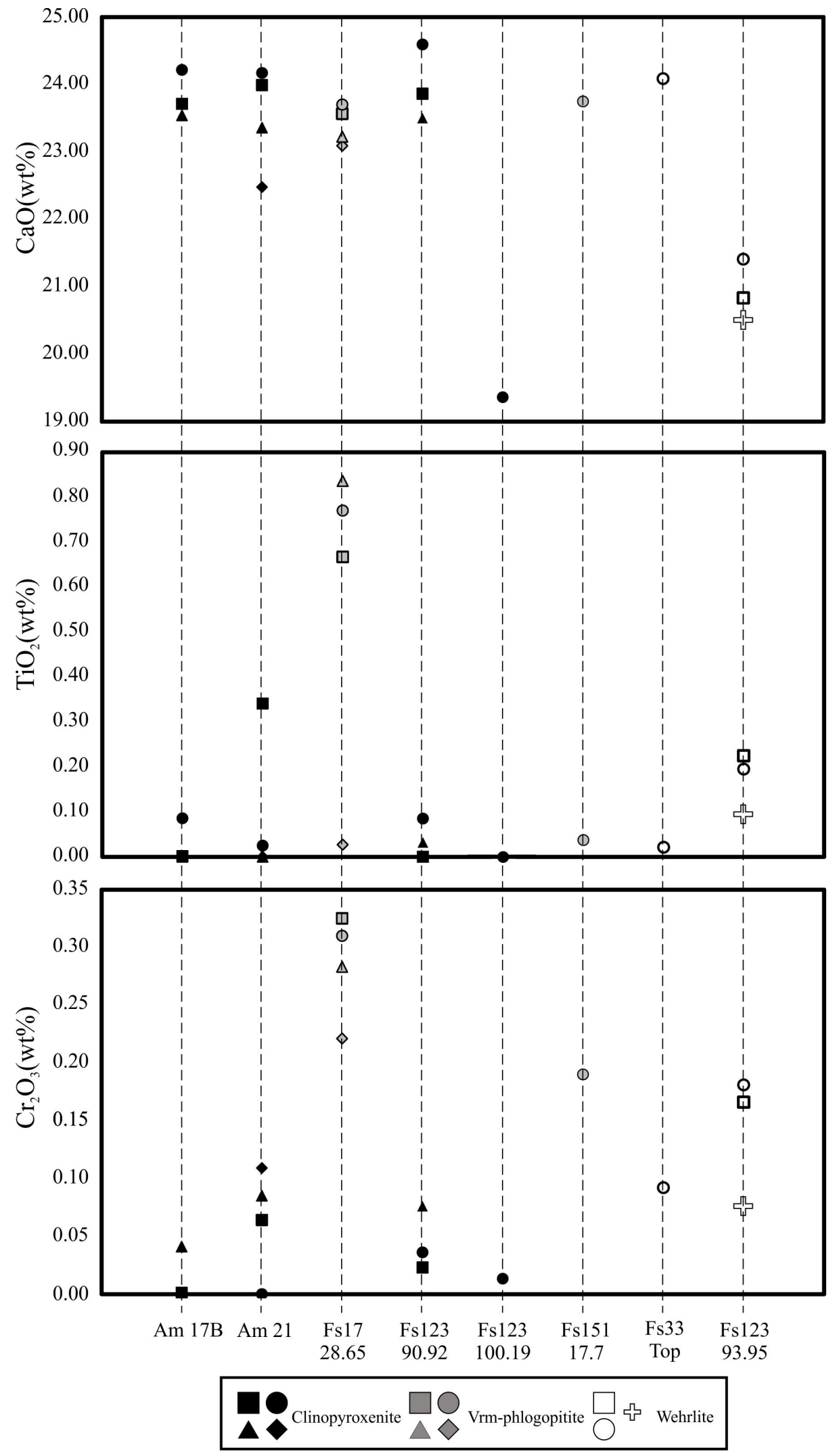

Figura 7 - Conteúdo de $\mathrm{CaO}, \mathrm{TiO}_{2}$ e $\mathrm{Cr}_{2} \mathrm{O}_{3}$ em diopsídio nas rochas ultramáficas da SSLMB. 
Tabela 4 - Dados representativos de química de flogopita. Abreviação mineral segundo Whitney e Evans (2010).

\begin{tabular}{|c|c|c|c|c|c|c|c|c|c|c|}
\hline \multirow{2}{*}{ Rock type } & \multicolumn{2}{|c|}{ Hornblendite } & \multirow{2}{*}{\multicolumn{5}{|c|}{ Vrm-phlogopitite/Clinopiroxenite }} & \multirow{2}{*}{\multicolumn{3}{|c|}{ Srp-mt-vrm-phlogopitite/Wehrlite }} \\
\hline & Type I & Type II & & & & & & & & \\
\hline $\begin{array}{c}\text { Analysis } \\
\text { (wt } \%)\end{array}$ & $\begin{array}{l}\mathrm{AM} 20 \\
\mathrm{C5} 888\end{array}$ & $\begin{array}{c}\text { FS-33C } \\
\text { CI_3 }\end{array}$ & $\begin{array}{l}\text { AM17B } \\
\text { C2_58 }\end{array}$ & $\begin{array}{l}\text { AM31 } \\
\text { C1_42 }\end{array}$ & $\begin{array}{l}\text { FS-151III } \\
\text { CII_14 }\end{array}$ & $\begin{array}{c}\text { FS- } \\
\text { 123IV } \\
\text { CII_7 }\end{array}$ & $\begin{array}{l}\text { FS-123-I } \\
\text { CI_22 }\end{array}$ & $\begin{array}{l}\text { Fs100 } \\
\text { CII_8 }\end{array}$ & $\begin{array}{c}\text { FS-101-III } \\
\text { CIV_3 }\end{array}$ & $\begin{array}{c}\text { FS-123-III } \\
\text { CIV_21 }\end{array}$ \\
\hline $\mathrm{SiO}_{2}$ & 36.61 & 37.49 & 38.76 & 39.79 & 39.57 & 40.22 & 39.81 & 42.61 & 39.87 & 41.00 \\
\hline $\mathrm{TiO}_{2}$ & 1.63 & 1.55 & 1.25 & 1.55 & 2.03 & 1.87 & 2.09 & 0.06 & 0.31 & 0.79 \\
\hline $\mathrm{Al}_{2} \mathrm{O}_{3}$ & 16.03 & 14.30 & 16.55 & 14.50 & 15.11 & 13.46 & 14.06 & 11.70 & 12.41 & 13.24 \\
\hline $\mathrm{Cr}_{2} \mathrm{O}_{3}$ & 0.02 & 0.06 & 0.20 & 0.36 & 0.33 & 0.09 & 0.31 & 0.16 & 0.18 & 0.05 \\
\hline $\mathrm{Fe}_{2} \mathrm{O}_{3}$ & 1.37 & 2.33 & 0.21 & 1.11 & 0.00 & 0.95 & 2.18 & 1.29 & 2.05 & 2.26 \\
\hline $\mathrm{FeO}$ & 14.36 & 11.75 & 8.28 & 5.23 & 9.53 & 6.55 & 6.16 & 2.08 & 0.97 & 2.68 \\
\hline $\mathrm{MnO}$ & 0.26 & 0.09 & 0.06 & 0.02 & 0.11 & 0.00 & 0.09 & 0.07 & 0.03 & 0.03 \\
\hline $\mathrm{MgO}$ & 14.82 & 17.36 & 19.48 & 22.05 & 18.45 & 21.28 & 20.96 & 27.27 & 27.27 & 25.24 \\
\hline $\mathrm{CaO}$ & 0.05 & 0.00 & 0.05 & 0.03 & 0.07 & 0.02 & 0.02 & 0.03 & 0.09 & 0.02 \\
\hline $\mathrm{Na}_{2} \mathrm{O}$ & 0.12 & 0.14 & 0.07 & 0.29 & 0.12 & 0.21 & 0.11 & 0.08 & 0.21 & 0.50 \\
\hline $\mathrm{K}_{2} \mathrm{O}$ & 9.58 & 9.73 & 9.78 & 10.02 & 10.34 & 9.95 & 9.68 & 9.60 & 9.49 & 9.53 \\
\hline $\mathrm{BaO}$ & 0.64 & 0.62 & 0.33 & 0.10 & 0.15 & 0.38 & 0.39 & 0.29 & 0.31 & 0.27 \\
\hline $\mathrm{ZnO}$ & 0.11 & 0.04 & 0.00 & 0.00 & 0.00 & 0.06 & 0.06 & 0.02 & 0.10 & 0.00 \\
\hline $\mathrm{NiO}$ & 0.06 & 0.04 & 0.16 & 0.23 & 0.04 & 0.18 & 0.00 & 0.13 & 0.15 & 0.07 \\
\hline $\mathrm{F}$ & 0.22 & 0.04 & 0.59 & 0.76 & 0.39 & 0.49 & 0.24 & 0.35 & 0.17 & 0.32 \\
\hline $\mathrm{Cl}$ & 0.01 & 0.01 & 0.02 & 0.01 & 0.01 & 0.02 & 0.05 & 0.02 & 0.00 & 0.03 \\
\hline $\mathrm{H}_{2} \mathrm{O}$ & 3.86 & 3.98 & 3.82 & 3.78 & 3.93 & 3.88 & 4.02 & 4.15 & 4.10 & 4.05 \\
\hline Subtotal & 99.75 & 99.51 & 99.61 & 99.83 & 100.17 & 99.61 & 100.22 & 99.92 & 97.70 & 100.06 \\
\hline $\mathrm{O}=\mathrm{F}, \mathrm{Cl}$ & 0.23 & 0.05 & 0.61 & 0.77 & 0.40 & 0.51 & 0.28 & 0.38 & 0.17 & 0.35 \\
\hline Total & 99.52 & 99.47 & 98.99 & 99.06 & 99.77 & 99.10 & 99.93 & 99.54 & 97.53 & 99.72 \\
\hline \multicolumn{11}{|c|}{ Number of ions on the base of 11 oxygens } \\
\hline $\mathrm{Si}$ & 2.76 & 2.81 & 2.81 & 2.86 & 2.87 & 2.91 & 2.87 & 2.99 & 2.86 & 2.91 \\
\hline $\mathrm{Al}^{\text {IV }}$ & 1.24 & 1.19 & 1.19 & 1.14 & 1.13 & 1.09 & 1.13 & 0.97 & 1.05 & 1.09 \\
\hline $\mathrm{Al}^{\mathrm{VI}}$ & 0.18 & 0.07 & 0.23 & 0.09 & 0.16 & 0.06 & 0.06 & 0.00 & 0.00 & 0.02 \\
\hline $\mathrm{Ti}$ & 0.09 & 0.09 & 0.07 & 0.08 & 0.11 & 0.10 & 0.11 & 0.00 & 0.02 & 0.04 \\
\hline $\mathrm{Fe}^{3+}$ & 0.08 & 0.13 & 0.01 & 0.06 & 0.00 & 0.05 & 0.12 & 0.07 & 0.11 & 0.12 \\
\hline $\mathrm{Fe}^{2+}$ & 0.90 & 0.74 & 0.50 & 0.31 & 0.58 & 0.40 & 0.37 & 0.12 & 0.06 & 0.16 \\
\hline $\mathrm{Mn}$ & 0.02 & 0.01 & 0.00 & 0.00 & 0.01 & 0.00 & 0.01 & 0.00 & 0.00 & 0.00 \\
\hline $\mathrm{Mg}$ & 1.66 & 1.94 & 2.11 & 2.36 & 1.99 & 2.30 & 2.25 & 2.85 & 2.92 & 2.67 \\
\hline $\mathrm{Cr}$ & 0.00 & 0.00 & 0.01 & 0.02 & 0.02 & 0.01 & 0.02 & 0.01 & 0.01 & 0.00 \\
\hline $\mathrm{Ni}$ & 0.00 & 0.00 & 0.01 & 0.01 & 0.00 & 0.01 & 0.00 & 0.01 & 0.01 & 0.00 \\
\hline $\mathrm{Ca}$ & 0.00 & 0.00 & 0.00 & 0.00 & 0.01 & 0.00 & 0.00 & 0.00 & 0.01 & 0.00 \\
\hline $\mathrm{Na}$ & 0.02 & 0.02 & 0.01 & 0.04 & 0.02 & 0.03 & 0.02 & 0.01 & 0.03 & 0.07 \\
\hline $\mathrm{K}$ & 0.92 & 0.93 & 0.90 & 0.92 & 0.96 & 0.92 & 0.89 & 0.86 & 0.87 & 0.86 \\
\hline $\mathrm{Ba}$ & 0.02 & 0.02 & 0.01 & 0.00 & 0.00 & 0.01 & 0.01 & 0.01 & 0.01 & 0.01 \\
\hline $\mathrm{F}$ & 0.05 & 0.01 & 0.14 & 0.17 & 0.09 & 0.11 & 0.05 & 0.08 & 0.04 & 0.07 \\
\hline $\mathrm{Cl}$ & 0.00 & 0.00 & 0.00 & 0.00 & 0.00 & 0.00 & 0.01 & 0.00 & 0.00 & 0.00 \\
\hline $\mathrm{OH}$ & 1.95 & 1.99 & 1.86 & 1.83 & 1.91 & 1.89 & 1.94 & 1.92 & 1.96 & 1.93 \\
\hline Cations & 7.90 & 7.94 & 7.86 & 7.91 & 7.85 & 7.88 & 7.86 & 7.91 & 7.95 & 7.96 \\
\hline $\mathrm{Al}_{\text {total }}$ & 1.42 & 1.26 & 1.41 & 1.23 & 1.29 & 1.15 & 1.19 & 0.97 & 1.05 & 1.11 \\
\hline $\mathrm{Mg \#}$ & 0.63 & 0.69 & 0.80 & 0.86 & 0.78 & 0.84 & 0.82 & 0.94 & 0.95 & 0.91 \\
\hline
\end{tabular}

Os anfibólios associados ao wehrlito e srp-mt-vrm flogopitito possuem os maiores valores para razão $\mathrm{Mg} /(\mathrm{Mg}+\mathrm{Fe})$ com média de 0,93 , comparado as razões dos anfibólios dos clinopiroxenito/vrm-flogopitito $(0,84)$ e os hornblenditos $(0,65)$. Uma correlação positiva entre $\mathrm{Na}_{2} \mathrm{O}$ e $\mathrm{Al}_{2} \mathrm{O}_{3}$ resulta da substituição endenítica de $\mathrm{Na}$ por $\mathrm{Al}^{\mathrm{IV}}$ e concentrações mais altas de $\mathrm{Na}_{2} \mathrm{O}$ ocorrem nos hornblenditos em relação às rochas ígneas encaixantes e derivados hidrotermais (Fig. 9). Os horblenditos também possuem maiores concentrações de $\mathrm{K}_{2} \mathrm{O}, \mathrm{Fe}^{2+}, \mathrm{TiO}_{2}$ em relação às demais rochas. Para $\mathrm{o}$ diagrama $\mathrm{K}_{2} \mathrm{O}$ versus $\mathrm{TiO}_{2}$ e $\mathrm{Fe}^{2+}$ (Fig. 10), a antofilita não foi considerada por apresentar concentrações muito baixas de $\mathrm{K}_{2} \mathrm{O}$. 

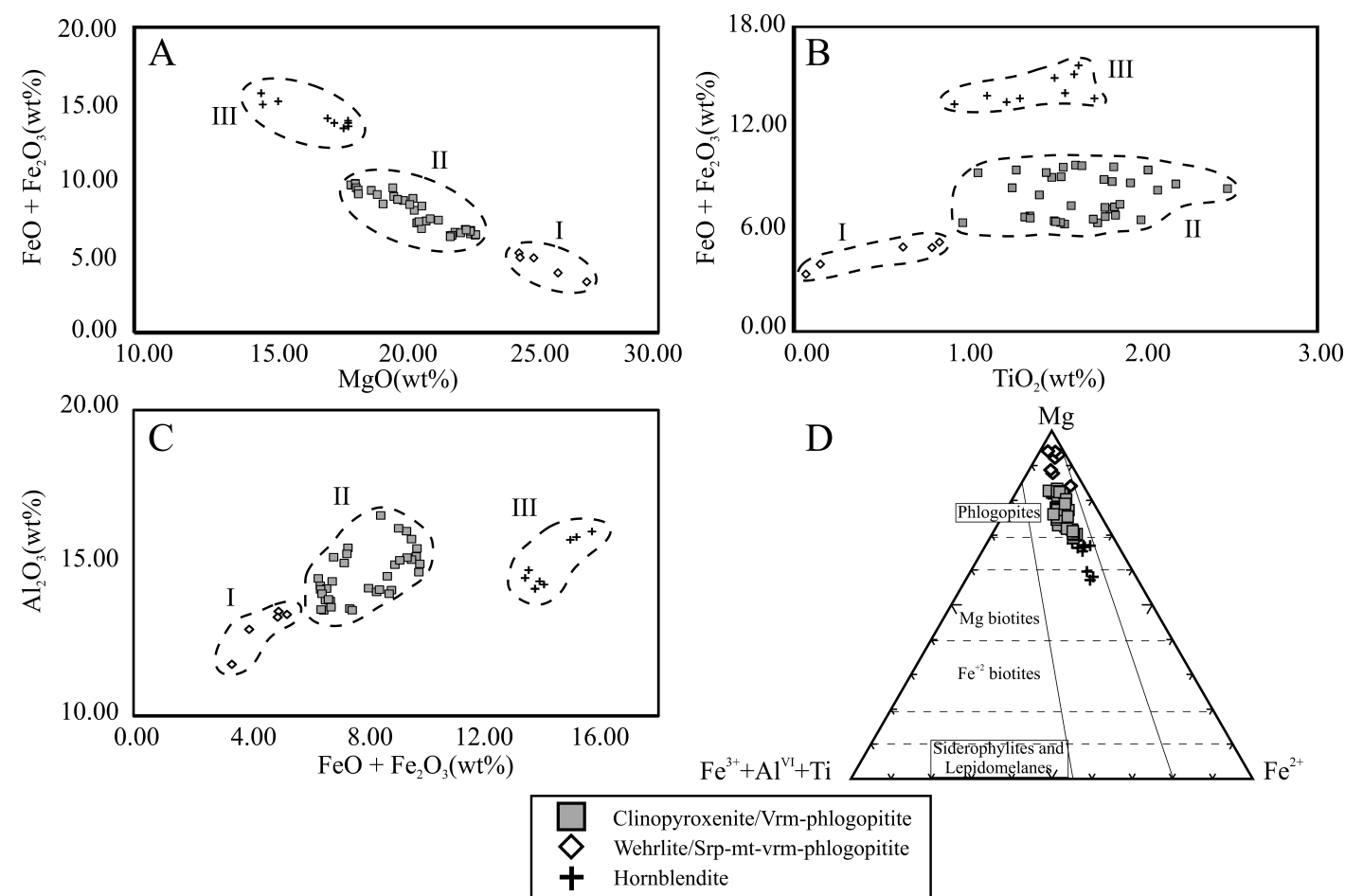

Figura 8 - A) e B) Teores de $\mathrm{FeO}+\mathrm{Fe}_{2} \mathrm{O}_{3}$ em função de $\mathrm{MgO}$ e $\mathrm{TiO}_{2}$ e C) $\mathrm{Al}_{2} \mathrm{O}_{3}$ em em função de $\mathrm{FeO}+\mathrm{Fe}_{2} \mathrm{O}_{3}$ das lamelas de flogopita. D) Relação de $\mathrm{Fe}, \mathrm{Al}^{\mathrm{VI}}$, Ti e Mg das lamelas de flogopita (modificado de Foster, 1960).

Concentrações significantes de flúor ocorrem apenas em hornblenda dos hornblenditos e antofilita pertencentes ao halo de alteração gerado a partir da intrusão de pegmatitos quartzo-feldspáticos. Os teores de flúor nesses cristais variam de 0,03 e $0,27 \%$, enquanto que nas demais rochas não apresentam teores detectáveis. A concentração de cloro nos anfibólio é irrelevante $(<0,03 \%)$.

\subsection{Titanita}

Os grãos de titanita possuem concentrações médias de $\mathrm{CaO}, \mathrm{TiO}_{2}$ e $\mathrm{SiO}_{2}$ de $28,08 \%, 38,67 \%$ e 29,84\%, com demais concentrações representativas de óxidos e átomos por fórmula unitária na Tabela 6. A fórmula da titanita foi calculada com base em cinco oxigênios. A proporção de $\mathrm{OH}$ foi calculada como $\mathrm{OH}=\left(\mathrm{Al}+\mathrm{Cr}+\mathrm{Fe}^{3+}\right)-\mathrm{F}$ Higgins e Ribbe (1976).

Três populações distintas de titanita foram identificadas (Fig. 11). As populações I e II ocorrem associadas à clinopiroxenito e vrm-flogopitito, porém a população I é constituída por aglomerados de grãos finos inclusos em lamelas de flogopita II, com concentrações de $\mathrm{Cr}_{2} \mathrm{O}_{3}$ entre 0,37 e $0,63 \%, \mathrm{Al}_{2} \mathrm{O}_{3}$ entre 0,28 e $0,92 \%$ e $\mathrm{Fe}_{2} \mathrm{O}_{3}$ entre 0,30 e $0,75 \%$. A população de titanita II é composta por cristais individuais com valores de $\mathrm{Cr}_{2} \mathrm{O}_{3}$ entre 0,17 e $0,24 \%$, de $\mathrm{Al}_{2} \mathrm{O}_{3}$ entre 1,02 e $1,43 \%$ e de $\mathrm{Fe}_{2} \mathrm{O}_{3}$ entre 0,17 e $0,24 \%$. A população III compreende grãos finos a médios de titanita, 
subédricos e intersticiais, associados à hornblenda, com concentrações de $\mathrm{Cr}_{2} \mathrm{O}_{3}, \mathrm{Al}_{2} \mathrm{O}_{3}$ e $\mathrm{Fe}_{2} \mathrm{O}_{3}$ variando de 0,00 a $0,04 \%, 0,89$ a $1,92 \%$ e 0,49 a $1,07 \%$, respectivamente.

Segundo Higgins e Ribbe (1976), o principal mecanismo para entrada de íon férrico, de alumínio e cromo em titanitas naturais seria segundo a equação de substituição:

$$
\left(\mathrm{Fe}^{3+}+\mathrm{Al}+\mathrm{Cr}^{3+}\right)+\left(\mathrm{OH}, \mathrm{F}^{-}\right) \Leftrightarrow \mathrm{Ti}^{4+}+\mathrm{O}^{2-}
$$

Esta equação descreve a acomodação de $\mathrm{Al}$ nas titanitas dos hornblenditos e de $\mathrm{Al}$ e $\mathrm{Cr}$ para as titanitas do clinopiroxenito e vrm-flogopitito em função da variação do $\mathrm{OH}$, uma vez que as análises de microssonda eletrônica não acusaram teores de flúor.

Tabela 5 - Análises representativas dos anfibólios da SSLMB. Abreviação Mineral segundo Whitney e Evans (2010). $*_{\text {na }}=$ não analisado.

\begin{tabular}{|c|c|c|c|c|c|c|c|c|c|c|}
\hline \multirow{2}{*}{$\begin{array}{l}\text { Rock type } \\
\text { Analysis } \\
\text { wt }(\%)\end{array}$} & \multicolumn{2}{|c|}{ Ath Vein } & \multicolumn{2}{|c|}{ Hornblendite } & \multicolumn{3}{|c|}{ Vrm-phlogopitite } & \multicolumn{3}{|c|}{ Srp-mt-vrm-phlogopitite/Wehrlite } \\
\hline & $\begin{array}{c}\text { AM13 } \\
\text { C1_1 }\end{array}$ & $\begin{array}{c}\text { AM17A } \\
\text { C3_40 }\end{array}$ & $\begin{array}{c}\text { AM20 } \\
\text { C2_117 }\end{array}$ & $\begin{array}{l}\text { FS33C } \\
\text { cpII_13 }\end{array}$ & $\begin{array}{c}\text { FS-123-I } \\
\text { CIV_5 }\end{array}$ & $\begin{array}{c}\text { FS- } \\
\text { 151III } \\
\text { CIII_7 }\end{array}$ & $\begin{array}{c}\text { FS17 } \\
\text { cpIV_14 }\end{array}$ & $\begin{array}{l}\text { Fs33A } \\
\text { CIII_1 }\end{array}$ & $\begin{array}{l}\text { AM17D } \\
\text { C3_64 }\end{array}$ & $\begin{array}{l}\text { FS-101- } \\
\text { III_CII_2 }\end{array}$ \\
\hline Species & Ath & Ath & $\mathrm{Hbl}$ & $\mathrm{Hbl}$ & Act & Act & $\mathrm{Tr}$ & $\operatorname{Tr}$ & $\operatorname{Tr}$ & $\operatorname{Tr}$ \\
\hline $\mathrm{SiO}_{2}$ & 56.60 & 55.67 & 43.77 & 47.08 & 54.75 & 55.47 & 55.09 & 54.86 & 56.28 & 56.24 \\
\hline $\mathrm{TiO}_{2}$ & 0.16 & 0.14 & 0.96 & 0.61 & 0.00 & 0.16 & 0.12 & 0.26 & 0.03 & 0.24 \\
\hline $\mathrm{Al}_{2} \mathrm{O}_{3}$ & 0.04 & 0.04 & 10.53 & 8.61 & 2.34 & 2.61 & 3.11 & 2.27 & 0.32 & 1.59 \\
\hline $\mathrm{Fe}_{2} \mathrm{O}_{3}$ & 2.70 & 4.33 & 6.60 & 0.00 & 2.66 & 0.00 & 2.29 & 4.95 & 3.43 & 1.30 \\
\hline $\mathrm{FeO}$ & 8.76 & 7.84 & 8.13 & 11.94 & 2.72 & 5.83 & 2.35 & 0.00 & 0.00 & 1.06 \\
\hline $\mathrm{MnO}$ & 0.14 & 0.53 & 0.11 & 0.32 & 0.03 & 0.15 & 0.00 & 0.22 & 0.18 & 0.12 \\
\hline $\mathrm{MgO}$ & 27.82 & 27.57 & 13.09 & 15.09 & 20.93 & 19.86 & 21.92 & 21.65 & 23.71 & 23.71 \\
\hline $\mathrm{CaO}$ & 0.38 & 0.33 & 11.55 & 11.86 & 12.39 & 12.58 & 12.28 & 12.70 & 12.37 & 12.72 \\
\hline $\mathrm{Na}_{2} \mathrm{O}$ & 0.06 & 0.03 & 1.73 & 2.01 & 0.79 & 0.64 & 1.31 & 0.73 & 0.21 & 0.58 \\
\hline $\mathrm{K}_{2} \mathrm{O}$ & 0.03 & 0.01 & 1.16 & 1.01 & 0.26 & 0.24 & 0.28 & 0.27 & 0.05 & 0.17 \\
\hline $\mathrm{ZnO}$ & 0.00 & 0.03 & 0.06 & na & 0.05 & 0.00 & na & 0.00 & 0.03 & 0.00 \\
\hline $\mathrm{Cr}_{2} \mathrm{O}_{3}$ & 0.00 & 0.04 & 0.02 & 0.16 & 0.12 & 0.14 & 0.55 & 0.30 & 0.02 & 0.01 \\
\hline $\mathrm{NiO}$ & 0.08 & 0.11 & 0.05 & 0.04 & 0.05 & 0.04 & 0.03 & 0.08 & 0.01 & 0.08 \\
\hline $\mathrm{SrO}$ & 0.00 & 0.02 & 0.00 & na & 0.00 & 0.03 & na & 0.00 & 0.00 & 0.00 \\
\hline $\mathrm{P}_{2} \mathrm{O}_{5}$ & 0.04 & 0.00 & 0.00 & 0.02 & 0.00 & 0.00 & 0.03 & 0.04 & 0.01 & 0.00 \\
\hline $\mathrm{H}_{2} \mathrm{O}$ & 2.14 & 2.15 & 1.93 & 1.96 & 2.15 & 2.15 & 2.14 & 2.12 & 2.1 & 2.18 \\
\hline $\mathrm{F}$ & 0.11 & 0.07 & 0.05 & 0.00 & 0.00 & 0.00 & 0.04 & 0.09 & 0.00 & 0.00 \\
\hline $\mathrm{Cl}$ & 0.00 & 0.00 & 0.01 & 0.01 & 0.05 & 0.02 & 0.01 & 0.03 & 0.00 & 0.03 \\
\hline $\mathrm{O}=\mathrm{F}, \mathrm{Cl}$ & -0.05 & -0.03 & -0.10 & 0.00 & -0.01 & 0.00 & -0.02 & -0.05 & -0.08 & -0.01 \\
\hline Total & 99.00 & 98.87 & 99.63 & 100.78 & 99.16 & 99.75 & 99.17 & 100.25 & 98.70 & 99.99 \\
\hline \multicolumn{11}{|c|}{ number of ions on the base of 23 oxygens } \\
\hline $\mathrm{Si}$ & 7.84 & 7.75 & 6.44 & 6.83 & 7.66 & 7.75 & 7.52 & 7.56 & 7.79 & 7.71 \\
\hline $\mathrm{P}$ & 0.01 & 0.00 & 0.00 & 0.00 & 0.00 & 0.00 & 0.00 & 0.01 & 0.00 & 0.00 \\
\hline $\mathrm{Al}^{\mathrm{IV}}$ & 0.01 & 0.01 & 1.56 & 1.17 & 0.34 & 0.43 & 0.48 & 0.37 & 0.05 & 0.26 \\
\hline $\mathrm{Al}^{\mathrm{VI}}$ & 0.00 & 0.00 & 0.26 & 0.30 & 0.04 & 0.43 & 0.03 & 0.00 & 0.00 & 0.00 \\
\hline $\mathrm{Ti}$ & 0.02 & 0.02 & 0.11 & 0.07 & 0.00 & 0.02 & 0.01 & 0.03 & 0.00 & 0.03 \\
\hline $\mathrm{Fe}^{3+}$ & 0.28 & 0.45 & 0.73 & 0.00 & 0.28 & 0.00 & 0.24 & 0.51 & 0.36 & 0.13 \\
\hline $\mathrm{Fe}^{2+}$ & 1.02 & 0.91 & 1.00 & 1.45 & 0.32 & 0.68 & 0.27 & 0.00 & 0.00 & 0.12 \\
\hline $\mathrm{Mn}^{3+}$ & 0.00 & 0.00 & 0.00 & 0.00 & 0.00 & 0.00 & 0.00 & 0.03 & 0.02 & 0.00 \\
\hline $\mathrm{Mn}^{2+}$ & 0.03 & 0.06 & 0.01 & 0.00 & 0.00 & 0.02 & 0.00 & 0.00 & 0.00 & 0.01 \\
\hline $\mathrm{Mg}$ & 5.74 & 5.72 & 2.87 & 3.26 & 4.36 & 4.14 & 4.46 & 4.45 & 4.89 & 4.84 \\
\hline $\mathrm{Cr}$ & 0.00 & 0.00 & 0.00 & 0.02 & 0.00 & 0.00 & 0.06 & 0.00 & 0.00 & 0.00 \\
\hline $\mathrm{Ni}$ & 0.01 & 0.01 & 0.01 & 0.00 & 0.01 & 0.01 & 0.00 & 0.01 & 0.00 & 0.01 \\
\hline $\mathrm{Zn}$ & 0.00 & 0.00 & 0.01 & na & 0.01 & 0.00 & 0.00 & 0.00 & 0.00 & 0.00 \\
\hline $\mathrm{Ca}$ & 0.06 & 0.05 & 1.82 & 1.84 & 1.86 & 1.88 & 1.80 & 1.87 & 1.83 & 1.87 \\
\hline $\mathrm{Na}$ & 0.02 & 0.01 & 0.49 & 0.57 & 0.21 & 0.17 & 0.35 & 0.20 & 0.06 & 0.16 \\
\hline $\mathrm{Sr}$ & 0.00 & 0.00 & 0.00 & na & 0.00 & 0.00 & 0.00 & 0.00 & 0.00 & 0.00 \\
\hline $\mathrm{K}$ & 0.00 & 0.00 & 0.22 & 0.19 & 0.05 & 0.04 & 0.05 & 0.05 & 0.01 & 0.03 \\
\hline $\mathrm{Cl}$ & 0.00 & 0.00 & 0.00 & 0.00 & 0.01 & 0.00 & 0.00 & 0.01 & 0.00 & 0.01 \\
\hline $\mathrm{F}$ & 0.05 & 0.03 & 0.02 & 0.00 & 0.00 & 0.00 & 0.02 & 0.04 & 0.00 & 0.00 \\
\hline $\mathrm{OH}$ & 1.95 & 1.97 & 1.98 & 2.00 & 1.99 & 2.00 & 1.98 & 1.95 & 2.00 & 1.99 \\
\hline Cations & 15.02 & 15.01 & 15.53 & 15.72 & 15.09 & 15.51 & 15.26 & 15.07 & 15.02 & 15.16 \\
\hline $\mathrm{Mg} \#$ & 0.82 & 0.81 & 0.62 & 0.69 & 0.88 & 0.86 & 0.90 & 0.90 & 0.93 & 0.95 \\
\hline
\end{tabular}




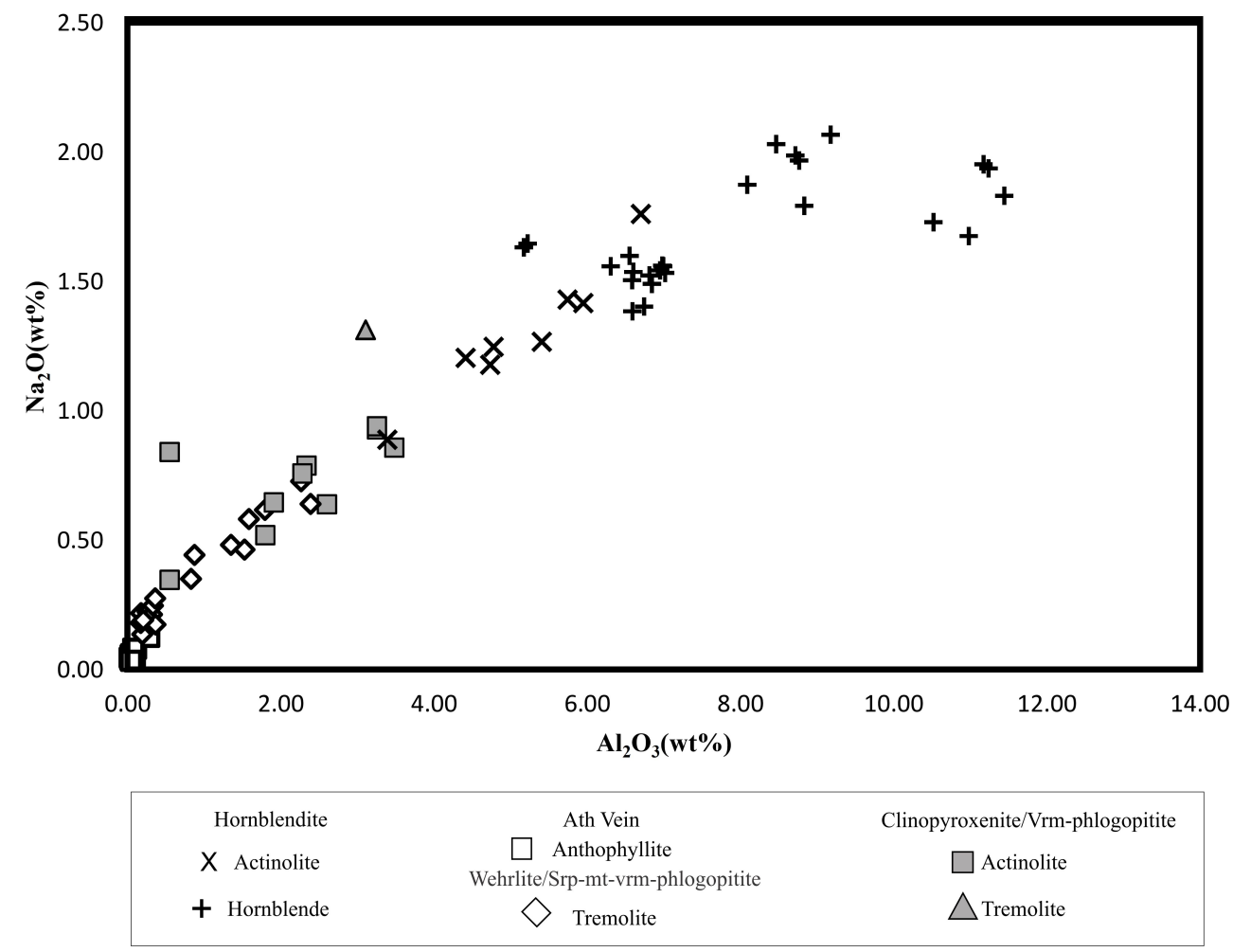

Figura 9 - Diagramas $\mathrm{Na}_{2} \mathrm{O}$ (wt \%) por $\mathrm{Al}_{2} \mathrm{O}_{3}$ (wt \%) dos anfibólios pertencentes aos corpos ultramáficos da SSLMB.

\subsection{Hidroflogopita e vermiculita}

Vermiculita é um filossilicato trioctaédrico com fórmula química estrutural $(\mathrm{Mg}, \mathrm{Ca})_{0,6-0,9}\left(\mathrm{Mg}, \mathrm{Fe}^{3+}, \mathrm{Al}\right)_{6,0}\left[(\mathrm{Si}, \mathrm{Al})_{8} \mathrm{O}_{20}\right](\mathrm{OH})_{4} \cdot \mathrm{nH}_{2} \mathrm{O}$ (Deer et al., 1992), semelhante à fórmula da flogopita, porém sem potássio e íon ferroso. Na SSLMB, a vermiculita é formada a partir das lamelas de flogopita, em um processo de transformação gradual, envolvendo a oxidação do íon ferroso, retirada do potássio e aumento das concentrações de magnésio e água na estrutura do mineral (Hindman, 1992). Tal processo é ilustrado pelas reações 1, 2 e 3 de biotita para vermiculita a seguir (Hindman, 1992):

$\mathrm{K}_{2}\left(\mathrm{Mg}_{4}, \mathrm{Fe}^{2+}{ }_{2}\right)\left[\mathrm{Si}_{6} \mathrm{Al}_{2} \mathrm{O}_{20}\right](\mathrm{OH})_{4}+\mathrm{Fe}^{3+} \rightarrow \mathrm{K}_{2}\left(\mathrm{Mg}_{4} \mathrm{Fe}^{+2} \mathrm{Fe}^{3+}\right)\left[\mathrm{Si}_{6} \mathrm{Al}_{2} \mathrm{O}_{20}\right](\mathrm{OH})_{4}+\mathrm{Fe}^{+2}$

Como o processo de formação de flogopita dos grupos I e II para vermiculita é gradual, ocorrem lamelas com concentrações de potássio e íon ferroso inferiores a flogopita, porém com concentrações de água e magnésio superiores. Essas lamelas são produto da hidratação da flogopita, com lixiviação de potássio e ocorrem interestratificadas a lamelas de vermiculita ou na borda das lamelas de flogopita (Figs. 
5C, 6B e 6C) (hidroflogopita). Nas equações de Hindman (1992) a fórmula química dessas lamelas varia do produto da reação 1 ao reagente da reação 3.
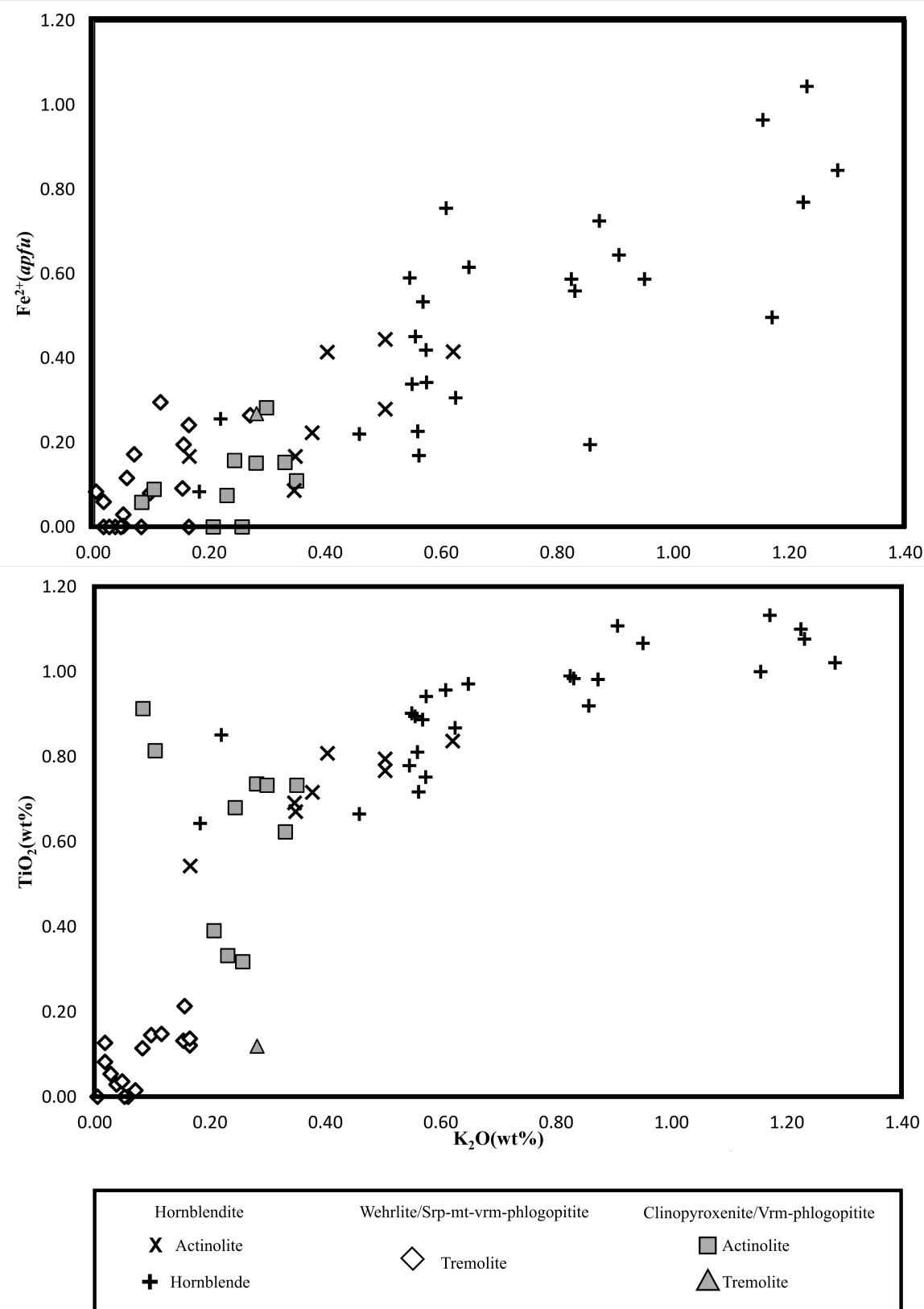

Figura 10 - Relação das concentrações de $\mathrm{Fe}^{2+}(\mathrm{apfu})$ e $\mathrm{TiO}_{2}(\mathrm{wt} \%)$ por $\mathrm{K}_{2} \mathrm{O}$ (wt $\%$ ) dos hornblenditos, wehrlitos, srpmt-vrm-flogopititos, clinopiroxenitos e vrm-flogopititos.

A fórmula estrutural foi calculada com base em onze oxigênios e concentração de $\mathrm{OH}$ obtido por $\mathrm{OH}=2-\mathrm{F}-\mathrm{Cl}$. A água na estrutura foi obtida a partir da razão entre o número de oxidrila e multiplicação entre o peso molecular da água e a soma do número de oxigênios para cada molécula.

Composições representativas de lamelas alteradas da flogopita e vermiculita são mostradas na Tabela 7. Diferentes populações são apontadas para as distintas rochas em que ocorrem, considerando seus teores de $\mathrm{Al}_{2} \mathrm{O}_{3}, \mathrm{MgO}, \mathrm{Fe}_{2} \mathrm{O}_{3}$ e $\mathrm{TiO}_{2}$ (Fig. 12). Associados a srp-mt-vrm-flogopititos, ocorrem as lamelas da população I formando um 
trend positivo, com concentrações de $\mathrm{MgO}, \mathrm{Fe}_{2} \mathrm{O}_{3}, \mathrm{TiO}_{2}, \mathrm{Al}_{2} \mathrm{O}_{3}, \mathrm{~K}_{2} \mathrm{O}$ e $\mathrm{H}_{2} \mathrm{O}$ total variando de 21,54 a $34,34 \%, 1,73$ a $9,67 \%, 0,03$ a $0,04 \%, 7,95$ a $13,18 \%, 0,0$ a 7,05\% e de 6,11 a $22,39 \%$, respectivamente.

Tabela 6 - Dados representativos de química de titanita. Abreviação mineral segundo Whitney e Evans (2010).

\begin{tabular}{|c|c|c|c|c|c|c|c|c|c|}
\hline \multirow{2}{*}{$\begin{array}{l}\text { Rock type } \\
\text { Analysis } \\
(\%)\end{array}$} & \multicolumn{3}{|c|}{ Hornblendite } & \multicolumn{6}{|c|}{ Vrm-phlogopitite/Clinopyroxenite } \\
\hline & $\begin{array}{c}\text { AM20_ } \\
\text { C5_90 }\end{array}$ & $\begin{array}{l}\text { FS33C_ } \\
\text { cpII_12 }\end{array}$ & $\begin{array}{c}\text { FS33C_- } \\
\text { cpII_9 }\end{array}$ & $\begin{array}{l}\text { FS17_ } \\
\text { cpIV__15 }\end{array}$ & $\begin{array}{c}\text { Fs-123-I } \\
\text { CI_25 }\end{array}$ & $\begin{array}{l}\text { FS-123-I } \\
\text { CI_26 }\end{array}$ & $\begin{array}{l}\text { FS-151III } \\
\text { CII_17 }\end{array}$ & $\begin{array}{c}\text { Fs33A_ } \\
\text { CII_6 }\end{array}$ & $\begin{array}{l}\text { Fs33A } \\
\text { _CI_14 }\end{array}$ \\
\hline $\mathrm{SiO}_{2}$ & 28.88 & 30.05 & 30.65 & 31.12 & 29.59 & 29.59 & 30.01 & 30.07 & 29.89 \\
\hline $\mathrm{TiO}_{2}$ & 39.42 & 40.10 & 37.79 & 37.59 & 39.37 & 40.69 & 37.85 & 38.95 & 38.67 \\
\hline $\mathrm{Al}_{2} \mathrm{O}_{3}$ & 1.57 & 0.91 & 0.89 & 1.15 & 0.41 & 0.28 & 1.43 & 0.67 & 0.92 \\
\hline $\mathrm{Cr}_{2} \mathrm{O}_{3}$ & 0.03 & 0.04 & 0.01 & 0.57 & 0.34 & 0.37 & 0.17 & 0.38 & 0.63 \\
\hline $\mathrm{Fe}_{2} \mathrm{O}_{3}$ & 0.51 & 0.67 & 0.73 & 0.74 & 0.48 & 0.30 & 0.45 & 0.54 & 0.74 \\
\hline $\mathrm{MnO}$ & 0.06 & 0.18 & 0.17 & 0.00 & 0.00 & 0.02 & 0.03 & 0.05 & 0.02 \\
\hline $\mathrm{MgO}$ & 0.00 & 0.02 & 0.00 & 0.00 & 0.02 & 0.00 & 0.03 & 0.00 & 0.04 \\
\hline $\mathrm{CaO}$ & 28.11 & 28.11 & 28.18 & 28.42 & 27.81 & 27.81 & 28.52 & 27.73 & 27.37 \\
\hline $\mathrm{Na}_{2} \mathrm{O}$ & 0.01 & 0.00 & 0.00 & 0.08 & 0.00 & 0.04 & 0.02 & 0.00 & 0.03 \\
\hline $\mathrm{K}_{2} \mathrm{O}$ & 0.00 & 0.01 & 0.02 & 0.08 & 0.03 & 0.08 & 0.00 & 0.00 & 0.00 \\
\hline $\mathrm{NiO}$ & 0.11 & 0.02 & 0.03 & 0.00 & 0.03 & 0.01 & 0.03 & 0.08 & 0.05 \\
\hline $\mathrm{BaO}$ & 0.14 & 0.00 & 0.00 & 0.00 & 0.18 & 0.09 & 0.11 & 0.28 & 0.20 \\
\hline $\mathrm{P}_{2} \mathrm{O}_{5}$ & 0.05 & 0.04 & 0.04 & 0.00 & 0.06 & 0.06 & 0.00 & 0.04 & 0.14 \\
\hline $\mathrm{SrO}$ & 0.00 & 0.00 & 0.00 & 0.00 & 0.10 & 0.00 & 0.01 & 0.13 & 0.02 \\
\hline $\mathrm{ZnO}$ & 0.08 & 0.00 & 0.00 & 0.00 & 0.05 & 0.01 & 0.00 & 0.02 & 0.00 \\
\hline $\mathrm{Cl}$ & 0.01 & 0.01 & 0.01 & 0.02 & 0.01 & 0.00 & 0.01 & 0.00 & 0.00 \\
\hline $\mathrm{F}$ & na & 0.03 & 0.00 & 0.00 & 0.00 & 0.00 & 0.08 & 0.00 & 0.00 \\
\hline $\mathrm{H}_{2} \mathrm{O}$ & 0.77 & 0.00 & 1.09 & 0.00 & 1.54 & 0.65 & 1.29 & 1.05 & 1.29 \\
\hline Total & 99.23 & 100.51 & 100.00 & 100.22 & 100.00 & 100.00 & 100.00 & 100.00 & 100.00 \\
\hline \multicolumn{10}{|c|}{ number of ions on the base of 5 oxygens } \\
\hline $\mathrm{Si}$ & 0.95 & 0.98 & 1.02 & 1.02 & 0.99 & 0.98 & 0.99 & 1.00 & 0.99 \\
\hline $\mathrm{Ti}$ & 0.97 & 0.99 & 0.94 & 0.93 & 0.99 & 1.01 & 0.94 & 0.97 & 0.97 \\
\hline $\mathrm{Al}$ & 0.06 & 0.03 & 0.03 & 0.04 & 0.02 & 0.01 & 0.06 & 0.03 & 0.04 \\
\hline $\mathrm{Cr}$ & 0.00 & 0.00 & 0.00 & 0.01 & 0.01 & 0.01 & 0.00 & 0.01 & 0.02 \\
\hline $\mathrm{Fe}^{3+}$ & 0.01 & 0.02 & 0.02 & 0.02 & 0.01 & 0.01 & 0.01 & 0.02 & 0.02 \\
\hline $\mathrm{Mn}^{3+}$ & 0.00 & 0.01 & 0.00 & 0.00 & 0.00 & 0.00 & 0.00 & 0.00 & 0.00 \\
\hline $\mathrm{Mg}$ & 0.00 & 0.00 & 0.00 & 0.00 & 0.00 & 0.00 & 0.00 & 0.00 & 0.00 \\
\hline $\mathrm{Ca}$ & 0.99 & 0.98 & 1.00 & 1.00 & 0.99 & 0.98 & 1.01 & 0.99 & 0.97 \\
\hline $\mathrm{Na}$ & 0.00 & 0.00 & 0.00 & 0.00 & 0.00 & 0.00 & 0.00 & 0.00 & 0.00 \\
\hline $\mathrm{K}$ & 0.00 & 0.00 & 0.00 & 0.00 & 0.00 & 0.00 & 0.00 & 0.00 & 0.00 \\
\hline $\mathrm{Ni}$ & 0.00 & 0.00 & 0.00 & 0.00 & 0.00 & 0.00 & 0.00 & 0.00 & 0.00 \\
\hline $\mathrm{Zn}$ & 0.00 & 0.00 & 0.00 & 0.00 & 0.00 & 0.00 & 0.00 & 0.00 & 0.00 \\
\hline $\mathrm{Ba}$ & 0.00 & 0.00 & 0.00 & 0.00 & 0.00 & 0.00 & 0.00 & 0.00 & 0.00 \\
\hline $\mathrm{Cl}$ & 0.00 & 0.00 & 0.00 & 0.00 & 0.00 & 0.00 & 0.00 & 0.00 & 0.00 \\
\hline $\mathrm{F}$ & na & 0.00 & 0.00 & 0.00 & 0.00 & 0.00 & 0.01 & 0.00 & 0.00 \\
\hline $\mathrm{OH}$ & 0.08 & 0.05 & 0.06 & 0.06 & 0.03 & 0.02 & 0.06 & 0.04 & 0.06 \\
\hline Cations & 3.00 & 3.01 & 3.02 & 3.03 & 3.01 & 3.01 & 3.03 & 3.01 & 3.02 \\
\hline
\end{tabular}

As lamelas alteradas da flogopita e vermiculita da população II (Fig. 12) ocorrem associadas ao vrm-flogopitito e apresentam variações de $\mathrm{MgO}$ e $\mathrm{Al}_{2} \mathrm{O}_{3}$ inferiores a população I. Os teores de $\mathrm{MgO}, \mathrm{Fe}_{2} \mathrm{O}_{3}, \mathrm{TiO}_{2}, \mathrm{Al}_{2} \mathrm{O}_{3}, \mathrm{~K}_{2} \mathrm{O}$ e $\mathrm{H}_{2} \mathrm{O}$ total variam de 20,53 a $28,13 \%, 4,62$ a $10,24 \%, 0,56$ a 2,00\%, 11,41 a $14,30 \%, 0,0$ a 9,68\% e 6,11 a $22,39 \%$.

As lamelas alteradas da flogopita e vermiculita da população II (Fig. 12) ocorrem associadas ao vrm-flogopitito e apresentam variações de $\mathrm{MgO}$ e $\mathrm{Al}_{2} \mathrm{O}_{3}$ inferiores a população I. Os teores de $\mathrm{MgO}, \mathrm{Fe}_{2} \mathrm{O}_{3}, \mathrm{TiO}_{2}, \mathrm{Al}_{2} \mathrm{O}_{3}, \mathrm{~K}_{2} \mathrm{O}$ e $\mathrm{H}_{2} \mathrm{O}$ total variam 
de 20,53 a $28,13 \%, 4,62$ a $10,24 \%, 0,56$ a $2,00 \%, 11,41$ a $14,30 \%, 0,0$ a $9,68 \%$ e 6,11 a $22,39 \%$.
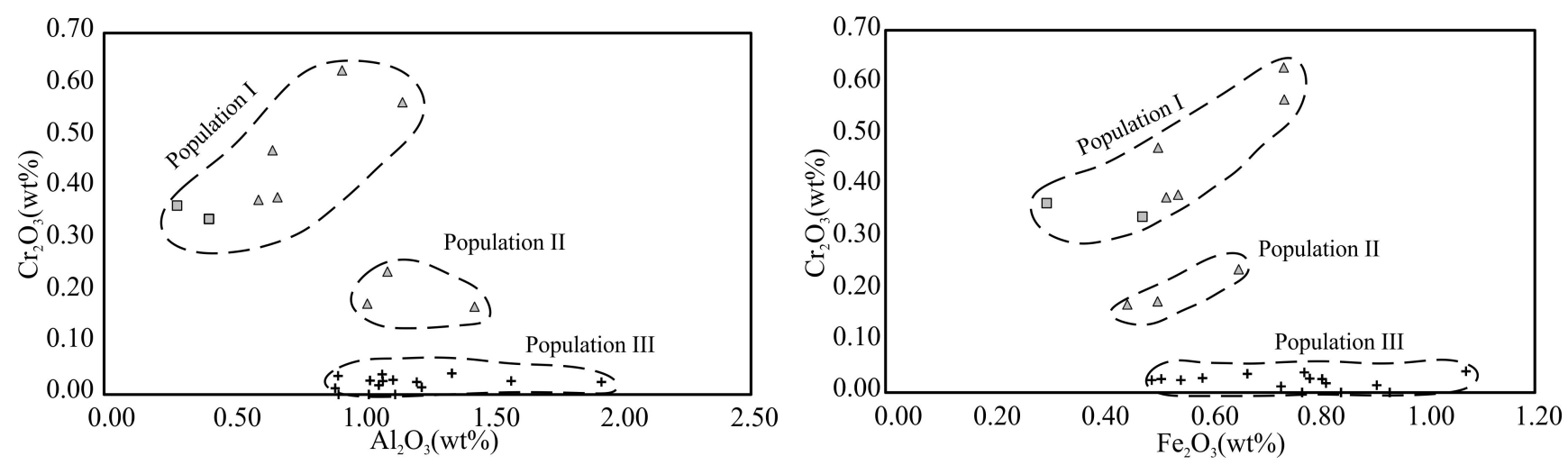

Clinopyroxenite $\triangle$ Vrm-phlogopitite + Hornblendite

Figura 11 - Diagrama com teores de $\mathrm{Cr}_{2} \mathrm{O}_{3}$ (wt\%) em função de $\mathrm{Al}_{2} \mathrm{O}_{3}$ (wt $\%$ ) e $\mathrm{Fe}_{2} \mathrm{O}_{3}$ (wt \%) dos cristais de titanita

As lamelas da população I possuem menores teores de titânio em relação à população II, pois são derivadas de flogopita empobrecida por causa do processo de exsolução da ilmenita. A vermiculita da população II possui alto teor de titânio, pois são derivadas de lamelas de flogopita com elevado conteúdo deste elemento.

\section{Litogeoquímica}

Análise de química de rocha total para elementos maiores, menores e traços (Tabela 8) foram obtidas para 31 amostras de 3 afloramentos e 6 testemunhos de furos de sondagem. As amostras selecionadas compreendem rochas ígneas, derivados hidrotermais e hornblenditos que ocorrem na SSLMB. A taxa de perda ao fogo (LOI) fornece o grau aproximado de hidratação pós-magmática das rochas primárias. $\mathrm{O}$ ferro total das amostras foi fornecido pelos laboratórios como $\mathrm{Fe}_{2} \mathrm{O}_{3}$.

\subsection{Elementos maiores e menores}

Com o objetivo de reconhecer o comportamento dos elementos ao longo da estratigrafia dos corpos ultramáficos da SSLMB, uma amostra de cada litologia encontrada no furo de sonda FS90 foi encaminhada para análise de geoquímica de rocha total (Fig. 13). Ao longo do perfil, uma feição notável está associada à alteração de clinopiroxenito para vrm-flogopitito, envolvendo uma concentração gradualmente maior 
de potássio, alumínio e bário, assim como uma importante perda de cálcio. Entre srpmt-vrm-flogopitito e vrm-flogopitito há um declínio brusco nas concentrações de potássio, alumínio, titânio, cromo e bário e um pequeno aumento de cálcio. A camada de srp-mt-vrm - flogopitito é enriquecida em níquel e magnésio, porém com menor conteúdo de titânio em relação às camadas de clinopiroxenito.

Tabela 7 - Dados representativos de hidroflogopita e vermiculita. H2O-** água na estrutura e H2O+*água entre as camadas. Abreviação mineral segundo Whitney e Evans (2010).

\begin{tabular}{|c|c|c|c|c|c|c|c|c|c|c|}
\hline $\begin{array}{l}\text { Rock } \\
\text { type }\end{array}$ & \multicolumn{5}{|c|}{ Srp-mt-vrm-phlogopitite } & \multicolumn{5}{|c|}{ Vrm-phlogopitite } \\
\hline Type & \multicolumn{5}{|c|}{ I } & \multicolumn{5}{|c|}{ II } \\
\hline $\begin{array}{l}\text { Analysis } \\
\text { wt }(\%)\end{array}$ & $\begin{array}{c}\text { FS-101- } \\
\text { III } \\
\text { CIV_1 }\end{array}$ & $\begin{array}{c}\text { FS-101- } \\
\text { III } \\
\text { CIV_2 }\end{array}$ & $\begin{array}{l}\text { FS-101- } \\
\text { III_CI }\end{array}$ & $\begin{array}{l}\text { Prata2 } \\
\text { Lm4_8 }\end{array}$ & $\begin{array}{l}\text { Prata1 } \\
\text { Lm2_5 }\end{array}$ & $\begin{array}{l}\text { Bronze1 } \\
\text { Lm2_4 }\end{array}$ & $\begin{array}{l}\text { Bronze1 } \\
\text { Lm7_13 }\end{array}$ & $\begin{array}{c}\text { Bronze1 } \\
\text { Lm11_Vrm19 }\end{array}$ & $\begin{array}{l}\text { Bronze1 } \\
\text { Lm12_23 }\end{array}$ & $\begin{array}{l}\text { Bronze2 } \\
\text { Lm8_16 }\end{array}$ \\
\hline $\mathrm{SiO}_{2}$ & $33 . \overline{87}$ & $38 . \overline{71}$ & 35.00 & 39.05 & 39.39 & 39.02 & 37.24 & 36.36 & 37.74 & 38.06 \\
\hline $\mathrm{TiO}_{2}$ & 0.10 & 0.27 & 0.12 & 0.20 & 0.08 & 1.37 & 1.74 & 1.11 & 1.84 & 1.74 \\
\hline $\mathrm{Al}_{2} \mathrm{O}_{3}$ & 13.18 & 12.47 & 11.50 & 10.26 & 10.33 & 13.91 & 13.21 & 13.89 & 13.41 & 13.65 \\
\hline $\mathrm{Cr}_{2} \mathrm{O}_{3}$ & 0.06 & 0.22 & 0.22 & 0.44 & 0.30 & 0.73 & 0.81 & 0.35 & 0.57 & 0.65 \\
\hline $\mathrm{Fe}_{2} \mathrm{O}_{3}$ & 3.35 & 2.88 & 4.60 & 3.24 & 2.73 & 7.77 & 7.13 & 10.24 & 6.27 & 7.52 \\
\hline $\mathrm{MnO}$ & 0.01 & 0.00 & 0.10 & 0.06 & 0.00 & 0.00 & 0.00 & 0.22 & 0.00 & 0.11 \\
\hline $\mathrm{MgO}$ & 34.34 & 30.18 & 36.33 & 30.58 & 30.24 & 22.77 & 20.58 & 21.41 & 23.95 & 22.97 \\
\hline $\mathrm{CaO}$ & 0.17 & 0.04 & 0.03 & 0.01 & 0.08 & 0.13 & 0.08 & 0.13 & 0.05 & 0.06 \\
\hline $\mathrm{Na}_{2} \mathrm{O}$ & 0.13 & 0.12 & 0.00 & 0.15 & 0.11 & 0.02 & 0.00 & 0.04 & 0.30 & 0.08 \\
\hline $\mathrm{K}_{2} \mathrm{O}$ & 1.52 & 6.62 & 0.06 & 0.05 & 0.08 & 0.05 & 0.07 & 0.17 & 0.08 & 0.18 \\
\hline $\mathrm{NiO}$ & 0.12 & 0.20 & 0.18 & 0.21 & 0.19 & 0.23 & 0.17 & 0.07 & 0.21 & 0.17 \\
\hline $\mathrm{BaO}$ & 0.07 & 0.15 & 0.00 & 0.00 & 0.05 & 0.00 & 0.02 & 0.00 & 0.05 & 0.06 \\
\hline $\mathrm{ZnO}$ & 0.00 & 0.08 & 0.00 & 0.05 & 0.00 & 0.00 & 0.09 & 0.00 & 0.04 & 0.00 \\
\hline $\mathrm{Cl}$ & 0.06 & 0.03 & 0.03 & 0.03 & 0.02 & 0.01 & 0.00 & 0.00 & 0.01 & 0.00 \\
\hline $\mathrm{F}$ & 0.00 & 0.21 & 0.00 & 0.22 & 0.23 & 0.39 & 0.09 & 0.27 & 0.34 & 0.21 \\
\hline H2O-** & 4.04 & 4.20 & 4.10 & 3.91 & 3.90 & 3.90 & 3.80 & 3.76 & 3.85 & 3.90 \\
\hline $\mathrm{H} 2 \mathrm{O}+* *$ & 8.99 & 3.62 & 7.72 & 11.52 & 12.28 & 9.71 & 14.98 & 11.97 & 11.31 & 10.64 \\
\hline $\mathrm{O}=\mathrm{F}, \mathrm{Cl}$ & -0.01 & -0.09 & -0.01 & -0.1 & -0.1 & -0.17 & -0.04 & -0.12 & -0.15 & -0.09 \\
\hline Total & 100.01 & 100.09 & 100.01 & 100.1 & 100.1 & 100.17 & 100.04 & 100.12 & 100.15 & 100.09 \\
\hline \multicolumn{11}{|c|}{ number of ions on the basis of 11 oxygens } \\
\hline $\mathrm{Si}$ & 2.50 & 2.69 & 2.56 & 2.91 & 2.95 & 2.86 & 2.91 & 2.77 & 2.82 & 2.83 \\
\hline $\mathrm{Al}^{\mathrm{IV}}$ & 1.15 & 1.02 & 0.99 & 0.90 & 0.91 & 1.14 & 1.09 & 1.23 & 1.18 & 1.17 \\
\hline $\mathrm{Fe}^{3+}$ & 0.19 & 0.15 & 0.25 & 0.18 & 0.14 & 0.00 & 0.00 & 0.00 & 0.01 & 0.00 \\
\hline $\mathrm{Al}^{\mathrm{VI}}$ & 0.00 & 0.00 & 0.00 & 0.00 & 0.00 & 0.06 & 0.12 & 0.01 & 0.00 & 0.03 \\
\hline $\mathrm{Ti}$ & 0.01 & 0.01 & 0.01 & 0.01 & 0.00 & 0.08 & 0.10 & 0.06 & 0.10 & 0.10 \\
\hline $\mathrm{Cr}$ & 0.00 & 0.01 & 0.01 & 0.03 & 0.02 & 0.04 & 0.05 & 0.02 & 0.03 & 0.04 \\
\hline $\mathrm{Fe}^{3+}$ & 0.00 & 0.00 & 0.00 & 0.00 & 0.01 & 0.43 & 0.42 & 0.59 & 0.35 & 0.42 \\
\hline $\mathrm{Mn}$ & 0.00 & 0.00 & 0.01 & 0.01 & 0.00 & 0.00 & 0.00 & 0.02 & 0.00 & 0.01 \\
\hline $\mathrm{Ni}$ & 0.01 & 0.01 & 0.01 & 0.01 & 0.01 & 0.01 & 0.01 & 0.00 & 0.01 & 0.01 \\
\hline $\mathrm{Mg}$ & 2.98 & 2.96 & 2.96 & 2.95 & 2.96 & 2.38 & 2.29 & 2.29 & 2.50 & 2.39 \\
\hline $\mathrm{Mg}$ & 0.80 & 0.17 & 1.00 & 0.45 & 0.42 & 0.11 & 0.10 & 0.14 & 0.16 & 0.15 \\
\hline $\mathrm{Na}$ & 0.04 & 0.03 & 0.00 & 0.04 & 0.03 & 0.01 & 0.00 & 0.01 & 0.09 & 0.02 \\
\hline $\mathrm{Ca}$ & 0.02 & 0.00 & 0.00 & 0.00 & 0.01 & 0.01 & 0.01 & 0.01 & 0.01 & 0.01 \\
\hline K & 0.29 & 1.17 & 0.01 & 0.01 & 0.02 & 0.01 & 0.01 & 0.03 & 0.01 & 0.03 \\
\hline $\mathrm{Ba}$ & 0.00 & 0.00 & 0.00 & 0.00 & 0.00 & 0.00 & 0.00 & 0.00 & 0.00 & 0.00 \\
\hline $\mathrm{Zn}$ & 0.00 & 0.00 & 0.00 & 0.00 & 0.00 & 0.00 & 0.01 & 0.00 & 0.00 & 0.00 \\
\hline $\mathrm{OH}$ & 1.99 & 1.95 & 2.00 & 1.94 & 1.94 & 1.91 & 1.98 & 1.93 & 1.92 & 1.95 \\
\hline $\mathrm{Cl}$ & 0.01 & 0.00 & 0.00 & 0.00 & 0.00 & 0.00 & 0.00 & 0.00 & 0.00 & 0.00 \\
\hline $\mathrm{F}$ & 0.00 & 0.05 & 0.00 & 0.05 & 0.05 & 0.09 & 0.02 & 0.07 & 0.08 & 0.05 \\
\hline Cations & 7.98 & 8.25 & 7.81 & 7.50 & 7.48 & 7.14 & 7.13 & 7.20 & 7.24 & 7.22 \\
\hline
\end{tabular}




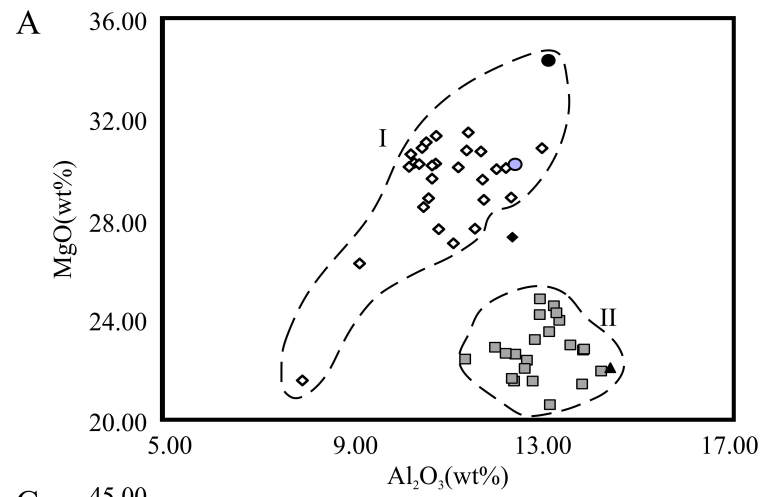

B
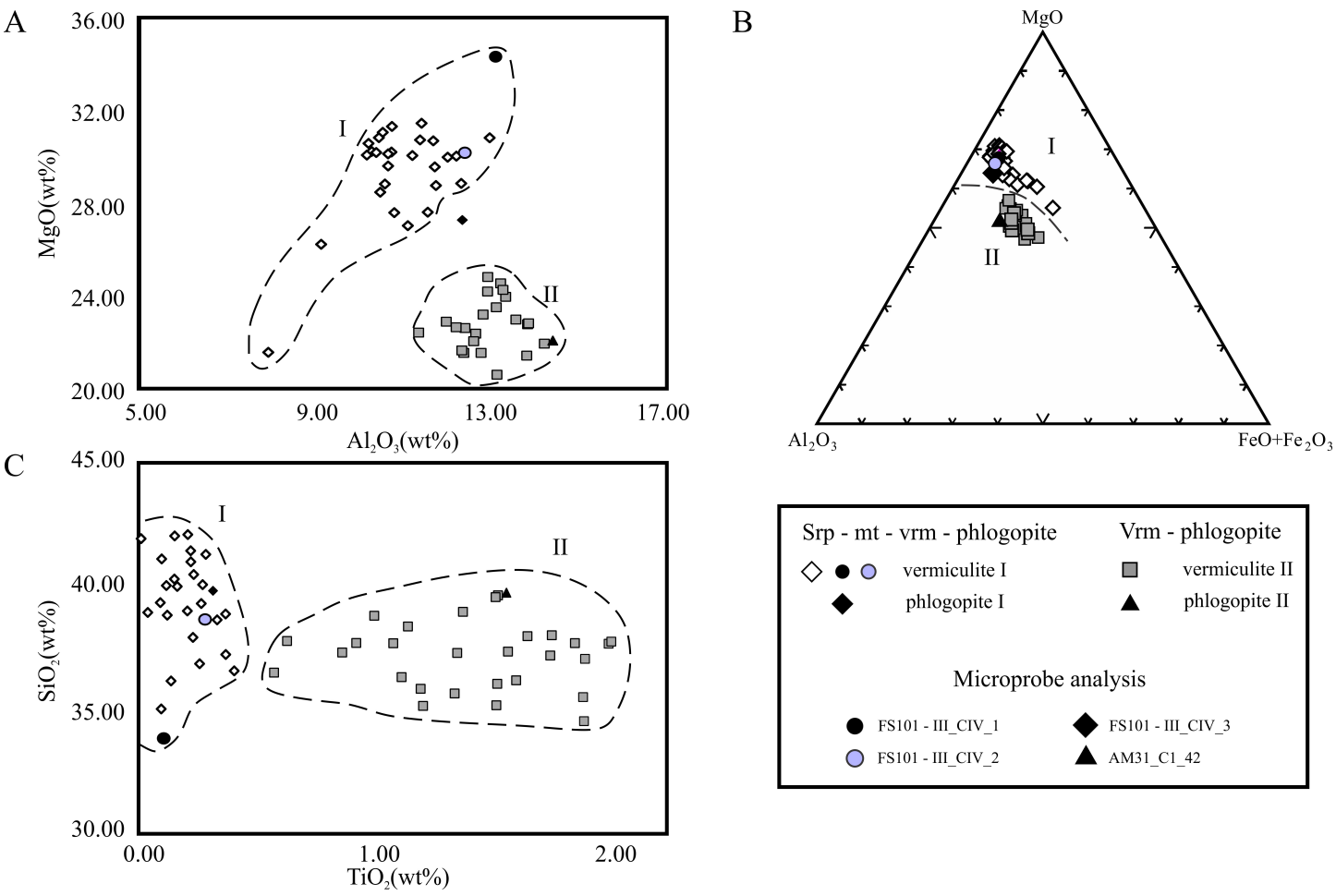

Figura 12 - A) B) e C) Diagramas $\mathrm{MgO}$ por $\mathrm{Al}_{2} \mathrm{O}_{3}$, ternário $\mathrm{MgO}, \mathrm{Al}_{2} \mathrm{O}_{3}$ e $\mathrm{FeO}+\mathrm{Fe}_{2} \mathrm{O}_{3}$ e $\mathrm{SiO}_{2}$ por $\mathrm{TiO}_{2}$ distinguindo dois tipos de população e comparado a lamelas de flogopita de srp-mt-vrm - flogopitito e vrm - flogopitito. Abreviação mineral segundo Whitney e Evans (2010).

\subsection{Elementos Traços}

Os teores de elementos terras raras leves (ETRL) e pesados (ETRP), normalizados ao condrito caracterizam diferentes tipos de rochas da SSLMB (Fig. 14). $\mathrm{O}$ perfil de elementos terras raras para wehrlito $\left((\mathrm{La} / \mathrm{Sm})_{\mathrm{N}}=1,72-1,75,(\mathrm{La} / \mathrm{Yb})_{\mathrm{N}}=\right.$ $10,04-11,27$ e $\left.(\mathrm{Gd} / \mathrm{Yb})_{\mathrm{N}}=3,64-4,73\right)$ clinopiroxenito $\left((\mathrm{La} / \mathrm{Sm})_{\mathrm{N}}=0,02-3,85\right.$, $(\mathrm{La} / \mathrm{Yb})_{\mathrm{N}}=0,12-26,72$ e $\left.(\mathrm{Gd} / \mathrm{Yb})_{\mathrm{N}}=3,97-6,96\right)$, possuem característica semelhantes com ambos apresentando um leve fracionamento entre concentrações de ETRL a ETRP e uma discreta anomalia negativa em $\mathrm{Eu}\left(\mathrm{Eu} / \mathrm{Eu}^{*}=0,78-0,83\right.$ para peridotitos e 0,77 1,01 para clinopiroxenitos) (Fig. 14A). Porém peridotitos possuem conteúdo total de elementos terras (ETR) inferior ao conteúdo dos clinopiroxenitos variando de 57,23 a 57,71 e 107,18 a 448,81, respectivamente.

Vrm-flogopitito apresenta conteúdo de ETRP $\left((\mathrm{La} / \mathrm{Sm})_{\mathrm{N}}=1,66-9,41\right)$ levemente inferiores em relação aos ETRL $\left((\mathrm{Gd} / \mathrm{Yb})_{\mathrm{N}}=4,83-5,86\right)$, com anomalia negativa discreta em $\mathrm{Eu}\left(\mathrm{Eu} / \mathrm{Eu}^{*}=0,78\right.$ - 1,94) (Fig. 14B), características semelhantes aos perfis de clinopiroxenito. Os perfis de Srp-mt-vrm-flogopitito são semelhantes a alguns perfis dos peridotitos com anomalias de $\mathrm{Yb}$ e $\mathrm{Lu}$. 
Tabela 8 - Análise de elementos maiores, menores e traços das rochas da SSLMB. As razões estão normalizadas ao condrito de Sun e McDonough (1989). *na = Não analisado.

\begin{tabular}{|c|c|c|c|c|c|c|c|c|c|c|c|c|}
\hline \multirow{2}{*}{$\begin{array}{l}\text { Rock type } \\
\text { Sample }\end{array}$} & & \multicolumn{2}{|c|}{ Wehrlite } & \multicolumn{9}{|c|}{ Clinopyroxenite } \\
\hline & & Fs 101 & $\begin{array}{c}\text { FS123 } \\
93.95 \mathrm{~m}\end{array}$ & $\begin{array}{c}\text { FS123 } \\
100.19 \\
\mathrm{~m}\end{array}$ & $\begin{array}{l}\text { FS123 } \\
90.92 \mathrm{~m}\end{array}$ & $\begin{array}{c}\text { Am- } \\
023\end{array}$ & $\begin{array}{c}\text { Fs-90 } \\
31.80 \mathrm{~m}\end{array}$ & $\begin{array}{c}\text { Fs-90 } \\
08.70 \mathrm{~m}\end{array}$ & $\begin{array}{c}\text { Fs-90 } \\
29.90 \mathrm{~m}\end{array}$ & $\begin{array}{c}\text { Fs-90 } \\
05.50 \mathrm{~m}\end{array}$ & $\begin{array}{c}\text { Fs-90 } \\
07.40 \mathrm{~m}\end{array}$ & $\begin{array}{c}\text { Fs-90 } \\
26.00 \mathrm{~m}\end{array}$ \\
\hline $\mathrm{SiO}_{2}$ & & 42.68 & 43.29 & 50.16 & 43.90 & 47.31 & 50.50 & 43.89 & 48.76 & 46.77 & 44.98 & 47.40 \\
\hline $\mathrm{Al}_{2} \mathrm{O}_{3}$ & & 7.29 & 3.02 & 4.13 & 8.49 & 6.85 & 5.35 & 7.66 & 6.05 & 7.17 & 7.61 & 7.80 \\
\hline $\mathrm{Fe}_{2} \mathrm{O}_{3 \text { total }}$ & & 7.61 & 10.76 & 5.52 & 9.79 & 7.41 & 7.99 & 8.65 & 7.87 & 7.41 & 8.64 & 8.06 \\
\hline $\mathrm{MnO}$ & & 0.09 & 0.15 & 0.11 & 0.12 & 0.12 & 0.15 & 0.09 & 0.13 & 0.09 & 0.09 & 0.11 \\
\hline $\mathrm{MgO}$ & & 23.42 & 33.37 & 17.24 & 18.26 & 17.87 & 16.43 & 18.30 & 16.58 & 18.75 & 17.64 & 17.83 \\
\hline $\mathrm{CaO}$ & & 4.60 & 2.25 & 15.13 & 9.48 & 12.12 & 15.66 & 10.08 & 15.21 & 9.14 & 10.41 & 11.29 \\
\hline $\mathrm{Na}_{2} \mathrm{O}$ & $\mathrm{wt}(\%)$ & 0.17 & 0.14 & 0.44 & 0.60 & 0.46 & 0.75 & 0.35 & 0.53 & 0.49 & 0.44 & 0.39 \\
\hline $\mathrm{K}_{2} \mathrm{O}$ & & 3.86 & 2.03 & 2.43 & 4.44 & 3.73 & 2.52 & 2.59 & 3.48 & 3.98 & 4.47 & 5.02 \\
\hline $\mathrm{TiO}_{2}$ & & 0.84 & 0.31 & 0.51 & 1.20 & 0.94 & 0.73 & 1.17 & 0.96 & 1.03 & 1.01 & 1.15 \\
\hline $\mathrm{P}_{2} \mathrm{O}_{5}$ & & 0.04 & 0.05 & 0.08 & 0.73 & 0.21 & 0.17 & 0.45 & 1.05 & 0.01 & 0.04 & 0.06 \\
\hline $\mathrm{Cr}_{2} \mathrm{O}_{3}$ & & 0.29 & 0.09 & 0.11 & 0.04 & 0.03 & 0.08 & 0.09 & 0.08 & 0.20 & 0.01 & 0.17 \\
\hline LOI & & 8.40 & 3.70 & 3.70 & 2.30 & 2.40 & 1.31 & 5.25 & 1.38 & 1.49 & 1.66 & 1.42 \\
\hline Total & & 99.44 & 99.37 & 99.61 & 99.42 & 99.46 & 101.63 & 98.57 & 102.09 & 96.48 & 97.00 & 100.72 \\
\hline$S$ & & 0.43 & 0.28 & 0.03 & 0.06 & 0.01 & na & na & na & na & na & na \\
\hline $\mathrm{C}$ & $\mathrm{wt}(\%)$ & 0.03 & 0.03 & 0.55 & 0.08 & 0.01 & na & na & na & na & na & na \\
\hline $\mathrm{Ni}$ & & 1067.00 & 1570.00 & 301.00 & 243.00 & 320.00 & 332.00 & 290.00 & 327.00 & 509.00 & 161.00 & 517.00 \\
\hline $\mathrm{Ba}$ & & 1161.00 & 357.00 & 501.00 & 1454.00 & 1151.00 & 887.00 & 920.00 & 1486.00 & 1457.00 & 1329.00 & 1563.00 \\
\hline V & & 128.00 & 56.00 & 135.00 & 272.00 & 202.00 & 142.00 & 204.00 & 144.00 & 164.00 & 181.00 & 171.00 \\
\hline $\mathrm{Co}$ & & 81.70 & 124.00 & 46.80 & 79.20 & 57.60 & 53.40 & 80.00 & 58.70 & 65.70 & 73.50 & 61.30 \\
\hline $\mathrm{Cu}$ & & 9.60 & 12.50 & 7.70 & 177.50 & 410.30 & 205.00 & 207.00 & 124.00 & 214.00 & 84.00 & 108.00 \\
\hline $\mathrm{Rb}$ & & 313.40 & 156.70 & 213.40 & 336.20 & 263.10 & 162.20 & 227.40 & 225.60 & 292.10 & 360.00 & 340.30 \\
\hline $\mathrm{Sr}$ & & 37.30 & 60.90 & 176.10 & 187.70 & 177.10 & 148.00 & 121.00 & 227.00 & 114.00 & 118.00 & 111.00 \\
\hline $\mathrm{Y}$ & & 1.80 & 1.90 & 5.30 & 8.00 & 8.50 & 9.45 & 9.65 & 11.45 & 6.73 & 6.55 & 6.40 \\
\hline $\mathrm{Zr}$ & & 11.20 & 11.50 & 11.50 & 11.60 & 21.10 & 51.00 & 61.00 & 49.00 & 60.00 & 55.00 & 52.00 \\
\hline $\mathrm{Nb}$ & & 0.80 & 0.20 & 0.70 & 0.80 & 1.90 & 0.01 & 3.24 & 0.01 & 5.34 & 3.65 & 0.01 \\
\hline $\mathrm{La}$ & & 2.20 & 2.10 & 4.90 & 9.80 & 8.90 & 14.80 & 5.70 & 18.30 & 0.05 & 0.20 & 14.90 \\
\hline $\mathrm{Ce}$ & & 3.90 & 4.80 & 12.80 & 24.10 & 22.50 & 24.30 & 18.10 & 40.90 & 11.40 & 9.90 & 18.60 \\
\hline $\operatorname{Pr}$ & & 0.58 & 0.67 & 1.89 & 3.59 & 3.17 & 2.80 & 2.70 & 4.59 & 1.58 & 1.55 & 2.01 \\
\hline $\mathrm{Nd}$ & & 3.30 & 3.20 & 9.70 & 17.80 & 15.70 & 20.30 & 12.30 & 31.70 & 5.70 & 6.40 & 14.10 \\
\hline $\mathrm{Sm}$ & & 0.81 & 0.79 & 2.83 & 4.15 & 4.26 & 4.00 & 3.40 & 5.70 & 1.80 & 2.10 & 2.50 \\
\hline $\mathrm{Cs}$ & (ppm) & 10.70 & 4.10 & 4.90 & 9.50 & 6.80 & 4.73 & 9.57 & 6.57 & 8.11 & 11.15 & 9.43 \\
\hline $\mathrm{Eu}$ & & 0.22 & 0.19 & 0.67 & 1.22 & 0.99 & 1.03 & 0.87 & 1.49 & 0.47 & 0.55 & 0.79 \\
\hline Gd & & 0.80 & 0.66 & 2.40 & 3.98 & 3.45 & 3.69 & 2.81 & 5.05 & 1.82 & 1.92 & 2.42 \\
\hline $\mathrm{Tb}$ & & 0.10 & 0.08 & 0.28 & 0.46 & 0.39 & 0.47 & 0.38 & 0.62 & 0.21 & 0.23 & 0.29 \\
\hline Dy & & 0.37 & 0.38 & 1.35 & 2.07 & 2.20 & 2.03 & 1.70 & 2.49 & 1.11 & 1.16 & 1.29 \\
\hline Ho & & 0.07 & 0.07 & 0.18 & 0.32 & 0.29 & 0.37 & 0.31 & 0.41 & 0.18 & 0.22 & 0.22 \\
\hline $\mathrm{Er}$ & & 0.18 & 0.15 & 0.53 & 0.70 & 0.72 & 0.80 & 0.75 & 0.90 & 0.51 & 0.49 & 0.48 \\
\hline $\mathrm{Tm}$ & & 0.03 & 0.01 & 0.07 & 0.10 & 0.11 & 0.09 & 0.09 & 0.09 & 0.01 & 0.07 & 0.01 \\
\hline $\mathrm{Yb}$ & & 0.14 & 0.15 & 0.43 & 0.66 & 0.56 & 0.60 & 0.40 & 0.60 & 0.30 & 0.40 & 0.40 \\
\hline $\mathrm{Ga}$ & & 5.00 & 0.80 & 3.20 & 7.70 & 8.10 & 6.10 & 10.00 & 6.40 & 8.60 & 9.40 & 7.70 \\
\hline $\mathrm{Lu}$ & & 0.02 & 0.01 & 0.05 & 0.08 & 0.08 & 0.06 & 0.05 & 0.06 & 0.01 & 0.01 & 0.01 \\
\hline $\mathrm{Hf}$ & & 0.30 & 0.30 & 0.40 & 0.50 & 0.70 & 0.01 & 0.40 & 0.01 & 0.47 & 0.32 & 0.01 \\
\hline Th & & 0.80 & 0.90 & 0.40 & 0.80 & 0.90 & 0.05 & 0.90 & 0.05 & 1.10 & 0.70 & 0.05 \\
\hline $\mathrm{U}$ & & 0.30 & $<0.1$ & 0.20 & 0.20 & 0.20 & 0.30 & 0.26 & 0.19 & 0.12 & 0.12 & 0.15 \\
\hline $\mathrm{Ta}$ & & $<0.1$ & $<0.1$ & $<0.1$ & $<0.1$ & 0.05 & 0.01 & 0.01 & 0.01 & 0.01 & 0.05 & 0.01 \\
\hline$(\mathrm{La} / \mathrm{Sm})_{\mathrm{N}}$ & & 1.75 & 1.72 & 1.12 & 1.52 & 1.35 & 2.39 & 1.08 & 2.07 & 0.02 & 0.06 & 3.85 \\
\hline$(\mathrm{La} / \mathrm{Yb})_{\mathrm{N}}$ & & 11.27 & 10.04 & 8.17 & 10.65 & 11.40 & 17.69 & 10.22 & 21.88 & 0.12 & 0.36 & 26.72 \\
\hline$(\mathrm{Gd} / \mathrm{Yb})_{\mathrm{N}}$ & & 4.73 & 3.64 & 4.62 & 4.99 & 5.10 & 5.09 & 5.81 & 6.96 & 5.02 & 3.97 & 5.00 \\
\hline $\mathrm{Eu} / \mathrm{Eu}^{*}$ & & 0.83 & 0.78 & 0.77 & 0.90 & 0.76 & 0.81 & 0.84 & 0.83 & 0.79 & 0.82 & 0.97 \\
\hline $\begin{array}{l}\text { Total } \\
\text { REE }\end{array}$ & & 57.23 & 55.71 & 170.04 & 298.07 & 273.06 & 313.11 & 218.27 & 448.81 & 107.18 & 116.36 & 232.37 \\
\hline $\mathrm{Nb} / \mathrm{Ta}$ & & - & - & - & - & 38 & 1 & 324 & 1 & 534 & 73 & 1 \\
\hline
\end{tabular}


Tabela 8 (continuação)

\begin{tabular}{|c|c|c|c|c|c|c|c|c|c|c|c|}
\hline \multirow{2}{*}{$\begin{array}{l}\text { Rock type } \\
\text { Sample }\end{array}$} & & \multicolumn{2}{|c|}{ Clinopyroxenite } & \multicolumn{3}{|c|}{ Vrm-phlogopitite } & \multicolumn{2}{|c|}{$\begin{array}{l}\text { Srp-mt-vrm- } \\
\text { phlogopitite }\end{array}$} & \multicolumn{2}{|c|}{ Hornblendite I } & \multirow{2}{*}{$\begin{array}{l}\text { Hornblendit } \\
\text { e II } \\
\text { Am27 }\end{array}$} \\
\hline & & $\begin{array}{c}\text { Fs-90 } \\
15.60 \mathrm{~m}\end{array}$ & $\begin{array}{c}\text { Fs-90 } \\
10.85 \mathrm{~m}\end{array}$ & $\begin{array}{c}\text { Fs-33 } \\
25.00 \mathrm{~m}\end{array}$ & $\begin{array}{c}\text { Fs-90 } \\
19.20 \mathrm{~m}\end{array}$ & $\begin{array}{c}\text { Fs } 17 \\
28.65 \mathrm{~m}\end{array}$ & $\begin{array}{c}\text { Fs-90 } \\
18.50 \mathrm{~m}\end{array}$ & $\begin{array}{c}\text { Fs-90 } \\
18.80 \mathrm{~m}\end{array}$ & Am-020 & $\begin{array}{c}\text { Fs-19 } \\
27.85 \mathrm{~m}\end{array}$ & \\
\hline $\mathrm{SiO}_{2}$ & & 46.89 & 44.77 & 41.65 & 41.35 & 41.11 & 39.48 & 40.24 & 43.34 & 47.51 & 50.10 \\
\hline $\mathrm{Al}_{2} \mathrm{O}_{3}$ & & 7.81 & 8.98 & 10.72 & 12.91 & 13.54 & 7.67 & 6.96 & 11.35 & 9.99 & 6.29 \\
\hline $\mathrm{Fe}_{2} \mathrm{O}_{3 \text { total }}$ & & 7.76 & 7.27 & 9.29 & 5.98 & 6.91 & 7.80 & 7.98 & 14.17 & 11.47 & 8.67 \\
\hline $\mathrm{MnO}$ & & 0.11 & 0.07 & 0.08 & 0.05 & 0.05 & 0.08 & 0.07 & 0.20 & 0.19 & 0.15 \\
\hline $\mathrm{MgO}$ & & 18.43 & 19.48 & 19.18 & 21.32 & 21.82 & 22.71 & 22.73 & 10.73 & 12.70 & 16.67 \\
\hline $\mathrm{CaO}$ & & 10.72 & 8.07 & 5.94 & 1.25 & 1.40 & 5.91 & 6.31 & 12.23 & 11.63 & 12.68 \\
\hline $\mathrm{Na}_{2} \mathrm{O}$ & Wt & 0.48 & 0.40 & 0.61 & 0.21 & 0.35 & 0.11 & 0.09 & 1.96 & 1.44 & 1.41 \\
\hline $\mathrm{K}_{2} \mathrm{O}$ & & 5.06 & 5.75 & 6.27 & 9.60 & 9.38 & 6.07 & 5.42 & 1.45 & 2.05 & 0.49 \\
\hline $\mathrm{TiO}_{2}$ & & 1.07 & 1.18 & 1.38 & 1.44 & 1.59 & 0.81 & 0.73 & 1.65 & 1.33 & 0.40 \\
\hline $\mathrm{P}_{2} \mathrm{O}_{5}$ & & 0.03 & 0.01 & 0.73 & 0.06 & 0.02 & 0.04 & 0.06 & 1.43 & 0.34 & 0.61 \\
\hline $\mathrm{Cr}_{2} \mathrm{O}_{3}$ & & 0.23 & 0.27 & 0.45 & 0.67 & 0.59 & 0.39 & 0.35 & 0.01 & 0.07 & 0.30 \\
\hline LOI & & 1.55 & 1.42 & 1.64 & 1.13 & 2.50 & 8.46 & 7.99 & 1.10 & 1.20 & 1.80 \\
\hline Total & & 100.1 & 97.65 & 97.94 & 95.96 & 99.38 & 99.52 & 98.94 & 99.59 & 99.93 & 99.65 \\
\hline$S$ & wt & na & na & na & $\mathrm{Na}$ & 0.01 & na & na & 0.01 & na & $<0.02$ \\
\hline $\mathrm{C}$ & $(\%)$ & na & na & na & $\mathrm{Na}$ & 0.15 & na & na & 0.02 & na & $<0.02$ \\
\hline $\mathrm{Ni}$ & & 539.00 & 642.00 & 743.00 & 1088.00 & 1085.00 & 1292.00 & 1342.00 & 122.00 & 277.00 & 403.00 \\
\hline $\mathrm{Ba}$ & & 1392.00 & 1871.00 & 2304.00 & 2263.00 & 1962.00 & 1019.00 & 934.00 & 549.00 & 1042.00 & 29.00 \\
\hline V & & 137.0 & 176.00 & 210.00 & 131.00 & 224.00 & 49.00 & 64.00 & 291.00 & 239.00 & 216.00 \\
\hline $\mathrm{Co}$ & & 59.70 & 71.00 & 73.20 & 69.20 & 72.40 & 93.70 & 101.50 & 50.40 & 64.70 & 52.20 \\
\hline $\mathrm{Cu}$ & & 53.00 & 51.00 & 49.00 & 9.00 & 7.50 & 64.00 & 93.00 & 62.70 & 54.00 & 0.40 \\
\hline $\mathrm{Rb}$ & & 357.30 & 443.80 & 470.50 & 649.60 & 728.70 & 457.70 & 421.90 & 49.70 & 107.20 & 2.80 \\
\hline $\mathrm{Sr}$ & & 81.00 & 96.00 & 210.00 & 5.00 & 38.20 & 15.00 & 24.00 & 587.20 & 284.00 & 192.80 \\
\hline $\mathrm{Y}$ & & 5.36 & 5.61 & 12.22 & 1.84 & 0.80 & 2.50 & 3.22 & 27.20 & 19.10 & 9.00 \\
\hline $\mathrm{Zr}$ & & 40.00 & 53.00 & 66.00 & 65.00 & 5.40 & 166.00 & 51.00 & 64.60 & 83.00 & 27.7 \\
\hline $\mathrm{Nb}$ & & 0.01 & 2.59 & 7.58 & 0.01 & 1.20 & 0.09 & 2.63 & 6.70 & 2.91 & 0.80 \\
\hline $\mathrm{La}$ & & 7.00 & 3.00 & 17.80 & 10.20 & 0.90 & 12.60 & 0.05 & 36.20 & 25.40 & 4.10 \\
\hline $\mathrm{Ce}$ & & 10.80 & 10.30 & 43.50 & 6.50 & 1.70 & 13.00 & 10.40 & 105.40 & 50.20 & 8.30 \\
\hline $\operatorname{Pr}$ & & 1.32 & 1.34 & 6.11 & 0.61 & 0.24 & 1.16 & 1.26 & 15.38 & 6.16 & 1.97 \\
\hline $\mathrm{Nd}$ & & 9.60 & 5.00 & 25.80 & 4.30 & 1.40 & 6.50 & 3.40 & 73.50 & 39.60 & 12.50 \\
\hline $\mathrm{Sm}$ & & 2.00 & 1.60 & 5.40 & 0.70 & 0.35 & 0.90 & 0.90 & 16.47 & 7.70 & 3.57 \\
\hline Cs & (ppm) & 9.21 & 13.42 & 12.96 & 20.47 & 17.80 & 14.66 & 12.74 & 2.80 & 3.78 & $<0.1$ \\
\hline $\mathrm{Eu}$ & & 0.64 & 0.52 & 1.30 & 0.44 & 0.09 & 0.21 & 0.17 & 3.71 & 2.02 & 0.96 \\
\hline $\mathrm{Gd}$ & & 2.05 & 1.50 & 4.25 & 0.67 & 0.35 & 0.79 & 0.91 & 12.78 & 7.41 & 3.52 \\
\hline $\mathrm{Tb}$ & & 0.22 & 0.23 & 0.50 & 0.05 & 0.03 & 0.07 & 0.09 & 1.28 & 0.94 & 0.45 \\
\hline Dy & & 1.11 & 0.93 & 2.11 & 0.34 & 0.13 & 0.43 & 0.44 & 6.79 & 4.01 & 2.04 \\
\hline Ho & & 0.17 & 0.19 & 0.39 & 0.01 & 0.02 & 0.06 & 0.08 & 0.95 & 0.70 & 0.34 \\
\hline $\mathrm{Er}$ & & 0.44 & 0.44 & 0.84 & 0.12 & 0.05 & 0.21 & 0.26 & 2.10 & 1.75 & 0.91 \\
\hline $\mathrm{Tm}$ & & 0.01 & 0.01 & 0.11 & 0.01 & 0.01 & 0.01 & 0.01 & 0.29 & 0.20 & 0.12 \\
\hline $\mathrm{Yb}$ & & 0.40 & 0.30 & 0.60 & 0.10 & 0.06 & 0.20 & 0.20 & 1.74 & 1.30 & 0.77 \\
\hline $\mathrm{Ga}$ & & 7.80 & 10.80 & 13.00 & 12.00 & 11.90 & 7.10 & 8.20 & 16.80 & 13.90 & 6.50 \\
\hline $\mathrm{Lu}$ & & 0.01 & 0.01 & 0.08 & 0.01 & 0.01 & 0.01 & 0.01 & 0.22 & 0.15 & 0.11 \\
\hline $\mathrm{Hf}$ & & 0.01 & 0.30 & 0.69 & 0.12 & 0.05 & 2.36 & 0.41 & 2.20 & 0.49 & 1.00 \\
\hline Th & & 0.05 & 0.60 & 2.20 & 0.05 & 0.20 & 0.05 & 1.10 & 2.10 & 0.05 & 0.40 \\
\hline $\mathrm{U}$ & & 0.01 & 0.22 & 0.51 & 0.20 & 0.05 & 0.79 & 0.83 & 0.70 & 1.89 & 0.70 \\
\hline $\mathrm{Ta}$ & & 0.01 & 0.12 & 0.13 & 0.01 & 0.10 & 0.01 & 0.15 & 0.10 & 0.01 & $<0.1$ \\
\hline$(\mathrm{La} / \mathrm{Sm})_{\mathrm{N}}$ & & 2.26 & 1.21 & 2.13 & 9.41 & 1.66 & 9.04 & 0.04 & 1.42 & 2.13 & 0.74 \\
\hline$(\mathrm{La} / \mathrm{Yb})_{\mathrm{N}}$ & & 12.55 & 7.17 & 21.28 & 73.16 & 10.76 & 45.19 & 0.18 & 14.92 & 14.01 & 3.82 \\
\hline$(\mathrm{Gd} / \mathrm{Yb})_{\mathrm{N}}$ & & 4.24 & 4.14 & 5.86 & 5.54 & 4.83 & 3.27 & 3.76 & 6.08 & 4.72 & 3.78 \\
\hline $\mathrm{Eu} / \mathrm{Eu}^{*}$ & & 0.96 & 1.01 & 0.80 & 1.94 & 0.78 & 0.74 & 0.57 & 0.75 & 0.81 & 0.82 \\
\hline Total REE & & 151.6 & 109.98 & 434.04 & 96.55 & 23.00 & 131.64 & 66.66 & 1131.27 & 612.87 & 205.56 \\
\hline $\mathrm{Nb} / \mathrm{Ta}$ & & 1 & 21.58 & 58.31 & 1 & 12 & 9 & 17.53 & 67 & 291 & - \\
\hline
\end{tabular}




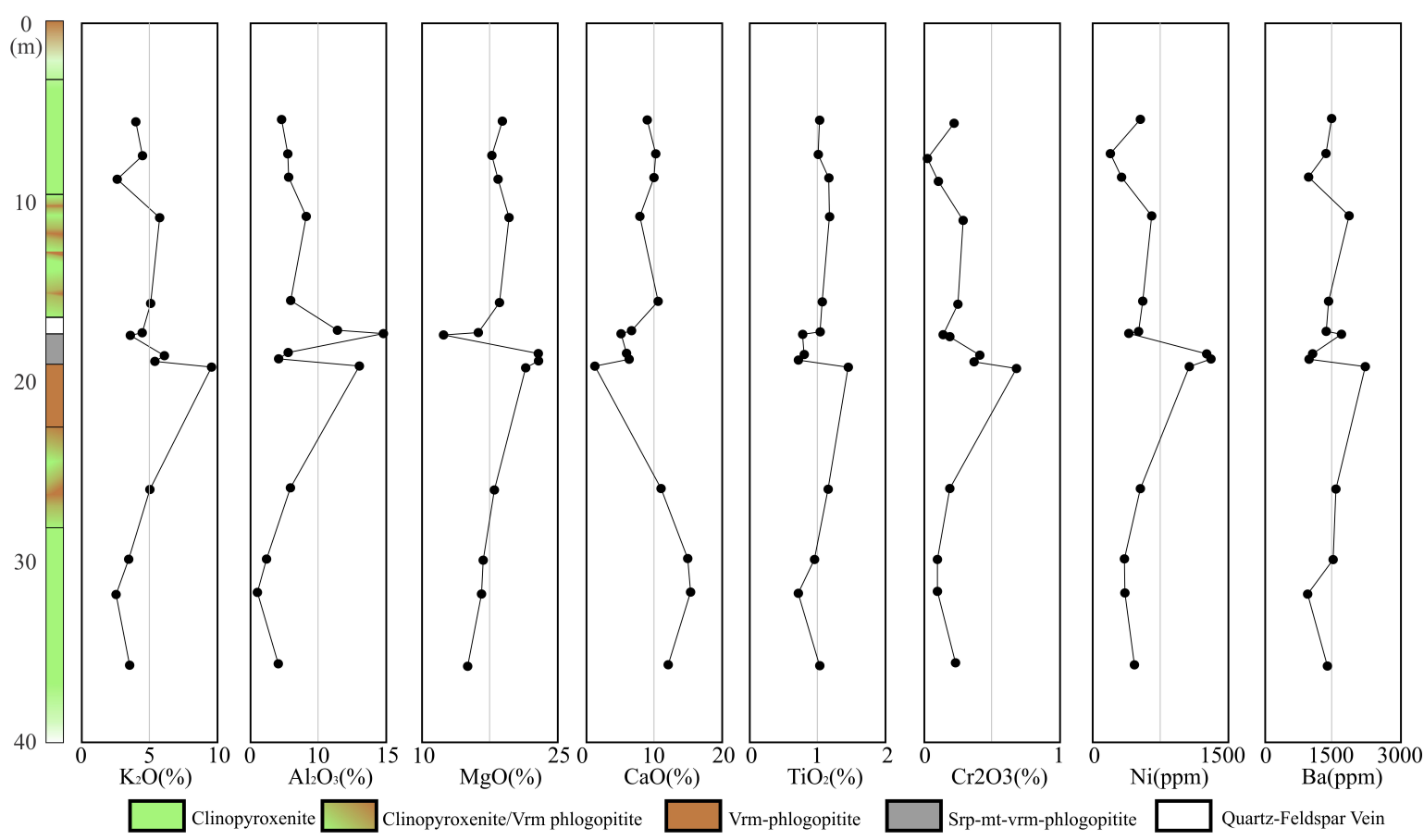

Figura 13 - Variação de $\mathrm{K}_{2} \mathrm{O}, \mathrm{Al}_{2} \mathrm{O}_{3}, \mathrm{MgO}, \mathrm{CaO}, \mathrm{TiO}_{2}, \mathrm{Cr}_{2} \mathrm{O}_{3}$, $\mathrm{Ni}$ e $\mathrm{Ba}$ ao longo do furo FS90. Abreviação mineral segundo Whitney e Evans (2010).

Os perfis para os horblenditos são distintos. Os hornblenditos do tipo I possuem perfis semelhante aos perfis de clinopiroxenito, com declínio suave das concentrações de $\operatorname{ETRL}\left((\mathrm{La} / \mathrm{Sm})_{\mathrm{N}}=1,42-2,30\right)$ para $\operatorname{ETRP}\left((\mathrm{Gd} / \mathrm{Yb})_{\mathrm{N}}=4,72-6,08\right)$ e uma pequena anomalia negativa em $\mathrm{Eu}\left(\mathrm{Eu} / \mathrm{Eu}^{*}=0,75-0,81\right)$. Os horblenditos do tipo II possuem concentrações de ETR inferiores aos do tipo I e um leve empobrecimento de ETRP $\left((\mathrm{Gd} / \mathrm{Yb})_{\mathrm{N}}=3,78\right)$ em relação a ETRL $\left((\mathrm{La} / \mathrm{Sm})_{\mathrm{N}}=0,74\right)$ e uma discreta anomalia em $\mathrm{Eu}\left(\mathrm{Eu} / \mathrm{Eu}^{*}=0,82\right)$.

As rochas ígneas da SSLMB e seus equivalentes hidrotermais normalizados ao Condrito obtiveram diferentes perfis para os elementos incompatíveis móveis e imóveis. (Fig. 15). Wehrlito, clinopiroxenito e seus derivados hidrotermais possuem comportamento semelhante, com perfil definindo tendência positiva para os elementos móveis e anomalias negativas em Nb, Ta, P e Hf. O hornblendito do tipo I possui perfil semelhante às intrusões ultramáficas, porém o hornblendito tipo II possui o perfil diferenciado das demais rochas por possuir tendência negativa para os elementos móveis.

De modo geral todas as rochas da Suíte São Luís de Montes Belos possuem anomalias negativas em Nb, Ta e Hf (Fig. 15) que são características típicas de rochas vulcânicas de ambiente de arco (Zhou et al., 2004). O elemento P é insensível a processos hidrotermais (Rollinson, 1993), por isso é pouco enriquecido ou pouco 
empobrecido nas rochas. $\mathrm{O}$ enriquecimento dos elementos $\mathrm{K}, \mathrm{Rb}$ e $\mathrm{Ba}$ são devido a ocorrência de flogopita.
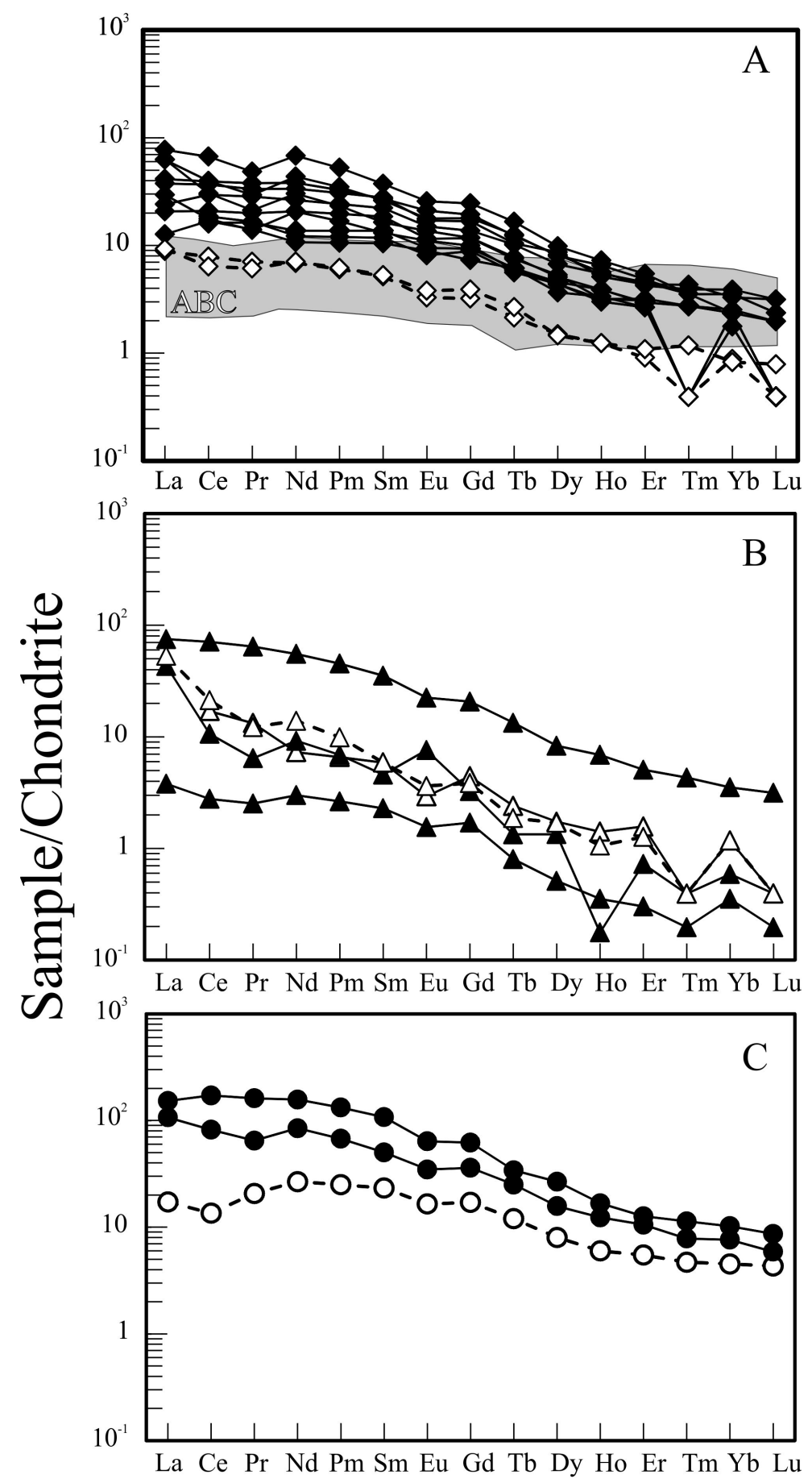

\begin{tabular}{ll|}
\hline$\diamond$ Wehrlite & $\Delta$ Srp-mt-vrm-phlogopitite \\
$\diamond$ Clinopyroxenite & $\Delta$ Vrm-phlogopitite \\
$\bullet$ Hornblendite I & O Hornblendite II \\
\hline
\end{tabular}

Figura 14 - Elementos terras raras normalizado ao Condrito para as amostras da SSLMB. A) Dunito, wehrlito e clinopiroxenito comparados aos valores das rochas ultramáficas do Complexo Americano do Brasil (ABC) (Mota e Silva et al., 2011). B) Srp-mt-vrm-flogopitito e Vrm-flogopitito e C) hornblendito. Normalizado pelos valores de Sun e McDonough (1989). 


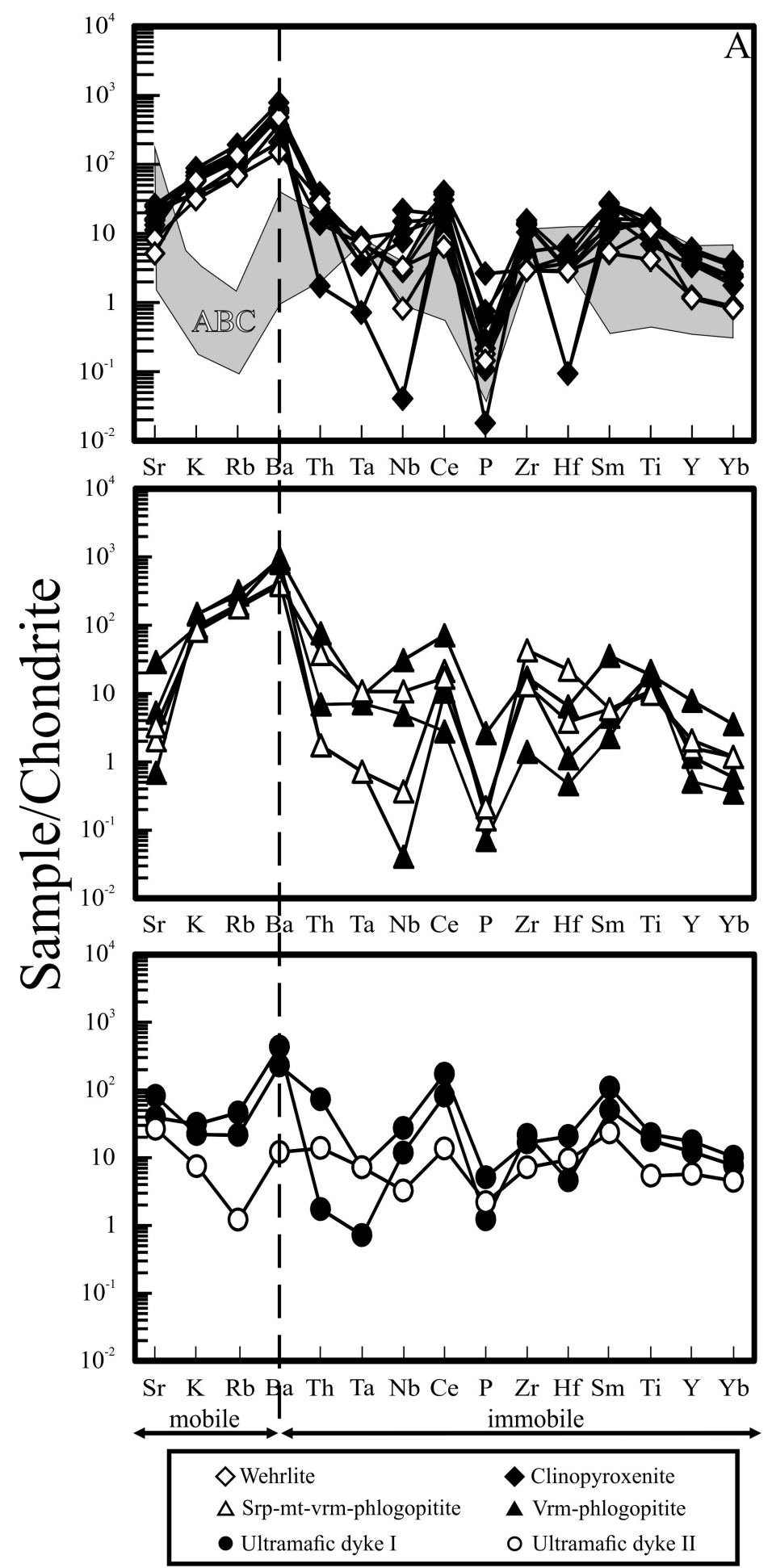

Figura 15 - Elementos-traço normalizados ao Condrito (Sun e McDonough, 1989).para A) Wehrlito e Clinopiroxenito comparados com os valores de ABC (Mota e Silva et al., 2011). B) Srp-mt-vrm-flogopitito e vrm-flogopitito e C) Hornbledito.

\section{U-Pb Geocronologia}

A titanita pode incorporarar quantidades significativas de urânio em sua estrutura cristalina (10 a 100 ppm de U; Frost et al., 2000), por tanto são excelentes 
indicadores de cristalização ígnea, metamórfica ou por processos hidrotermais (Della Giustina, 2007). Os critais de titanita geralmente se formam em temperaturas entre 650 e $700^{\circ} \mathrm{C}$ (Essex et al., 1997; Schärer et al.,1994; Verts et al., 1996), porém as titanitas com elevado conteúdo de alumínio (vide tópico 6.5) se formam em temperaturas menores, entre 300 e $400^{\circ} \mathrm{C}$ (Enami, 1993).

De uma amostra de vrm-flogopitito (Am 31), foram selecionados vinte um grãos de titanita para datação U-Pb. A amostra é composta por noventa por cento de flogopita da população II, sem inclusões de ilmenita, nove por cento de clinopiroxênio parcialmente substituídos para tremolita, um por cento de titanita intersticial e plagoclásio (Ab 94\%) como mineral acessório (Figs. 5D e 5E). Os cristais de titanita ocorrem associados à alteração de diopsídio para flogopita e possuem concentrações de $\mathrm{Cr}_{2} \mathrm{O}_{3}$ entre 0,18 e $0,57 \%$, correspondentes às populações de titanita I e II (Fig. 11).

As análises de U-Pb (Tabela 9) foram obtidas em grãos anédricos, transparentes, de coloração amarela clara, desprovidos de zonação, inclusões minerais, ou fratura. Os dados foram plotados em um diagrama Tera-Wasserburg (Fig. 16) e permitiram a definição de uma discórdia com intercepto ${ }^{207} \mathrm{~Pb} /{ }^{206} \mathrm{~Pb}$ inferior de $556 \pm 19 \mathrm{Ma}$ (MSWD $=3,6$ ), interpretado como a idade do evento metassomático responsável pela formação de vermiculita I a partir de flogopita I.

\section{Sistemática Sm-Nd}

Foram realizadas análises isotópicas de $\mathrm{Sm}-\mathrm{Nd}$ nos corpos ultramáficos (peridotitos, clinopiroxenito e srp-mt-vrm - flogopitito), hornblenditos e hornblenda gnaisse, encaixantes das rochas ultramáficas (Tabela 10).

Peridotitos e clinopiroxenito exibiram resultados $\varepsilon \mathrm{Nd}(\mathrm{T}=604 \mathrm{Ma}$, idade do fechamento da Faixa Brasília - Pimentel et al., 2001) entre -3,3 e -5.5. Os hornblenditos e srp-mt-vrm-flogopitito apresentaram $\varepsilon \mathrm{Nd}(\mathrm{T}=556 \mathrm{Ma}$, datação em titanita) negativo entre - 3,0 e - 4,5. O hornblenda-gnaisse encaixante exibiu $\varepsilon N d(T=820 \mathrm{Ma}$, idade da unidade ortognáissica Sanclerlândia - Motta de Araújo, 2012) de -5,6, resultados comparáveis aos obtidos nas unidades ortognáissicas e supracrustais que compõem AMA (Fig. 17). Os valores de $\varepsilon N d$ das rochas da SSLMB são distintos dos corpos máfico-ultramáficos do AMA (Fig. 17 e Tabela 1), com valores negativos, sugerindo magmatismo derivado de uma fonte levemente empobrecida em elementos radiogênicas para rochas ultramáficas da SSLMB. Não foi possível determinar os valores de TDM para as rochas analisadas. 
Tabela 9 - Dados geocronológicos de U-Pb em cristais de titanita. Para o cálculo das razões foram utilizados o padrão GJ1.

\begin{tabular}{|c|c|c|c|c|c|c|c|c|c|c|c|c|c|c|c|c|c|c|}
\hline \multirow[b]{2}{*}{ Sample } & \multirow[b]{2}{*}{$f(206)$} & \multicolumn{9}{|c|}{ Atomic ratios and erros } & \multicolumn{6}{|c|}{ Model Ages and errors } & \multicolumn{2}{|c|}{$\begin{array}{l}\text { Relationship between two rations } \\
\text { Conc }(\%)\end{array}$} \\
\hline & & ${ }^{206} \mathrm{~Pb} /{ }^{204} \mathrm{~Pb}$ & $\pm 1 \mathrm{~s}$ & ${ }^{207} \mathrm{~Pb} /{ }^{206} \mathrm{~Pb}$ & $\pm 1 \mathrm{~s}$ & ${ }^{206} \mathrm{~Pb} /{ }^{238} \mathrm{U}$ & $\pm 1 \mathrm{~s}$ & ${ }^{207} \mathrm{~Pb} /{ }^{235} \mathrm{U}$ & $\pm 1 \mathrm{~s}$ & Rho & ${ }^{207} \mathrm{~Pb} /{ }^{206} \mathrm{~Pb}$ & $\pm 1 \mathrm{~s}$ & ${ }^{206} \mathrm{~Pb} /{ }^{238} \mathrm{U}$ & $\pm 1 \mathrm{~s}$ & ${ }^{207} \mathrm{~Pb} /{ }^{235} \mathrm{U}$ & $\pm 1 \mathrm{~s}$ & $\begin{array}{l}\left({ }^{206} \mathrm{~Pb} / /^{238} \mathrm{U}\right)- \\
\left({ }^{207} \mathrm{~Pb} /{ }^{206} \mathrm{~Pb}\right)\end{array}$ & $\begin{array}{l}\left({ }^{206} \mathrm{~Pb} / /^{238} \mathrm{U}\right)- \\
\left({ }^{207} \mathrm{~Pb} /{ }^{235} \mathrm{PbU}\right)\end{array}$ \\
\hline 004-TN1 & 0.096 & 80.556 & 2.428 & 0.219 & 0.004 & 0.115 & 0.002 & 3.485 & 0.081 & 0.596 & 2976 & 29 & 703 & 9 & 1524 & 18 & 76 & 54 \\
\hline $005-\mathrm{TN} 2$ & 0.184 & 77.568 & 1.144 & 0.294 & 0.002 & 0.135 & 0.001 & 5.466 & 0.068 & 0.678 & 3438 & 13 & 816 & 6 & 1895 & 11 & 76 & 57 \\
\hline 006-TN3 & 0.277 & 114.988 & 1.572 & 0.210 & 0.004 & 0.108 & 0.002 & 3.121 & 0.083 & 0.686 & 2903 & 30 & 661 & 11 & 1438 & 20 & 77 & 54 \\
\hline 007-TN4 & 0.364 & 77.256 & 1.260 & 0.226 & 0.006 & 0.116 & 0.004 & 3.611 & 0.155 & 0.777 & 3022 & 42 & 708 & 22 & 1552 & 34 & 77 & 54 \\
\hline 009-TN6 & 0.564 & 109.530 & 1.871 & 0.217 & 0.003 & 0.119 & 0.001 & 3.573 & 0.071 & 0.592 & 2960 & 25 & 727 & 8 & 1544 & 16 & 75 & 53 \\
\hline 010-TN7 & 0.664 & 138.527 & 1.227 & 0.176 & 0.002 & 0.108 & 0.001 & 2.632 & 0.047 & 0.751 & 2616 & 19 & 663 & 8 & 1310 & 13 & 75 & 49 \\
\hline 011-TN8 & 0.752 & 76.689 & 0.928 & 0.258 & 0.004 & 0.126 & 0.002 & 4.469 & 0.104 & 0.639 & 3234 & 27 & 763 & 11 & 1725 & 19 & 76 & 56 \\
\hline 015-TN9 & 0.089 & 73.865 & 1.673 & 0.345 & 0.006 & 0.155 & 0.002 & 7.390 & 0.158 & 0.581 & 3684 & 26 & 932 & 11 & 2160 & 19 & 75 & 57 \\
\hline 016-TN10 & 0.177 & 106.596 & 1.284 & 0.210 & 0.003 & 0.112 & 0.002 & 3.227 & 0.074 & 0.765 & 2903 & 23 & 682 & 11 & 1464 & 18 & 77 & 53 \\
\hline 017-TN11 & 0.268 & 55.896 & 0.582 & 0.366 & 0.004 & 0.147 & 0.002 & 7.420 & 0.124 & 0.687 & 3775 & 17 & 884 & 9 & 2163 & 15 & 77 & 59 \\
\hline 018-TN12 & 0.364 & 73.586 & 1.320 & 0.323 & 0.007 & 0.153 & 0.004 & 6.812 & 0.236 & 0.783 & 3584 & 32 & 918 & 23 & 2087 & 30 & 74 & 56 \\
\hline 020-TN14 & 0.554 & 88.966 & 1.273 & 0.229 & 0.004 & 0.119 & 0.001 & 3.747 & 0.078 & 0.568 & 3044 & 27 & 723 & 8 & 1582 & 17 & 76 & 54 \\
\hline 021-TN15 & 0.665 & 56.957 & 1.500 & 0.439 & 0.008 & 0.177 & 0.003 & 10.730 & 0.295 & 0.715 & 4049 & 28 & 1051 & 19 & 2500 & 25 & 74 & 58 \\
\hline 026-TN17 & 0.090 & 110.720 & 1.931 & 0.225 & 0.003 & 0.111 & 0.002 & 3.434 & 0.067 & 0.777 & 3015 & 19 & 677 & 10 & 1512 & 15 & 78 & 55 \\
\hline 028-TN19 & 0.287 & 107.284 & 1.160 & 0.218 & 0.002 & 0.117 & 0.001 & 3.523 & 0.057 & 0.722 & 2966 & 17 & 714 & 8 & 1532 & 13 & 76 & 53 \\
\hline $029-\mathrm{TN} 20$ & 0.385 & 129.297 & 1.517 & 0.191 & 0.002 & 0.111 & 0.001 & 2.912 & 0.049 & 0.752 & 2747 & 17 & 677 & 8 & 1385 & 13 & 75 & 51 \\
\hline $033-\mathrm{TN} 24$ & 0.746 & 81.553 & 1.998 & 0.214 & 0.005 & 0.118 & 0.002 & 3.499 & 0.097 & 0.597 & 2939 & 35 & 721 & 11 & 1527 & 22 & 75 & 53 \\
\hline 038-TN26 & 0.184 & 132.382 & 2.077 & 0.183 & 0.004 & 0.110 & 0.002 & 2.770 & 0.073 & 0.662 & 2682 & 32 & 671 & 11 & 1348 & 20 & 75 & 50 \\
\hline $039-\mathrm{TN} 27$ & 0.272 & 73.970 & 1.206 & 0.312 & 0.005 & 0.142 & 0.002 & 6.094 & 0.130 & 0.698 & 3529 & 23 & 855 & 12 & 1989 & 18 & 76 & 57 \\
\hline $040-\mathrm{TN} 28$ & 0.366 & 53.326 & 0.864 & 0.358 & 0.009 & 0.154 & 0.005 & 7.584 & 0.311 & 0.760 & 3742 & 40 & 921 & 27 & 2183 & 36 & 75 & 58 \\
\hline 043-TN31 & 0.653 & 68.202 & 0.982 & 0.329 & 0.005 & 0.138 & 0.002 & 6.251 & 0.132 & 0.732 & 3612 & 21 & 832 & 12 & 2012 & 18 & 77 & 59 \\
\hline
\end{tabular}




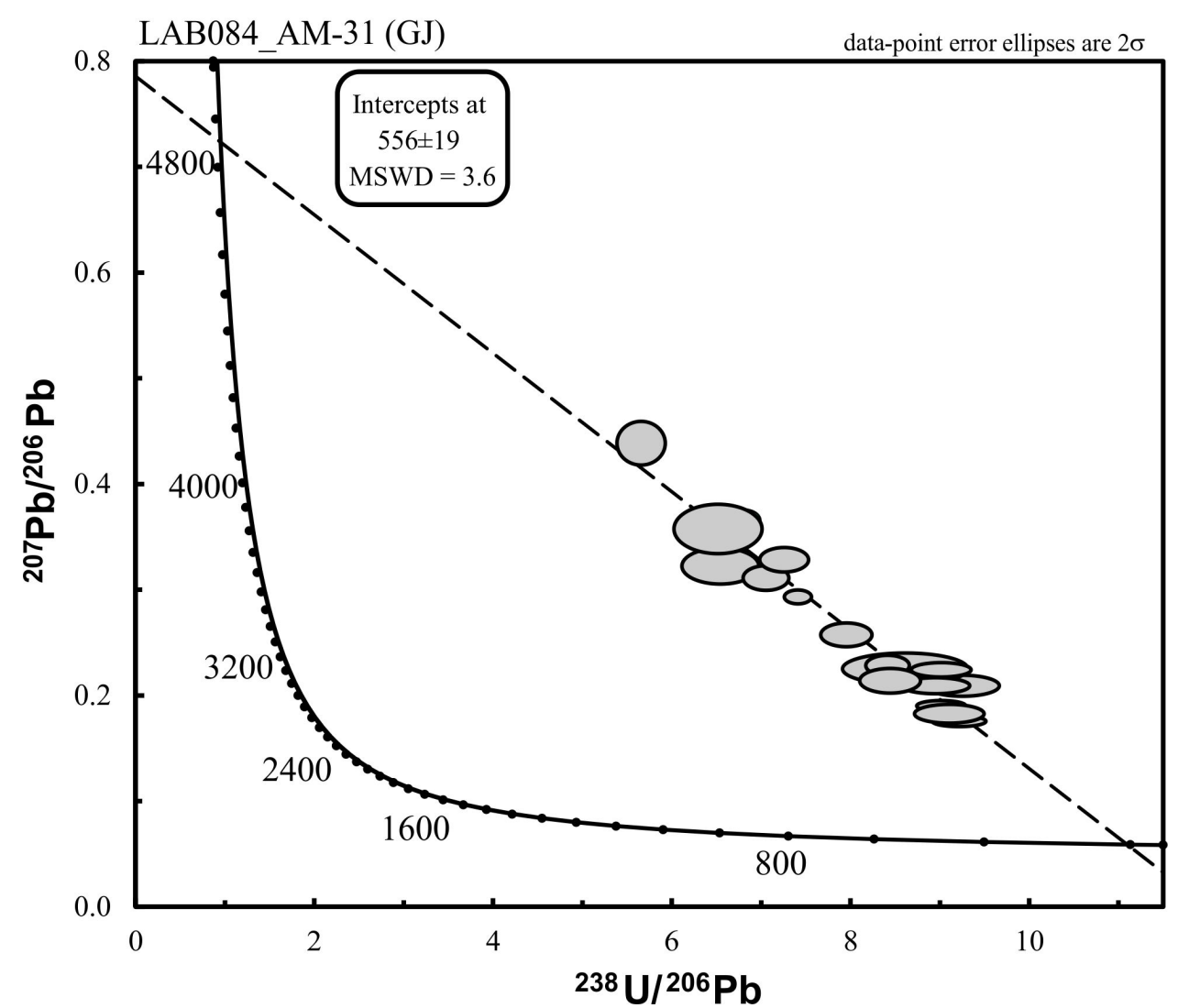

Figura 16 - Diagrama U-Pb Tera-Wasserburg (1972) dos grãos de titanita da amostra Am 31. O intercepto inferior corresponde à idade do hidrotermalismo, enquanto que o intercepto superior de não tem significado geológico.

\section{Discussão}

\subsection{Formação da Vermiculita}

A presença de hidroflogopita tanto em piroxenitos e em peridotitos (Figs. 5C e 6B) são evidências de que a vermiculita é originada a partir de lamelas de flogopita. Segundo Hindman (1992), o processo de transformação da flogopita para vermiculita é gradual e envolve a perda do íon potássio. Tal processo pode ser observado na análise de uma lamela pertencente ao peridotito da amostra FS 101 (Fig. 6B e 18), onde uma extremidade possui concentração de 9,49\% de $\mathrm{K}_{2} \mathrm{O}$ (análise FS-101-III CIV_3 - Tabela 3), outra extremidade possui concentração de 1,52\% de $\mathrm{K}_{2} \mathrm{O}$ (análise FS-101-III CIV_1 - Tabela 7) e um ponto intermediário acusou concentração de 6,62 \% $\mathrm{K}_{2} \mathrm{O}$ (análise FS101-III CIV_2 - Tabela 7). Além do decréscimo da concentração de $\mathrm{K}_{2} \mathrm{O}$ de uma extremidade para outra, nesse interestratificado, também se observa um comportamento inverso para $\mathrm{MgO}$ e $\mathrm{H}_{2} \mathrm{O}$ (Fig. 18), evidenciando a formação da vermiculita a partir da flogopita. 
Tabela 10 - Dados de Sm-Nd das rochas da SSLMB e encaixante

\begin{tabular}{|c|c|c|c|c|c|c|c|c|c|c|c|}
\hline Sample & Lithotype & $\mathrm{Sm}(\mathrm{ppm})$ & $\mathrm{Nd}(\mathrm{ppm})$ & $\mathrm{Sm} / \mathrm{Nd}$ & ${ }^{147} \mathrm{Sm} /{ }^{144} \mathrm{Nd}$ & ${ }^{143} \mathrm{Nd} /{ }^{144} \mathrm{Nd}$ & $\pm 2 \mathrm{SE}$ & $\left({ }^{143} \mathrm{Nd} /{ }^{144} \mathrm{Nd}\right)_{0}$ & $\varepsilon_{\mathrm{Nd}(0)}$ & $\varepsilon_{\mathrm{Nd}(\mathrm{T})}$ & $\mathrm{T}_{\mathrm{DM}}(\mathrm{Ga})$ \\
\hline Am20 & Hornblendite I & 17.42 & 79.87 & 0.2181 & 0.1318 & 0.512248 & 3 & 0.512248 & -7.6 & -3.0 & - \\
\hline AM27 & Hornblendite II & 3.97 & 12.53 & 0.3169 & 0.1916 & 0.512430 & 9 & 0.512429 & -4.1 & - & - \\
\hline FS33 $3_{\text {Bottom }}$ & Hornblendite I & 12.14 & 50.45 & 0.2763 & 0.1454 & 0.512221 & 17 & 0.512242 & -8.1 & -4.5 & - \\
\hline FS33 & Vrm-phlogopitite & 1.88 & 6.81 & 0.2405 & 0.1671 & 0.512243 & 7 & 0.512220 & -7.7 & -5.6 & - \\
\hline $123-90,92$ & Clinopyroxenite & 4.667 & 19.828 & 0.2618 & 0.1423 & 0.51225 & 5 & 0.512208 & -7.57 & -3.4 & - \\
\hline $123-99,6$ & Clinopyroxenite & 3.051 & 10.862 & 0.3834 & 0.1698 & 0.512335 & 10 & 0.512276 & -5.92 & -3.8 & - \\
\hline $\begin{array}{c}123- \\
100.19\end{array}$ & Clinopyroxenite & 4.098 & 10.688 & 0.2809 & 0.2318 & 0.512277 & 21 & 0.512334 & -7.05 & - & - \\
\hline FS101 & Peridotite & 0.959 & 3.663 & 0.3058 & 0.1582 & 0.512209 & 30 & 0.512230 & -8.38 & -5.4 & - \\
\hline $123-93,95$ & Peridotite & 1.08 & 3.532 & 0.2354 & 0.1849 & 0.512231 & 15 & 0.512249 & -7.94 & - & - \\
\hline Am159 & Ortogneiss & 4.86 & 22.82 & 0.2131 & 0.1288 & 0.512558 & 6 & 0.512557 & -1.6 & 5.6 & - \\
\hline
\end{tabular}

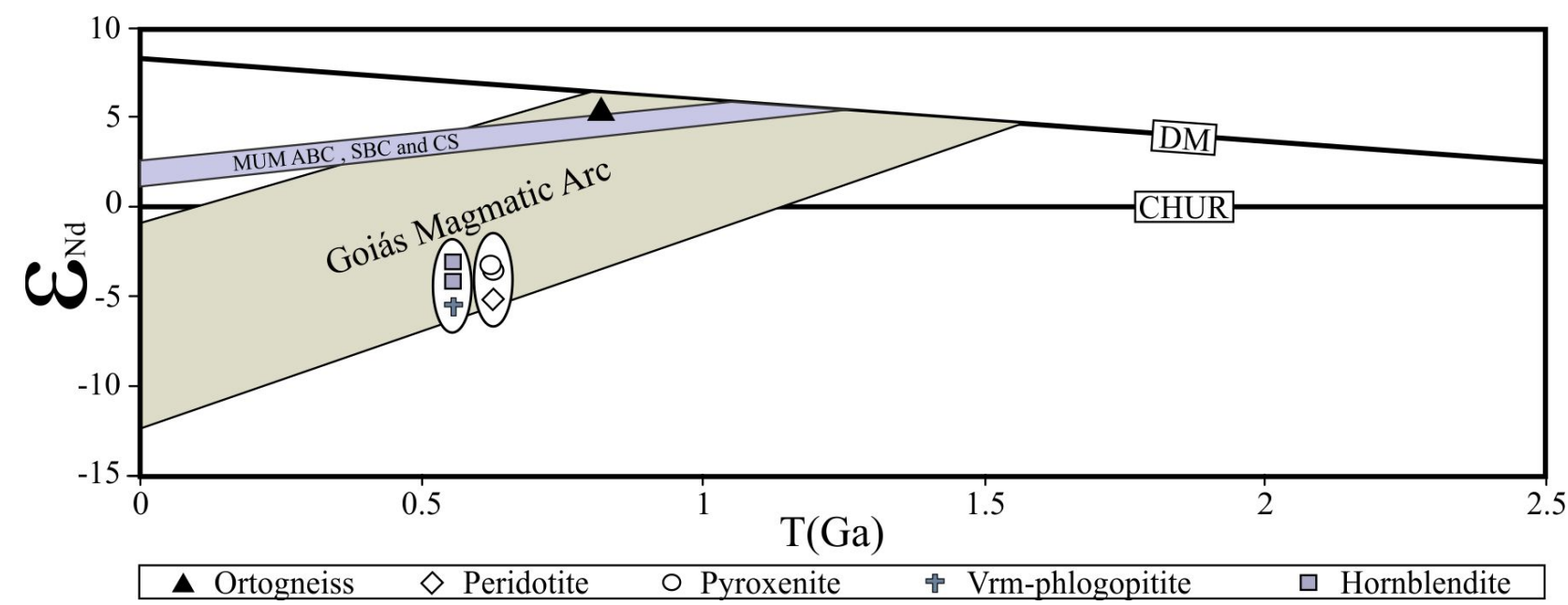

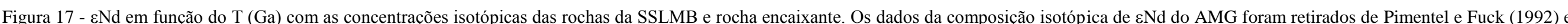

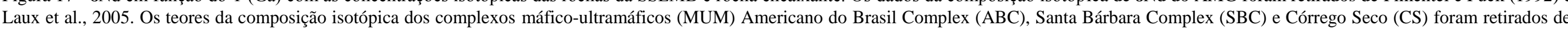
Gioia, (1997), Nilson et al., (1997) e Laux et al., (2004). 
Diversos estudos (Bassett 1959; 1963, De la Calle e Suquet 1988; Hindman 1992; Roy e Romo 1957; dentre outros), discutem sobre o processo de formação da vermiculita ser formada por hidrotermalismo ou durante o intemperismo. Porém, é de comum acordo na literatura de que quando há ocorrência do interestratificado de vermiculita/mica, o processo de formação ocorre predominantemente durante o intemperismo. Em estudos realizados em laboratório, Bassett (1959) provou que flogopita altera para vermiculita em solução aquosa com 0,001 molar de magnésio em temperatura ambiente, mas em fluidos com concentrações com uma pequena concentração de potássio não formam vermiculita. Kalinowski e Schweda (2007), observaram que o processo de vermiculitização ocorre em soluções de baixo $\mathrm{pH}(\geq 3)$.

Embora, as lamelas de vermiculitas sejam geradas principalmente durante o intemperismo, alguns estudos sugerem que o processo de "vermiculitização" das micas inicia durante o hidrotermalismo (metassomatismo), em temperaturas entre $480^{\circ} \mathrm{C}$ e $200^{\circ} \mathrm{C}$ (Boettcher, 1966; Justo et al.,1987; Roy e Romo, 1957). Portanto, propõe-se que o processo de vermiculitização das lamelas de flogopita dos peridotitos da SSLMB iniciou no final dos processos hidrotermais sob condições de baixo $\mathrm{pH}$ e em soluções de baixa concentração de $\mathrm{K}^{+}$, evidenciado por flogopita sageníticas alterando para vermiculita (Figs. 5C, 6B e 18).

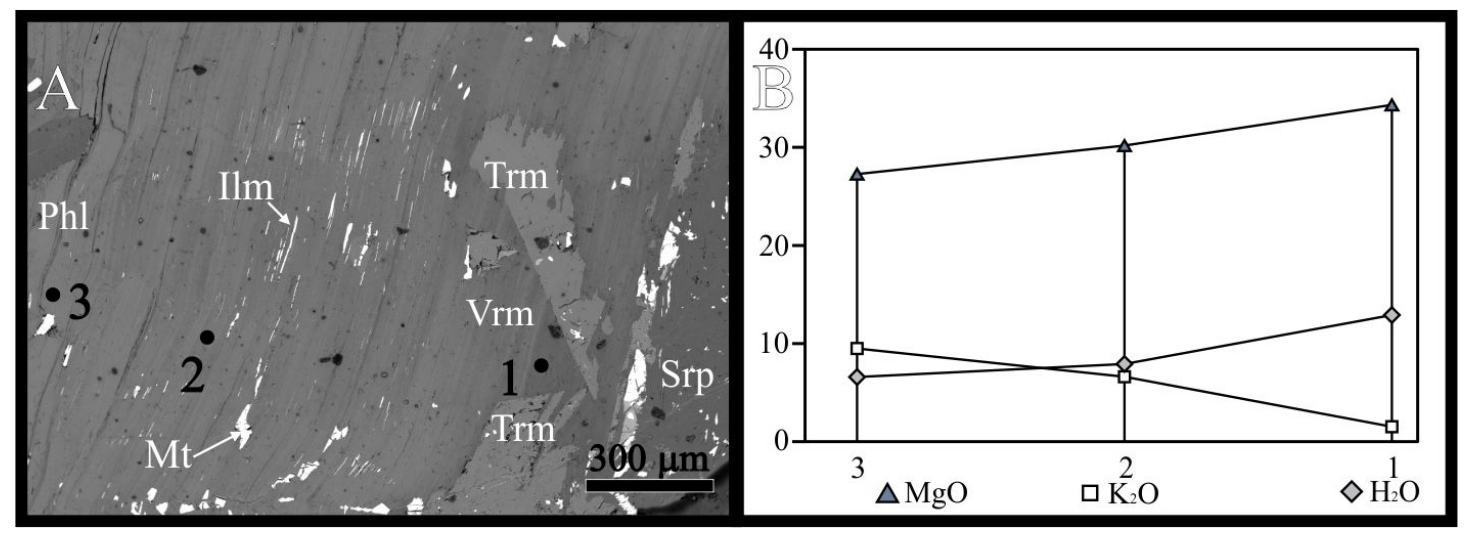

Figura 18 - A) Imagem BSE de detalhe da figura $6 \mathrm{C}$ com flogopita alterando para vermiculita e exsolução de ilmenita. B) Relação dos valores de $\mathrm{MgO}, \mathrm{K}_{2} \mathrm{O}$ e $\mathrm{H}_{2} \mathrm{O}$ dos pontos das figuras $6 \mathrm{C}$ e $18 \mathrm{~A}$.

\subsection{Processos de formação da SSLMB.}

Os corpos MPN, MPS, MPL e Leonel são acamadados, com camadas de peridotitos ou srp-mt-vrm - flogopitito sotopostas por clinopiroxenito ou vrm flogopitito (Fig. 19). Forsterita (Fo), diopsídio (Di) e flogopita com alto teor de titânio ( $\mathrm{T}$ - phl) representam a assembléia ígnea dos peridotitos com sequência de cristalização 
constituída por $\mathrm{Fo}>\mathrm{Di}>\mathrm{T}$ - Phl (Fig 20). A paragênese ígnea das camadas de clinopiroxenito está bem alterada, embora em algumas porções possa ser identificado que a formação de flogopita primária e diopsídio são concomitantes (Fig. 20). A etapa pós-magmática é evidenciada pelo processo da exsolução de agulhas de ilmenita de Tphl, formando flogopita sagenítica (S Phl) empobrecida em titânio (Shau et al., 1991).

Em algumas porções entre as camadas de peridotito e clinopiroxenito, há ocorrência de ovoides de: (i) olivina com corona de serpentina; (ii) tremolita com corona de talco; (iii) e Silva (2006), encontrou em outro corpo pertencente à SSLMB, ovoides compostos por núcleo de opx (clinoenstatita) e cpx com borda de talco ou serpentina. A ocorrência dos ovoides pode ser evidência de fusão incongruente envolvendo olivina e piroxênio, com partes submetidas a alteração hidrotermal para formação de tremolita, talco e serpentina. Também podem ser resultado da migração de fragmentos do peridotito ou piroxenito cumulado ainda na fase de "crystal mush" em um sistema de alta pressão de água, com vários episódios explosivos (Silva, 2006). O presente artigo não tem como objetivo caracterizar esse tipo de ocorrência.

Posterior à formação das camadas de peridotitos e clinopiroxenito, houve percolação de fluidos hidrotermais de natureza magmática por zonas de fraqueza gerando diques e veios quartzo - feldspáticos e hornblendito (Fig. 19). Os feldspatos dos diques e veios félsicos possuem composição alcalina, com predominância de albita $\left(\mathrm{Ab}_{90}\right)$ em relação à sanidina $\left(\mathrm{Or}_{83}\right)$. Em algumas porções, há ocorrência de pertita, evidenciando a formação primária de um feldspato potássico, com exsolução de plagioclásio sódico durante o resfriamento. Bordas de reação (Figs. 4E, 4F e 19) e veios de antofilita são formados pela interação do material félsico com a encaixante anteriormente ao resfriamento significativo dos fluidos, antes da cristalização dos diques e veios.

Os fluidos que formaram os diques e veios félsicos contribuíram para a introdução de água, potássio, silício e $\mathrm{CO}_{2}$ em peridotitos, para a formação de flogopita, antofilita, serpentina, magnetita, magnesita, vermiculita e calcita. Anfibólios ortorrômbicos magnesianos com teores de $\mathrm{Si}$ entre 7,7 e 8,05 e de $\mathrm{Na}$ e $\mathrm{Al}^{\mathrm{VI}}$ menores que 0,2 são comuns nos domínios de contato entre fluidos enriquecidos em sílica e peridotitos, pois a interação desses fluidos com olivina dificulta a formação de silicatos de cadeia ampla com maior conteúdo de sílica (Evans, 1982). A temperatura de formação da antofilita em sistemas isentos de ferro é estimada entre $650^{\circ} \mathrm{C}\left(\mathrm{pH}_{2} \mathrm{O}=\right.$ 
$2 \mathrm{Kbar})$ e $630^{\circ} \mathrm{C}\left(\mathrm{pH}_{2} \mathrm{O}=1 \mathrm{Kbar}\right)$, porém em sistemas com ferro se forma em temperaturas $\leq 600^{\circ} \mathrm{C}$ (Chernosky et al., 1985). A flogopita neoformada é evidenciada por ocorrência de lamelas de flogopita zonadas com núcleo composto por agulhas de ilmenita (sageníticas) e extremidades sem inclusões (Fig 5B). Tanto o núcleo quanto a extremidade possuem composições químicas semelhantes e ambas pertencem à população I (vide tópico 6). Vermiculita começou a se formar em temperaturas entre $480^{\circ} \mathrm{C}$ e $200^{\circ} \mathrm{C}$ (vide tópico 10.3 ), porém foram formadas principalmente durante o intemperismo. A formação de serpentina e magnetita a partir de olivina ocorre em temperaturas variando de $430^{\circ} \mathrm{C}\left(\mathrm{pH}_{2} \mathrm{O}=6,5 \mathrm{Kbar}\right)$ e $350^{\circ} \mathrm{C}\left(\mathrm{pH}_{2} \mathrm{O}=0,5 \mathrm{Kbar}\right)$ (Johannes, 1968), porém esses minerais podem ter continuado a se formar durante o intemperismo. A calcita ocorre apenas como cristais intersticiais.

A percolação dos fluidos que cristalizaram diques e veios félsicos contribuíram com água, potássio e $\mathrm{CO}_{2}$ no piroxenito, possibilitando a cristalização de actinolitatremolita, flogopita II, titanita, e calcita. Cristais de clinopiroxênio com concetrações baixas de $\mathrm{Cr}_{2} \mathrm{O}_{3}$ e $\mathrm{TiO}_{2}$ são predominates, embora ocorram valores significantes em alguns cristais (vide tópico 6.4). A lixiviação de $\mathrm{Ti}$ e $\mathrm{Cr}$ dos cristais ígneos (piroxênio ou flogopita) e o alumínio e silício disponibilizados no sistema proporcionaram a formação de cristais de titanita (Figs 5D e 5E e tópico 6.6). Em sistemas com elevada concentração de alumínio a titanita pode se formar em temperaturas entre $300^{\circ} \mathrm{C}$ e $400^{\circ} \mathrm{C}$ (Enami, 1993) (vide tópico 8). A flogopita pode se formar em temperaturas entre $400^{\circ} \mathrm{C}$ e $900^{\circ} \mathrm{C}$ (Wones, 1965), porém nesse sistema a flogopita tipo II (tópico 6.3) começou a se cristalizar juntamente com os cristais de titanita (Fig. 20). As lamelas de flogopita primária do clinopiroxenito foram reequilibradas, pois estas não se diferenciam quimicamente das lamelas tipo II. A entrada do $\mathrm{CO}_{2}$ é evidenciada por calcita preenchendo veios e como cristais dissociados.

Para a formação de flogopita a partir de clinopiroxênio é necessário uma grande concentração de alumínio, principalmente em um sistema com grande concentração de flogopita hidrotermal como as rochas da SSLMB. O alumínio pode ter sido adicionado ao sistema a partir dos fluidos hidrotermais, porém pouco provável, pois o alumínio é um elemento praticamente imóvel (Grant et al., 1986; 2003; Middelburg et al., 1988; e referências contidas nesses artigos). Assim, nós propomos que processos que afetaram os corpos da SSLMB propiciaram a lixiviação de alguns elementos das rochas, concentrando elementos como o alumínio. 
stage I

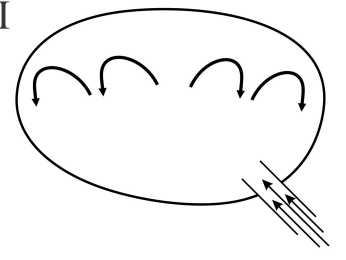

Influx of primitive magma forms the basa peridotite layer stage II

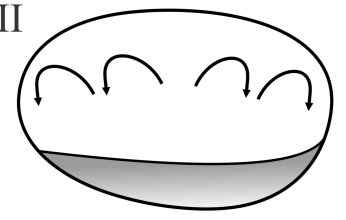

stage III

stage IV
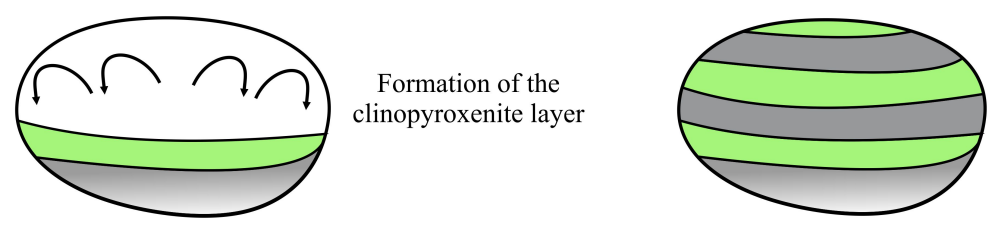

The layered formation

is continuous until magmatic activity in the chamber is ceased

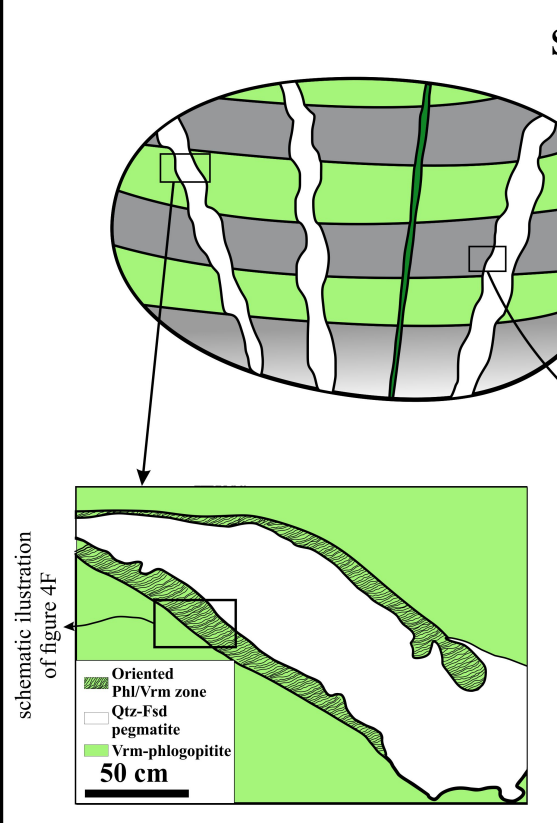

stage $\mathrm{V}$

The influx of hydrothermal fluids in which contributes with elements and then crystallize to quartz-feldspar dykes and veins and also the intrusion of ultramafic dykes rich in hornblende.

Figura 19 - Evolução esquemática dos corpos da SSLMB e ação dos fluidos magmático - hidrotermais. Abreviação mineral segundo Whitney e Evans (2010).

\subsection{SSLMB}

Embora os processos hidrotermais tenham afetado intensamente a SSLMB, ocorrem zonas menos alteradas com paragênese ígnea preservada, constituída por olivina, clinopiroxênio e flogopita. A sequência de cristalização ígnea é de $\mathrm{Ol}>\mathrm{Ol}+\mathrm{Cpx}$ $>\mathrm{Ol}+\mathrm{Cpx}+\mathrm{Phl}>\mathrm{Cpx}+\mathrm{Phl}$, determinada por petrografia. Rochas desprovidas de opx são derivadas de um magma subsaturado em $\mathrm{SiO}_{2}$ (Campbell, 1985). Os peridotitos são compostos por cerca de $30 \%$ de lamelas de flogopita sagenítica e segundo Shau et al., 
(1991) estas lamelas são secundárias, formadas a partir do processo sub-solidus em que há a ex-solução das agulhas de ilmenita de uma flogopita primária com concentração de titânio mais elevada.

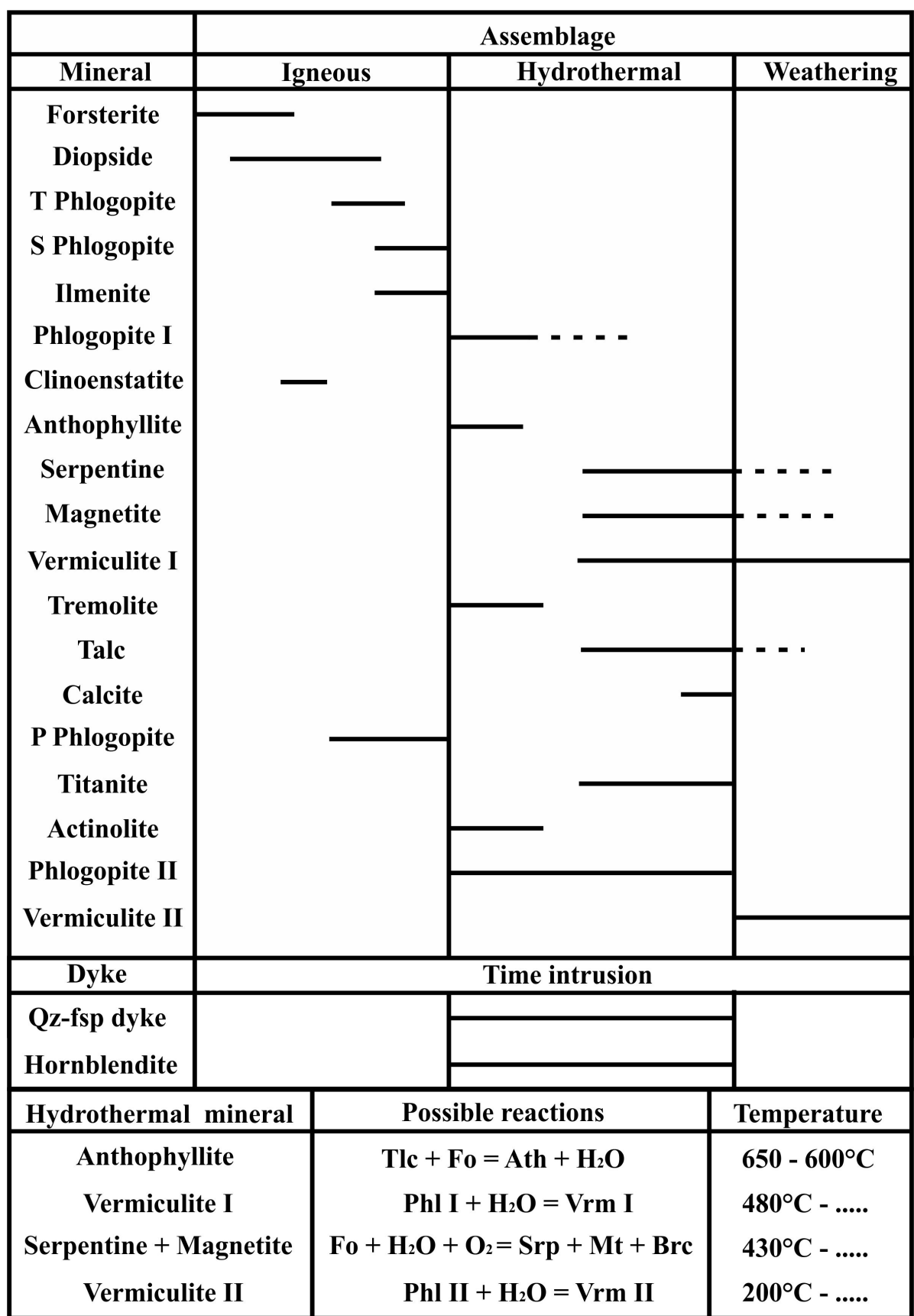

Figura 20 - Tabela com as assembleias paragenéticas de cada estágio da SSLMB, tempo de intrusões dos diques e possíveis reações de transformação para alguns minerais formados durante o hidrotermalismo e intemperismo.

A composição dos cristais de olivina $\left(\mathrm{Fo}_{83.29}\right.$ - 87.18) nos peridotitos da SSLMB são típicos de magma parental primitivo, com composição mais primitiva próxima ao reportado em peridotitos do $\mathrm{ABC}$ (Fo88; Nilson et al., 1981), Injibara, Etiópia (Fo89; Frezzotti et al., 2010), de Yancey County, EUA (Fo 86 ; Kulp e Brobst, 1954), e bebedouritos da Província Alcalina Alto Parnaíba (PIAP) Salitre, Brasil (Fo 7 ; Barbosa 
et al., 2012). Os peridotitos e clinopiroxenitos possuem elevada concentração de elementos compatíveis, com teores de níquel de 2113 ppm nas rochas menos evoluídas, e elevada concentração de ETR e LILE. Os elementos ETR normalizados ao condrito definiram perfis com ETRL enriquecidos em relação à ETRP e anomalias negativas de $\mathrm{Nb}$, Ta e Hf (vide tópico 7). Dados isotópicos de Sm-Nd para as rochas da SSLMB resultaram em valores negativos $(-3$ a $-5,6)$ para $\varepsilon N d(556$ - $604 \mathrm{Ma})$. O perfil fracionado dos ETR e os valores de $\varepsilon N d$ sugerem (i) contaminação crustal durante a ascenção e alojamento do magmatismo que gerou os corpos da suíte em níveis crustais mais rasos; ou (2) são características de um magmatismo derivado do manto metassomatizado. A ausência de ortopiroxênio cumulático e o elevado conteúdo de níquel em cristais de olivina são indicativos de sistemas magmáticos substaurado em sílica e sem segregação de sulfetos, respectivamente. Tais características permitem inferir que não houve contaminação de sílica e enxofre por material crustal, mas acrecionado as informações de ETR e $\varepsilon N d$ corroboram para que as rochas da SSLMB tenham sido formadas a partir do manto metassomatizado.

Rochas ultramáficas que possuem elevada concentração de elementos compatíveis e incompatíveis são derivadas do manto litosférico subcontinental metassomatizado (Winter, 2013), e anomalias negativas de $\mathrm{Nb}$, Ta e Hf são características de rochas formadas em ambiente de arco (Zhou et al., 2004). Os dados de geoquímica e isótopos de $\mathrm{Sm}-\mathrm{Nd}$ possibilitam aos autores do presente trabalho interpretar que as rochas da SSLMB foram formadas a partir do manto metassomatizado em ambiente de arco.

\subsection{SSLMB e outras ocorrências}

A SSLMB faz parte do conjunto de intrusões máfico-ultramáficas que ocorrem no AMA (Fig 2B). A maioria desses corpos foi identificada por anomalias geofísicas, porém poucos são estudados em detalhe, como o ABC (Mota e Silva et al., 2011, Nilson et. al. 1986), Mangabal (Candia, 1983) e Santa Bárbara (Silva, 1991). Os corpos máfico-ultramáficos até então estudados estão metamorfizados em fácies xisto-verde alto a anfibolito, com idades entre 626 e 598 Ma (Tabela 1) e sua gênese está associada ao final da colisão no setor meridional da Faixa Brasília entre 610 e 604 Ma (Junges et 
al., 2002; Pimentel et al., 2001). As rochas da SSLMB foram afetadas por hidrotermalismo, mas não foram pelos processos orogênicos que influenciaram os demais complexos máfico - ultramáficos acoplados ao AMA durante a colisão da Faixa Brasília, pois os peridotitos e clinopiroxenitos são desprovidos do metamorfismo regional (fácies anfibolito). Portanto, nós propomos que essas rochas se alojaram ao AMA após a colisão final da Faixa Brasília.

Além da ausência do metamorfismo típico dos corpos máfico-ultramáficos intrudidos durante o processo de colisão no AMA, a SSLMB possui outras características que a distinguem das demais intrusões acamadadas. Peridotitos e piroxenitos pertencentes ao $\mathrm{ABC}$, derivado de um magmatismo oriundo do manto depletado (Mota e Silva et al., 2011 e Nilson et al., 1986), apresentam perfil de ETR normalizado ao condrito com depleção de ETRL em relação ao ETRP, enquanto que no perfil das rochas da SSLMB, os ETRL são favorecidos (Fig. 14). O perfil dos elementos LILE para as rochas da SSLMB também são distintos do ABC, com tendência positiva para os elementos móveis. Os demais elementos incompatíveis possuem comportamentos semelhantes, embora com anomalias negativas de $\mathrm{Ta}, \mathrm{Nb}$ e $\mathrm{Hf}$ mais expressivas na SSLMB.

Outra diferença marcante das rochas da SSLMB em relação aos demais complexos máfico - ultramáficos do AMA é com relação ao $\varepsilon \mathrm{Nd}$. Os complexos Americano do Brasil, Santa Bárbara e Córrego Seco possuem valores positivos de $\varepsilon \mathrm{Nd}$ (T) positivo, enquanto que os peridotitos, piroxenitos, derivados hidrotermais e hornblenditos pertencentes à SSLMB possuem valores negativos (Fig. 17), indicando origem distinta da SSLMB dos demais complexos do AMA.

\subsection{Gênese da SSLMB}

As rochas da SSLMB possuem características estruturais, razões isotópicas de Sm-Nd e química de rocha distitntas aos complexos máfico - ultramáficos acoplado ao AMA durante a colisão final da Faixa Brasília (Fig. 21). As características das rochas da SSLMB também sugerem que estas são derivadas do manto metassomatizado, conforme mencionado no item 10.3. Tais informações adicionado a modelos sugeridos por outros autores para essa porção do AMA (Marques et al., 2016; Mota e Silva et al., 2011) e o 
modelo proposto por Soares (2006) para a porção norte do AMG, permitem inferir um modelo de evolução para a formação das rochas da SSLMB (Fig. 21).

O evento final da colisão na Faixa Brasília nessa porção envolve o processo de colisão entre com a subducção da placa de maior densidade (crosta oceânica) sob a placa de menor de menor densidade (crosta continental) e a formação de uma cadeia montanhosa (Fig. 21). A percolação de fluidos a partir de uma crosta oceânica subductada propiciou a hidratação e metassomatismo da cunha mantélica, permitindo a entrada de elementos móveis como o potássio. Após a colisão e fechamento da Faixa Brasília, no estágio de relaxamento do orógeno ocorre a fusão parcial da crosta metassomatizada, gerando o magmatismo que formou as rochas da SSLMB.

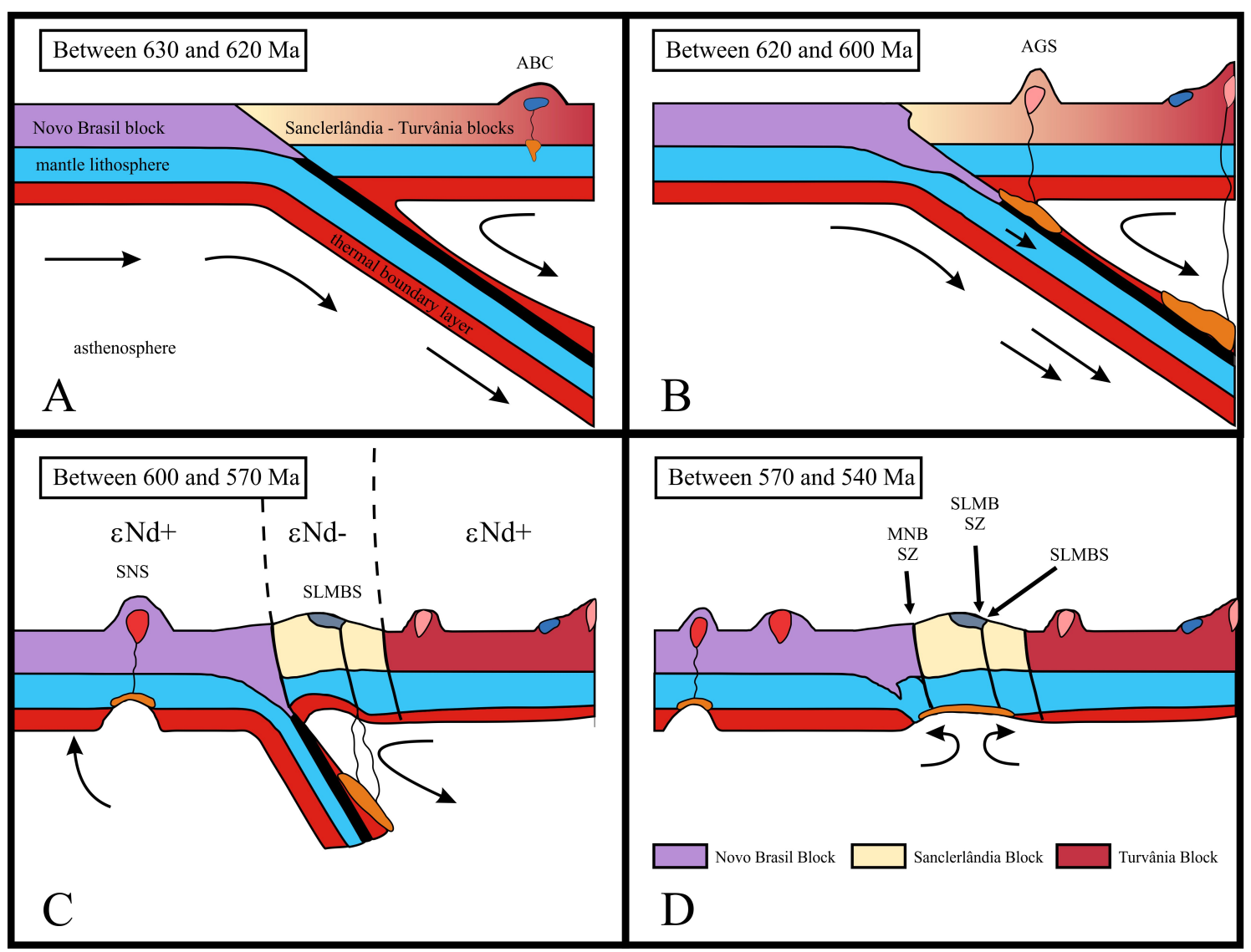

Figura 21 - A) e B) Colisão final e fechamento da Faixa Brasília, nessa porção da Faixa Brasília com formação do Complexo Americano do Brasil e os granitos da Suíte Aragoiânia. C) Hidratação e metassomatismo da cunha mantélica para formação da SSLMB no bloco Sanclerlândia e início da formação de granitoides no bloco Novo Brasil. Detalhe para as litologias dos blocos Novo Brasil e Turvânia possuíre $\varepsilon N d$ positivo e rochas do bloco Sanclerlândia possuírem $\varepsilon N d$ negativo. D) Extenção litosférica e interação do manto astenosférico e litosferérico gerando os fluidos para cristalizar hornblenditos, diques e veios quartzo-feldspáticos que intrudem a SSLMB. Modelo esquemático para formação dos corpos da SSLMB e intrusão dos diques félsicos e hornblenditos (modificado de Davies e von Blanckenburg, 1995) SLMBS = São Luís de Montes Belos Suite; AGS = Aragoiânia Suite; SNS = Serra Negra Suite; SLMB SZ= São Luís de Montes Belos Shear Zone; MNB SZ= Moiporá - Novo Brasil Shear Zone. 
Zonas ou falhas transcorrentes (strike-slip) são estruturas transcrustais ou translitosféricas que geralmente ocorrem em regimes tectônicos pós-colisionais e, associados a essas estruturas, ocorrem sistemas minerais magmáticos ou hidrotermais com elevado teor de potássio. Essas estruturas são capazes de alcançar profundidades litosféricas e se comportarem como condutos de material (Pirajno, 2010). Em sistemas afetados por processos hidrotermais, as zonas transcorrentes podem se comportar como condutos tanto para alojamento dos corpos ígneos quanto para entrada de fluidos meteóricos, magmáticos ou a mistura entre ambos que alteram as rochas (Pirajno, 2010). Os corpos MPN, MPS, MPL e Leonel ocorrem próximos à zc SLMB (Fig. 2) sugerindo magmatismo condicionado por esta estrutura, como ilustrado na figura $21 \mathrm{C}$. A geometria e estruturação desses corpos da SSLMB também são indícios de que a intrusão dos corpos está relacionada à estrutura transcrustal. Segundo Pirajno et al., (2010), intrusões sin-cinemáticas às zonas transcorrentes possuem geometria elipsoidal, e foliação paralela a estrutura, características que podem ser observadas nos corpos da SSLMB (Fig. 3). A deformação incipiente sugere que o alojamento foi no final do evento orogênico.

Nos blocos Uvá e Novo Brasil (vide tópico 3.4) ocorrem granitoides potássicos da SSN com idades entre 560 e 550 Ma (Marques et al., 2016), próximos as zonas transcorrentes relacionadas ao TBL e a zc MNB (Figs. 1 e 2). Segundo Marques et al., (2016), essas zonas de cisalhamento foram responsáveis pela extensão litosférica e se comportaram como condutos do material do manto astenosférico para o manto litosférico, permitindo fusão parcial da crosta continental inferior, o que gerou os granitos ultrapotássicos do tipo A da SSN. Um processo análogo pode ter ocorrido para a formação dos diques félsicos e hornblenditos, o qual o material do manto astenosférico ascendeu pela zc SLMB e interagiu com o manto litosférico produzindo fluidos com elevado teor de potássio que intrudiram a SSLMB (Fig 21 D).

\section{Conclusão}

As principais conclusões baseadas em estudos anteriores e em dados levantados nesse artigo estão listada as seguir: 
1 - Os corpos da SSLMB foram intensamente influenciados por hidrotermalismo e intemperismo. Porém, cristais reliquiares em zonas preservadas permitem inferir que as rochas da Suíte São Luís de Montes Belos são peridotitos e piroxenitos com sequência de cristalização definida por $\mathrm{Ol}>\mathrm{Ol}+\mathrm{Cpx}>\mathrm{Ol}+\mathrm{Cpx}+\mathrm{Phl}>$ $\mathrm{Cpx}+\mathrm{Phl}$. O teor de forsterita em olivina $\left(\mathrm{Fo}_{83.29}-87.18\right)$ sugere magmatismo parental primitivo para as rochas da SSLMB. A presença de flogopita como mineral ígneo reliquiar sugere magmatismo com elevado teor de potássio. A ausência de ortopiroxênio cumulático e grandes quantidades de sulfeto é indicativo de que não houve contaminação no magma;

2 - As características texturais e estruturais dos corpos da SSLMB sugerem um caráter pós-colisional em relação ao fechamento da Faixa Brasília e sin-cinemático à zona de cisalhamento São Luís de Montes Belos;

3 - As características geoquímicas das rochas da SSLMB são muito distintas de peridotitos e clinopiroxenitos do complexo Americano do Brasil. O perfil de ETR normalizado ao condrito definiu um perfil depletado em ETRP em relação aos ETRL. O perfil dos elementos incompatíveis móveis e imóveis normalizado ao condrito definiram enriquecimento de $\mathrm{K}, \mathrm{Rb}$ e $\mathrm{Ba}$ e anomalias negativas de $\mathrm{Ta}$, $\mathrm{Nb}$ e Hf;

4 - As rochas da SSLMB obtiveram $\varepsilon N d$ (T) negativo, tanto para os hornblenditos quanto para peridotitos e piroxenitos, resultados diferentes dos demais complexos máfico - ultramáficos que intrudem o AMA, sugerindo um contexto de formação diferente para as rochas da SSLMB;

5 - Os fluidos que cristalizaram diques e veios quartzo - feldspáticos são os principais responsáveis pelo hidrotermalismo nos corpos da SSLMB. A paragênese hidrotermal associada a vrm - flogopititos e srp-mt-vrm - flogopititos, identificada por estudos petrográficos detalhados é constituída por flogopita, titanita, antofilita, serpentina, magnetita, tremolita - actinolita, talco e calcita;

6 - As lamelas de vermiculita, que ocorrem em peridotitos, piroxenitos e na interface de reação entre diques quartzo-feldspáticos e encaixantes foram geradas a partir de flogopita. A vermiculita foi formada principalmente durante os processos de intemperismo, embora o processo de vermiculitização da flogopita dos peridotitos tenha iniciado na etapa final do hidrotermalismo.

7 - Datação U-Pb em titanita acusou idade de $556 \pm 19$ Ma do evento metassomático responsável pela formação de vermiculita I a partir de flogopita I; 
8 - A fonte magmática para a formação das rochas da SSLMB provavelmente foi derivada do manto metassomatizado, gerado em um ambiente de subducção (pós colisional ao fechamento da Faixa Brasília), envolvendo hidratação e metassomatismo da cunha mantélica, com ascenção desse magmatismo por meio da zc SLMB;

9 - Os fluidos hidrotermais responsáveis pela alteração das rochas da SSLMB podem ter sido gerados por fusão parcial da crosta continental inferior, desenvolvida a partir da interação do material do manto astenosférico.

10 - A Suíte São Luís de Montes Belos é a única suíte ultramáfica pós colisional de idade Neoproterozóica do Arco Magmático Arenópolis.

\section{Agradecimentos}

Os autores agradecem a Coordenação de Aperfeiçoamento de Pessoal de Nível Superior (Capes) pelo suporte ao projeto e a Brasil Minérios S.A. por conceder acesso à área e aos dados para realização do projeto e aos laboratórios de Microssonda Eletrônica e de Geocronologia do Instituto de Geociências da Universidade de Brasília.

\section{Referências}

Albarède, F., Télouk, P., Blichert-Toft, J., Boyet, M., Agranier, A., Nelson, B., 2004. Precise and accurate isotopic measurements using multiple-collector ICPMS. Geochim Cosmochim Acta. 68, 2725-2744.

Almeida, F. F. M. de, Hasui Y., Brito Neves B. B. de, Fuck R. A., 1977. As províncias estruturais brasileiras. In: SBG, Ata do Simpósio de Geologia NE, 8, Campina Grande, 1977., Campina Grande, 363-391. (In Portuguese).

Almeida F.F.M.de, Hasui Y., Brito Neves B.B.de, Fuck R. A. 1981. Brazilian structural provinces: an introduction. Earth-Science Reviews. 17,1-21.

Amin M. S., Afia M. S., 1954. Anthophyllite-Vermiculite Deposit of Hafafit, Eastern Desert, Egypt. Economic Geology. 49, 317-327.

Araújo Filho, J.O., 2000. The Pirineus syntaxis: an example of intersection of two Brasiliano fold thrust belts in Central Brazil, and its implications for the tectonic evolution of Western Gondwana. Revista Brasileira de. Geosciências. 30, 144-148.

Baêta, Jr. J.D., Moreton, L.C., 1999. Geologia. Programa Levantamentos Geológicos Básicos do Brasil. Sanclerlândia, Folha SE.22-X-A-II, Morro Agudo de Goiás, Folha SD.22-Z-C-II, Goiás, Folha SD.22-Z-C-V, Esca la 1:100.000. Estado de Goiás. 5, 11 - 59. (In Portuguese).

Baldwin, J.A., Powell, R., Brown, M., Moraes, R., Fuck, R.A., 2005. Modelling of mineral equilibra in ultrahigh-temperature metamorphic rocks from the Anápolis-Itauçu Complex, central Brazil. Journal of Metamorphic Geology. 23, 511-531.

Barbosa, E. S. R., Brod, J. A., Junqueira-Brod, T. C., Dantas, E. L., Cordeiro, P. F. de O., Gomide, C. S., 2012. Bebedourite from its type area (Salitre I complex): A key petrogenetic series in the LateCretaceous Alto Paranaíba kamafugite-carbonatite-phoscorite association, central Brazil. Lithos. 144-145, 56-72.

Bassett, W. A., 1959. Origin of the vermiculite deposit at Libby, Montana. The American Mineralogist. 44, 282-299.

Basset, W.A., 1963. The geology of vermiculite occurrences. Clays and Clay Minerals 10, 61-69.

Boettcher, A.L., 1966. Vermiculite, hydrobiotite, and biotite in the rainy creek igneous complex near Libby, Montana. Clay Minerals. 6, 283-296.

Borovikov, P.P., 1962. Genetic types, conditions of formation and economic evaluation of vermiculite deposits. In Perlite and Vermiculite (Geology, Russian. Centre.New Delhi: Indian National Scientific DocumentationTechnology.) Edited by V.Kh. Daragan. Translated from Exploration and Production. 139-176 
Bühn B, Pimentel MM, Matteini M, Dantas EL., 2009. High spatial resolution analysis of Pb and U isotopes for geochronology by laser ablation multi-collector inductively coupled plasma mass spectrometry (LA-MC-ICP-MS). Anais da Academia Brasileira de Ciências. 81,1,1-16.

Bush, A.L., 1976. Vermiculite in the United States. Montana Bureau of Mines and Geology. In: 11th Industrial Minerals Forum, Montana Bureau of Mines and Geology, Special Publication. 74, 146155.

Campbell, I. H., 1985. The difference between oceanic and continental tholeiites: a fluid dynamic explanation. Contribution to Mineralogy and Petrology. 91, 37-43.

Candia Fornoni M.A., 1983. Petrologia dos complexos mafico-ultramaficos de Mangabal I e Mangabal II, Sanclerlândia, Goiás. Unpublished PhD Thesis, Geoscience Institute from São Paulo University, 400 p.

Chernosky, J. V. Jr., Day, H. W, Caruso L. J., 1985. Equilibria in the system MgO-SiO2-H20: experimental determination of the stability of Mg-anthophyllite. American Minetalogist. 70, 223236.

Danni, J.C.M., Dardenne, M.A., Fuck, R.A., Ribeiro, M.J., 1973. Geologia da extremidade sudoeste de serra Dourada (Goias, Brasil). Revista Brasileira de Geociências. 3, 160-180. (In Portuguese).

De la Calle, C. e Suquet, H., 1988. Vermiculite. In: Hydrous Phyllosilicates. Reviews in Mineralogy. Mineralogical Society of America. 19, 455-496.

Deer W.A.; Howie R.A.; Zussman J. 1992. Vermiculite. In: An Introduction to the Rock Forming Minerals.2nd end Longman, Harlow, Essex. 377-381.

Delgado, I. M., Souza, J. D., Silva, L. C., Silveira Filho, N. C., Santos, R. A., Pedreira, A. J., Guimarães, J. T., Angelim, L. A. A., Vasconcelos, A. M., Gomes, I. P., Lacerda Filho, J. V., Valente, R. C., Perrota, M. M., E. Heineck, C. A., 2003. Geotectônica do Escudo Atlântico. In: Geologia, Tectônica e Recursos Minerais do Brasil (Bizzi, L. A.; Schobbenhaus, C.; Vidotti, R. M. \& Gonçalves, J. H., Eds.). CPRM, Brasília, Brasil, 227-334. (In Portuguese).

Della Giustina, M.E.S., 2007. Geologia e geocronologia da sequência vulcano-sedimentar Campinorte e do complexo Uruaçu, Província Tocantins. Unpublished M.S.c Thesis, Univesity of Brasília. 106p. (In Portuguese).

Della Giustina, M.E.S., Oliveira, C.G., Pimentel, M.M., Melo, L.V., Fuck, R.A., Dantas, E.L., Buhn, B., 2009. U-Pb and $\mathrm{Sm}-\mathrm{Nd}$ constraints on the nature of the Campinorte Sequence and related Paleoproterozoic juvenile orthogneisses, Tocantins Province, Central Brazil. Geological Society of London Special Publication 323, 255-269.

Della Giustina, M.E.S., Pimentel, M.M., Ferreira Filho, C.F., Fuck, R.A., Andrade, S., 2011a. U-Pb-Hftrace element systematics and geochronology of zircon from a granulite-facies metamorphosed mafic-ultramafic layered complex in Central Brazil.Precambrian Research. 189, 176- 192.

Della Giustina, M.E.S.; Pimentel,M.M.; Ferreira filho, C.F.; De Hollanda, M.H.B.M., 2011b. Dating coeval mafic magmatism and ultrahight temperature metamorphism in the Anápolis-Itauçu complex, Central Brazil. Lithos. 134, 82-102.

Enami, M., Suzuki, K., Liou, J.G., Bird, D.K., 1993. Al-Fe3 and F-OH substitutions in titanite and constraints on their P-T dependence. European Journal of Mineralagy. 5, 219-223.

Essex, R.M., Gromet, L.P., Andréasson, P.-G., Albrecht, L., 1997. Early Ordovician U-Pb metamorphic ages of the eclogite bearing, Seve Nappes, Northern Scandinavian Caledonides. Journal of Metamorphic. Geology. 15, 665-676.

Evans B. W., 1982. Amphiboles in ultramafic rocks. In Veblen D.R e Ribbe P. H. (eds). AMPHIBOLES: PETROLOGY and EXPERIMENTAL PHASE RELATIONS.98 - 113.

Ferreira Filho, C.F., de Moraes, R., Fawcett, J.J., Naldrett, A.J., 1998. Amphibolite to granulite progressive metamorphism in the Niquelândia Complex, Central Brazil: regional tectonic implications. Journal of South American Earth Sciences. 11, 35-50.

Föster, M.D., 1960. Interpretation of the Composition of Trioctahedral Mica. Geological Survey Professional Paper. 354-B, 11-49.

Frezzoti, M. L., Fernando, S., Peccerillo, A., Petrelli, M., Tecce, F., Perucchi, A., 2010 Chlorine-rich metasomatic $\mathrm{H} 2 \mathrm{O}-\mathrm{CO} 2$ fluids in amphibole-bearing peridotites from Injibara (Lake Tana region, Ethiopian plateau): Nature and evolution of volatiles in the mantle of a region of continental flood basalts. Geochimica et Cosmochimica Acta. 74, 3023-3039.

Frost, B.R.; Chamberlain, K.R.; Schumacher, J.C.; Scott, D.J.; Moser, D.E. 2000. Sphene (titanite): phase relations and role as a geochronometer. Chemical Geology, 172, 131- 148.

Fuck, R.A., Dantas, E.L., Pimentel, M.M., Botelho, N.F., Armstrong, R., Laux, J.H., Junges, S.L., Soares, J.E., Praxedes, I.F., 2014. Paleoproterozoic crust-formation and reworking events in the 
Tocantins Province, central Brazil: a contribution for Atlantica supercontinent reconstruction. Precambrian Research. 244, 53-74.

Fuck, R.A., Jardim de Sá, E.F., Pimentel, M.M., Dardenne, M.A., Soares, A.C.P., 1993. As faixas de dobramentos marginais do Cráton São Francisco: Síntese dos conhecimentos. In: Dominguez, J.M.L., Misi, A. (Eds.), O Cráton do São Francisco. 161-185. (In Portuguese).

Fuck, R.A., Pimentel, M.M., D’el Rey Silva, L.J.H. 1994. Compartimentamção tectônica da porção oriental da Província Tocantins. In: Anais de Congresso Brasileiro de Geologia. 38, 215-216. (In Portuguese).

Fuck, R.A., Pimentel, M.M., Soares, J.E.P., Dantas, E.L. 2005. Compartimentação da Faixa Brasília. In: Anais de Simpósio de Geologia do Centro-Oeste. 9, 26-27. (In Portuguese).

Gioia S.M.C.L., 1997. Preparação da Metodologia Sm-Nd para Datação de Amostras Geológicas e sua Aplicação em Rochas das Áreas de Firminópolis, Fazenda Nova e Americano do Brasil—GO. Unpublished M.S.c Thesis, University of Brasília. 100p. (In Portuguese).

Gioia S.M.C.L, Pimentel M.M., 2000. The Sm-Nd isotopic method in the Geochronology Laboratory of the University of Brasília. Anais da Academia Brasileira de Ciências. 72, 2, 219-245.

Götzinger M. A., 1987. Mineralogy and Genesis of Vermiculite in Serpentinites of the Bohemian Massif in Austria. Springer Wien. Heidelberg - Germany. Mineralogy and Petrology. 36, 2, 93-110.

Grant, 1986. The Isocon Diagram A Simple Solution to Gresens' Equation for Metasomatic Alteration. Economic Geology. 81, 1976-1982.

Grant, 2005. Isocon analysis: A brief review of the method and applications. Physics and Chemistry of the Earth.30, 997-1004.

Gruner, J W., 1934. The structures of vermiculites and their collapse by dehydration. American Mineralogist. 19, 557-575.

Guimarães, S,B. Moura, M, A. Dantas, E . L., 2012. Petrology and geochronology of Bom Jardim copper deposit. Brazilian Journal of Geology. 42, 4, 841-862.

Harraz H.Z. e Hamdy M.M., 2010. Interstratified vermiculite-mica in the gneiss-metapelite-serpentinite rocks at Hafafit area, Southern Eastern Desert, Egypt: From metasomatism to weathering. Journal of African Earth Sciences. 305-320.

Hawthorne, F. C., Oberti, R., Harlow, G. E., Maresch, W. V., Martin, R. F., Schumacher, J. C., Welch, M. D., 2012. IMA report, nomenclature of the amphibole supergroup. American Mineralogist. 97, 2031-2048.

Heaman L. M., 2009. The application of U-Pb geochronology to mafic, ultramafic and alkaline rocks: an evaluation of three mineral standards. Chemical Geology. 261,43-52.

Higgins, J. B., Ribbe, P.H., 1976. The crystal chemistry and space groups of natural and synthetic titanites. American Mineralogist. 61, 878-888.

Hindman J. R., 1992. Vermiculite. In: Industrial Minerals and Rocks. Society for Mining, Metallurgy, and Exploration. London - UK. 5, 1103-1111.

Jackson S. E., Pearson N. J., Griffin W. L., Belousova E. A., 2004. The application of laser ablation inductively coupled plasma mass spectrometry to in situ U-Pb zircon geochronology. Chemical Geology. 211, 47-69.

Johannes, W., 1668. Experimental Investigation of the Reaction Forsterite $+\mathrm{H} 20 \rightleftharpoons$ Serpentine + Brucite. Contribution to Mineralogy and Petrology. 19, 309-315.

Jost, H., Fuck, R.A., Dantas, E.L., Rancan, C.C., Rezende D. de B., Santos, E., Portela, J. F., Mattos, L., Chiarini M.F.N., Oliveira, R.C. de, Sérgio Eduardo e Silva, E., 2005. Geologia e geocronologia do complexo Uvá, bloco Arqueano de Goiás. Revista Brasileira de Geociências. 35, 4, 559-572.

Junges S.L., Pimentel M.M., Moraes R., 2002. Nd isotopic study of the Neoproterozoic Mara Rosa Arc, central Brazil: implications for the evolution of the Brasília Belt. Precambrian Research. 117, 101118.

Justo, A., Maqueda, C., Perez-Rodriguez, J.L., Lagaly, G., 1987. An unusually expandable low-charge vermiculite. Clay Minerals 22, 319-327.

Kalinowski, B.E., Schweda, P., 2007. Rates and nonstoichiometry of vermiculite dissolution at $22{ }^{\circ} \mathrm{C}$. Geoderma 142, 197-209.

Kulp J.L., Brobst, D. A., 1954. Notes on the dunite and the geochemistry of vermiculite at the day book dunite deposit, Yancey County, North Carolina. Economic Geology. 49, 211 - 220.

Lacerda Filho., J. V., Moreira, M. L. O., Moreton L. C., Borges, A. J., Frasca, A. A. S., Melo, L. C., Bispo, P. S., Dias, N., 2000. Programa de Levantamentos Geológicos Básicos do Brasil. Geologia e Recursos Minerais do Estado de Goiás e Distrito Federal. Escala 1:500 000, $2^{\mathrm{a}}$ edição, Goiânia, CPRM/SMET-GO/METAGO/UnB, Texto Explicativo. CD-ROM. (In Portuguese). 
Laux J.H., Pimentel M.M., Dantas E.L., Armstrong R., Armele A., Nilson A. A., 2004. Mafic magmatism associated with the Goiás Magmatic Arc in the Anicuns region, Goiás central Brazil: Sm-Nd isotopes and new ID-TIMS and SHIRIMP U-Pb data. Journal of South American Earth Sciences. 16, 7, 599-614.

Laux, J.H., Pimentel, M.M., Dantas, E.L. Armstrong, R., Junges, S.L., 2005. Two Neoproterozoic crustal events in the Brasília Belt, central Brazil. Journal of South American Earth Sciences.183-198.

Locock A.J., 2014. An Excel spreadsheet to classify chemical analyses of amphiboles following the IMA 2012 recommendations. Computers \& Geosciences. 62, 1-11.

Ludwig, K. R. 2012. User's Manual for Isoplot 3.75: A geochronological toolkit for Microsoft Excel. Berkeley Geochronology Center Special Publication. 5, 75p.

Marques, G. C. 2009. Geologia dos grupos Araí e Serra da Mesa e seu embasamento no sul do Tocantins. Unpublished M.S.c thesis, University of Brasília. 116p. (In Portuguese).

Marques, G. C., Oliveira, C. G., Pimentel M.M., 2016. The Jaupaci Belt (770-500 Ma), Goiás Magmatic Arc: $\mathrm{U}-\mathrm{Pb}$ and $\mathrm{Sm}-\mathrm{Nd}$ isotopic data and implications for the tectonic evolution of a Neoproterozoic Arc in Central Brazil. Precambrian Research. Submmited.

Matteini, M., Junges S. L., Dantas, E. L., Pimentel, M. M., Buhn, B. 2010. In Situ Zircon U-Pb and Lu-Hf isotope systematic on magmatic rocks: insight on the crustal evolution Neoproterizoic Goiás Magmatic Arc, Brasília belt, Central Brazil. Gondwana Research.17, 1-12.

Middelburg, J.J., van der Weijden C. H., Woittiez, J.R.W., 1988. Chemical processes affecting the mobility of Major, minor and trace elements during Weathering of granitic rocks. Chemical Geology. 68, 253-273.

Moraes, R., Brown, M., Fuck, R. A., Camargo, M. A., Lima, T. M., 2002. Characterization and P-T evolution of melt-bearing ultrahigh-temperature granulites: an example from the Anápolis-Itauçu Complex of the Brasília Fold Belt, Brazil. Journal of Petrology. 43, 9, 1673-1705.

Moraes, R., Fuck, R.A., Brown, M., Piccoli, P., Baldwin, J., Dantas, E.L., Laux, J.H., Junges, S., 2007. Wollastonite-scapolite-clinopyroxenemarble of the Anápolis-Itauçu Complex, Goiás: more evidence of ultrahigh-temperature metamorphism. Revista Brasileira de Geociencias. 37, 4, 11-17.

Mota e Silva, J.; Ferreira Filho, C.F.; Bühn, B. e Dantas E.L., 2011. Geology, petrology and geochemistry of the -Americano do Brasill layered intrusion, central Brazil, and its $\mathrm{Ni}-\mathrm{Cu}$ sulfide deposits. Mineralium Deposita. 46, 57-90.

Motta-Araújo, J.G., 2012. Eventos Ígneos e metamórficos neoproterozoicos/eo-paleozoicos no arco magmático de Arenópolis, Goiás. Unpublished Phd thesis, University of Brasília, 73p.

Nilson, A.A, Gioia,S., Pimentel,M.M., 1997, Idade Sm-Nd do Complexo Máfico-Ultramáfico de Americano do Brasil, Goiás e características isotópicas das rochas encaixantes. In: Anais Congresso Brasileiro de Geoquímica. Salvador. 6, 2, 643-645. (In Portuguese).

Nilson, A. A., Santos, M. M., Cuba E. A., Sá C. M. G., 1986. Jazida de níquel, cobre e cobalto de Americano do Brasil, Goiás. In: Schobbenhaus C, Coelho CES (eds) Principais Depósitos Minerais do Brasil II. 257-273. (In Portuguese).

Oberti, R., Cannillo, E., Toscani, G., 2012. How to name amphiboles after the IMA 2012 report: rules of thumb and a new PC program for monoclinic amphiboles. Periodico di Mineralogia 81,257-267.

Olivatti, O., Reis da Silva, C.A., 2008. Dossiê vermiculita. Relatório interno de pesquisa. Unpublished.

Oliveira, C.G., Oliveira F.B., Della Giustina, M.E.S., Marques, G.C., Dantas E. L., Pimentel, M.M., Buhn, B.M., 2015. The Chapada $\mathrm{Cu}-\mathrm{Au}$ deposit, Mara Rosa magmatic arc, Central Brazil: Constraints on the metallogenesis of a Neoproterozoic large porphyry-type deposit. Ore Geology Reviews. 72, 1-21.

Pimentel, M. M., Fuck, R.A., 1986. Geologia da sequencia vulcanosedimentar de Arenópolis (GO). Revista Brasileira de Geociências. 16, 217-223. (In Portuguese).

Pimentel, M. M., Fuck, R. A., 1992. Neoproterozoic crustal accretion in central Brazil. Geology. 20, $375-$ 379.

Pimentel, M. M., Fuck, R. A. 1994. Geocronologia Rb-Sr da porção sudeste do maciço de Goiás. Revista Brasileira de Geociências. 24, 2, 104-111. (In Portuguese).

Pimentel, M. M., Fuck, R. A., Alvarenga, C. J. S., 1996. Post-Brasiliano (Pan-African) high-K granitic magmatism in central Brazil: late precambrian/early Paleozoic extension. Precambrian Research. 80, 217-238.

Pimentel, M.M., Fuck, R.A., Ferreira Filho, C.F., Araújo, S.M., 2000. The basement of the Brasília Belt and the Goiás Magmatic Arc. In: Cordani, U.G., Milani, E.J., Thomaz Filho, A., Campos, D.A. (eds) Tectonic Evolution of South America. 31st International Geological Congress, Rio de Janeiro. 195229. 
Pimentel, M.M., Fuck., R.A., Fischel, D.P., Gioia, S.M.C.L., Moraes, R., 2001. Two Neoproterozoic high-grade metamorphic events in the Brasília Belt, Central Brazil. In: Simp. Sul-Americano de Geologia Isotópica, SSAGI 3, Pucón, Chile, Extended Abst. Volume CD-ROM. Sociedad Geolica del Chile, Santiago, pp. 205-208.

Pimentel M.M., Heaman L., Fuck R.A. 1991. U-Pb zircon and sphenc geochronology of late Protcrozoic volcanic arc rock units from southwestern Goiás, Central Brazil. Journal of South American Earth Sciences. 4, 329-339.

Pimentel M. M., Jost H., Fuck R. A., 2004. O Embasamento da Faixa Brasília e o Arco magmático de Goiás. Geologia do Continente Sul-Americano: evolução da obra de Fernando Flávio Marques de Almeida. Ed. Beca, São Paulo. 31, 355-368.

Pimentel, M.M., Whitehouse, M.J., Viana, M.G., Fuck, R.A., Machado, N., 1997. The Mara Rosa Arc in the Tocantins Province: further evidence for Neoproterozoic crustal accretion in central Brazil. Precambrian Res. 81, 299-310.

Pirajno, F., 2010. Intracontinental strike-slip faults, associated magmatism, mineral systems and mantle dynamics: examples from NW China and Altay-Sayan (Siberia). Journal of Geodynamics. 50, 325346.

Praxedes, I. F., 2015. Lineamento Transbrasiliano, contribuição aerogeofísica, tectônica e geocronológica no setor nordeste da Faixa Brasília. Unpublished M.S.c thesis. University of Brasília, 106p.

Rollinson, H.R., 1993. Using trace element data in Using Geochemical Data: Evaluation, Presentation, Interpretation Longman Scientific \& Technical, London. $102-171$.

Roy, R., Romo, L. A., 1957. Weathering studies. 1. New data on vermiculite. The Journal of Geology. 65,6, $603-610$.

Schärer, U., Zhang, L.-S., Tapponnier, P., 1994. Duration of strike-slip movements in large shear zones: the Red River belt, China. Earth and Planetary Science Letters. 126, 379-397.

Shau, Y., Yang, H., Peacor, D. R., 1991. On oriented titanite and rutile inclusions in sagenitic biotite. American Mineralogist. 76,1205-1217.

Silva, F.O., 1991. Geologia, estrutura, petrologia e mineralização de Fe, Ti e V associadas ao complexo gabro-anortosítico acamadado de Santa Bárbara (Goiás). Unpublished M.S.c thesis, University de Brasília, 190 p. (In Portuguese).

Silva, H. H. A. B., 2006. Caracterização mineralógica e filiação da vermiculita da mina Cerrado III Sanclerlândia-GO. Unpublishes M.S.c thesis, Instituto de Geociências, University of Brasília. 126 p. (In Portuguese).

Soares, J.E., Berrocal, J., Fuck, R.A., Mooney, W.D., Ventura, D.B.R., 2006. Seismic characteristics of central Brazil crust and upper mantle: A deep seismic refraction study. Journal of Geophysical Research 111, 1-31.

Sun S. S., McDonough W. F., 1989. Chemical and isotopic systematics of oceanic basalts: implications for mantle composition and processes. In: Saunders AD, Norry MJ (eds) Magmatism in the Ocean Basins. Geological Society, London, Special Publications. 42, 313-345.

Tera, F., Wasseburg, G. J., 1972. U-Th-Pb systematics in three apollo 14 basalts and the problem of initial pb in lunar rocks. Earth and Planetary Science Letters. 6, 281 - 304.

Valeriano, C. M.; Pimentel, M. M.; Heilbron, M.; Almeida, J. C. H.; Trouw, R. A. J. 2008. Tectonic evolution of the Brasília Belt, Central Brazil, and early assembly of Gondwana. In: PANKHURST, R. J.; TROUW, R. A. J.; BRITO NEVES, B. B.; DE WIT, M. J. (Eds.) West Gondwana: PreCenozoic Correlations Across the South Atlantic Region. Geological Society, London, Special Publications, 294, 197-210.

Verts, L.A., Chamberlain, K.R., Frost, C.D., 1996. U-Pb sphene dating of metamorphism: the importance of sphene growth in the contact aureole of the Red Mountain Pluton, Laramie Mountains, Wyoming. Contrib. Mineral. Petrol. 125, 186-199. von Blackenburg, F., 1992. Combined high-precision chronometry and geochemical tracing using accessory minerals: applied to the Central-Alpine Bergell intrusion_central Europe.. Chemical Geology. 100, 19-40.

Viana, M.G., Pimentel, M.M., Whitehouse, M.J., Fuck, R.A., Machado, N., 1995. O arco magmático de Mara Rosa, Goiás: dados geoquímicos e geocronológicos e suas implicações regionais. Revista Brasileira de Geociêcias. 25 ,2, 111-123. (In Portuguese).

Whitney, D. L., Evans, B.W., 2010. Abbreviations for names of rock-forming minerals. American Mineralogist. 95, 185-187.

Winter, J. D., 2013., Continental Alkaline Magmatism in Principles of Igneous and Metamorphic Petrology $2^{\text {nd }}$ Edition. 415-453.

Wones D. R., 1965. Stability of biotite: Experiment, Theory, and Application ${ }^{1}$ American Mineralogist. 50, 1228-1272. 
Zhou, J., Wang, X., Qiu J., Gao, J., 2004. Geochemistry of Meso- and Neoproterozoic mafic-ultramafic rocks from northern Guangxi, China: Arc or plume magmatism?. Geochemical Journal. 38, 139 152. 


\section{CONCLUSÃO}

Na literatura os corpos ultramáficos próximos à cidade de São Luís de Montes Belos estão inseridos na Suíte Americano do Brasil, porém algumas características desses corpos (item 1.3) são o suficiente para caracteriza-los como pertencentes a uma suíte distinta. As informações obtidas nesse estudo corroboram com a hipótese desses corpos pertencerem à outra suíte ultramáfica distinta, nomeada neste trabalho como Suíte São Luís de Montes Belos (SSLMB).

Os corpos da SSLMB consistem de peridotitos e clinopiroxenito predominantemente alterados para serpentina - magnetita - vermiculita - flogopitito e vermiculita - flogopitito, respectivamente. A sequencia de cristalização ígnea é definida por $\mathrm{Ol}>\mathrm{Ol}+\mathrm{Cpx}>\mathrm{Ol}+\mathrm{Cpx}+\mathrm{Phl}>\mathrm{Cpx}+\mathrm{Phl}$. Valores composicionais da olivina $\left(\mathrm{Fo}_{83.29}-\right.$ 87.18) ígnea, sugerem magmatismo parental primitivo.

As características texturais, estruturais, geoquímica de rocha total e o $\varepsilon N d(T) d a$ SSLMB foram fundamentais para diferenciar essas rochas dos demais complexos intrudidos no AMA e propor um ambiente de formação para essas rochas. A ausência dos efeitos do metaformismo regional, valores negativos de $\varepsilon \mathrm{Nd}(\mathrm{T})$ e elevada concentração de elementos compatíveis e incompatíveis, principalmente elevada concentração de potássio, sugerem que esses corpos se alojaram ao AMA após o final do fechamento da Faixa Brasília, com magmatismo derivado do manto metassomatizado. Tais características permitiram sugerir um contexto de formação da SSLMB em um ambiente de subducção, envolvendo hidratação e metassomatismo da cunha mantélica.

A datação U-Pb obtida em titanita associada à alteração de diopsídio em vrm flogopititos acusou idade de $556 \pm 19 \mathrm{Ma}$, semelhante a alguns granitoides alcalinos da Suíte Serra Negra, interpretados como produto de fusão parcial da crosta continental inferior. A idade e elevado conteúdo de potássio dos granitoides da Suíte Serra Negra, características comuns aos diques e veios hospedados na SSLMB, sugerem que o processo de formação dos diques e veios pode ser análogo à formação desses granitoides. 
O magmatismo que gerou tanto as rochas da SSLMB quantos os diques félsicos podem ter ascendido por meio da zona de cisalhamento transcorrente São Luís de Montes Belos.

Os fluidos hidrotermais pós-magmáticos que formaram os diques e veios foram os principais responsáveis pelo hidrotermalismo dos corpos da SSLMB, assim como em Libby (EUA), Hafafit (Egito) e nos corpos do Maciço da Bohemia (Austria). Na SSLMB, os fluidos contribuíram para a formação da flogopita. Em alguns locais ocorrem lamelas com núcleo de flogopita e borda de vermiculita evidenciando o processo de vermiculitização da mica. Esse processo ocorre por metassomatismo, no final do evento hidrotermal, porém a formação da vermiculita ocorre predominantemente durante o intemperismo. 


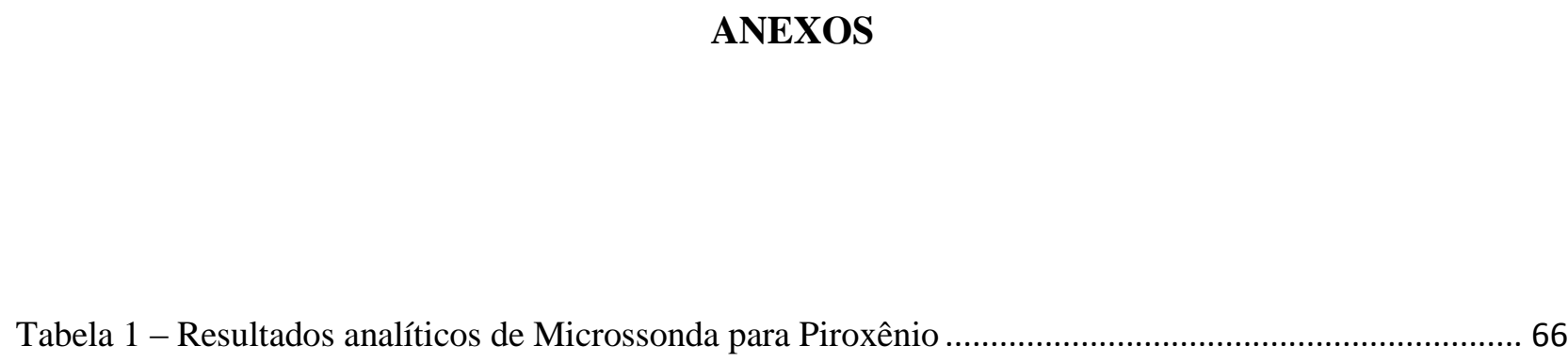

Tabela 2 - Resultados analíticos de Flogopita.* na = não analisado...................................................... 67

Tabela 3 - Resultados analíticos de Anfibólios. Abreviação mineral segundo Whitney e Evans (2010) Ath

$=$ Antofilita $; \mathrm{Hbl}=$ Hornblenda $;$ Act $=$ Actinolita $\mathrm{e} \operatorname{Tr}=$ Tremolita 69

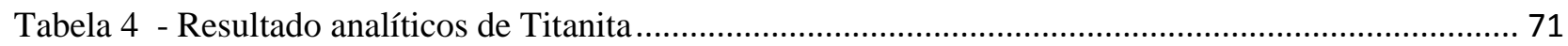

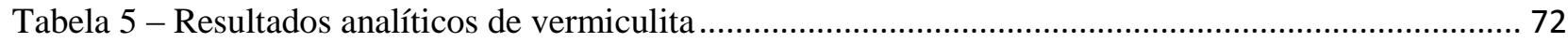

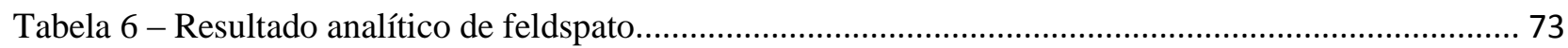


Tabela 1 - Resultados analíticos de Microssonda para Piroxênio

\begin{tabular}{|c|c|c|c|c|c|c|c|c|c|c|c|c|}
\hline Rock & \multicolumn{11}{|c|}{ Clinopyroxenite/Vrm - Phlogopitite } & \multirow{3}{*}{\begin{tabular}{|c} 
Peridotite \\
Fs123- \\
93,95m \\
FS123-III \\
CII_11
\end{tabular}} \\
\hline Sample & \multicolumn{2}{|c|}{ AM17B } & \multicolumn{3}{|c|}{ AM 21} & \multicolumn{3}{|c|}{ FS-123-90,92m } & \multirow{2}{*}{$\begin{array}{c}\begin{array}{c}\text { Fs33- } \\
\text { Top }\end{array} \\
\text { A } \\
\text { CI_10 }\end{array}$} & \multicolumn{2}{|c|}{ FS17 - 28,65m } & \\
\hline $\begin{array}{c}\text { Analysis } \\
(\%)\end{array}$ & C1_49 & C1_51 & C6_03 & C2_21 & C2_22 & \begin{tabular}{|c} 
IV \\
CI_2
\end{tabular} & $\begin{array}{c}\text { IV } \\
\text { CI_3 }\end{array}$ & $\begin{array}{c}\text { IV } \\
\text { CII_10 }\end{array}$ & & $\begin{array}{c}31 \\
\text { C3_15 }\end{array}$ & $\begin{array}{c}17 \\
\text { cpI_2 }\end{array}$ & \\
\hline $\mathrm{SiO}_{2}$ & 53.20 & 52.89 & 53.70 & 53.01 & 53.08 & 54.28 & 54.30 & 54.15 & 53.48 & 53.25 & 54.79 & 53.41 \\
\hline $\mathrm{TiO}_{2}$ & 0.00 & 0.00 & 0.17 & 0.34 & 0.03 & 0.00 & 0.09 & 0.03 & 0.02 & 0.03 & 0.67 & 0.10 \\
\hline $\mathrm{Al}_{2} \mathrm{O}_{3}$ & 0.89 & 0.91 & 0.64 & 0.80 & 0.83 & 0.80 & 0.29 & 0.74 & 0.59 & 1.09 & 0.31 & 1.31 \\
\hline $\mathrm{Cr}_{2} \mathrm{O}_{3}$ & 0.04 & 0.00 & 0.11 & 0.06 & 0.00 & 0.02 & 0.04 & 0.08 & 0.09 & 0.22 & 0.33 & 0.08 \\
\hline $\mathrm{Fe}_{2} \mathrm{O}_{3}$ & 2.76 & 3.90 & 1.22 & 3.46 & 4.00 & 0.29 & 1.25 & 0.39 & 2.84 & 3.75 & 1.75 & 1.35 \\
\hline $\mathrm{FeO}$ & 1.66 & 0.63 & 2.08 & 0.43 & 0.00 & 3.29 & 2.18 & 3.09 & 0.52 & 0.35 & 1.74 & 3.19 \\
\hline $\mathrm{MnO}$ & 0.12 & 0.25 & 0.13 & 0.20 & 0.00 & 0.10 & 0.08 & 0.16 & 0.19 & 0.04 & 0.01 & 0.23 \\
\hline $\mathrm{MgO}$ & 15.84 & 15.96 & 18.06 & 16.19 & 16.47 & 16.39 & 16.55 & 16.51 & 16.98 & 16.06 & 16.59 & 18.11 \\
\hline $\mathrm{CaO}$ & 23.54 & 23.71 & 22.48 & 23.99 & 24.17 & 23.86 & 24.59 & 23.50 & 24.08 & 23.09 & 23.56 & 20.58 \\
\hline $\mathrm{Na}_{2} \mathrm{O}$ & 0.73 & 0.76 & 0.24 & 0.74 & 0.69 & 0.37 & 0.36 & 0.42 & 0.45 & 1.07 & 0.99 & 0.40 \\
\hline $\mathrm{ZnO}$ & 0.00 & 0.00 & 0.06 & 0.00 & 0.00 & 0.01 & 0.00 & 0.00 & 0.00 & 0.14 & NA & 0.00 \\
\hline $\mathrm{NiO}$ & 0.06 & 0.00 & 0.04 & 0.04 & 0.04 & 0.03 & 0.06 & 0.05 & 0.03 & 0.00 & NA & 0.05 \\
\hline Total & 98.83 & 99.01 & 98.90 & 99.27 & 99.32 & 99.44 & 99.79 & 99.11 & 99.28 & 99.10 & 100.74 & 98.80 \\
\hline \multicolumn{13}{|c|}{ number of ions on the base of 6 oxygens } \\
\hline $\mathrm{Si}$ & 1.97 & 1.95 & 1.97 & 1.95 & 1.95 & 1.99 & 1.99 & 1.99 & 1.96 & 1.96 & 1.98 & 1.96 \\
\hline $\mathrm{Al}^{\mathrm{IV}}$ & 0.03 & 0.04 & 0.03 & 0.03 & 0.04 & 0.01 & 0.01 & 0.01 & 0.03 & 0.04 & 0.01 & 0.04 \\
\hline $\mathrm{Al}^{\mathrm{VI}}$ & 0.01 & 0.00 & 0.00 & 0.00 & 0.00 & 0.03 & 0.00 & 0.02 & 0.00 & 0.01 & 0.00 & 0.02 \\
\hline $\mathrm{Fe}^{3+}$ & 0.08 & 0.11 & 0.03 & 0.10 & 0.11 & 0.01 & 0.03 & 0.01 & 0.08 & 0.10 & 0.05 & 0.04 \\
\hline $\mathrm{Cr}$ & 0.00 & 0.00 & 0.00 & 0.00 & 0.00 & 0.00 & 0.00 & 0.00 & 0.00 & 0.01 & 0.01 & 0.00 \\
\hline $\mathrm{Ti}$ & 0.00 & 0.00 & 0.00 & 0.01 & 0.00 & 0.00 & 0.00 & 0.00 & 0.00 & 0.00 & 0.02 & 0.00 \\
\hline $\mathrm{Mg}$ & 0.87 & 0.88 & 0.99 & 0.89 & 0.90 & 0.90 & 0.90 & 0.91 & 0.93 & 0.88 & 0.89 & 0.99 \\
\hline $\mathrm{Fe}^{2+}$ & 0.05 & 0.02 & 0.06 & 0.01 & 0.00 & 0.10 & 0.07 & 0.10 & 0.02 & 0.01 & 0.05 & 0.10 \\
\hline $\mathrm{Mn}$ & 0.00 & 0.01 & 0.00 & 0.01 & 0.00 & 0.00 & 0.00 & 0.00 & 0.01 & 0.00 & 0.00 & 0.01 \\
\hline $\mathrm{Ca}$ & 0.93 & 0.94 & 0.88 & 0.95 & 0.95 & 0.94 & 0.96 & 0.93 & 0.95 & 0.91 & 0.91 & 0.81 \\
\hline $\mathrm{Na}$ & 0.05 & 0.05 & 0.02 & 0.05 & 0.05 & 0.03 & 0.03 & 0.03 & 0.03 & 0.08 & 0.07 & 0.03 \\
\hline $\mathrm{Zn}$ & 0.00 & 0.00 & 0.00 & 0.00 & 0.00 & 0.00 & 0.00 & 0.00 & 0.00 & 0.00 & 0.00 & 0.00 \\
\hline $\mathrm{Ni}$ & 0.00 & 0.00 & 0.00 & 0.00 & 0.00 & 0.00 & 0.00 & 0.00 & 0.00 & 0.00 & 0.00 & 0.00 \\
\hline Cations & 4.00 & 4.00 & 4.00 & 4.00 & 4.00 & 4.00 & 4.00 & 4.00 & 4.00 & 4.00 & 4.00 & 4.00 \\
\hline Wo & 48.22 & 48.24 & 44.87 & 48.68 & 48.44 & 48.26 & 48.98 & 47.80 & 48.06 & 47.75 & 47.86 & 41.81 \\
\hline En & 45.16 & 45.19 & 50.17 & 45.71 & 45.94 & 46.13 & 45.88 & 46.73 & 47.14 & 46.23 & 46.89 & 51.21 \\
\hline Fs & 6.63 & 6.57 & 4.95 & 5.62 & 5.63 & 5.61 & 5.13 & 5.47 & 4.80 & 6.02 & 5.25 & 6.98 \\
\hline
\end{tabular}


Tabela $2-$ Resultados analíticos de Flogopita.* na = não analisado.

\begin{tabular}{|c|c|c|c|c|c|c|c|c|c|c|c|c|c|c|c|c|c|c|c|}
\hline \multirow{3}{*}{$\begin{array}{c}\text { Rock type } \\
\text { Sample } \\
\text { Analysis } \\
\text { (wt } \%)\end{array}$} & \multicolumn{7}{|c|}{ Hornblendite } & \multirow{2}{*}{\multicolumn{12}{|c|}{ Clinopiroxenite/Vrm - phlogopitite }} \\
\hline & \multicolumn{2}{|c|}{ Am20 } & & & \multicolumn{2}{|c|}{ FS33-Bottom } & & & & & & & & & & & & & \\
\hline & $\begin{array}{c}\text { C3 } \\
105\end{array}$ & C3 106 & $\begin{array}{c}\mathrm{C} \mathrm{C} 1 \\
83\end{array}$ & $\begin{array}{c}\mathrm{C} \mathrm{CI} \\
2\end{array}$ & $\begin{array}{c}\mathrm{C} \mathrm{CI} \\
15\end{array}$ & $\begin{array}{c}\mathrm{C} \mathrm{CI} \\
16\end{array}$ & $\begin{array}{c}\text { C CI } \\
17\end{array}$ & C2 59 & C2 61 & C3 67 & C5 11 & C1 26 & C1 27 & C1 30 & $\begin{array}{c}31 \mathrm{C} 4 \\
08\end{array}$ & $\begin{array}{c}31 \mathrm{C} 3 \\
22\end{array}$ & $\begin{array}{c}17 \mathrm{CI} \\
1\end{array}$ & $\begin{array}{c}17 \mathrm{CII} \\
7\end{array}$ & $\begin{array}{c}17 \mathrm{CII} \\
8\end{array}$ \\
\hline $\mathrm{SiO}_{2}$ & 36.44 & 36.15 & 36.83 & 37.33 & 38.51 & 38.75 & 38.76 & 38.13 & 38.32 & 38.13 & 39.01 & 39.30 & 39.14 & 38.50 & 38.69 & 39.42 & 41.34 & 41.29 & 41.01 \\
\hline $\mathrm{TiO}_{2}$ & 1.49 & 1.61 & 1.22 & 1.72 & 0.92 & 1.29 & 1.10 & 1.05 & 1.27 & 1.48 & 1.81 & 1.84 & 1.84 & 1.78 & 1.74 & 1.35 & 1.32 & 1.49 & 1.53 \\
\hline $\mathrm{Al}_{2} \mathrm{O}_{3}$ & 15.76 & 15.85 & 14.77 & 14.16 & 14.51 & 14.17 & 14.41 & 16.04 & 15.78 & 16.13 & 15.00 & 15.50 & 15.19 & 15.30 & 14.26 & 14.40 & 13.76 & 13.46 & 13.48 \\
\hline $\mathrm{Cr}_{2} \mathrm{O}_{3}$ & 0.03 & 0.00 & 0.02 & 0.06 & 0.00 & 0.01 & 0.13 & 0.15 & 0.02 & 0.01 & 0.06 & 0.19 & 0.09 & 0.16 & 0.35 & 0.28 & 0.42 & 0.59 & 0.50 \\
\hline $\mathrm{Fe}_{2} \mathrm{O}_{3}$ & 0.74 & 1.72 & 3.37 & 2.79 & 0.90 & 2.01 & 1.89 & 0.33 & 2.24 & 0.65 & 0.80 & 1.33 & 1.05 & 1.44 & 2.08 & 2.21 & 0.83 & 1.02 & 1.67 \\
\hline $\mathrm{FeO}$ & 14.24 & 13.47 & 10.19 & 10.98 & 12.53 & 11.76 & 12.04 & 9.03 & 7.29 & 8.44 & 6.43 & 6.03 & 5.81 & 5.88 & 4.33 & 4.60 & 5.92 & 5.50 & 4.76 \\
\hline $\mathrm{MnO}$ & 0.30 & 0.14 & 0.10 & 0.05 & 0.12 & 0.21 & 0.07 & 0.19 & 0.10 & 0.05 & 0.13 & 0.14 & 0.08 & 0.01 & 0.02 & 0.07 & 0.03 & 0.08 & 0.08 \\
\hline $\mathrm{MgO}$ & 14.88 & 15.47 & 18.16 & 17.62 & 17.97 & 18.15 & 18.14 & 19.03 & 19.85 & 19.26 & 20.77 & 21.13 & 20.95 & 20.85 & 22.04 & 22.62 & 22.83 & 22.82 & 23.00 \\
\hline $\mathrm{CaO}$ & 0.03 & 0.02 & 0.00 & 0.00 & 0.06 & 0.02 & 0.05 & 0.05 & 0.05 & 0.01 & 0.03 & 0.04 & 0.02 & 0.03 & 0.00 & 0.00 & 0.04 & 0.01 & 0.01 \\
\hline $\mathrm{Na}_{2} \mathrm{O}$ & 0.12 & 0.13 & 0.17 & 0.14 & 0.22 & 0.22 & 0.21 & 0.11 & 0.07 & 0.03 & 0.11 & 0.15 & 0.13 & 0.15 & 0.33 & 0.29 & 0.38 & 0.32 & 0.30 \\
\hline $\mathrm{K}_{2} \mathrm{O}$ & 9.61 & 9.75 & 9.46 & 9.74 & 10.15 & 9.93 & 9.79 & 9.96 & 9.26 & 10.31 & 10.39 & 10.32 & 10.06 & 10.07 & 10.07 & 9.87 & 10.01 & 10.09 & 9.86 \\
\hline $\mathrm{BaO}$ & 0.67 & 0.85 & 0.52 & 0.43 & na & na & na & 0.30 & 0.36 & 0.20 & 0.27 & 0.25 & 0.18 & 0.27 & 0.15 & 0.28 & NA & NA & NA \\
\hline $\mathrm{ZnO}$ & 0.06 & 0.06 & 0.03 & 0.00 & na & na & na & 0.07 & 0.05 & 0.10 & 0.00 & 0.06 & 0.07 & 0.00 & 0.15 & 0.00 & NA & NA & NA \\
\hline $\mathrm{NiO}$ & 0.03 & 0.08 & 0.08 & 0.04 & 0.09 & 0.03 & 0.00 & 0.26 & 0.15 & 0.04 & 0.13 & 0.13 & 0.05 & 0.07 & 0.16 & 0.09 & 0.07 & 0.14 & 0.12 \\
\hline $\mathrm{F}$ & 0.34 & 0.31 & 0.57 & 0.16 & 0.31 & 0.18 & 0.19 & 0.66 & 0.79 & 0.55 & 0.72 & 0.80 & 0.68 & 0.70 & 0.82 & 0.75 & 0.53 & 0.53 & 0.43 \\
\hline $\mathrm{Cl}$ & 0.04 & 0.03 & 0.03 & 0.01 & 0.07 & 0.00 & 0.01 & 0.00 & 0.02 & 0.01 & 0.01 & 0.01 & 0.00 & 0.00 & 0.02 & 0.00 & 0.02 & 0.03 & 0.00 \\
\hline $\mathrm{H}_{2} \mathrm{O}$ & 3.75 & 3.80 & 3.69 & 3.91 & 3.88 & 3.99 & 3.99 & 3.74 & 3.68 & 3.81 & 3.76 & 3.77 & 3.79 & 3.75 & 3.68 & 3.78 & 3.97 & 3.96 & 4.00 \\
\hline Subtotal & 98.53 & 99.43 & 99.19 & 99.14 & 100.2 & 100.3 & 100.8 & 99.10 & 99.31 & 99.21 & 99.42 & 101 & 99.12 & 98.94 & 98.88 & 100.0 & 101.5 & 101.3 & 100.8 \\
\hline $\mathrm{O}=\mathrm{F}, \mathrm{Cl}$ & 0.38 & 0.33 & 0.60 & 0.17 & 0.37 & 0.18 & 0.20 & 0.66 & 0.81 & 0.56 & 0.72 & 0.81 & 0.68 & 0.70 & 0.84 & 0.75 & 0.55 & 0.55 & 0.43 \\
\hline Total & 98.15 & 99.10 & 98.59 & 98.97 & 99.88 & 100.54 & 100.58 & 98.45 & 98.49 & 98.65 & 98.70 & 100.17 & 98.45 & 98.25 & 98.04 & 99.27 & 100.91 & 100.76 & 100.33 \\
\hline \multicolumn{20}{|c|}{ Number of ions on the base of 11 oxygens } \\
\hline $\mathrm{Si}$ & 2.77 & 2.74 & 2.77 & 2.80 & 2.84 & 2.85 & 2.84 & 2.80 & 2.81 & 2.79 & 2.84 & 2.81 & 2.84 & 2.81 & 2.82 & 2.84 & 2.92 & 2.92 & 2.91 \\
\hline $\mathrm{Al}^{\mathrm{IV}}$ & 1.23 & 1.26 & 1.23 & 1.20 & 1.16 & 1.15 & 1.16 & 1.20 & 1.19 & 1.21 & 1.16 & 1.19 & 1.16 & 1.19 & 1.18 & 1.16 & 1.08 & 1.08 & 1.09 \\
\hline $\mathrm{Al}^{\mathrm{VI}}$ & 0.19 & 0.15 & 0.08 & 0.06 & 0.11 & 0.07 & 0.09 & 0.19 & 0.17 & 0.19 & 0.12 & 0.12 & 0.14 & 0.12 & 0.05 & 0.06 & 0.06 & 0.04 & 0.04 \\
\hline $\mathrm{Ti}$ & 0.09 & 0.09 & 0.07 & 0.10 & 0.05 & 0.07 & 0.06 & 0.06 & 0.07 & 0.08 & 0.10 & 0.10 & 0.10 & 0.10 & 0.10 & 0.07 & 0.07 & 0.08 & 0.08 \\
\hline $\mathrm{Fe}^{3+}$ & 0.04 & 0.10 & 0.19 & 0.16 & 0.05 & 0.11 & 0.10 & 0.02 & 0.12 & 0.04 & 0.04 & 0.07 & 0.06 & 0.08 & 0.11 & 0.12 & 0.04 & 0.05 & 0.09 \\
\hline $\mathrm{Fe}^{2+}$ & 0.91 & 0.85 & 0.64 & 0.69 & 0.77 & 0.72 & 0.74 & 0.56 & 0.45 & 0.52 & 0.39 & 0.36 & 0.35 & 0.36 & 0.26 & 0.28 & 0.35 & 0.33 & 0.28 \\
\hline $\mathrm{Mn}$ & 0.02 & 0.01 & 0.01 & 0.00 & 0.01 & 0.01 & 0.00 & 0.01 & 0.01 & 0.00 & 0.01 & 0.01 & 0.00 & 0.00 & 0.00 & 0.00 & 0.00 & 0.00 & 0.00 \\
\hline $\mathrm{Mg}$ & 1.69 & 1.75 & 2.04 & 1.97 & 1.98 & 1.99 & 1.98 & 2.09 & 2.17 & 2.10 & 2.25 & 2.25 & 2.27 & 2.27 & 2.40 & 2.43 & 2.40 & 2.40 & 2.43 \\
\hline $\mathrm{Cr}$ & 0.00 & 0.00 & 0.00 & 0.00 & 0.00 & 0.00 & 0.01 & 0.01 & 0.00 & 0.00 & 0.00 & 0.01 & 0.01 & 0.01 & 0.02 & 0.02 & 0.02 & 0.03 & 0.03 \\
\hline $\mathrm{Ni}$ & 0.00 & 0.00 & 0.00 & 0.00 & 0.01 & 0.00 & 0.00 & 0.02 & 0.01 & 0.00 & 0.01 & 0.01 & 0.00 & 0.00 & 0.01 & 0.01 & 0.00 & 0.01 & 0.01 \\
\hline $\mathrm{Ca}$ & 0.00 & 0.00 & 0.00 & 0.00 & 0.00 & 0.00 & 0.00 & 0.00 & 0.00 & 0.00 & 0.00 & 0.00 & 0.00 & 0.00 & 0.00 & 0.00 & 0.00 & 0.00 & 0.00 \\
\hline $\mathrm{Na}$ & 0.02 & 0.02 & 0.02 & 0.02 & 0.03 & 0.03 & 0.03 & 0.02 & 0.01 & 0.00 & 0.01 & 0.02 & 0.02 & 0.02 & 0.05 & 0.04 & 0.05 & 0.04 & 0.04 \\
\hline K & 0.93 & 0.94 & 0.91 & 0.93 & 0.96 & 0.93 & 0.92 & 0.93 & 0.86 & 0.96 & 0.96 & 0.94 & 0.93 & 0.94 & 0.94 & 0.91 & 0.90 & 0.91 & 0.89 \\
\hline $\mathrm{Ba}$ & 0.02 & 0.03 & 0.02 & 0.01 & 0.00 & 0.00 & 0.00 & 0.01 & 0.01 & 0.01 & 0.01 & 0.01 & 0.01 & 0.01 & 0.00 & 0.01 & 0.00 & 0.00 & 0.00 \\
\hline F & 0.08 & 0.07 & 0.13 & 0.04 & 0.07 & 0.04 & 0.04 & 0.15 & 0.18 & 0.13 & 0.16 & 0.18 & 0.16 & 0.16 & 0.19 & 0.17 & 0.12 & 0.12 & 0.10 \\
\hline $\mathrm{Cl}$ & 0.01 & 0.00 & 0.00 & 0.00 & 0.01 & 0.00 & 0.00 & 0.00 & 0.00 & 0.00 & 0.00 & 0.00 & 0.00 & 0.00 & 0.00 & 0.00 & 0.00 & 0.00 & 0.00 \\
\hline $\mathrm{OH}$ & 1.91 & 1.92 & 1.86 & 1.96 & 1.92 & 1.96 & 1.96 & 1.85 & 1.81 & 1.87 & 1.83 & 1.82 & 1.84 & 1.84 & 1.81 & 1.83 & 1.88 & 1.88 & 1.90 \\
\hline Cations & 7.91 & 7.94 & 7.97 & 7.95 & 7.97 & 7.95 & 7.94 & 7.91 & 7.88 & 7.91 & 7.91 & 7.91 & 7.88 & 7.91 & 7.94 & 7.94 & 7.91 & 7.90 & 7.90 \\
\hline $\mathrm{Al}_{\text {total }}$ & 1.41 & 1.41 & 1.31 & 1.25 & 1.26 & 1.23 & 1.25 & 1.39 & 1.36 & 1.39 & 1.28 & 1.31 & 1.30 & 1.32 & 1.23 & 1.22 & 1.14 & 1.12 & 1.13 \\
\hline$\# \mathrm{Mg}$ & 0.64 & 0.65 & 0.71 & 0.70 & 0.71 & 0.70 & 0.70 & 0.78 & 0.79 & 0.79 & 0.84 & 0.84 & 0.85 & 0.84 & 0.86 & 0.86 & 0.86 & 0.86 & 0.87 \\
\hline
\end{tabular}


Tabela 2 (continuação)

\begin{tabular}{|c|c|c|c|c|c|c|c|c|c|c|c|c|c|c|c|c|c|c|}
\hline \multirow{3}{*}{$\begin{array}{c}\text { Rock type } \\
\text { Sample } \\
\begin{array}{c}\text { Analysis } \\
\text { (wt } \%)\end{array}\end{array}$} & \multicolumn{16}{|c|}{ Clinopiroxenite/Vrm - phlogopitite } & \multirow{2}{*}{\multicolumn{2}{|c|}{$\begin{array}{c}\begin{array}{c}\text { Peridotite / Srp-mt- } \\
\text { vrm - phlogopitite }\end{array} \\
\text { FS } 101\end{array}$}} \\
\hline & \multicolumn{2}{|c|}{ FS17 - 28,65m } & \multicolumn{6}{|c|}{ Fs33-Top } & \multicolumn{5}{|c|}{ FS-123-100,19m } & \multirow{2}{*}{\begin{tabular}{|c|}
$\begin{array}{c}\text { FS-123 - } \\
90,92 \mathrm{~m}\end{array}$ \\
IV CI 4 \\
\end{tabular}} & \multicolumn{2}{|c|}{ FS-151 17,7m } & & \\
\hline & $\begin{array}{c}17 \mathrm{CIII} \\
10\end{array}$ & $\begin{array}{c}17 \text { CIV } \\
18\end{array}$ & $\begin{array}{c}\text { A CIII } \\
2\end{array}$ & $\begin{array}{c}\text { A CIII } \\
3\end{array}$ & $\begin{array}{c}\text { A } \mathrm{CIII} \\
4\end{array}$ & $\begin{array}{c}\text { A CII } \\
8\end{array}$ & $\begin{array}{c}\text { A CII } \\
9\end{array}$ & $\begin{array}{c}\text { A CI } \\
13\end{array}$ & $\begin{array}{l}\text { I CIII } \\
12\end{array}$ & $\begin{array}{c}\text { I CII } \\
13\end{array}$ & $\begin{array}{c}\text { I CII } \\
14\end{array}$ & I CI 23 & I CI 24 & & $\begin{array}{c}\text { III CIV } \\
3\end{array}$ & $\begin{array}{c}\text { III CIV } \\
4\end{array}$ & III CI 1 & III CI \\
\hline $\mathrm{SiO}_{2}$ & 41.27 & 40.83 & 39.65 & 39.37 & 40.02 & 39.47 & 39.64 & 40.09 & 39.76 & 39.65 & 39.34 & 39.48 & 39.46 & 39.80 & 39.65 & 39.31 & 37.60 & 40.86 \\
\hline $\mathrm{TiO}_{2}$ & 1.50 & 1.78 & 1.13 & 1.23 & 0.89 & 0.96 & 1.04 & 1.12 & 1.41 & 1.82 & 2.19 & 2.49 & 1.93 & 1.59 & 1.61 & 1.83 & 0.42 & 0.15 \\
\hline $\mathrm{Al}_{2} \mathrm{O}_{3}$ & 14.00 & 13.56 & 13.71 & 13.49 & 13.65 & 13.59 & 13.68 & 13.55 & 14.18 & 14.12 & 14.57 & 14.13 & 14.00 & 13.52 & 14.97 & 15.48 & 12.76 & 12.84 \\
\hline $\mathrm{Cr}_{2} \mathrm{O}_{3}$ & 0.51 & 0.64 & 0.83 & 0.73 & 0.86 & 0.79 & 1.13 & 0.68 & 0.35 & 0.17 & 0.08 & 0.18 & 0.19 & 0.11 & 0.34 & 0.29 & 1.94 & 0.30 \\
\hline $\mathrm{Fe}_{2} \mathrm{O}_{3}$ & 1.57 & 1.59 & 2.67 & 2.88 & 1.87 & 2.23 & 2.97 & 2.92 & 0.65 & 2.33 & 2.07 & 2.52 & 1.00 & 0.96 & 0.00 & 0.00 & 1.59 & 1.67 \\
\hline $\mathrm{FeO}$ & 4.90 & 5.19 & 5.03 & 4.89 & 5.92 & 5.83 & 5.50 & 4.83 & 7.42 & 6.51 & 6.64 & 5.92 & 7.77 & 6.46 & 9.82 & 9.72 & 6.87 & 2.30 \\
\hline $\mathrm{MnO}$ & 0.04 & 0.02 & 0.00 & 0.14 & 0.00 & 0.09 & 0.12 & 0.12 & 0.07 & 0.10 & 0.16 & 0.07 & 0.14 & 0.09 & 0.04 & 0.00 & 0.14 & 0.00 \\
\hline $\mathrm{MgO}$ & 23.02 & 22.66 & 22.76 & 22.55 & 22.23 & 22.56 & 22.09 & 23.07 & 20.67 & 20.62 & 20.26 & 20.50 & 20.03 & 21.60 & 18.41 & 18.25 & 25.52 & 26.17 \\
\hline $\mathrm{CaO}$ & 0.02 & 0.00 & 0.03 & 0.04 & 0.05 & 0.02 & 0.04 & 0.07 & 0.10 & 0.03 & 0.07 & 0.00 & 0.02 & 0.00 & 0.02 & 0.05 & 0.03 & 0.08 \\
\hline $\mathrm{Na}_{2} \mathrm{O}$ & 0.39 & 0.33 & 0.18 & 0.26 & 0.18 & 0.15 & 0.28 & 0.22 & 0.16 & 0.12 & 0.28 & 0.13 & 0.15 & 0.18 & 0.07 & 0.08 & 0.21 & 0.16 \\
\hline $\mathrm{K}_{2} \mathrm{O}$ & 9.80 & 10.17 & 9.95 & 9.68 & 9.47 & 10.37 & 9.07 & 9.74 & 9.84 & 9.35 & 9.42 & 9.61 & 10.02 & 10.30 & 9.98 & 10.05 & 9.15 & 10.10 \\
\hline $\mathrm{BaO}$ & na & na & 0.16 & 0.28 & 0.33 & 0.19 & 0.32 & 0.30 & 0.12 & 0.10 & 0.31 & 0.37 & 0.19 & 0.41 & 0.05 & 0.19 & 0.22 & 0.33 \\
\hline $\mathrm{ZnO}$ & na & na & 0.02 & 0.02 & 0.09 & 0.00 & 0.00 & 0.06 & 0.18 & 0.00 & 0.04 & 0.04 & 0.01 & 0.00 & 0.11 & 0.04 & 0.03 & 0.08 \\
\hline $\mathrm{NiO}$ & 0.25 & 0.14 & 0.11 & 0.18 & 0.15 & 0.14 & 0.16 & 0.18 & 0.10 & 0.07 & 0.06 & 0.09 & 0.02 & 0.18 & 0.10 & 0.12 & 0.15 & 0.14 \\
\hline $\mathrm{F}$ & 0.51 & 0.46 & 0.28 & 0.47 & 0.46 & 0.22 & 0.42 & 0.44 & 0.37 & 0.36 & 0.19 & 0.24 & 0.27 & 0.37 & 0.24 & 0.42 & 0.13 & 0.32 \\
\hline $\mathrm{Cl}$ & 0.01 & 0.03 & 0.01 & 0.01 & 0.02 & 0.01 & 0.03 & 0.02 & 0.06 & 0.06 & 0.03 & 0.02 & 0.00 & 0.02 & 0.00 & 0.01 & 0.02 & 0.00 \\
\hline $\mathrm{H}_{2} \mathrm{O}$ & 4.01 & 3.99 & 4.03 & 3.90 & 3.92 & 4.04 & 3.93 & 3.97 & 3.92 & 3.92 & 4.03 & 4.01 & 3.97 & 3.93 & 3.99 & 3.90 & 4.07 & 4.04 \\
\hline Subtotal & 101.78 & 101.38 & 100.54 & 100.12 & 100.11 & 100.67 & 100.43 & 101.37 & 99.35 & 99.35 & 99.73 & 99.78 & 99.18 & 99.53 & 99.41 & 99.73 & 100.85 & 99.54 \\
\hline $\mathrm{O}=\mathrm{F}, \mathrm{Cl}$ & 0.52 & 0.49 & 0.28 & 0.48 & 0.48 & 0.23 & 0.45 & 0.45 & 0.43 & 0.43 & 0.22 & 0.26 & 0.27 & 0.40 & 0.24 & 0.42 & 0.15 & 0.32 \\
\hline Total & 101.26 & 100.89 & 100.26 & 99.64 & 99.63 & 100.44 & 99.98 & 100.92 & 98.92 & 98.92 & 99.51 & 99.52 & 98.91 & 99.14 & 99.17 & 99.31 & 100.71 & 99.22 \\
\hline \multicolumn{19}{|c|}{ Number of ions on the base of 11 oxygens } \\
\hline $\mathrm{Si}$ & 2.90 & 2.89 & 2.85 & 2.85 & 2.88 & 2.85 & 2.86 & 2.86 & 2.89 & 2.88 & 2.85 & 2.86 & 2.88 & 2.89 & 2.89 & 2.86 & 2.65 & 2.91 \\
\hline $\mathrm{Al}^{\mathrm{IV}}$ & 1.10 & 1.11 & 1.15 & 1.15 & 1.12 & 1.15 & 1.14 & 1.14 & 1.11 & 1.12 & 1.15 & 1.14 & 1.12 & 1.11 & 1.11 & 1.14 & 1.06 & 1.08 \\
\hline $\mathrm{Al}{ }^{\mathrm{VI}}$ & 0.06 & 0.02 & 0.01 & 0.00 & 0.04 & 0.00 & 0.02 & 0.00 & 0.10 & 0.09 & 0.09 & 0.07 & 0.08 & 0.05 & 0.18 & 0.19 & 0.00 & 0.00 \\
\hline $\mathrm{Ti}$ & 0.08 & 0.09 & 0.06 & 0.07 & 0.05 & 0.05 & 0.06 & 0.06 & 0.08 & 0.10 & 0.12 & 0.14 & 0.11 & 0.09 & 0.09 & 0.10 & 0.02 & 0.01 \\
\hline $\mathrm{Fe}^{3+}$ & 0.08 & 0.08 & 0.14 & 0.16 & 0.10 & 0.12 & 0.16 & 0.16 & 0.04 & 0.13 & 0.11 & 0.14 & 0.05 & 0.05 & 0.00 & 0.00 & 0.08 & 0.09 \\
\hline $\mathrm{Fe}^{2+}$ & 0.29 & 0.31 & 0.30 & 0.30 & 0.36 & 0.35 & 0.33 & 0.29 & 0.45 & 0.40 & 0.40 & 0.36 & 0.47 & 0.39 & 0.60 & 0.59 & 0.40 & 0.14 \\
\hline $\mathrm{Mn}$ & 0.00 & 0.00 & 0.00 & 0.01 & 0.00 & 0.01 & 0.01 & 0.01 & 0.00 & 0.01 & 0.01 & 0.00 & 0.01 & 0.01 & 0.00 & 0.00 & 0.01 & 0.00 \\
\hline $\mathrm{Mg}$ & 2.41 & 2.39 & 2.44 & 2.43 & 2.39 & 2.42 & 2.37 & 2.45 & 2.24 & 2.23 & 2.19 & 2.21 & 2.18 & 2.34 & 2.00 & 1.98 & 2.68 & 2.78 \\
\hline $\mathrm{Cr}$ & 0.03 & 0.04 & 0.05 & 0.04 & 0.05 & 0.05 & 0.06 & 0.04 & 0.02 & 0.01 & 0.00 & 0.01 & 0.01 & 0.01 & 0.02 & 0.02 & 0.11 & 0.02 \\
\hline $\mathrm{Ni}$ & 0.01 & 0.01 & 0.01 & 0.01 & 0.01 & 0.01 & 0.01 & 0.01 & 0.01 & 0.00 & 0.00 & 0.01 & 0.00 & 0.01 & 0.01 & 0.01 & 0.01 & 0.01 \\
\hline $\mathrm{Ca}$ & 0.00 & 0.00 & 0.00 & 0.00 & 0.00 & 0.00 & 0.00 & 0.01 & 0.01 & 0.00 & 0.01 & 0.00 & 0.00 & 0.00 & 0.00 & 0.00 & 0.00 & 0.01 \\
\hline $\mathrm{Na}$ & 0.05 & 0.05 & 0.02 & 0.04 & 0.02 & 0.02 & 0.04 & 0.03 & 0.02 & 0.02 & 0.04 & 0.02 & 0.02 & 0.03 & 0.01 & 0.01 & 0.03 & 0.02 \\
\hline $\mathrm{K}$ & 0.88 & 0.92 & 0.91 & 0.89 & 0.87 & 0.95 & 0.83 & 0.89 & 0.91 & 0.87 & 0.87 & 0.89 & 0.93 & 0.95 & 0.93 & 0.93 & 0.82 & 0.92 \\
\hline $\mathrm{Ba}$ & 0.00 & 0.00 & 0.00 & 0.01 & 0.01 & 0.01 & 0.01 & 0.01 & 0.00 & 0.00 & 0.01 & 0.01 & 0.01 & 0.01 & 0.00 & 0.01 & 0.01 & 0.01 \\
\hline F & 0.11 & 0.10 & 0.06 & 0.11 & 0.11 & 0.05 & 0.10 & 0.10 & 0.09 & 0.08 & 0.04 & 0.05 & 0.06 & 0.09 & 0.05 & 0.10 & 0.03 & 0.07 \\
\hline $\mathrm{Cl}$ & 0.00 & 0.00 & 0.00 & 0.00 & 0.00 & 0.00 & 0.00 & 0.00 & 0.01 & 0.01 & 0.00 & 0.00 & 0.00 & 0.00 & 0.00 & 0.00 & 0.00 & 0.00 \\
\hline $\mathrm{OH}$ & 1.89 & 1.89 & 1.94 & 1.89 & 1.89 & 1.95 & 1.90 & 1.90 & 1.91 & 1.91 & 1.95 & 1.94 & 1.94 & 1.91 & 1.95 & 1.90 & 1.97 & 1.93 \\
\hline Cations & 7.89 & 7.91 & 7.95 & 7.95 & 7.91 & 7.99 & 7.91 & 7.95 & 7.88 & 7.85 & 7.86 & 7.85 & 7.88 & 7.93 & 7.83 & 7.84 & 7.88 & 7.99 \\
\hline $\mathrm{Al}_{\text {total }}$ & 1.16 & 1.13 & 1.16 & 1.15 & 1.16 & 1.15 & 1.16 & 1.14 & 1.21 & 1.21 & 1.24 & 1.21 & 1.20 & 1.16 & 1.29 & 1.33 & 1.06 & 1.08 \\
\hline \#Mg & 0.87 & 0.86 & 0.85 & 0.84 & 0.84 & 0.84 & 0.83 & 0.85 & 0.82 & 0.81 & 0.81 & 0.82 & 0.80 & 0.84 & 0.77 & 0.77 & 0.85 & 0.92 \\
\hline
\end{tabular}


Tabela 3 - Resultados analíticos de Anfibólios. Abreviação mineral segundo Whitney e Evans (2010) Ath = Antofilita; Hbl = Hornblenda; Act $=$ Actinolita e $\operatorname{Tr}=$ Tremolita.

\begin{tabular}{|c|c|c|c|c|c|c|c|c|c|c|c|c|c|c|c|}
\hline \multirow{4}{*}{$\begin{array}{c}\text { Rock } \\
\text { Sample } \\
\text { Analysis } \\
\text { wt }(\%)\end{array}$} & \multirow{2}{*}{\multicolumn{5}{|c|}{ Ath Vein }} & \multicolumn{10}{|c|}{ Hornblendite } \\
\hline & & & & & & \multirow{2}{*}{\multicolumn{3}{|c|}{$\frac{\text { Type II }}{\text { AM22 }}$}} & \multirow{2}{*}{\multicolumn{2}{|c|}{$\begin{array}{l}\text { Type I } \\
\text { AM20 }\end{array}$}} & \multirow{2}{*}{\multicolumn{5}{|c|}{$\begin{array}{l}\text { Type II } \\
\text { AM27 }\end{array}$}} \\
\hline & \multicolumn{3}{|c|}{ AM13 } & \multicolumn{2}{|c|}{ AM17A } & & & & & & & & & & \\
\hline & $\mathrm{C} 14$ & $\begin{array}{l}\mathrm{C} 3 \\
15\end{array}$ & $\begin{array}{l}\text { C3 } \\
16\end{array}$ & $\begin{array}{l}\mathrm{C} 4 \\
33\end{array}$ & $\begin{array}{l}\text { C3 } \\
40\end{array}$ & $\begin{array}{l}\mathrm{C} 2 \\
122\end{array}$ & $\begin{array}{l}\mathrm{C} 2 \\
124\end{array}$ & $\begin{array}{c}\mathrm{C} 3 \\
125\end{array}$ & $\begin{array}{c}\mathrm{C} 1 \\
108\end{array}$ & $\begin{array}{c}\mathrm{C} 2 \\
115\end{array}$ & $\begin{array}{l}\mathrm{C} 3 \\
69\end{array}$ & $\begin{array}{l}\text { C3 } \\
72\end{array}$ & $\begin{array}{l}\mathrm{C} 1 \\
78\end{array}$ & $\begin{array}{l}\text { C1 } \\
79\end{array}$ & $\begin{array}{l}\mathrm{C} 1 \\
81\end{array}$ \\
\hline Species & \multicolumn{5}{|c|}{ Ath } & \multicolumn{3}{|c|}{ Act } & \multicolumn{7}{|c|}{$\mathrm{Hbl}$} \\
\hline $\mathrm{SiO}_{2}$ & 56.87 & 57.12 & 56.03 & 55.65 & 55.67 & 49.36 & 50.53 & 51.02 & 42.64 & 43.24 & 48.75 & 48.86 & 48.35 & 48.90 & 48.46 \\
\hline $\mathrm{TiO}_{2}$ & 0.00 & 0.00 & 0.03 & 0.31 & 0.14 & 0.28 & 0.41 & 0.09 & 1.04 & 0.50 & 0.62 & 0.45 & 0.17 & 0.53 & 0.31 \\
\hline $\mathrm{Al}_{2} \mathrm{O}_{3}$ & 0.06 & 0.04 & 0.09 & 0.03 & 0.04 & 5.75 & 5.41 & 4.74 & 11.45 & 11.18 & 7.02 & 6.81 & 6.59 & 6.98 & 7.00 \\
\hline $\mathrm{Fe}_{2} \mathrm{O}_{3}$ & 2.41 & 2.78 & 3.84 & 3.44 & 4.33 & 1.34 & 0.77 & 1.83 & 5.84 & 5.33 & 0.34 & 1.03 & 2.59 & 0.61 & 1.00 \\
\hline $\mathrm{FeO}$ & 9.18 & 8.47 & 6.92 & 7.51 & 7.84 & 6.34 & 6.74 & 5.78 & 8.68 & 9.15 & 8.05 & 7.43 & 5.92 & 7.37 & 7.16 \\
\hline $\mathrm{MnO}$ & 0.17 & 0.29 & 0.36 & 0.40 & 0.53 & 0.21 & 0.22 & 0.17 & 0.25 & 0.20 & 0.09 & 0.14 & 0.20 & 0.21 & 0.10 \\
\hline $\mathrm{MgO}$ & 27.57 & 28.13 & 28.30 & 27.91 & 27.57 & 18.35 & 18.53 & 18.95 & 12.49 & 12.71 & 17.53 & 17.69 & 17.96 & 17.85 & 17.72 \\
\hline $\mathrm{CaO}$ & 0.39 & 0.34 & 0.25 & 0.35 & 0.33 & 12.44 & 12.41 & 12.59 & 11.53 & 11.78 & 12.22 & 12.35 & 12.37 & 12.23 & 12.26 \\
\hline $\mathrm{Na}_{2} \mathrm{O}$ & 0.05 & 0.04 & 0.05 & 0.05 & 0.03 & 1.43 & 1.27 & 1.18 & 1.83 & 1.95 & 1.53 & 1.52 & 1.51 & 1.56 & 1.56 \\
\hline $\mathrm{K}_{2} \mathrm{O}$ & 0.00 & 0.00 & 0.05 & 0.02 & 0.01 & 0.50 & 0.40 & 0.35 & 1.23 & 1.17 & 0.65 & 0.56 & 0.56 & 0.57 & 0.63 \\
\hline $\mathrm{ZnO}$ & 0.17 & 0.02 & 0.11 & 0.03 & 0.03 & 0.00 & 0.00 & 0.14 & 0.10 & 0.08 & 0.00 & 0.00 & 0.00 & 0.00 & 0.00 \\
\hline $\mathrm{Cr}_{2} \mathrm{O}_{3}$ & 0.00 & 0.00 & 0.00 & 0.00 & 0.04 & 0.10 & 0.05 & 0.08 & 0.00 & 0.00 & 0.22 & 0.26 & 0.07 & 0.17 & 0.07 \\
\hline $\mathrm{NiO}$ & 0.00 & 0.04 & 0.15 & 0.09 & 0.11 & 0.02 & 0.13 & 0.00 & 0.00 & 0.12 & 0.03 & 0.00 & 0.08 & 0.06 & 0.01 \\
\hline $\mathrm{SrO}$ & 0.00 & 0.07 & & 0.05 & & 0.00 & & & 0.01 & 0.00 & 0.05 & 0.00 & 0.00 & 0.00 & 0.00 \\
\hline $\mathrm{P}_{2} \mathrm{O}_{5}$ & 0.00 & 0.00 & & 0.01 & 0.00 & 0.06 & & 0.03 & 0.01 & 0.00 & 0.00 & 0.01 & 0.00 & 0.00 & 0.00 \\
\hline $\mathrm{H}_{2} \mathrm{O}$ & 2.15 & 2.12 & 2.10 & 2.11 & & 2.01 & 2 & 2.01 & 1. & 1.88 & 1.91 & 1.96 & 2.00 & 1.95 & 1.95 \\
\hline F & 0.08 & 0.15 & 0.17 & 0.15 & 0.07 & 0.20 & 0.24 & 0.22 & 0.26 & 0.31 & 0.39 & 0.28 & 0.21 & 0.30 & 0.31 \\
\hline $\mathrm{Cl}$ & 0.00 & 0.00 & 0.02 & 0.01 & 0.00 & 0.00 & 0.00 & 0.00 & 0.00 & 0.02 & 0.00 & 0.01 & 0.01 & 0.02 & 0.01 \\
\hline $\mathrm{O}=\mathrm{F}, \mathrm{Cl}$ & -0.04 & -0.06 & -0.08 & -0.06 & -0.03 & -0.09 & & -0.09 & -0.11 & -0.14 & -0.16 & -0.12 & -0.09 & -0.13 & -0.13 \\
\hline Total & 99.06 & 99.54 & 98.43 & 98.05 & 98.87 & 98.31 & 99.01 & 99.14 & 99.15 & 99.47 & 99.23 & 99.24 & 98.49 & 99.18 & 98.40 \\
\hline \multicolumn{16}{|c|}{ number of ions on the base of 23 oxygens } \\
\hline $\mathrm{Si}$ & 7.88 & 7.86 & 1.19 & 1.18 & 7.75 & 7.14 & 7.24 & 7.29 & 6.34 & 6.41 & 7.03 & 7.04 & 7.01 & 7.04 & 7.03 \\
\hline $\mathrm{P}$ & 0.00 & 0.00 & 0.00 & 0.00 & 0.00 & 0.01 & 0.00 & 0.00 & 0.00 & 0.00 & 0.00 & 0.00 & 0.00 & 0.00 & 0.00 \\
\hline $\mathrm{Al}^{\mathrm{IV}}$ & 0.01 & 0.01 & 0.02 & 0.01 & 0.01 & 0.85 & 0.76 & 0.71 & 1.66 & 1.59 & 0.97 & 0.96 & 0.99 & 0.96 & 0.97 \\
\hline $\mathrm{Al}^{\mathrm{VI}}$ & 0.00 & 0.00 & 0.00 & 0.00 & 0.00 & 0.13 & 0.16 & 0.09 & 0.34 & 0.36 & 0.23 & 0.20 & 0.14 & 0.22 & 0.23 \\
\hline $\mathrm{Ti}$ & 0.00 & 0.00 & 0.00 & 0.03 & 0.02 & 0.03 & 0.05 & 0.01 & 0.12 & 0.06 & 0.07 & 0.05 & 0.02 & 0.06 & 0.03 \\
\hline $\mathrm{Fe}^{3+}$ & 0.25 & 0.29 & 0.40 & 0.36 & 0.45 & 0.15 & 0.08 & 0.20 & 0.65 & 0.60 & 0.04 & 0.11 & 0.28 & 0.07 & 0.11 \\
\hline $\mathrm{Fe}^{2+}$ & 1.06 & 0.98 & 0.80 & 0.88 & 0.91 & 0.77 & 0.81 & 0.69 & 1.08 & 1.13 & 0.97 & 0.90 & 0.72 & 0.89 & 0.87 \\
\hline $\mathrm{Mn}^{3+}$ & 0.00 & 0.00 & 0.00 & 0.00 & 0.00 & 0.00 & 0.00 & 0.00 & 0.00 & 0.00 & 0.00 & 0.00 & 0.00 & 0.00 & 0.00 \\
\hline $\mathrm{Mn}^{2+}$ & 0.02 & 0.03 & 0.04 & 0.05 & 0.06 & 0.03 & 0.03 & 0.02 & 0.03 & 0.03 & 0.01 & 0.02 & 0.03 & 0.03 & 0.01 \\
\hline $\mathrm{Mg}$ & 5.69 & 5.77 & 5.86 & 5.82 & 5.72 & 3.96 & 3.96 & 4.04 & 2.77 & 2.81 & 3.77 & 3.80 & 3.88 & 3.83 & 3.83 \\
\hline $\mathrm{Cr}$ & 0.00 & 0.00 & 0.00 & 0.00 & 0.00 & 0.01 & 0.01 & 0.01 & 0.00 & 0.00 & 0.03 & 0.03 & 0.01 & 0.02 & 0.01 \\
\hline $\mathrm{Ni}$ & 0.00 & 0.01 & 0.02 & 0.01 & 0.01 & 0.00 & 0.02 & 0.00 & 0.00 & 0.01 & 0.00 & 0.00 & 0.01 & 0.01 & 0.00 \\
\hline $\mathrm{Zn}$ & 0.02 & 0.00 & 0.01 & 0.00 & 0.00 & 0.00 & 0.00 & 0.02 & 0.01 & 0.01 & 0.00 & 0.00 & 0.00 & 0.00 & 0.00 \\
\hline $\mathrm{Ca}$ & 0.06 & 0.05 & 0.04 & 0.05 & 0.05 & 1.93 & 1.91 & 1.93 & 1.84 & 1.87 & 1.89 & 1.91 & 1.92 & 1.89 & 1.91 \\
\hline $\mathrm{Na}$ & 0.01 & 0.01 & 0.01 & 0.01 & 0.01 & 0.40 & 0.35 & 0.33 & 0.53 & 0.56 & 0.43 & 0.43 & 0.42 & 0.44 & 0.44 \\
\hline $\mathrm{Sr}$ & 0.00 & 0.01 & 0.00 & 0.00 & 0.00 & 0.00 & 0.00 & 0.01 & 0.00 & 0.00 & 0.00 & 0.00 & 0.00 & 0.00 & 0.00 \\
\hline $\mathrm{K}$ & 0.00 & 0.00 & 0.01 & 0.00 & 0.00 & 0.09 & 0.07 & 0.06 & 0.23 & 0.22 & 0.12 & 0.10 & 0.10 & 0.10 & 0.12 \\
\hline $\mathrm{Cl}$ & 0.00 & 0.00 & 0.01 & 0.00 & 0.00 & 0.00 & 0.00 & 0.00 & 0.00 & 0.01 & 0.00 & 0.00 & 0.00 & 0.00 & 0.00 \\
\hline F & 0.04 & 0.07 & 0.08 & 0.07 & 0.03 & 0.09 & 0.11 & 0.10 & 0.12 & 0.15 & 0.18 & 0.13 & 0.09 & 0.14 & 0.14 \\
\hline $\mathrm{OH}$ & 1.96 & 1.94 & 1.92 & 1.93 & 1.97 & 1.91 & 1.89 & 1.90 & 1.88 & 1.85 & 1.82 & 1.87 & 1.90 & 1.86 & 1.86 \\
\hline Catic & 15.00 & 15.00 & 15.01 & 15.01 & 15.01 & 15.40 & 15.35 & 15.32 & 15.59 & 15.66 & 15.55 & 15.53 & 15.53 & 15.54 & 15.55 \\
\hline$\# \mathrm{Mg}$ & 0.81 & 0.82 & 0.83 & 0.82 & 0.81 & 0.81 & 0.82 & 0.82 & 0.62 & 0.62 & \begin{tabular}{|l|}
0.79 \\
\end{tabular} & 0.79 & 0.80 & 0.80 & 0.80 \\
\hline
\end{tabular}


Tabela 3 (continuação)

\begin{tabular}{|c|c|c|c|c|c|c|c|c|c|c|c|c|c|c|c|c|}
\hline \multirow{3}{*}{$\begin{array}{c}\text { Rock } \\
\text { Sample }\end{array}$} & \multirow{2}{*}{\multicolumn{4}{|c|}{$\begin{array}{c}\text { Hornblendite } \\
\text { Type II }\end{array}$}} & \multirow{2}{*}{\multicolumn{3}{|c|}{ Pyroxenite }} & \multirow{2}{*}{\multicolumn{9}{|c|}{ Peridotite }} \\
\hline & & & & & & & & & & & & & & & & \\
\hline & \multicolumn{4}{|c|}{ FS33 - Bottom } & \multicolumn{3}{|c|}{ FS-123-100,19m } & \multicolumn{4}{|c|}{ AM17D } & \multicolumn{4}{|c|}{ FS 101} & \multirow{2}{*}{$\begin{array}{l}\text { FS-123- } \\
93,95 \mathrm{~m} \\
\text { III CI } 6\end{array}$} \\
\hline $\begin{array}{l}\text { Analysis } \\
\text { wt( }(\%)\end{array}$ & $\begin{array}{c}\mathrm{C} \mathrm{C} 2 \\
77\end{array}$ & $\begin{array}{c}\mathrm{C} \mathrm{C} 2 \\
78\end{array}$ & $\begin{array}{l}\mathrm{C} 1 \\
81\end{array}$ & $\begin{array}{c}\mathrm{C} \mathrm{C} 1 \\
82\end{array}$ & $\begin{array}{l}\text { I CIV } \\
3\end{array}$ & $\begin{array}{l}\text { I CIV } \\
5\end{array}$ & $\begin{array}{l}\text { I CII } \\
16\end{array}$ & $\begin{array}{l}\mathrm{C} 1 \\
50\end{array}$ & $\begin{array}{l}\mathrm{C} 3 \\
64\end{array}$ & $\begin{array}{l}\mathrm{C} 3 \\
65\end{array}$ & $\begin{array}{l}\mathrm{C} 4 \\
75\end{array}$ & $\begin{array}{c}\text { III CII } \\
1\end{array}$ & $\begin{array}{c}\text { III } \\
\text { CII } 2\end{array}$ & $\begin{array}{c}\text { III } \\
\text { CII } 5\end{array}$ & $\begin{array}{c}\text { III } \\
\text { CIV } 1\end{array}$ & \\
\hline Species & Act & \multicolumn{3}{|c|}{$\mathrm{Hbl}$} & \multicolumn{3}{|c|}{ Act } & \multicolumn{9}{|c|}{$\mathrm{Tr}$} \\
\hline $\mathrm{SiO}_{2}$ & 49.96 & 45.68 & 45.90 & 45.59 & 55.61 & 54.75 & 55.88 & 57.23 & 56.28 & 56.56 & 56.16 & 57.06 & 56.24 & 56.02 & 56.79 & 54.21 \\
\hline $\mathrm{TiO}_{2}$ & 0.26 & 0.20 & 0.56 & 0.59 & 0.07 & 0.00 & 0.00 & 0.00 & 0.03 & 0.00 & 0.06 & 0.08 & 0.24 & 0.30 & 0.00 & 0.20 \\
\hline $\mathrm{Al}_{2} \mathrm{O}_{3}$ & 5.18 & 8.77 & 8.47 & 8.83 & 1.80 & 2.34 & 1.91 & 0.18 & 0.32 & 0.17 & 0.20 & 0.83 & 1.59 & 1.53 & 0.88 & 2.39 \\
\hline $\mathrm{Fe}_{2} \mathrm{O}_{3}$ & 2.91 & 4.19 & 3.69 & 3.47 & 2.08 & 2.66 & 1.75 & 2.57 & 3.43 & 3.01 & 2.78 & 1.49 & 1.30 & 1.5 & 1.22 & 2.04 \\
\hline $\mathrm{FeO}$ & 7.05 & 7.80 & 8.57 & 9.18 & 2.86 & 2.72 & 3.36 & 1.11 & 0.00 & 0.26 & 0.70 & 1.27 & 1.06 & 1.29 & 0.99 & 1.81 \\
\hline $\mathrm{MnO}$ & 0.04 & 0.09 & 0.21 & 0.09 & 0.22 & 0.03 & 0.01 & 0.06 & 0.18 & 0.10 & 0.29 & 0.08 & 0.12 & 0.07 & 0.11 & 0.04 \\
\hline $\mathrm{MgO}$ & 17.57 & 15.51 & 15.28 & 14.75 & 21.67 & 20.93 & 21.14 & 23.75 & 23.71 & 23.56 & 23.26 & 23.68 & 23.71 & 23.23 & 23.51 & 22.03 \\
\hline $\mathrm{CaO}$ & 11.95 & 12.17 & 11.46 & 11.74 & 12.47 & 12.39 & 12.35 & 12.32 & 12.37 & 12.52 & 12.28 & 12.72 & 12.72 & 13.02 & 12.88 & 12.43 \\
\hline $\mathrm{Na}_{2} \mathrm{O}$ & 1.63 & 1.97 & 2.03 & 1.79 & 0.52 & 0.79 & 0.65 & 0.22 & 0.21 & 0.18 & 0.19 & 0.35 & 0.58 & 0.46 & 0.44 & 0.64 \\
\hline $\mathrm{K}_{2} \mathrm{O}$ & 0.22 & 0.86 & 0.83 & 0.95 & 0.23 & 0.26 & 0.21 & 0.02 & 0.05 & 0.04 & 0.02 & 0.10 & 0.17 & 0.12 & 0.08 & 0.16 \\
\hline $\mathrm{ZnO}$ & 0.00 & 0.12 & 0.00 & 0.00 & 0.00 & 0.05 & 0.07 & 0.16 & 0.03 & 0.00 & 0.00 & 0.00 & 0.00 & 0.00 & 0.00 & 0.04 \\
\hline $\mathrm{Cr}_{2} \mathrm{O}_{3}$ & 0.02 & 0.17 & 0.17 & 0.12 & 0.10 & 0.12 & 0.00 & 0.05 & 0.02 & 0.00 & 0.05 & 0.00 & 0.01 & 0.12 & 0.04 & 0.00 \\
\hline $\mathrm{NiO}$ & 0.04 & 0.07 & 0.00 & 0.06 & 0.00 & 0.05 & 0.14 & 0.06 & 0.01 & 0.03 & 0.15 & 0.06 & 0.08 & 0.10 & 0.07 & 0.00 \\
\hline $\mathrm{SrO}$ & 0.00 & 0.00 & 0.02 & 0.00 & 0.07 & 0.00 & 0.00 & 0.00 & 0.00 & 0.00 & 0.00 & 0.03 & 0.00 & 0.07 & 0.00 & 0.10 \\
\hline $\mathrm{P}_{2} \mathrm{O}_{5}$ & 0.00 & 0.04 & 0.06 & 0.08 & 0.01 & 0.00 & 0.00 & 0.00 & 0.01 & 0.10 & 0.00 & 0.06 & 0.00 & 0.02 & 0.03 & 0.08 \\
\hline $\mathrm{H}_{2} \mathrm{O}$ & 2.00 & 1.93 & 1.92 & 1.91 & 2.16 & 2.15 & 2.16 & 2.12 & 2.1 & 2.12 & 2.13 & 2.18 & 2.18 & 2.17 & 2.19 & 2.15 \\
\hline $\mathrm{F}$ & 0.21 & 0.28 & 0.30 & 0.29 & 0.00 & 0.00 & 0.01 & 0.15 & 0.20 & 0.15 & 0.10 & 0.00 & 0.00 & 0.00 & 0.00 & 0.00 \\
\hline $\mathrm{Cl}$ & 0.00 & 0.00 & 0.01 & 0.01 & 0.03 & 0.05 & 0.00 & 0.00 & 0.00 & 0.00 & 0.00 & 0.03 & 0.03 & 0.06 & 0.02 & 0.08 \\
\hline $\mathrm{O}=\mathrm{F}, \mathrm{Cl}$ & -0.09 & -0.12 & -0.13 & -0.12 & -0.01 & -0.01 & 0.00 & -0.06 & -0.08 & -0.06 & -0.04 & -0.01 & -0.01 & -0.01 & 0.00 & -0.02 \\
\hline Total & 98.95 & 99.70 & 99.35 & 99.34 & 99.80 & 99.16 & 99.63 & 99.94 & 98.90 & 98.75 & 98.33 & 100.02 & 99.99 & 99.94 & 99.22 & 98.37 \\
\hline \multicolumn{17}{|c|}{ number of ions on the base of 23 oxygens } \\
\hline $\mathrm{Si}$ & 7.21 & 6.67 & 6.72 & 6.70 & 7.71 & 7.66 & 7.76 & 7.85 & 7.79 & 7.83 & 7.83 & 7.81 & 7.71 & 7.70 & 7.83 & 7.61 \\
\hline $\mathrm{P}$ & 0.00 & 0.01 & 0.01 & 0.01 & 0.00 & 0.00 & 0.00 & 0.00 & 0.00 & 0.01 & 0.00 & 0.01 & 0.00 & 0.00 & 0.00 & 0.01 \\
\hline $\mathrm{Al}^{\mathrm{IV}}$ & 0.79 & 1.33 & 1.27 & 1.30 & 0.29 & 0.34 & 0.24 & 0.03 & 0.05 & 0.03 & 0.03 & 0.13 & 0.26 & 0.25 & 0.14 & 0.39 \\
\hline $\mathrm{Al}^{\mathrm{VI}}$ & 0.09 & 0.18 & 0.19 & 0.23 & 0.01 & 0.04 & 0.07 & 0.00 & 0.00 & 0.00 & 0.00 & 0.00 & 0.00 & 0.00 & 0.00 & 0.01 \\
\hline $\mathrm{Ti}$ & 0.03 & 0.02 & 0.06 & 0.07 & 0.01 & 0.00 & 0.00 & 0.00 & 0.00 & 0.00 & 0.01 & 0.01 & 0.03 & 0.03 & 0.00 & 0.02 \\
\hline $\mathrm{Fe}^{3+}$ & 0.32 & 0.46 & 0.41 & 0.39 & 0.22 & 0.28 & 0.18 & 0.26 & 0.36 & 0.31 & 0.29 & 0.15 & 0.13 & 0.16 & 0.13 & 0.22 \\
\hline $\mathrm{Fe}^{2+}$ & 0.85 & 0.92 & 0.98 & 1.07 & 0.33 & 0.32 & 0.39 & 0.13 & 0.00 & 0.03 & 0.08 & 0.15 & 0.12 & 0.15 & 0.11 & 0.21 \\
\hline $\mathrm{Mn}^{3+}$ & 0.00 & 0.00 & 0.00 & 0.00 & 0.00 & 0.00 & 0.00 & 0.00 & 0.02 & 0.00 & 0.00 & 0.00 & 0.00 & 0.00 & 0.00 & 0.00 \\
\hline $\mathrm{Mn}^{2+}$ & 0.01 & 0.01 & 0.03 & 0.01 & 0.03 & 0.00 & 0.00 & 0.01 & 0.00 & 0.01 & 0.03 & 0.01 & 0.01 & 0.01 & 0.01 & 0.01 \\
\hline $\mathrm{Mg}$ & 3.78 & 3.38 & 3.34 & 3.23 & 4.48 & 4.36 & 4.38 & 4.86 & 4.89 & 4.86 & 4.84 & 4.83 & 4.84 & 4.76 & 4.83 & 4.61 \\
\hline $\mathrm{Cr}$ & 0.00 & 0.02 & 0.02 & 0.01 & 0.00 & 0.00 & 0.00 & 0.01 & 0.00 & 0.00 & 0.01 & 0.00 & 0.00 & 0.00 & 0.00 & 0.00 \\
\hline $\mathrm{Ni}$ & 0.01 & 0.01 & 0.00 & 0.01 & 0.00 & 0.01 & 0.02 & 0.01 & 0.00 & 0.00 & 0.02 & 0.01 & 0.01 & 0.01 & 0.01 & 0.00 \\
\hline $\mathrm{Zn}$ & 0.00 & 0.01 & 0.00 & 0.00 & 0.00 & 0.01 & 0.01 & 0.02 & 0.00 & 0.00 & 0.00 & 0.00 & 0.00 & 0.00 & 0.00 & 0.00 \\
\hline $\mathrm{Ca}$ & 1.85 & 1.90 & 1.80 & 1.85 & 1.85 & 1.86 & 1.84 & 1.81 & 1.83 & 1.86 & 1.84 & 1.87 & 1.87 & 1.92 & 1.90 & 1.87 \\
\hline $\mathrm{Na}$ & 0.46 & 0.56 & 0.58 & 0.51 & 0.14 & 0.21 & 0.17 & 0.06 & 0.06 & 0.05 & 0.05 & 0.09 & 0.16 & 0.12 & 0.12 & 0.18 \\
\hline $\mathrm{Sr}$ & 0.00 & 0.00 & 0.00 & 0.00 & 0.01 & 0.00 & 0.00 & 0.00 & 0.00 & 0.00 & 0.00 & 0.00 & 0.00 & 0.01 & 0.00 & 0.01 \\
\hline $\mathrm{K}$ & 0.04 & 0.16 & 0.16 & 0.18 & 0.04 & 0.05 & 0.04 & 0.00 & 0.01 & 0.01 & 0.00 & 0.02 & 0.03 & 0.02 & 0.02 & 0.03 \\
\hline $\mathrm{Cl}$ & 0.00 & 0.00 & 0.00 & 0.00 & 0.01 & 0.01 & 0.00 & 0.00 & 0.00 & 0.00 & 0.00 & 0.01 & 0.01 & 0.01 & 0.00 & 0.02 \\
\hline $\mathrm{F}$ & 0.09 & 0.13 & 0.14 & 0.14 & 0.00 & 0.00 & 0.00 & 0.07 & 0.09 & 0.07 & 0.04 & 0.00 & 0.00 & 0.00 & 0.00 & 0.00 \\
\hline $\mathrm{OH}$ & 1.91 & 1.87 & 1.86 & 1.86 & 1.99 & 1.99 & 2.00 & 1.94 & 1.91 & 1.93 & 1.94 & 1.99 & 1.99 & 1.99 & 2.00 & 1.98 \\
\hline Cations & 15.28 & 15.34 & 15.27 & 15.23 & 15.07 & 15.09 & 15.06 & 14.96 & 14.93 & 14.94 & 14.98 & 15.07 & 15.13 & 15.11 & 15.09 & 15.12 \\
\hline$\# \mathrm{Mg}$ & 0.76 & 0.71 & 0.71 & 0.69 & 0.89 & 0.88 & 0.88 & 0.93 & 0.93 & 0.93 & 0.93 & 0.94 & 0.95 & 0.94 & 0.95 & 0.92 \\
\hline
\end{tabular}




\begin{tabular}{|c|c|c|c|c|c|c|c|c|c|c|c|c|}
\hline \multirow{4}{*}{$\begin{array}{c}\text { Rock } \\
\text { Sample } \\
\text { Analysis } \\
(\%) \\
\end{array}$} & \multicolumn{7}{|c|}{ Hornblendite } & \multirow{2}{*}{\multicolumn{5}{|c|}{ Phlogopititite }} \\
\hline & \multirow{2}{*}{\multicolumn{2}{|c|}{$\begin{array}{l}\text { Type I } \\
\text { Am } 20\end{array}$}} & \multicolumn{5}{|c|}{ Type II } & & & & & \\
\hline & & & & & S 33 Bo & & & \multicolumn{2}{|c|}{$\begin{array}{l}\text { FS17 - } \\
28,65 \mathrm{~m}\end{array}$} & \multicolumn{3}{|c|}{ Fs33-Top } \\
\hline & $\begin{array}{c}\mathrm{C} 1 \\
110 \\
\end{array}$ & $\begin{array}{c}\mathrm{C} 2 \\
111 \\
\end{array}$ & C CII6 & $\begin{array}{c}\mathrm{C} \mathrm{CII} \\
7\end{array}$ & $\begin{array}{c}\mathrm{C} \mathrm{CII} \\
8 \\
\end{array}$ & $\begin{array}{c}\mathrm{C} \text { cpII } \\
10\end{array}$ & $\begin{array}{c}\mathrm{C} \text { cpII } \\
11\end{array}$ & C4 11 & C4 12 & $\begin{array}{c}\mathrm{A} C \mathrm{CII} \\
5\end{array}$ & $\begin{array}{c}\text { A CII } \\
7 \\
\end{array}$ & $\begin{array}{c}\text { A CI } \\
12 \\
\end{array}$ \\
\hline $\mathrm{SiO}_{2}$ & 29.20 & 29.11 & 30.10 & 30.18 & 30.18 & 30.91 & 30.81 & 29.50 & 28.29 & 30.22 & 29.94 & 30.35 \\
\hline $\mathrm{TiO}_{2}$ & 38.52 & 37.52 & 38.90 & 38.03 & 38.38 & 38.15 & 37.74 & 36.77 & 39.77 & 38.65 & 39.35 & 39.05 \\
\hline $\mathrm{Al}_{2} \mathrm{O}_{3}$ & 1.21 & 1.92 & 1.02 & 1.03 & 1.23 & 0.91 & 1.08 & 1.10 & 1.02 & 0.65 & 0.74 & 0.60 \\
\hline $\mathrm{Cr}_{2} \mathrm{O}_{3}$ & 0.02 & 0.02 & 0.00 & 0.03 & 0.01 & 0.00 & 0.03 & 0.24 & 0.18 & 0.47 & 0.35 & 0.38 \\
\hline $\mathrm{Fe}_{2} \mathrm{O}_{3}$ & 0.49 & 0.55 & 0.84 & 0.78 & 0.91 & 0.77 & 0.81 & 0.65 & 0.50 & 0.50 & 0.75 & 0.52 \\
\hline $\mathrm{MnO}$ & 0.00 & 0.08 & 0.03 & 0.04 & 0.10 & 0.08 & 0.06 & 0.00 & 0.03 & 0.05 & 0.08 & 0.07 \\
\hline $\mathrm{MgO}$ & 0.00 & 0.00 & 0.00 & 0.36 & 0.04 & 0.03 & 0.01 & 0.00 & 0.01 & 0.00 & 0.05 & 0.03 \\
\hline $\mathrm{CaO}$ & 28.60 & 28.47 & 27.75 & 27.72 & 27.87 & 28.56 & 28.53 & 28.73 & 28.13 & 27.71 & 27.47 & 28.11 \\
\hline $\mathrm{Na}_{2} \mathrm{O}$ & 0.00 & 0.02 & 0.02 & 0.05 & 0.00 & 0.03 & 0.01 & 0.02 & 0.03 & 0.03 & 0.04 & 0.01 \\
\hline $\mathrm{K}_{2} \mathrm{O}$ & 0.00 & 0.00 & 0.02 & 0.04 & 0.00 & 0.00 & 0.00 & 0.09 & 0.05 & 0.00 & 0.02 & 0.03 \\
\hline $\mathrm{NiO}$ & 0.03 & 0.00 & 0.06 & 0.00 & 0.01 & 0.06 & 0.00 & 0.00 & 0.00 & 0.00 & 0.00 & 0.01 \\
\hline $\mathrm{BaO}$ & 0.13 & 0.00 & 0.10 & 0.19 & 0.05 & 0.00 & 0.00 & 0.23 & 0.05 & 0.18 & 0.07 & 0.13 \\
\hline $\mathrm{P}_{2} \mathrm{O}_{5}$ & 0.10 & 0.13 & 0.08 & 0.08 & 0.00 & 0.06 & 0.11 & 0.07 & 0.00 & 0.17 & 0.05 & 0.03 \\
\hline $\mathrm{SrO}$ & 0.00 & 0.00 & 0.13 & 0.09 & 0.04 & 0.00 & 0.00 & 0.00 & 0.00 & 0.07 & 0.00 & 0.10 \\
\hline $\mathrm{ZnO}$ & 0.03 & 0.00 & 0.09 & 0.05 & 0.02 & 0.00 & 0.00 & 0.12 & 0.06 & 0.00 & 0.00 & 0.00 \\
\hline $\mathrm{Cl}$ & 0.00 & 0.01 & 0.00 & 0.02 & 0.00 & 0.00 & 0.02 & 0.01 & 0.00 & 0.00 & 0.00 & 0.01 \\
\hline $\mathrm{F}$ & 0.35 & 0.56 & 0.03 & 0.00 & 0.00 & 0.00 & 0.00 & 0.51 & 0.42 & 0.12 & 0.00 & 0.00 \\
\hline $\mathrm{H}_{2} \mathrm{O}$ & 1.46 & 1.84 & 0.84 & 1.33 & 1.15 & 0.05 & 0.35 & 2.19 & 1.64 & 1.23 & 1.08 & 0.58 \\
\hline Total & 98.54 & 98.16 & 100.00 & 100.00 & 100.00 & 100.00 & 100.00 & 97.81 & 98.36 & 100.00 & 100.00 & 100.00 \\
\hline \multicolumn{13}{|c|}{ number of ions on the base of 5 oxygens } \\
\hline $\mathrm{Si}$ & 0.97 & 0.96 & 0.99 & 1.00 & 1.00 & 1.02 & 1.02 & 0.99 & 0.94 & 1.00 & 0.99 & 1.00 \\
\hline $\mathrm{Ti}$ & 0.96 & 0.93 & 0.97 & 0.95 & 0.96 & 0.94 & 0.94 & 0.92 & 0.99 & 0.96 & 0.98 & 0.97 \\
\hline $\mathrm{Al}$ & 0.05 & 0.08 & 0.04 & 0.04 & 0.05 & 0.04 & 0.04 & 0.04 & 0.04 & 0.03 & 0.03 & 0.02 \\
\hline $\mathrm{Cr}$ & 0.00 & 0.00 & 0.00 & 0.00 & 0.00 & 0.00 & 0.00 & 0.01 & 0.00 & 0.01 & 0.01 & 0.01 \\
\hline $\mathrm{Fe}^{3+}$ & 0.01 & 0.02 & 0.02 & 0.02 & 0.03 & 0.02 & 0.02 & 0.02 & 0.01 & 0.01 & 0.02 & 0.01 \\
\hline $\mathrm{Mn}^{3+}$ & 0.00 & 0.00 & 0.00 & 0.00 & 0.00 & 0.00 & 0.00 & 0.00 & 0.00 & 0.00 & 0.00 & 0.00 \\
\hline $\mathrm{Mg}$ & 0.00 & 0.00 & 0.00 & 0.02 & 0.00 & 0.00 & 0.00 & 0.00 & 0.00 & 0.00 & 0.00 & 0.00 \\
\hline $\mathrm{Ca}$ & 1.02 & 1.01 & 0.98 & 0.99 & 0.99 & 1.00 & 1.01 & 1.03 & 1.00 & 0.98 & 0.97 & 0.99 \\
\hline $\mathrm{Na}$ & 0.00 & 0.00 & 0.00 & 0.00 & 0.00 & 0.00 & 0.00 & 0.00 & 0.00 & 0.00 & 0.00 & 0.00 \\
\hline $\mathrm{K}$ & 0.00 & 0.00 & 0.00 & 0.00 & 0.00 & 0.00 & 0.00 & 0.00 & 0.00 & 0.00 & 0.00 & 0.00 \\
\hline $\mathrm{Ni}$ & 0.00 & 0.00 & 0.00 & 0.00 & 0.00 & 0.00 & 0.00 & 0.00 & 0.00 & 0.00 & 0.00 & 0.00 \\
\hline $\mathrm{Zn}$ & 0.00 & 0.00 & 0.00 & 0.00 & 0.00 & 0.00 & 0.00 & 0.00 & 0.00 & 0.00 & 0.00 & 0.00 \\
\hline $\mathrm{Ba}$ & 0.00 & 0.00 & 0.00 & 0.00 & 0.00 & 0.00 & 0.00 & 0.00 & 0.00 & 0.00 & 0.00 & 0.00 \\
\hline $\mathrm{Cl}$ & 0.00 & 0.00 & 0.00 & 0.00 & 0.00 & 0.00 & 0.00 & 0.00 & 0.00 & 0.00 & 0.00 & 0.00 \\
\hline F & 0.04 & 0.06 & 0.00 & 0.00 & 0.00 & 0.00 & 0.00 & 0.05 & 0.04 & 0.01 & 0.00 & 0.00 \\
\hline $\mathrm{OH}$ & 0.02 & 0.03 & 0.06 & 0.06 & 0.07 & 0.06 & 0.06 & 0.01 & 0.01 & 0.03 & 0.05 & 0.04 \\
\hline Cations & 3.01 & 3.00 & 3.02 & 3.03 & 3.02 & 3.03 & 3.03 & 3.02 & 3.00 & 3.01 & 3.01 & 3.02 \\
\hline
\end{tabular}


Tabela 5 - Resultados analíticos de vermiculita

\begin{tabular}{|c|c|c|c|c|c|c|c|c|c|c|c|c|c|c|c|c|c|c|c|c|}
\hline \multirow{3}{*}{$\begin{array}{c}\text { Rock } \\
\text { Sample } \\
\text { Analysis } \\
\mathrm{wt}(\%) \\
\end{array}$} & \multirow{2}{*}{\multicolumn{7}{|c|}{ Mount Bronze 1}} & \multirow{2}{*}{\multicolumn{5}{|c|}{ Mount Bronze 2}} & \multirow{3}{*}{$\begin{array}{c}\text { Mount Prata } 1 \\
\operatorname{Lm} 39\end{array}$} & \multirow{2}{*}{\multicolumn{2}{|c|}{ Mount Prata 2}} & \multicolumn{5}{|c|}{ Peridotite/Srp-mt-vrm - phlogopitite } \\
\hline & & & & & & & & & & & & & & & & \multicolumn{3}{|c|}{ AM24 } & \multicolumn{2}{|c|}{ AM17D } \\
\hline & Lm6 10 & Lm8 14 & Lm9 15 & Lm9 16 & Lm10 17 & Lm11 21 & Lm11 22 & $\operatorname{Lm} 35$ & Lm4 7 & Lm6 12 & Lm7 14 & $\operatorname{Lm} 715$ & & Lm3 Vrm5 & Lm6 13 & C3 48 & C3 50 & C2 59 & C1 47 & C4 80 \\
\hline Type & \multicolumn{12}{|c|}{ II } & \multicolumn{8}{|c|}{ I } \\
\hline $\mathrm{SiO}_{2}$ & 37.74 & 38.42 & 37.72 & 37.80 & 38.02 & 35.19 & 36.09 & 39.68 & 37.35 & 38.86 & 37.40 & 39.61 & 37.84 & 37.56 & 38.93 & 42.16 & 42.10 & 41.16 & 41.35 & 41.99 \\
\hline $\mathrm{TiO}_{2}$ & 1.07 & 1.13 & 1.98 & 2.00 & 1.64 & 1.20 & 1.51 & 1.51 & 1.34 & 0.99 & 1.56 & 1.50 & 0.66 & 0.63 & 0.36 & 0.20 & 0.14 & 0.09 & 0.27 & 0.00 \\
\hline $\mathrm{Al}_{2} \mathrm{O}_{3}$ & 12.33 & 13.30 & 13.20 & 12.89 & 13.00 & 12.27 & 13.00 & 14.30 & 12.84 & 12.53 & 13.35 & 13.94 & 12.45 & 12.46 & 10.53 & 11.81 & 12.08 & 12.28 & 11.16 & 11.62 \\
\hline $\mathrm{Cr}_{2} \mathrm{O}_{3}$ & 0.71 & 0.85 & 0.62 & 0.48 & 0.36 & 0.60 & 0.35 & 0.59 & 1.00 & 0.52 & 0.94 & 0.47 & 0.44 & 0.54 & 0.21 & 0.18 & 0.08 & 0.03 & 0.00 & 0.10 \\
\hline $\mathrm{Fe}_{2} \mathrm{O}_{3}$ & 4.84 & 6.90 & 7.34 & 7.65 & 7.75 & 6.35 & 6.29 & 8.25 & 9.96 & 5.17 & 7.60 & 7.77 & 3.97 & 4.11 & 2.41 & 2.37 & 1.89 & 1.94 & 6.19 & 5.04 \\
\hline $\mathrm{MnO}$ & 0.00 & 0.11 & 0.00 & 0.00 & 0.10 & 0.04 & 0.13 & 0.06 & 0.01 & 0.00 & 0.01 & 0.00 & 0.00 & 0.05 & 0.04 & 0.03 & 0.04 & 0.05 & 0.04 & 0.06 \\
\hline $\mathrm{MgO}$ & 26.46 & 24.54 & 23.50 & 23.18 & 24.81 & 22.63 & 24.18 & 21.92 & 21.53 & 28.13 & 24.25 & 22.80 & 27.04 & 27.69 & 28.47 & 28.76 & 29.99 & 30.04 & 27.02 & 27.61 \\
\hline $\mathrm{CaO}$ & 0.12 & 0.05 & 0.21 & 0.16 & 0.06 & 0.10 & 0.14 & 0.08 & 0.12 & 0.06 & 0.11 & 0.06 & 0.06 & 0.08 & 0.03 & 0.20 & 0.04 & 0.09 & 0.09 & 0.07 \\
\hline $\mathrm{Na}_{2} \mathrm{O}$ & 0.15 & 0.04 & 0.15 & 0.11 & 0.01 & 0.05 & 0.11 & 0.03 & 0.10 & 0.08 & 0.07 & 0.05 & 0.12 & 0.28 & 0.01 & 0.06 & 0.02 & 0.00 & 0.00 & 0.01 \\
\hline $\mathrm{K}_{2} \mathrm{O}$ & 0.14 & 0.12 & 0.05 & 0.05 & 0.02 & 0.27 & 0.37 & 0.72 & 0.29 & 0.42 & 0.16 & 0.03 & 0.10 & 0.06 & 0.25 & 0.36 & 0.31 & 0.10 & 0.06 & 0.02 \\
\hline $\mathrm{NiO}$ & 0.14 & 0.10 & 0.13 & 0.13 & 0.22 & 0.18 & 0.17 & 0.12 & 0.18 & 0.16 & 0.25 & 0.14 & 0.24 & 0.11 & 0.14 & 0.20 & 0.16 & 0.21 & 0.46 & 0.04 \\
\hline $\mathrm{BaO}$ & 0.00 & 0.07 & 0.00 & 0.03 & 0.17 & 0.00 & 0.04 & 0.01 & 0.00 & 0.00 & 0.00 & 0.02 & 0.00 & 0.00 & 0.03 & 0.00 & 0.05 & 0.00 & 0.00 & 0.06 \\
\hline $\mathrm{ZnO}$ & 0.00 & 0.13 & 0.00 & 0.01 & 0.02 & 0.01 & 0.07 & 0.01 & 0.00 & 0.04 & 0.06 & 0.03 & 0 & 0.00 & 0.03 & 0.00 & 0.00 & 0.12 & 0.00 & 0.00 \\
\hline $\mathrm{Cl}$ & 0.01 & 0.00 & 0.00 & 0 & 0.01 & 0.00 & 0.00 & 0 & 0.00 & 0. & 0.00 & 0.00 & 0. & 0 . & 0.01 & 0.02 & 0.02 & 0.02 & 0.01 & 0.02 \\
\hline F & 0.26 & 0.36 & 0.33 & 0.3 & 0.23 & 0.41 & 0.28 & 0.2 & 0.24 & 0.3 & 0.28 & 0.27 & 0 . & 0.1 & 0.15 & 0.43 & 0.46 & 0.43 & 0.55 & 0.54 \\
\hline $\mathrm{H}_{2} \mathrm{O}^{-* *}$ & 3.86 & 3.90 & 3.86 & & 3.95 & 3.55 & 3.77 & 4.00 & 3.85 & 3.95 & 3.91 & 3.98 & 3.89 & 3. & 3.84 & 3.98 & 4.00 & 3.97 & 3.89 & 3.92 \\
\hline $\mathrm{H}_{2} \mathrm{O}^{+* *}$ & 12.17 & 10.00 & 10.92 & 11.34 & 9.63 & 17.13 & 13.51 & 8.41 & 11.18 & 8.69 & 10.05 & 9.33 & 13.08 & 12.37 & 14.58 & 9.25 & 8.63 & 9.49 & 8.90 & 8.90 \\
\hline $\mathrm{O}=\mathrm{F}, \mathrm{Cl}$ & -0.11 & -0.15 & -0.14 & -0.13 & -0.10 & -0.17 & -0.12 & -0.12 & -0.10 & -0.17 & -0.12 & -0.11 & -0.06 & -0.05 & -0.07 & -0.19 & -0.20 & -0.18 & -0.23 & -0.23 \\
\hline Total & 100.11 & 100.15 & 100.14 & 100.13 & 100.10 & 100.17 & 100.12 & 100.12 & 100.10 & 100.17 & 100.12 & 100.11 & 100.06 & 100.05 & 100.07 & 100.19 & 100.20 & 100.18 & 100.23 & 100.23 \\
\hline \multicolumn{21}{|c|}{ number of ions on the basis of 11 oxygens } \\
\hline $\mathrm{Si}$ & 2.84 & 2.83 & 2.81 & 2.83 & 2.81 & 2.81 & 2.77 & 2.88 & 2.82 & 2.81 & 2.78 & 2.89 & 2.87 & 2.83 & 2.98 & 3.02 & 2.99 & 2.96 & 2.98 & 3.01 \\
\hline $\mathrm{Al}^{\mathrm{IV}}$ & 1.09 & 1.16 & 1.16 & 1.14 & 1.13 & 1.16 & 1.18 & 1.12 & 1.14 & 1.07 & 1.17 & 1.11 & 1.11 & 1.11 & 0.95 & 0.98 & 1.01 & 1.04 & 0.95 & 0.98 \\
\hline $\mathrm{Fe}^{3+}$ & 0.07 & 0.01 & 0.03 & 0.03 & 0.06 & 0.03 & 0.05 & 0.00 & 0.03 & 0.12 & 0.06 & 0.00 & 0.02 & 0.06 & 0.06 & 0.00 & 0.00 & 0.00 & 0.07 & 0.01 \\
\hline $\mathrm{Al}^{\mathrm{VI}}$ & 0.00 & 0.00 & 0.00 & 0.00 & 0.00 & 0.00 & 0.00 & 0.10 & 0.00 & 0.00 & 0.00 & 0.09 & 0.00 & 0.00 & 0.00 & 0.01 & 0.00 & 0.00 & 0.00 & 0.00 \\
\hline $\mathrm{Ti}$ & 0.06 & 0.06 & 0.11 & 0.11 & 009 & 0.07 & 0.09 & 0.08 & 0.08 & 0. & 0.09 & 0.08 & 004 & 0.04 & 0.02 & 0.01 & 0.01 & 0.00 & 0.01 & 0.00 \\
\hline $\mathrm{Cr}$ & 0.04 & 0.05 & 0.04 & 0.03 & 0.02 & 0.04 & 0.02 & 0.03 & 0.06 & 0.03 & 0.05 & 0.03 & 0.03 & 0.03 & 0.01 & 0.01 & 0.00 & 0.00 & 0.00 & 0.01 \\
\hline $\mathrm{Fe}^{3+}$ & 0.21 & 0.37 & 0.38 & 0.40 & 0.37 & 0.35 & 0.31 & 0.45 & 0.53 & 0.16 & 0.37 & 0.43 & 0.21 & 0.17 & 0.07 & 0.13 & 0.10 & 0.10 & 0.27 & 0.26 \\
\hline $\mathrm{Mn}$ & 0.00 & 0.01 & 0.00 & 0.00 & 0.01 & 0.00 & 0.01 & 0.00 & 0.00 & 0.00 & 0.00 & 0.00 & 08 & 0.00 & 0.00 & 0.00 & 0.00 & 0.00 & 0.00 & 0.00 \\
\hline $\mathrm{Ni}$ & 0.01 & 0.01 & 0.01 & 0.01 & 0.01 & 0.01 & 0.01 & 0.01 & 0.01 & 0.01 & 0.02 & 0.01 & 0.01 & 0.01 & 0.01 & 0.01 & 0.01 & 0.01 & 0.03 & 0.00 \\
\hline $\mathrm{Mg}$ & 2.68 & 2.50 & 2.46 & 2.45 & 2.50 & 2.52 & 2.56 & 2.33 & 2.32 & 2.74 & 2.48 & 2.36 & 2.71 & 2.75 & 2.88 & 2.83 & 2.87 & 2.88 & 2.69 & 2.73 \\
\hline $\mathrm{Mg}$ & 0.28 & 0.20 & 0.15 & 0.14 & 0.24 & 0.17 & 0.22 & 0.04 & 0.10 & 0.29 & 0.21 & 0.12 & 0.35 & 0.36 & 0.37 & 0.24 & 0.30 & 0.34 & 0.22 & 0.22 \\
\hline $\mathrm{Na}$ & 0.04 & 0.01 & 0.04 & 0.03 & 0.00 & 0.02 & 0.03 & 0.01 & 0.03 & 0.02 & 0.02 & 0.01 & 0.03 & 0.08 & 0.00 & 0.02 & 0.01 & 0.00 & 0.00 & 0.00 \\
\hline $\mathrm{Ca}$ & 0.01 & 0.01 & 0.02 & 0.02 & 0.01 & 0.01 & 0.02 & 0.01 & 0.01 & 0.01 & 0.01 & 0.01 & 0.01 & 0.01 & 0.00 & 0.02 & 0.00 & 0.01 & 0.01 & 0.01 \\
\hline K & 0.03 & 0.02 & 0.01 & 0.01 & 0.00 & 0.06 & 0.07 & 0.13 & 0.06 & 0.08 & 0.03 & 0.00 & 0.02 & 0.01 & 0.05 & 0.07 & 0.06 & 0.02 & 0.01 & 0.00 \\
\hline $\mathrm{Ba}$ & 0.00 & 0.00 & 0.00 & 0.00 & 0.00 & 0.00 & 0.00 & 0.00 & 0.00 & 0.00 & 0.00 & 0.00 & 0.00 & 0.00 & 0.00 & 0.00 & 0.00 & 0.00 & 0.00 & 0.00 \\
\hline $\mathrm{Zn}$ & 0.00 & 0.01 & 0.00 & 0.00 & 0.00 & 0.00 & 0.00 & 0.00 & 0.00 & 0.00 & 0.00 & 0.00 & 0.00 & 0.00 & 0.00 & 0.00 & 0.00 & 0.01 & 0.00 & 0.00 \\
\hline $\mathrm{OH}$ & 1.94 & 1.92 & 1.92 & 1.92 & 1.95 & 1.90 & 1.93 & 1.93 & 1.94 & 1.91 & 1.93 & 1.94 & 1.97 & 1.97 & 1.96 & 1.90 & 1.90 & 1.90 & 1.87 & 1.87 \\
\hline $\mathrm{Cl}$ & 0.00 & 0.00 & 0.00 & 0.00 & 0.00 & 0.00 & 0.00 & 0.00 & 0.00 & 0.00 & 0.00 & 0.00 & 0.00 & 0.00 & 0.00 & 0.00 & 0.00 & 0.00 & 0.00 & 0.00 \\
\hline $\mathrm{F}$ & 0.06 & 0.08 & 0.08 & 0.08 & 0.05 & 0.10 & 0.07 & 0.06 & 0.06 & 0.09 & 0.07 & 0.06 & 0.03 & 0.02 & 0.04 & 0.10 & 0.10 & 0.10 & 0.13 & 0.12 \\
\hline Total & 7.37 & 7.24 & 7.22 & 7.20 & 7.26 & 7.26 & 7.34 & 7.19 & 7.20 & 7.40 & 7.27 & 7.15 & 7.40 & 7.47 & 7.43 & 7.35 & 7.37 & 7.37 & 7.24 & 7.24 \\
\hline
\end{tabular}


Tabela 6 - Resultado analítico de feldspato

\begin{tabular}{|c|c|c|c|c|c|c|c|c|c|c|}
\hline \multirow{3}{*}{$\begin{array}{c}\text { Rock type } \\
\text { Sample } \\
\text { Analysis (\%) }\end{array}$} & \multicolumn{3}{|c|}{ Hornblendite Type I } & \multicolumn{4}{|c|}{ Vrm - phlogopitite vein } & \multirow{2}{*}{\multicolumn{3}{|c|}{$\begin{array}{c}\text { Quartz - Feldspar Dyke } \\
\text { FS-151 17,7m }\end{array}$}} \\
\hline & \multicolumn{3}{|c|}{ AM20 } & \multicolumn{2}{|c|}{ FS17 - 28,65m } & \multicolumn{2}{|c|}{ AM21 } & & & \\
\hline & C4 92 & C4 94 & C2 113 & C3 19 & C3 20 & C2 23 & C2 24 & III CII 16 & III CI 21 & III CIV 5 \\
\hline $\mathrm{SiO}_{2}$ & 64.01 & 64.12 & 60.06 & 66.24 & 66.58 & 65.38 & 66.12 & 60.12 & 63.48 & 63.04 \\
\hline $\mathrm{TiO}_{2}$ & 0.00 & 0.00 & 0.17 & 0.00 & 0.00 & 0.05 & 0.00 & 0.04 & 0.14 & 0.00 \\
\hline $\mathrm{Al}_{2} \mathrm{O}_{3}$ & 21.01 & 21.13 & 23.45 & 19.87 & 19.98 & 21.17 & 20.47 & 19.30 & 22.18 & 18.78 \\
\hline $\mathrm{Cr}_{2} \mathrm{O}_{3}$ & 0.02 & 0.00 & 0.01 & 0.00 & 0.05 & 0.00 & 0.00 & 0.00 & 0.00 & 0.05 \\
\hline $\mathrm{FeO}_{\text {(total) }}$ & 0.00 & 0.02 & 0.11 & 0.06 & 0.07 & 0.04 & 0.05 & 0.02 & 0.00 & 0.02 \\
\hline $\mathrm{MnO}$ & 0.02 & 0.00 & 0.00 & 0.00 & 0.14 & 0.00 & 0.03 & 0.00 & 0.00 & 0.00 \\
\hline $\mathrm{MgO}$ & 0.00 & 0.03 & 0.00 & 0.00 & 0.00 & 0.02 & 0.00 & 0.00 & 0.00 & 0.00 \\
\hline $\mathrm{CaO}$ & 1.29 & 1.61 & 4.23 & 0.12 & 0.11 & 1.13 & 0.88 & 0.02 & 3.16 & 0.00 \\
\hline $\mathrm{Na}_{2} \mathrm{O}$ & 10.79 & 10.80 & 9.02 & 11.86 & 11.79 & 10.95 & 11.16 & 0.97 & 9.49 & 1.06 \\
\hline $\mathrm{K}_{2} \mathrm{O}$ & 0.07 & 0.07 & 0.10 & 0.05 & 0.01 & 0.07 & 0.08 & 13.29 & 0.15 & 14.57 \\
\hline $\mathrm{NiO}$ & 0.02 & 0.00 & 0.00 & 0.04 & 0.00 & 0.00 & 0.00 & 0.00 & 0.00 & 0.00 \\
\hline $\mathrm{BaO}$ & 0.01 & 0.00 & 0.09 & 0.00 & 0.08 & 0.02 & 0.05 & 5.13 & 0.02 & 2.01 \\
\hline $\mathrm{P}_{2} \mathrm{O}_{5}$ & 0.00 & 0.05 & 0.05 & 0.03 & 0.09 & 0.05 & 0.01 & 0.01 & 0.06 & 0.02 \\
\hline $\mathrm{SrO}$ & 0.15 & 0.22 & 0.51 & 0.01 & 0.19 & 0.16 & 0.33 & 0.51 & 0.28 & 0.08 \\
\hline $\mathrm{ZnO}$ & 0.00 & 0.00 & 0.01 & 0.00 & 0.00 & 0.00 & 0.12 & 0.00 & 0.02 & 0.11 \\
\hline $\mathrm{Cl}$ & 0.00 & 0.00 & 0.00 & 0.01 & 0.01 & 0.00 & 0.01 & 0.01 & 0.00 & 0.00 \\
\hline $\mathrm{F}$ & 0.06 & 0.15 & 0.09 & 0.11 & 0.12 & 0.12 & 0.01 & 0.00 & 0.00 & 0.00 \\
\hline Total & 97.42 & 98.12 & 97.88 & 98.36 & 99.16 & 99.12 & 99.31 & 99.42 & 98.98 & 99.74 \\
\hline \multicolumn{11}{|c|}{ number of ions on the base of 8 oxygens } \\
\hline $\mathrm{Si}$ & 2.88 & 2.86 & 2.72 & 2.93 & 2.93 & 2.89 & 2.92 & 2.89 & 2.84 & 2.95 \\
\hline $\mathrm{Ti}$ & 0.00 & 0.00 & 0.01 & 0.00 & 0.00 & 0.00 & 0.00 & 0.00 & 0.00 & 0.00 \\
\hline $\mathrm{Al}$ & 1.11 & 1.11 & 1.25 & 1.04 & 1.04 & 1.10 & 1.06 & 1.09 & 1.17 & 1.04 \\
\hline $\mathrm{Cr}$ & 0.00 & 0.00 & 0.00 & 0.00 & 0.00 & 0.00 & 0.00 & 0.00 & 0.00 & 0.00 \\
\hline $\mathrm{Fe}^{3+}$ & 0.00 & 0.00 & 0.00 & 0.00 & 0.00 & 0.00 & 0.00 & 0.00 & 0.00 & 0.00 \\
\hline $\mathrm{Fe}^{2+}$ & 0.00 & 0.00 & 0.00 & 0.00 & 0.00 & 0.00 & 0.00 & 0.00 & 0.00 & 0.00 \\
\hline $\mathrm{Mn}$ & 0.00 & 0.00 & 0.00 & 0.00 & 0.01 & 0.00 & 0.00 & 0.00 & 0.00 & 0.00 \\
\hline $\mathrm{Mg}$ & 0.00 & 0.00 & 0.00 & 0.00 & 0.00 & 0.00 & 0.00 & 0.00 & 0.00 & 0.00 \\
\hline $\mathrm{Ca}$ & 0.06 & 0.08 & 0.21 & 0.01 & 0.00 & 0.05 & 0.04 & 0.00 & 0.15 & 0.00 \\
\hline $\mathrm{Na}$ & 0.94 & 0.93 & 0.79 & 1.02 & 1.01 & 0.94 & 0.95 & 0.09 & 0.82 & 0.10 \\
\hline $\mathrm{K}$ & 0.00 & 0.00 & 0.01 & 0.00 & 0.00 & 0.00 & 0.00 & 0.81 & 0.01 & 0.87 \\
\hline $\mathrm{Ni}$ & 0.00 & 0.00 & 0.00 & 0.00 & 0.00 & 0.00 & 0.00 & 0.00 & 0.00 & 0.00 \\
\hline $\mathrm{Ba}$ & 0.00 & 0.00 & 0.00 & 0.00 & 0.00 & 0.00 & 0.00 & 0.10 & 0.00 & 0.04 \\
\hline Cations & 5.00 & 4.99 & 4.99 & 5.00 & 5.00 & 5.00 & 4.99 & 4.99 & 4.99 & 4.99 \\
\hline An & 6.16 & 7.59 & 20.43 & 0.55 & 0.49 & 5.39 & 4.17 & 0.11 & 15.41 & 0.00 \\
\hline $\mathrm{Ab}$ & 93.44 & 92.04 & 78.85 & 99.16 & 99.33 & 94.17 & 95.31 & 9.02 & 83.67 & 9.57 \\
\hline Or & 0.38 & 0.37 & 0.55 & 0.28 & 0.04 & 0.40 & 0.44 & 81.23 & 0.88 & 86.75 \\
\hline
\end{tabular}

